
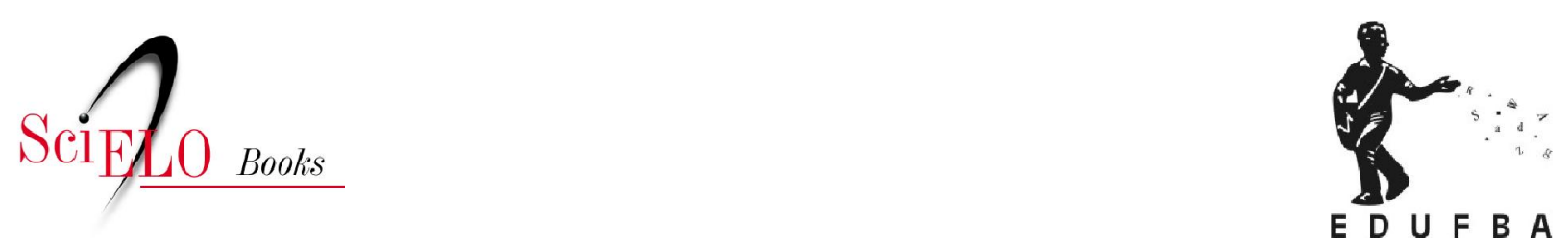

\title{
Artefatos digitais para mobilização da sociedade civil perspectivas para avanço da democracia
}

José Antonio G. de Pinho (org.)

PINHO, J.A.G., ed. Artefatos digitais para mobilização da sociedade civil: perspectivas para avanço da democracia [online]. Salvador: EDUFBA, 2016, 253 p. ISBN: 978-85-232-1877-5.

https://doi.org/10.7476/9788523218775.

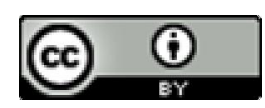

All the contents of this work, except where otherwise noted, is licensed under a Creative Commons Attribution $\underline{4.0 \text { International license. }}$

Todo o conteúdo deste trabalho, exceto quando houver ressalva, é publicado sob a licença Creative Commons Atribição 4.0.

Todo el contenido de esta obra, excepto donde se indique lo contrario, está bajo licencia de la licencia Creative Commons Reconocimento 4.0. 


\section{Artefatos Digitais para mobilização da Sociedade Civil}

perspectivas para avanço da democracia 
UNIVERSIDADE FEDERAL DA BAHIA

REITOR

João Carlos Salles Pires da Silva

VICE-REITOR

Paulo Cesar Miguez de Oliveira

ASSESSOR DO REITOR

Paulo Costa Lima

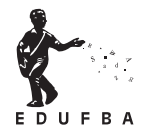

Editora dA Universidade FEderal dA BAHIA

DIRETORA

Flávia Goulart Mota Garcia Rosa

CONSELHO EDITORIAL

Alberto Brum Novaes

Angelo Szaniecki Perret Serpa

Caiuby Alves da Costa

Charbel Niño El-Hani

Cleise Furtado Mendes

Dante Eustachio Lucchesi Ramacciotti

Evelina de Carvalho Sá Hoisel

José Teixeira Cavalcante Filho

Maria Vidal de Negreiros Camargo 


\section{Artefatos Digitais para mobilização da Sociedade Civil}

perspectivas para avanço da democracia

José Antonio G. de Pinho ORGANIZADOR

Salvador | Edufba | 2016 
2016, Autores.

Feito o depósito legal.

Direitos para esta edição cedidos à Edufba.

Grafia atualizada conforme o Acordo Ortográfico da Língua Portuguesa de 1990, em vigor no Brasil desde 2009.

CAPA, PROJETO GRÁFICO E EDITORAÇÃo

Lúcia Valeska Sokolowicz

NORMALIZAÇÃO

Daniele Nascimento

REVISÃO

Mítian Fonseca

Sistema de Bibliotecas - UFBA

Artefatos digitais para mobilização da sociedade civil : perspectivas para avanço da democracia / José Antonio G.de Pinho, organizador. - Salvador : EDUFBA, 2016.

253 p. : il.

ISBN $978-85-232-1475-3$

1.Sociedade da informação - Aspectos políticos. 2. Internet - Aspectos políticos . 3. Internet Aspectos sociais. 4. Participação política - Recursos de redes de computadores. 5. Movimento de protestos. 6. Democracia. I. Pinho, José Antonio G. de.

Editora filiada à:

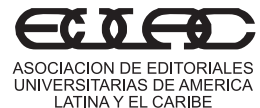
LATINA YEL CARIBE
LATIAS DE

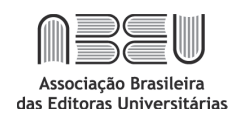

$\mathrm{CBaL}$

Câmara Bahiana do Livro

EDITORA DA UNIVERSIDADE FEDERAL DA BAHIA

Rua Barão de Jeremoabo s/n

Campus de Ondina - 40.170-115

Salvador - Bahia - Brasil

Telefax: 0055 (71) 3283-6160/6164

edufba@ufba.br -www.edufba.ufba.br 


\section{SUMÁRIO}

7 PREFÁCIO

13 APRESENTAÇÃO

17 MECANISMOS PARA A CONSTRUÇÃO DA

TRANSPARÊNCIA uma breve análise do caminho entre a democracia representativa e a democracia digital

ANA CLÁUDIA FARRANHA

37 COMUNICACIÓN GUBERNAMENTAL Y CONDICIONES DEL DIÁLOGO PÚBLICO

CORINA ECHAVARRÍA, CECÍLIA BRUSCOLI

73 EVOLUÇÃO DO USO DA INTERNET NA PARTICIPAÇÃO POLÍTICA DE ORGANIZAÇÕES DA SOCIEDADE CIVIL

JUSSARA BORGES, OTHON JAMBEIRO

99 ESTUDO DAS MUDANÇAS NOS PROCESSOS DE GESTÃO DE SISTEMAS DA INFORMAÇÃO PELA INCORPORAÇÃO DE ARTEFATOS DIGITAIS INTERATIVOS

LEILA LAGE HUMES, NICOLAU REINHARD

119 TRANSPARÊNCIA GOVERNAMENTAL ELETRÔNICA PARA ACCOUNTABILITY

MARIA ALEXANDRA CUNHA, MARCO ANTÔNIO CARVALHO TEIXEIRA, TAIANE RITTA COELHO, MARIA CAMILA FLORÊNCIO DA SILVA, STEFANIA LAPOLLA CANTONI

141 MOVIMENTO PASSE LIVRE E AS MANIFESTAÇÕES DE 2013 a internet nas Jornadas de Junho MAÍRA OURÍVEIS DO ESPÍRITO SANTO, EDUARDO HENRIQUE DINIZ, MANUELLA MAIA RIBEIRO

169 DOS VINTE RÉIS AOS VINTE CENTAVOS o papel das redes sociais e movimentos coletivos no Brasil JOSÉ ANTONIO GOMES DE PINHO, INGRID WINKLER, JÚLIO CÉSAR ANDRADE DE ABREU, FABIANO MAURY RAUPP

223 SERVIÇOS DE GOVERNO ELETRÔNICO um panorama do uso no Brasil ERNANI MARQUES DOS SANTOS, NICOLAU REINHARD

247 SOBRE OS AUTORES 


\section{PREFÁCIO}

Poucos eventos provocaram tanta comoção e chamaram tanta atenção no Brasil recentemente quanto as gigantescas manifestações de junho de 2013.

Já se passaram mais de dois anos e ainda continuamos a nos perguntar o que as provocou e o que delas permaneceu, ou seja, quais teriam sido suas determinações e que efeitos elas produziram na vida política do país.

Entre as inúmeras análises que surgiram com a intenção de responder a essas indagações, algum consenso se formou. As manifestações foram políticas, mas não seguiram nenhuma cartilha política e, sobretudo, buscaram novos caminhos para a ação política. Afastaramse de partidos e lideranças, chegando mesmo a se oporem abertamente a tudo o que pudesse sugerir vínculos com a política instituída. Não foram contra este ou aquele governo em particular, este ou aquele partido, mas contra todos. Não contra o Estado ou o mercado, mas a favor de um poder público que se voltasse para a sociedade e os cidadãos. Sua agenda não foi clara e nem bem estruturada, mas alguns pontos foram taxativamente centralizados: mobilidade urbana, mais voz para os jovens, fim da corrupção, mais e melhores políticas públicas. Não tiveram cor definida nem uma única palavra de ordem: foram multicoloridas, plurais, dinâmicas, móveis, espasmódicas. Valeram-se intensamente das tecnologias de informação e comunicação, das redes, dos celulares, de selfies e postagens-relâmpago. A própria mobilização não se fez segundo parâmetros conhecidos e, somente em aspectos 
secundários, puderam ser percebidos pontos de ligação com as manifestações dos anos 1960, com os comícios em favor das eleições diretas em 1984 ou com os "caras-pintadas" que pediram o impeachment de Fernando Collor em 1992.

Chegamos assim ao ponto de poder dizer: em junho de 2013, a hipermodernidade explodiu nas ruas brasileiras, exibindo seu estilo imprevisível, sua falta de "narrativa" sustentável, sua distância da política instituída, sua adesão às redes e ao uso intensivo das tecnologias de informação e comunicação, sua mobilização e movimentação horizontais.

As manifestações políticas de protesto e contestação adquiriram assim outra forma, outro ritmo, outra modulação, assim como novas pautas e novos protagonistas.

No vasto território da sociedade civil, algo semelhante já estava em marcha há mais tempo. A proliferação de organizações nãogovernamentais, o voluntariado, a ênfase empresarial na "responsabilidade social" e a busca de novos modos de participar na esfera pública haviam se sucedido com grande rapidez, a indicar no mínimo um aumento da fragmentação, da diferenciação e da complexidade social.

Por fim, pelo ângulo do Estado e do governo, ao menos desde os anos 1990 já se ouviam os ecos da modernidade capitalista que se radicalizava e se tornava mais tecnológica. As experiências de governo eletrônico e de "empowerment" da cidadania, assim como a reformulação dos processos de gestão e formatação de políticas, caminharam ao lado das tentativas de ampliar a participação na administração e no governo da sociedade. O orçamento participativo se seguiu à experiência dos conselhos setoriais balizada pela Constituição de 1988 .

Com os protestos de junho de 2013 , tornou-se evidente que o país mudara, que sua estrutura e sua estratificação acompanhavam o que se passava nas sociedades contemporâneas. Seu sistema político, porém, estacionara, deixando de dialogar com os cidadãos. A sociedade havia se tornado gradualmente mais dinâmica e mais diferenciada, com mais mobilidade social, novas culturas e novas expectativas. Passara a funcionar cada vez mais em rede. Os centros de poder entraram em crise, perderam transparência e força. O poder deixou de se concentrar exclu- 
sivamente no Palácio do Planalto ou em algum outro palácio: disseminou-se por vários centros e nichos, ainda que em escala e potência diferenciadas. Os partidos foram pesando cada vez menos na organização de consensos sociais. Era como se estivesse em marcha uma revolução sem revolução, a sociedade ultrapassando o sistema político e pondo em xeque o que estava instituído. O conflito social havia sido reconfigurado pela digitalização da vida e por modificações importantes ocorridas no mundo do trabalho.

Todo esse processo, que se articula com as modificações que se espalham pelo mundo do capitalismo global e da modernidade radicalizada, desceu às ruas de junho de 2013. As determinações dos protestos inscreveram-se não somente na história nacional e na conjuntura política mas também na realidade do capitalismo globalizado. E por mais que já tivessem sido dados sinais de que algo se mexia no subsolo, tudo veio à tona de uma só vez. Daí, talvez, a dificuldade para que se compreenda o que se passou.

Naquele mês emblemático, a hipermodernidade emergiu com tudo nas ruas. Trouxe consigo uma nova politicidade, à margem de partidos e organizações e repleta de tendências "niilistas" pré-políticas. Não faz sentido romantizar os protestos, vê-los como sendo o anúncio de uma democracia revitalizada e ignorar que eles foram uma "terra de ninguém”, aberta ao protagonismo genérico de muitos grupos e indivíduos. As vozes da revolta verbalizaram demandas reais, mas também muita intolerância e incompreensão. Disseram muitas coisas, mas não forneceram soluções. Despertaram consciências e tiraram a política da letargia, mas mostraram ter baixo poder de agenda e dificuldades para elaborar uma análise da situação e coordenar os próprios passos políticos. Mesmo assim, seu efeito positivo não pode ser desprezado.

Foi um efeito de longo prazo: a política e a gestão se viram forçadas a levar em conta a realidade viva das ruas, vê-las não mais como "estoque" de votos, como local de existência de massas que "falariam" em momentos eleitorais, mas como um dado permanente, um sujeito que pesa e determina muita coisa. Os governos encolheram a partir de então, com dificuldades para saber como reagir e o que fazer. Leva- 
ram consigo o sistema político, que se desarvorou e perdeu o eixo que, bem ou mal, o sustentara até então. A polarização cresceu, tornando a disputa política menos interessante, mais cansativa e mais distante do cotidiano popular. As ruas ficaram entregues à própria sorte, sem presença partidária, sem coordenação. Permaneceram ativas, como no ano de 2015 , fazendo sentir sua voz, ainda que sem um programa muito claro. Em parte, foram capturadas por discursos conservadores, mais à direita, mas em nenhum momento deixaram de expressar indignação, desejo de mudança e revolta contra a política instituída.

O livro que o leitor tem agora em mãos presta um serviço importante para que se compreendam as novas dimensões e os novos modos de ação política impulsionados pelo uso generalizado de "artefatos digitais" e tecnológicos (internet, redes sociais, celulares, blogs, sites, portais), que exercem forte poder de comando sobre a vida em seu todo e, portanto, sobre a mobilização da sociedade civil e as possibilidades de avanço e de qualificação da democracia. As reflexões feitas acima são contempladas pelos diversos artigos agrupados nesta obra. Se no caso do Brasil os movimentos de junho de 2013 saltam aos olhos, tornando-se um ponto de inflexão na luta política, agora também desempenhada na arena digital, o livro também traz uma contribuição que contempla a situação da Argentina. O artigo em tela se debruça sobre a implementação de orçamentos participativos (tema também caro à experiência brasileira) em três localidades examinando a questão-chave da comunicação no setor público, recorrendo ao referencial da democracia deliberativa. Como aqui, os processos também estão em construção e os resultados ainda não são animadores.

Elaborados de uma perspectiva plural metodologicamente consistente e buscando associar a reflexão mais teórica com estudos de caso pontuais, os artigos aqui reunidos compõem um conjunto que assume claramente a necessidade de se buscar a multiplicação dos focos e dos olhares para dar conta de um tema complexo e que não se deixa abraçar de uma só vez.

O projeto do livro é de extrema relevância: como escreve seu organizador, José Antonio Gomes de Pinho. Na introdução, os autores pretendem "estudar as possibilidades de utilização de artefatos digi- 
tais, com o propósito de avançar a democracia através do incremento da transparência, accountability e participação, configurando o que tem sido chamado de "democracia digital". Fornecem, com isso, um relevante elenco de temas e inflexões, que incluem as relações entre democracia representativa e democracia digital, a evolução do uso da internet na participação política e na atuação das organizações da sociedade civil, as mudanças nos processos de gestão e o efeito das redes sociais sobre os movimentos coletivos.

É um painel do mundo em que vivemos e, ao mesmo tempo, uma rica agenda de pesquisa, o que faz do presente livro uma iniciativa de destaque, que nos ajuda a continuar pensando criticamente e tentando compreender as sociedades atuais.

São Paulo, agosto de 2015

MARCO AURÉLIO NOGUEIRA

Professor Titular de Teoria Política e Diretor do Instituto de Políticas Públicas e Relações Internacionais-IPPRI da Universidade Estadual Paulista-UNESP, em São Paulo 


\section{APRESENTAÇÃO}

Não resta qualquer dúvida de que vivemos em uma sociedade digital permeada de artefatos tecnológicos que praticamente comandam a vida em seus múltiplos aspectos. Entendemos que estaríamos naquela fase de transição em que o "analógico" ainda está presente e desempenha papel relevante, mas sofre o "assédio" da área digital em vários campos da atividade humana. Um dos aspectos dessa digitalização do mundo reside na possibilidade do avanço da democracia, a partir do uso de artefatos digitais (internet, redes sociais, blogs, sites, portais, etc.). Os capítulos que formam este livro se agregam a partir do interesse de estudar as possibilidades de utilização de artefatos digitais, com o propósito de avançar a democracia através do incremento da transparência, accountability e participação, configurando o que tem sido chamado de democracia digital. Os artigos aqui reunidos trafegam tanto por aprofundamento de análises teóricas como por variados objetos empíricos. Assim, o primeiro capítulo, "Mecanismos para a construção da Transparência: uma breve análise do caminho entre a democracia representativa e a democracia digital", de autoria de Ana Cláudia Farranha, se detém na análise de redes sociais no sentido de observar os avanços da democracia on-line no Brasil, expressa pela ampliação do controle do cidadão e a busca da transparência. A autora parte da formulação clássica de Rousseau que defende a democracia direta e traz essa construção para o presente no qual estão presentes as tecnologias que podem (ou poderiam) propulsionar a democracia, através de mecanismos de participação popular. O artigo examina al- 
gumas iniciativas ocorridas no Brasil, mostrando avanços na área de informação, mas que, no entanto, não rompem a questão da participação nos processos decisórios. No segundo capítulo, "Comunicación gubernamental y condiciones del diálogo público”, as autoras, Corina Echavarria e Cecília Bruscoli, trazem a experiência da Argentina na implementação dos orçamentos participativos em três localidades, através de análise de portais municipais, destacando a centralidade da informação disponibilizada pelo setor público nos portais e a questão da participação dos cidadãos. As autoras ressaltam a falta de atenção à comunicação no setor público, baseando a análise no referencial da democracia deliberativa. Os autores do terceiro capítulo, "Evolução do uso da internet na participação política de organizações da sociedade civil", Jussara Borges e Othon Jambeiro, tomam a internet e as possibilidades que o artefato carrega de promover uma melhoria no funcionamento da democracia representativa através de ações políticas encaminhadas por Organizações da Sociedade Civil (OSC). Para tanto, examinam trinta organizações no lócus do estado da Bahia, extraindo a conclusão que as OSC analisadas apesar do avanço de uso das ferramentas digitais em anos recentes ainda combinam participação on-line e off-line. O quarto capítulo deste livro, "Estudo das Mudanças nos Processos de Gestão de Sistemas da Informação pela incorporação de Artefatos Digitais Interativos”, da lavra de Leila Lage Humes e Nicolau Reinhard, aporta um conhecimento sobre o uso de artefatos digitais e sua importância e centralidade no mundo contemporâneo, destacando aspectos culturais na absorção desses artefatos. Na percepção dos autores, vivemos em um mundo cada vez mais complexo onde também as interações representadas por emissores e receptores tornam-se mais complexas. O artigo deriva para uma análise preliminar de um sistema de saúde mostrando a aplicabilidade de artefatos digitais bem como apontam um longo caminho que se tem pela frente para o avanço desses artefatos. Os autores do quinto capítulo, Maria Alexandra Cunha, Marco Antonio Carvalho Teixeira, Taiane Ritta Coelho, Maria Camila Florêncio da Silva e Sefania Lapolla Cantoni, "Transparência governamental eletrônica para accountabili- 
ty", tratam da questão da transparência governamental como requisito básico para a accountability, fazendo uma varredura na teoria e nos conceitos de informação, transparência e accountability. O grupo de autores/as levantam aspectos positivos e negativos da transparência para a accountability e democracia. Em suma, os autores mostram que a transparência é uma etapa da accountability. O sexto capítulo, "Movimento Passe Livre e as manifestações de 2013: a internet nas Jornadas de Junho", de Maíra Ouriveis, Eduardo Henrique Diniz e Manuella Maia Ribeiro, aborda o Movimento Passe Livre (MPL), estudando a morfologia das manifestações, como elas vão se alterando e incorporando novos atores, bem como a centralidade do uso da internet nas manifestações onde os atores vão compartilhando informações. $\mathrm{O}$ artigo faz um histórico dos movimentos que levaram ao MPL a um caráter apartidário. Ao comentar a cronologia das jornadas, os autores mostram como vai mudando o posicionamento da mídia frente aos movimentos bem como dos governos estadual e municipal de São Paulo. O capítulo agrega valor ao debate ao "dar voz ao próprio MPL”, através de um de seus responsáveis, e nesse contexto, relativiza o papel da tecnologia, no caso a internet, no fomento de movimentos sociais. Os autores do sétimo capítulo, "Dos vinte réis aos vinte centavos: o papel das redes sociais movimentos coletivos no Brasil”, José Antonio G. de Pinho, Ingrid Winkler, Júlio César Abreu e Fabiano Maury Raupp, tomam como objeto de análise empírica três movimentos coletivos: a revolta do Vintém no final do Império, o movimento Fora Sarney de 2009, em Salvador, e as manifestações de junho de 2013, visando identificar quão longa é a luta pelo transporte público, que une o primeiro e o terceiro caso, e no caso dos dois últimos movimentos o uso de redes sociais para viabilização das manifestações. No caso do movimento Fora Sarney, a comunicação se dava ainda no âmbito do Orkut, valendo observar como os participantes tinham uma preocupação central da necessidade do movimento transbordar para a mídia tradicional, ser divulgado por esta, questão que ainda se coloca no presente apesar de todo o avanço e "independência" das atuais redes. Encerrando o projeto do livro, os autores do oitavo capítulo, 
"Serviços de Governo Eletrônico: um panorama do uso no Brasil”, Ernani Marques e Nicolau Reinhard, se voltam para a análise dos Serviços de Governo Eletrônico, traçando um panorama do uso no Brasil. Neste caso, é pertinente observar que os autores olham com cautela os dados observados, pois mesmo tendo importância inconteste a disponibilização de dados governamentais através do governo eletrônico, não existe uma correlação explícita da utilização desses dados pela população de forma generalizada.

Por último, vale ainda dizer que os pesquisadores aqui reunidos vêm de diversas e renomadas instituições brasileiras e internacionais, evitando, assim, a endogenia, trazendo diferenciados aportes teóricos e análises de objetos empíricos diversos. Este livro dá continuidade ao livro anterior publicado sobre a mesma temática, com o mesmo grupo original, com agregação de outros pesquisadores convidados, acreditando-se que pode contribuir para se constituir em material didático. O tema, como é sabido, é sincrônico e comporta vários olhares. O objetivo dos artigos aqui coligidos foi o de apresentar vários focos sobre o tema, ainda que sejam identificadas convergências entre os pensamentos dos autores.

JOSÉ ANTONIO GOMES DE PINHO

Professor Titular - Escola de Administração - UFBA 


\section{MECANISMOS PARA A CONSTRUÇÃO DA TRANSPARÊNCIA}

uma breve análise do caminho entre a democracia representativa e a democracia digital ${ }^{1}$

ANA CLÁUDIA FARRANHA

\section{INTRODUÇÃO}

As promessas não cumpridas da democracia - essa é uma frase que está presente em um dos livros muito conhecidos na Ciência Política, O Futuro da Democracia, de Norberto Bobbio. Nesse livro, o autor problematiza o tema enfatizando o porquê de a democracia ainda não ter sido completamente realizada no Estado Moderno. Assim, caminhos alternativos poderiam ser pensados como forma de realizar as promessas democráticas. A possibilidade de utilização de mecanismos mais diretos, combinados com a representação, segundo o autor, poderia ser uma saída para o impasse em questão. (BOBBIO, 1986, p. 52)

Passados 30 anos da primeira edição da obra (1984), tais promessas expressam a lógica de um formato de exercício de poder baseado na igualdade de procedimentos e condição ainda inconclusos. E, junto ao

1 Esse texto foi originalmente apresentado no VI Congresso CONSAD de Gestão Pública, ocorrido em Brasília, em 2013. 
não cumprimento dessas promessas, outros desafios se colocam diante do exercício do poder: a ampliação da transparência, a informação ao cidadão, a necessidade de decisões que envolvam maior compromisso de todos os participantes e a prestação de serviços de qualidade como forma, também, de efetivação de uma lógica de democracia, capaz de ampliar o controle sobre a ação do agente púbico e a participação do cidadão nos processos decisórios.

Partindo dessa perspectiva, o presente texto procura analisar, de maneira ainda exploratória, em que medida formatos de interação baseados na internet (web 2.0 e outros mecanismos) podem auxiliar no cumprimento tais promessas.

Em outras palavras, trata-se de tentar responder às questões propostas por Bobbio, considerando os novos formatos de interação com o cidadão. Para tanto, serão retomadas, brevemente, algumas considerações sobre a democracia direta, destacando as possibilidades que tal formato coloca para as questões da transparência e participação na atualidade.

$\mathrm{Na}$ sequência, apresentam-se elementos constitutivos da democracia on-line, discorrendo sobre o papel das redes sociais (Facebook e Twitter) e, por fim, identificam-se alguns dos desafios colocados para a Administração Pública nesse contexto. Como forma de balizar algumas das discussões propostas, as ideias contidas nele baseiam-se em resultados preliminares da pesquisa "A Administração Pública nas redes sociais: discutindo elementos acerca das novas formas de informação ao cidadão"(CNPq/UnB).

\section{UMA BREVE LEITURA DO CONCEITO DE DEMOCRACIA}

Buscar uma definição de democracia não é tarefa muito fácil diante da multiplicidade de formulações feitas em torno do conceito. Nesse sentido, esse capítulo escolheu trabalhar com a formulação rousseaniana, tendo em vista que ela ajuda a problematizar o tema proposto: ampliação da transparência e a participação e, ao mesmo tempo, retoma alguns conceitos, os quais influenciarão fortemente nos contornos 
da democracia contemporânea. Em outras palavras, é em Rousseau que identificamos os fundamentos da democracia direta, os quais, nos tempos atuais, ganham o contorno de democracia participativa.

A definição de democracia que Rousseau nos apresenta é a forma de governo na qual o povo tem o poder de legislar. Ao mesmo tempo, o povo assume o papel de executar as leis, pois se a vontade geral prevalece o povo estará submetido a si mesmo, conforme os requisitos estabelecidos para o pacto social. Por isso, inicialmente, a forma de democracia a que Rousseau adere é a democracia direta, visto que a vontade geral não pode ser representada: cabe, exclusivamente, ao povo a decisão sobre os assuntos da sociedade.

A aristocracia e a monarquia não permitem a participação direta do povo no processo político, pois, como o autor escreve, a primeira limita o poder político nas mãos de uma pequena parte da sociedade e a segunda concentra o poder de legislar, exclusivamente, nas mãos do monarca, de forma que nesses formatos de governo a vontade geral seria suprimida.

O governo, nessa abordagem, deveria ser apenas um "empregado" do povo, e todos os seus atos deveriam estar totalmente condicionados à aprovação da assembleia popular como forma de colocar a vontade geral acima das vontades particulares. A ideia de democracia direta defendida pelo autor resgata a democracia grega, trazendo a ideia do espaço público, ${ }^{2}$ de uma arena de debate ampla, que acolhe os interesses de toda a sociedade, isto é, ressalta a vontade geral como princípio norteador da vida política e social.

A democracia que Rousseau propõe, ou seja, aquela que coloca a vontade geral e a soberania popular acima dos interesses particulares, a que requer a constante aprovação do povo nas questões que regulamentariam a vida política e que não admite a representação da vontade

2 Nesse trabalho não será desenvolvida uma concepção mais esboçada de espaço público, mas trata-se de um conceito útil para a discussão proposta tendo em vista que o uso dele extrapola uma visão formalista da democracia, inserindo o debate democrático em uma vertente mais culturalista e capaz de engendrar novas práticas no exercício do poder político. Sobre isso, ver Arendt (1993), Fraser (1993) e Habermas (1987). 
geral, é a democracia direta. Ela dependeria de situações nas quais a igualdade não é só um procedimento formal, mas uma racionalidade capaz de dar ao "povo" (ou a todos) a condição de se autorrepresentar. (ROUSSEAU, 1973, p. 15) De alguma forma, atributos como o ser visto e ouvido e a autonomia da expressão subjazem a essa formulação.

Por outro lado, o autor estabelece rígidas críticas sobre a democracia representativa. Para Rousseau, esse modelo de governo não representa a vontade geral, mas a vontade de particulares pelo fato de instituir um parlamento que apenas acolhe os conflitos das diversas classes sociais. É um sistema que abre a esfera política para o conflito de interesses ao invés de concretizar a vontade popular, o que configura a alienação da vontade geral: o governo, que deveria ser um comissário do povo, passa a ser o titular da vontade geral.

Nada é mais perigoso que a influência dos interesses privados nos negócios públicos; e o abuso das leis por parte do governo constitui um mal menor que a corrupção por parte do legislador, continuação infalível dos alvos particulares. Então, alterado o Estado em sua substância, toda reforma se torna impossível. (ROUSSEAU, 1973, p. 73)

Essas formulações conduzem as conclusões a dois pontos. Primeiro, a proposta de democracia em Rousseau não se limita a uma forma de governo, mas vai além da esfera institucional, colocando-se como uma concepção de vida de caráter moral ao considerar o bem-comum superior ao benefício individual; a democracia deve ser entendida como um valor moral a ser universalizado na sociedade. E um segundo, que interessa a esse texto, a necessidade de que esse governo - titular de uma vontade geral - seja constantemente fiscalizado e acompanhado. O próprio Rousseau desacredita nessa possibilidade. ${ }^{3}$ Entretanto, para os dilemas contemporâneos da democracia, a lógica da vigilância e do

3 Há várias passagens do contrato social em que o autor afirma que a democracia, nesse formato, deveria se utilizada "se houvesse um povo de deuses". Entretanto, para os dilemas contemporâneos da democracia, a lógica da vigilância e do debate constante voltado para a construção da vontade geral (consenso) parece ser pertinente. 
debate constante voltado para a construção da vontade geral (consenso) parece ser pertinente.

Abrindo um lapso temporal entre a teoria política e as questões levantadas por Bobbio sobre o futuro da democracia, mencionadas no início desse texto, retoma-se alguns aspectos do debate sobre transparência. Assim, a partir das considerações de Rousseau, observa-se que o problema colocado para a efetivação da democracia refere-se ao controle, seja ele articulado do ponto de vista político (sobre a forma como se formam as posições) ou o administrativo (sobre a forma como se fiscaliza a ação do governo).

Nesse aspecto, o tema referente ao uso de novas Tecnologias da Informação e Comunicação (TICs) parece pertinente como propulsor de uma inovação do conceito de democracia. Para tanto, somase ao debate o conceito de accountability. Prado, Ribeiro e Diniz (2012, p. 16), discutindo as relações entre tecnologia, informação e democracia, apresentam a seguinte perspectiva para termo:

O debate teórico surgido nos últimos nos sobre accountabilitty está relacionado ao fato de as discussões sobre os conceitos terem sido colocadas na agenda pública em meado dos anos 1990, no contexto da segunda geração de reformas do Estado. Apesar do termo accountabilitty ser relativamente freqüente no debate internacional dos últimos anos, o termo não está precisamente definido na literatura $[\ldots]$.

Os autores continuam destacando que a Organização das Nações Unidas (ONU) define o termo como "agir com responsabilidade e de forma responsiva”. (PRADO; RIBEIRO; DINIZ, p. 16) Assim, apontam, com base nas terminologias adotadas pela United Nations Public Administration Network (UNPAN), aspectos da dimensão interna e externa do termo, as quais podem ser caracterizadas, no quadro 1, conforme segue: 
Quadro 1 - Dimensões da accountability

\begin{tabular}{|c|c|}
\hline DIMENSÃO & CARACTERÍSTICAS \\
\hline Interna & $\begin{array}{l}\text { Essa dimensão é caracterizada pelas ações/decisões dos agentes } \\
\text { (servidores) nas esferas gerencial, legal, profissional, política e } \\
\text { financeira que afetam a totalidade da organização. Essas ações } \\
\text { definições têm repercussões externas e podem, também, ser alvo } \\
\text { de interface dos servidores com outras esferas do poder público. }\end{array}$ \\
\hline Externa & $\begin{array}{l}\text { Refere-se àquele controle exercido "por fora". } \\
\text { Trata-se da repercussão da ação interna nas diferentes esferas para } \\
\text { as quais ela é dirigida. Accountability política, ligando o servidor às } \\
\text { esferas de legitimação da política (Poder Legislativo); accountability } \\
\text { legal, relativa à ação ligada ao sistema legal, obediências aos } \\
\text { procedimentos normativos (Poder Judiciário); a accountability } \\
\text { financeira, relacionada aos processos de financiamento e, } \\
\text { accountability pública, relacionada aos cidadãos em geral. }\end{array}$ \\
\hline
\end{tabular}

Fonte: elaborado pela autora com base em Prado, Ribeiro e Diniz (2012) e Heeks (1998). ${ }^{4}$

Essa caracterização é importante para a análise proposta, pois ela possibilita compreender em que medida o tema da democracia direta se recoloca no espaço da Administração Pública, como ele está ligado à perspectiva do controle, principalmente, o controle externo das ações dos servidores e, como a possibilidade de efetivar essas promessas não cumpridas da democracia, de alguma forma, estão presentes no uso de tecnologias da informação como mecanismos que se propõem à maior eficácia e efetividade, capazes de ampliar a participação do cidadão. Sob essa perspectiva, uma questão a ser levantada é: seria a democracia on-line um caminho possível? Essa é a discussão do próximo item.

\section{DEMOCRACIA ON-LINE: POSSIBILIDADES DE UM ESPAÇO DE MAIOR PARTICIPAÇÃO ?}

Se a lógica proposta por Rousseau é de uma democracia direta, viva e motivada pela participação do cidadão, ainda que ao longo de suas formulações ele mesmo desacredite dessa existência, o desenvolvimento do estado democrático mostrou-se mais afinado com uma perspectiva que incentiva a técnica nos processos decisórios (daí a expressão "promessas não cumpridas”).

4 Para uma compreensão mais detalhada dessa discussão, recomenda-se um exame dos textos citados, pois eles contêm uma figura que define com mais exatidão a discussão proposta. 
Entretanto, os anos 1990, caracterizados como os anos da Reforma do Estado, trazem um conjunto de novos procedimentos, dentre os quais a possibilidade do uso da internet como forma de garantir maior acesso ao cidadão, divulgação da informação, desburocratização dos serviços e, em alguma medida, a intenção de construir mecanismos de consulta e participação, os quais deveriam proporcionar maior interação, controle, atuação e debate público constituindo um formato de democracia que vem sendo chamado de "democracia digital".

Muitos são os trabalhos que discutem esse conceito. (DAHLBERG, 2005; DI MAGGIO et al. 2001; HAMLETT, 2003; MOSCO; FOSTER, 2001) Para esse trabalho, escolheu-se a abordagem trazida por Echavarría (2012, p. 69, tradução nossa), a autora aponta que trata-se de uma "complementação da democracia representativa, tomando como base o uso de mecanismos de participação, com poder de decisão e controle da ação pública, mediados pelo tecnologia da informação." Entretanto, a autora adverte que "qualquer outra oportunidade de interação articulada pelas TICs, cujo vínculo se estabeleça entre os cidadãos com a gestão deveria ser considerada 'somente' governo eletrônico." 5

A discussão proposta pela autora segue destacando as diferenças entre os serviços voltados para gestão e aqueles dirigidos à decisão política. Assim, afirma:

A 'àgora eletrônica' se define como o âmbito da participação política que, de maneira inicialmente, complementar e potencialmente transformadora dos espaços tradicionais de participação, seria definida pelos espaços deliberativos criados e/ ou articulados com a incorporação das TICs. ${ }^{6}$ (ECHAVARRÍA, 2012, p. 69)

5 "Consideramos que el desarrollo de la "democracia electrónica" o digital se refiere, en principio, a una complemntación de la democracia representativa a través de la inclusión tecnológica de mecanismos participativos con poder de decisión de la ciudadanía y de control efectivo sobre la acción pública. Adviertiendo que cualquier otra oportunidad de interacción mediada por las TIC en el vínculo de los ciudadanos con la géstion pública debería ser considerada ‘solamente' gobierno electrónico.” (ECHAVARRÍA, 2012, p. 69)

6 El 'ágora eletrónica' se define como el ambito de la participación política que, de manera inicialmente complementaria y potencialmente transformadora de los espacios tradicionales 
Esse fragmento demonstra duas perspectivas em torno da democracia on-line. Uma que a autora considera complementar à democracia representativa e capaz de ampliar a possibilidade de informação do cidadão e, outra, considerada forte (fuerte), articulando mais amplamente o potencial transformador das TICs para as instituições democráticas. Buscando reproduzir essas ideias, apresenta-se o quadro abaixo.

Quadro 2 - Visões sobre a democracia on-line

\begin{tabular}{|ll|}
\hline Perspectiva & Enfatiza a dinamização e flexibilização das formas de \\
complementar(débil) & representação política, destacando maior aproximação entre \\
& representantes e representados, por meio das tecnologias da \\
& informação. Assim, a democracia seria mais que um método \\
& de seleção e autorização de "representantes fiduciários", \\
& isto é, aproximando os eleitores através da circulação de \\
& informação sobre os processos de tomada de decisão \\
& (por exemplo, transmissão completa dos debate nas casas \\
& legislativas) e aumentando, consequentemente, os momentos \\
& de prestação de contas (responsabilização) dos representantes \\
& na generalização da informação e não somente nos \\
& momentos eleitorais. Nessa visão, os eleitores se tornam mais \\
& autônomos, uma vez que há uma multiplicação dos fluxos \\
& de comunicação, possibilitando aos cidadãos ativos - que \\
& buscam informação - mais acesso às opiniões encontradas e \\
& que se manifestam nos distintos meios de comunicação. \\
Essa visão potencializa a capacidade transformadora da & tecnologia ao afirmar que ela maximiza e oportuniza a \\
comunicação política ao libertá-la da medicação (tradicional da \\
democracia representativa). Essa perspectiva considera que a \\
tecnologia oferece uma oportunidade para a "operatividade" \\
do poder democrático, tanto em termos agregativos como \\
deliberativos. Isto é, permitiria a integração da titularidade \\
e exercício do poder parte dos cidadãos, em formatos que \\
reforçam a presença imediata da cidadania em todas as esferas \\
da vida pública (voto eletrônico, sondagens instantâneas \\
sobre temas da cidadania) ou em desenhos que procuram \\
a concretização de um debate público vinculante (foros, \\
comunidades virtuais, etc.) \\
\hline forte
\end{tabular}

Fonte: Echavarria (2012, p. 70).

Essas visões não esgotam as discussões sobre o sentido de democracia on-line, mas mostram que há diferentes formas de promover

de participación, quedaria definido por los espacios deliberativos creados y/ o apoyados com la incorporación de las TIC's. (ECHAVARRÍA, 2012, p. 69) 
maior acesso do cidadão à informação, ao debate público e a formas de escolha e decisão política, mediadas pela tecnologia. Entretanto, que tipos de procedimentos, voltados à transparência, essas experiências colocam? É a democracia on-line um espaço para aprofundamento das questões públicas? Ainda que não seja objetivo desse artigo responder a essas questões, pode-se mencionar algumas experiências acerca desse formato. São elas:

I. Gabinete Digital: Trata-se de uma experiência desenvolvida pelo Governo do Rio Grande do Sul, criada em 2011, com objetivo de incorporar novas ferramentas de participação, oferecendo diferentes oportunidades ao cidadão de influenciar a gestão pública e exercer maior controle social sob o Estado. (RIO GRANDE DO SUL, 2013) Sua criação pautou-se em exemplos de democracia digital do Brasil e do exterior.

2. Orçamento Participativo Digital (Prefeitura de Belo Horizonte): Criado em 2006, com objetivo de ampliar a participação dos cidadãos no processo de deliberação do Orçamento Participativo Municipal, priorizando a escolha de investimentos. Naquele ano, foram escolhidas nove obras que seriam prioritárias. Essa escolha se deu pela internet, tendo a participação de 172.938 eleitores, cujos votos somaram 503 mil. ${ }^{7}$

3. E-democracia - Câmara dos Deputados: Trata-se de uma iniciativa desenvolvida no âmbito da Câmara dos Deputados, cuja proposta é, por meio da internet, incentivar a participação da sociedade no debate de temas importantes para o país. Para tanto, há dois tipos de participação: as comunidades legislativas e o espaço livre. Nas comunidades, a discussão volta-se para temas referentes a projetos de lei já existentes, oferecendo não somente o espaço de discussão, mas trazendo a perspectiva de informar ao cidadão a respeito do andamento da matéria no Congresso Nacional. O espaço livre funciona como uma tribuna, onde temas podem ser pautados e virem a se-tornar objetos das comunidades legislativas. (BRASIL, 2013)

7 Sobre isso ver Sampaio e colaboradores (2010) e Belo Horizonte (2008). 
Há uma série de outros exemplos (cidades digitais, fóruns de discussão, etc.), que poderiam ser citados, entretanto a menção a essas experiências ajuda a compreender as diferentes possibilidades em torno da democracia on-line, e, principalmente, remete a construção de um espaço de discussão e debate, que pode não levar, necessariamente, à tomada de decisões mais partilhadas, mas traz para o lugar público, aspectos que norteiam as questões políticas da sociedade brasileira.

A esses espaços adiciona-se a existência de fanpages e comunidades de órgãos da Administração Pública nas redes sociais, principalmente, Facebook e Twitter. Importante informar que existente basicamente três formatos de interação no Facebook: os perfis, cujo objetivo é estabelecer a interface entre usuários comuns, sendo utilizado por pessoas e não por organizações. A fanpage destina-se a organizações, pois vai mais além do perfil pessoal, destinado a amizades e estabelecendo relacionamentos que promovem a organização, informam sobre suas ações e criam um espaço de fidelização para seus "fans". As comunidades são grupos de discussão constituídos por usuários interessados em temas e debates específicos.

No caso da Administração Pública Federal, primeiramente foram estabelecidos perfis e, mais recentemente tais perfis foram transformados em fanpages. Conforme levantamento feito em fevereiro de 2013 , existem 18 fanpages de Ministérios do Governo Federal, cujo interesse em compreendê-los é identificar em que medida a presença destes órgãos auxilia no processo de transparência das ações públicas - cumprindo algumas das promessas da democracia.

Um aspecto importante dessa compreensão é retomar o conceito de rede, desenvolvido a partir de uma análise da teoria social, destacando as características e potenciais desse formato.

REDES SOCIAIS, DEMOCRACIA E TRANSPARÊNCIA:

PROBLEMAS E QUESTÕES ANALÍTICAS

A noção de rede está presente na discussão proposta por Castells (1999). Analisando o crescimento das novas formas de interação social, mediadas pela perspectiva da revolução informacional, o autor destaca que a 
metáfora da rede insinua uma situação na qual as interconexões se dão em nós, através dos quais vários cabos se ligam.

Nas redes sociais, organizacionais ou interpessoais estabelecem-se canais de relações entre diferentes elementos. Tais redes podem ser definidas, primeiramente, pela natureza de seus elementos (pessoas, organizações, etc.), pela natureza dos canais de conexão; e pela natureza das transações que ocorrem nesses canais. Em segundo lugar, as redes podem ser caracterizadas pelo seu alcance, complexidade, estabilidade, grau de homogeneidade e flexibilidade. Isso levaria a novas possibilidades de interação entre Estado e sociedade civil, cabendo a esta uma parcela, cada vez maior, de responsabilidade, seja no que se refere à elaboração e concepção das políticas, ou de sua gestão.

Assim, a informação se constitui em um importante instrumento de poder e de operacionalização dos canais desse Estado. Castells (1999, v. 1, p. 498) destaca que

Redes são estruturas abertas capazes de expandir de forma ilimitada, integrando novos nós desde que consigam comunicar-se dentro da rede, ou seja, desde que consigam compartilhar os mesmos códigos de comunicação (por exemplo, valores ou objetivos de desempenho). Uma estrutura social com base em redes é um sistema aberto altamente dinâmico suscetível de inovação sem ameaças ao seu equilíbrio. Redes são instrumentos apropriados para a economia capitalista baseada na inovação, globalização e concentração descentralizada; para o trabalho, trabalhadores e empresas voltadas para a flexibilidade e adaptabilidade para uma cultura de desconstrução e reconstrução contínua; para uma política destinada ao processamento instantâneo de novos valores humanos públicos; e para uma organização social que vise a suplantação do espaço e invalidação do tempo.

Observa-se que as redes trazem para a discussão da teoria social um novo formato de relações e interações econômicas, políticas e sociais, possibilitando maior descentralização, flexibilidade - e quem sabe - democracia. 
Buscando desnaturalizar o sentido do referido conceito e, em alguma perspectiva, divergido de Castells, Acioli (2007, p. 2) concorda que o sentido de rede envolve dinamicidade e rearranja elementos do tecido social. Destaca, assim, a seguinte perspectiva do conceito:

O termo rede sugere ainda fluxo, movimento, indicando uma aproximação com as mais variadas áreas de conhecimento conforme apontamos inicialmente. Em Ciências Sociais, rede seria o conjunto de relações sociais entre um conjunto de atores e também entre os próprios atores. Designa, ainda, os movimentos pouco institucionalizados, reunindo indivíduos ou grupos numa associação cujos limites são variáveis e sujeitos a reinterpretações. ${ }^{8}$

Entretanto, ao mesmo tempo em que a literatura aponta, nas redes, aspectos inovadores e de releitura da sociedade contemporânea, problematiza-se os resultados dessa interação. E, em particular, o Estado - nação, que na sua construção e articulação de poder passa a ser apontado como um caso de contradições resultantes da sociedade em rede. Castells, analisa os aspectos que se referem à crise do Estado-nação e as possibilidades que se colocam para sua ação, num momento em que este parece estar destituído de poder. Sua tese central é a de que, no contexto atual, há

A tentativa de o Estado reafirmar seu poder na arena global pelo desenvolvimento de instituições supranacionais acaba comprometendo ainda mais sua soberania. E os esforços do Estado para restaurar sua legitimidade por meio da descentralização do poder administrativo, delegando-o às esferas regionais e locais, estimulam as tendências centrífugas ao trazer os cidadãos para a órbita do governo, aumentando, porém a indiferença em relação ao Estado-Nação. (CASTELLS, 1999, v. 2, p. 287)

Os elementos de que parte Castells estão relacionados com o fato de que o contexto atual é marcado por um processo de globalização, de

8 As ideias apresentadas pela autora baseiam-se no argumento de Colonous (1995). 
uma economia que tende a se estruturar a partir de um elevado grau de interdependência, o que lhe confere um caráter de rede. E a questão que nos coloca é: como a possibilidade de funcionamento em rede pode ser verificada no Estado-nação? Seu argumento é que, embora o Estado-nação tenha perdido seu poder no que se refere à regulação econômica, na verdade, ele continua a deter certo poderio no que se refere à regulação das políticas sociais, ao mesmo tempo, mostra como as empresas que agem transnacionalmente vão se colocar numa posição de defesa em relação aos benefícios e a legislação social vigente em muitos destes países. (CASTELLS, 1999, v. 1)

O autor identifica um conjunto de ações deste Estado, no sentido de descentralizar o poder e reparti-lo com agências locais e regionais de elaboração de políticas públicas. Entretanto, para Castells esta perspectiva assinala elementos acerca de uma crise de legitimidade deste Estadoque, ao mesmo tempo em que delega poderes, não é capaz de se articular a partir desta delegação. Em outras palavras, embora o modelo se volte para aspectos da descentralização, o resultado dele é absolutamente imprevisível, o que leva o autor a afirmar que

Para superar tal crise de legitimação, os Estados descentralizam parte de seu poder em favor de instituições políticas locais e regionais. Essa transferência de poder decorre de duas tendências convergentes. De um lado, dada a diferenciação territorial entre as instituições do Estado, as identidades das minorias regionais e nacionais conseguem se manifestar com maior desenvoltura em níveis local e regional. Por outro lado, os governos nacionais tendem a concentrar-se na administração dos desafios impostos pela globalização da riqueza, da comunicação e do poder, permitindo, portanto que escalões inferiores do governo assumam a responsabilidade pelas relações com a sociedade tratando das questões do dia-a-dia, com o objetivo de reconstruir sua legitimidade por meio da descentralização do poder. Contudo, uma vez instaurado tal processo de descentralização, os governos locais e regionais podem tomar iniciativas em nome de suas respectivas populações, e até mesmo elaborar estratégias de desenvolvimento distintas do sistema global, o 
que faz com que concorram diretamente com seus próprios Estados centrais. (CASTELLS, 1999, v. 1, p. 319)

Acioli (2007) chama a atenção para fragmentação existente em um mundo articulado a partir de redes, e alerta para a necessidade de que o global e local sejam rearticulados em uma nova produção de sentido. Destaca que

Podemos, portanto pensar que nesse mundo em redes, onde há mais quantidade do que qualidade de informação, a possibilidade de fragmentação de saberes e culturas, e, portanto de sujeitos é muito grande Nesse sentido, o entrelaçamento entre o local e o global torna-se uma reorganização do tempo e do espaço que pode como diria Giddens, dissolver o sujeito num mundo de signos sem centro. Daí a necessidade de pensar o local e o global de modo articulado, com também as várias formas de valorização dos espaços internos - entendidos como os espaços locais. (ACIOLI, 2007, p. 10-11)

Considerando as discussões desenvolvidas até esse ponto, a perspectiva de que a rede descentraliza e ao mesmo tempo fragmenta, colocando como desafio uma nova articulação do Estado desde a perspectiva global até o nível local, é útil para compreender o sentido da informação existente nas fanpages dos Ministérios, pois auxilia a pensar qual perspectiva se coloca a partir dessa ação. Questiona-se, assim, se não se trata de um novo formato de interação com o cidadão, proporcionando mais transparência, publicidade e democracia na gestão desse Estado

\section{Papel de Facebook e Twitter nesse contexto}

As mudanças na gestão do Estado resultantes do processo de reformas dos anos 1990 trouxeram como uma das ferramentas centrais o uso da internet. Esse processo segue diferentes fases e chega à primeira década dos anos 2000, agregando um tipo de ferramenta denominado Web 2.0, a qual designa uma segunda geração de comunidades e serviços baseados na plataforma Web, como wikis e aplicações baseadas em redes sociais. Embora o termo tenha uma conotação de uma nova 
versão para a web, ele não se refere à atualização nas suas especificações técnicas, mas a uma mudança na forma como ela é encarada por usuários e desenvolvedores, ampliando a possibilidade de interação.

Morais (2010, p. 74) aponta que esse formato pode ser compreendido como

A web 2.0 pode ser vista, desse modo, um conjunto de ferramentas aptas a serem apropriadas de modo a favorecer construções coletivas, e facultando a cada usuário liberdade na maneira como interage nesses espaços. Pode ser de modo visto como mais tradicional, navegando entre os conteúdos, ou de forma mais ativa, criando e colaborando para a difusão de conteúdos que venham de alguma forma agregar àqueles sujeitos, bem como orientando suas próprias escolhas.

Nesse contexto, a autora observa a relevância que vem sendo dada por parte dos governos às redes sociais e aponta, a partir de Chang e Kannan (2008, p. 75), alguns aspectos desse uso, a saber:

[...] esse posicionamento governamental pode ser posto em prática baseado em três formas de uso distintas: foco na comunicação com a sociedade, no sentido de divulgar as ações governamentais; foco na interatividade, buscando um feedba$c k$ dos cidadãos sobre as políticas, serviços e ações do Governo; foco nos serviços, disponibilizando pela web 2.0 serviços públicos oferecidos por outros canais de relacionamento entre Estado e sociedade, aumentando a confiança dos cidadãos nas relações virtuais com o governo.

Juntamente a essa perspectiva, o Relatório Anual sobre o Jornalismo Americano (Annual Report on American Journalism), de 2012, destaca o crescimento das mídias sociais e seu potencial para notícia ao longo do ano de 2011, assinalando a importância do Facebook e do Twitter como divulgadores de notícias e informações. No caso americano, o Twitter aparece como a mídia social que os jornalistas mais consultam para obter notícias e informações (27\%), enquanto o Facebook tem um percentual menor (13\%) de consulta por esse público, sendo mais utilizado por amigos e parentes (70\%). 
O Relatório demonstra que Facebook e Twitter são na atualidade caminhos para informação, pois ainda que eles não envolvam a totalidade da população, ${ }^{9}$ aqueles que usam essas mídias o fazem, pois essa é uma nova forma de acessar a notícia e a informação. Isso demonstra que as mídias sociais são padrões adicionais, diferenciando-se da perspectiva tradicional da comunicação.

Essas perspectivas que assinalam essas mídias se apresentam como formas de comunicação nas quais a Administração Púbica pode se aproximar dos cidadãos, divulgar sua ação e construir um espaço que podemos denominar de discussão pública (espaço público). Ainda que essas ferramentas não se proponham à dimensão decisória da política, elas contêm elementos que podem ressignificar esse espaço, ampliando a interação sobre temas de interesse da sociedade.

Assim, pode-se afirmar que, do ponto de vista analítico, a compreensão do uso que a Administração Pública faz desses espaços possibilita identificar em que medida eles são capazes de fortalecer uma cultura cívica, capaz de promover discussões em torno de questões importantes que atravessam a sociedade brasileira.

A noção de espaço público a ser retomada refere-se àquela proposta por Habermas, cuja perspectiva é a de que a democracia, nesse caso, é constituída a partir de publicização do conflito e de reconhecimento de diferentes posições, as quais na arena pública possibilitam um tipo de articulação em torno do interesse público, quepode levar ao consenso e a construção de novas regras e visões em torno de res pública. Para encerrar, pode-se perguntar: serão as mídias sociais capazes de promover a construção de uma vontade geral?

\section{CONSIDERAÇÕES FINAIS: DESAFIOS PARA ADMINISTRAÇÃO PÚBLICA}

Esse texto norteou-se pela seguinte questão central: em que medida as transformações na forma de construção da democracia ampliam o controle do cidadão e possibilitam a transparência? Tratou-se de uma refle-

9 Aqui cabe um debate importante sobre a perspectiva de acesso às tecnologias da informação e aos requisitos (alfabetização, domínio de habilidades) necessários ao seu uso. Sobre isso ver Comitê Gestor da Internet no Brasil (2012) e Morais (2010). 
xão analítica baseada em conceitos e posições destacadas na literatura. Assim, partiu-se de uma discussão proposta por Rousseau acerca da democracia direta, desenvolvendo elementos que denotam o crescimento das mídias sociais no contexto atual e problematizam aspectos relativos à democracia, transparência e participação.

Preliminarmente, uma resposta provisória à questão levantada é que as mídias não podem ser tratadas como a grande descoberta do século. Elas têm um papel importante na construção de uma esfera pública com mais informação para o cidadão e como espaço de aprofundamento de discussões. Nesse aspecto, um dos primeiros resultados da pesquisa mencionada acima mostra que muitos posts colocados no perfil da Secretaria Especial de Igualdade Racial (Seppir) demonstram abertura para abordar a dimensão do racismo e das recentes políticas governamentais para a promoção da igualdade racial. ${ }^{\perp \circ}$

Como desafio para essa questão, pode-se afirmar que o papel da Administração Pública ao divulgar suas informações deve ir além de uma estratégia para a sua promoção, mas deve considerar a perspectiva que as redes sociais colocam para o fortalecimento desse espaço como um espaço de debate, que nas democracias modernas caracterizam-se não somente pelo resultado, mas, essencialmente pela forma como esse resultado é construído, revisitando, dessa forma, algumas das promessas não cumpridas da democracia.

\section{REFERÊNCIAS}

ACIOLI, S. Redes sociais e teoria social: revendo os fundamentos do conceito. Informação e Informação. Londrina, v. 12, n. esp., p. 8-19, 2007. Disponível em: <http://www.uel.br/revistas/uel/index.php/informacao/ article/view/1784/1520>. Acesso em: 15 jul. 2011.

ARENDT, H. A condição humana. Rio de Janeiro: Forense Universitária, 1993 .

BELO HORIZONTE (MG). Prefeitura. OP Digital 2008. Disponível em: $<$ http://opdigital.pbh.gov.br/>. Acesso em: 1 mar. 2013.

10 Informação colhida em entrevista realizada em fevereiro/2013 com a Coordenadora de Comunicação da Seppir. 
BOBBIO, N. O futuro da democracia: uma defesa das regras do jogo. 2. ed. Rio de Janeiro: Paz e Terra, I986.

BRASIL. Congresso Nacional. Câmara dos Deputados. E-democracia: participação virtual, cidadania real. Disponível em: $<$ http://edemocracia. camara.gov.br/>. Acesso em: 01 mar. 2013.

CASTELLS, Manuel. A sociedade em rede. São Paulo: Paz e Terra, I999. (A era da informacão: economia, sociedade e cultura; I).

CASTELLS, M. Um Estado destituído de poder? In: CASTELLS, M. O poder da identidade. São Paulo: Paz e Terra, 1999. Cap. 5, p. 319. (A era da informação: economia, sociedade e cultura; 2).

COMITÊ GESTOR DA INTERNET NO BRASIL. Pesquisa sobre o uso das tecnologias de informação e comunicação no Brasil: TIC domicílios e TIC empresas. São Paulo: Comitê Gestor da Internet no Brasil, 2012. Disponível em: <http://op.ceptro.br/cgi-bin/cetic/tic-domicilios-eempresas-2011.pdf>. Acesso em: 20 mar. 2013.

DAHLBERG, L. The Corporate Colonization of Online Attention and the Marginalization of Critical Communication? Journal of Communication Inquiry, v. 29, n. 2, p. 160-180, Apr. 2005.

DI MAGGIO, P. L. et al. Social implications of the Internet. Annual Review of Sociology, v. 27, p. 307-336, Aug. 2001.

DINIZ, E.; RIBEIRO, M. M.; PRADO, O. Governo eletrônico e transparência: olhar crítico sobre os portais do governo federal brasileiro. In: PINHO, J. A. G. de. (Org.). Estado, sociedade e interações digitais: expectativas democráticas. Salvador: Edufba, 2012.

ECHAVARRÍA, C. El Camino de la democracia digital: panorama em clave deliberativa de los sítios web desarrollados por los municípios cordobeses. In: PINHO, J. A. G. de. (Org.). Estado, sociedade e interações digitais: expectativas democráticas. Salvador: Edufba, 2012.

FRASER, N. Rethinking the Public Sphere: A Contribuition to the Critique of Actually Existing Democracy. In: BRUCE, R (Org.).

The Phantom Public Sphere. Mineápolis: University of Minnesota Press, 1993.

HABERMAS, J. A nova intransparência. Novos Estudos CEBRAP, São Paulo, n. 18, 1987. 
HAMLETT, P. W. Technology Theory and Deliberative Democracy. Science, Technology \& Human Values, v. 28, n. 1, p. 112-140, Jan. 2003.

HEEKS, R.B. Information systems and public sector accountability. Manchester, UK: Institute for Development Policy and Management, 1998. (Working Paper Series; n. 1) Disponível em: http:www.sed. manchester.ac.uk/idpm/reasearch/publications/wp/igoverment/igov_ wpor.htm>. Acesso em: 28 fev. 2013.

JORDAN, T. Language and Libertarianism: The Politics of Cyberculture and the Culture of Cyberpolitics. Sociological Review, v. 49, n. 1, 2001, p. 1-17.

MORAIS, K. S. Mídias Sociais e a Participação Política em Ambiente Digital no Brasil: estudos de caso no governo federal. 2010. Dissertação (Mestre em Administração) - Programa de Pós-Graduação em Administração, Escola de Administração, Universidade Federal da Bahia, Salvador, 2010.

MOSCO, V.; FOSTER, D. Cyberspace and the End of Politics. Journal of Communication Inquiry, v. 25, n. 3, 2001, p. 218-236.

PEW RESEARCH CENTER. The State of News Midias: An Annual Report on American Journalism. 2013. Disponível em http://www. stateofthemedia.org/files/2013/o8/SOTNM-low-rez-pdf.pdf. Acesso em: 10 nov. 2015 .

RIO GRANDE DO SUL. Gabinete Digital. O que é? Disponível em: <http://gabinetedigital.rs.gov.br/\#sobre>. Acesso em: 1 mar. 2013.

ROUSSEAU, J. J. O Contrato social e outros escritos. 4. ed. São Paulo: Cultrix, 1973.

SAMPAIO, R.; MAIA, R.; MARQUES, F. Participação e deliberação na internet: um estudo de caso do Orçamento Participativo Digital de Belo Horizonte. Opinião Pública, Campinas, v. 16, n. 2, p. 446-477, nov. 2010. 


\section{COMUNICACIÓN GUBERNAMENTAL Y CONDICIONES DEL DIÁLOGO PÚBLICO'}

CORINA ECHAVARRÍA, CECÍLIA BRUSCOLI

\section{INTRODUCCIÓN}

El estudio de la comunicación política es una tarea relativamente dificultosa por dos razones principales, porque en principio es todavía un concepto en disputa y porque los límites entre una rama y otra dentro del espacio de la comunicación política son difusos. (Cf. ARANCIBIA CARRIZO, 2000) Tanto que es posible distinguir diversos 'territorios de la comunicación' que se definen a partir de parámetros tanto geográficos (nacional, provincial, local, regional) como sectoriales (administración pública, sindicatos, etc). Dentro de este campo de conocimiento, particularmente, el territorio de la 'comunicación gubernamental' - local - ha constituido el foco de la atención de nuestro equipo de investigación durante los últimos años, con el objetivo de analizar las oportunidades y restricciones que experimentan los diver-

I Trabajo presentado en el XI Congreso Nacional y IV Congreso Internacional sobre Democracia, organizado por la Facultad de Ciencia Política y Relaciones Internacionales de la Universidad Nacional de Rosario (2014). Agradecemos los comentarios de los organizadores y participantes del Simposio: Impactos y desafíos de la democracia participativa. 
sos actores involucrados (gobernantes, medios y ciudadanos) a partir de factores estructurales, así como, consecuentemente, contextuales y de organización. ${ }^{2}$

Particularmente, considerando que en los procesos de ampliación o profundización democrática que apelan a la "proximidad" como condición de posibilidad de la transformación - ampliamente abordados tanto desde la ciencia política como desde la administración pública- se observa una falta de atención a la comunicación del "sector público" y sus contribuciones a la ampliación del espacio público. Las premisas que sustentan dichas propuestas, tanto teóricas como de gestión, se centran particularmente en lo que refiere a la relación gobernantegobernado. Esto es, la publicación de información gubernamental es considerada una condición necesaria de la minimización de las asimetrías de información existentes en las deliberaciones públicas que orientan la acción del Estado y, consecuentemente, una condición de posibilidad de la participación informada de los ciudadanos y ciudadanas en los procesos de toma de decisiones democráticos, de construcción de la ciudad. (Cf ANNUNZIATA, 2011; CANEL; SANDERS, 2007; DEMERS; LAVIGNE, 1998, 2007; WOLTON, 1995)

Los abordajes vinculados a la comunicación gubernamental fluctúan, entonces, en un arco de intereses entre la persuasión y el derecho a la información, entre los más destacados. Adquiriendo mayor preeminencia en la última década los debates en torno de este último, particularmente, en lo que se refiere al "acceso a la información pú-

2 Destacamos en el contexto de estos debates los trabajos realizados o en proceso de los miembros de este equipo: "Poder comunicativo y presupuesto público: materialización de las experiencias de participación ciudadana en las definiciones presupuestarias de los municipios cordobeses" , subsidiado por GRF - MinCyT Córdoba, directora: C. Echavarría, co-director: A. Buffa (2006-2007); “Democracia Deliberativa en Córdoba: análisis de los alcances y limitaciones de algunas experiencias participativas, contribuciones para su factibilidad", subsidiado por GRF - MinCyT Córdoba, directora: P. Cáceres, co-directora: C. Echavarría (2009-2011); "Pretensiones democráticas de la comunicación gubernamental: estudio de los mensajes del departamento ejecutivo de la ciudad de Córdoba (2012-2013)”, subsidiado por SeCyT-UNC, directora: C. Echavarría. 
blica"3 y la "transparencia" (en función del derecho a la propiedad y la previsibilidad de la toma de decisiones de los actores económicos), considerados una condición necesaria de la comunicación. (RIORDA, 2006) Así, la problematización de la comunicación gubernamental como sinónimo de información pública ha estado vinculada, en los procesos de Reforma del Estado, a los desarrollos referidos a la accountability horizontal - circulación de información dentro del sistema político para el control entre poderes - y vertical - oportunidades para el control ciudadano-, a la preocupación con la eficacia en el cumplimento de las funciones y tareas del gobierno (gobierno electrónico) y a la promoción de la democratización de la gestión pública (construcción de consensos, legitimación de la acción pública). Y, más recientemente, al ejercicio de los derechos ciudadanos, cuando Sobreira, Borges y Jambeiro (2007, p. 104) afirman:

[...] o não acesso a informação, o acesso reduzido ou o acesso a informações não confiáveis impede e/ou dificulta o exercício da cidadania. Diante deste fato, o acesso a informação, por tanto, se coloca como um direito de valor similar aos demais direitos do cidadão, como saúde, educação ou moradia.

Además, en trabajos anteriores advertíamos que

la discusión sobre el acceso a la información pública es más antigua que su re-edición 'transparente' y se vincula a las tensiones experimentadas por las organizaciones políticas modernas referidas a la 'publicidad' de sus formas de actuación e intervención, de los modos en que construyen la voluntad que guía la acción pública. El eje histórico de estos debates y conflictos ha estado asociado a la tensión público/secreto, esto es, a la difícil relación entre Estado y la información [...]. (BUFFA; ECHAVARRÍA, 2010, p. 101)

3 Se hace necesario distinguir el 'derecho a la información', de la garantía de 'acceso a la información pública’. Esto es, en el primer caso, la posibilidad y capacidad de los ciudadanos de buscar, recibir y difundir cualquier tipo de información, por cualquier medio existente, en un contexto de ejercicio de sus derechos garantizado por el Estado; a la que se suma, en el segundo caso, la posibilidad y protección del derecho de los ciudadanos de conocer la información generada, recibida y/o conservada por las instituciones estatales. 
La publicidad y la comunicación gubernamental como ideal normativo, representan una exigencia de visibilidad, cognoscibilidad y accesibilidad de las acciones gubernamentales y de sus criterios de adecuación a la opinión colectiva, para ser sometidos a la discusión pública formal (poder legislativo) e informal (opinión pública).

Lo anterior es de carácter fundamental para comprender la importancia de analizar las características que asume la comunicación gubernamental, más aún cuando los debates e intervenciones profesionales le adjudican una pretensión de gubermentalidad, es decir, que la práctica de comunicación de los gobiernos parte entre sus objetivos de reducir tensiones entre las demandas de los ciudadanos y las prioridades de la acción pública o gubernamental. (Cf. ELIZALDE FERNANDEZ PEDEMONTE; RIORDA, 2006)

Por todo lo dicho, en nuestro último trabajo nos propusimos analizar las características que asume la comunicación gubernamental de los departamentos ejecutivos municipales, particularmente, considerando la información y enunciados formales de autoridad (discursos, comunicados/conferencias, fundamentos de políticas y proyectos de ordenanza) publicadas en los portales los gobiernos.

Tomamos como referencia para esta empresa el modelo deliberativo de democracia que destaca la necesidad del debate, problematización y participación de los ciudadanos en la toma de decisiones, como condición de legitimidad de las acciones del Estado. Desde esta perspectiva, entonces, adquiere centralidad la participación en la construcción pública de los problemas de gobierno de los potencialmente afectados por las decisiones; así como también, la información pública, el hecho de que todos puedan hablar y la inteligibilidad de los mensajes y/o argumentos que en dichos espacios se esgrimen son condición de posibilidad de la participación. (Cf. GASTIL, 2008)

Con este enfoque deliberativo, más allá de establecer un horizonte normativo, buscamos analizar las condiciones de factibilidad para la universalización del acceso y la participación en el debate de cuestiones de interés y relevancia pública (esferas públicas reales y virtuales), en tanto garantía de la movilización e interacción de los ciudadanos en 
el decir y hacer social. (NOBRE, 2011) Considerando que, las exigencias de la comunicación pública llevada a la esfera de lo gubernamental son considerables, tanto para los políticos como para los empleados públicos. Es en este punto donde se concentran los desarrollos de este trabajo.

En tal sentido, consideramos que la comunicación gubernamental describe "rutinas" (Cf. RIORDA, 2008), a partir de las prácticas que -de modo cotidiano y no necesariamente sistematizado- dan cuenta del estilo de comunicación del gobierno y configuran un modo de entenderlo y/o de significar sus acciones ante la sociedad. Dentro del abanico de prácticas de comunicación, para analizar las formas en que se construyen los nuevos espacios participativos, en el marco de la administración municipal, pusimos nuestra atención en las páginas web de los gobiernos municipales, tomando nota de que el alcance y el volumen de la comunicación digital aumentan constantemente, si bien los estudios de la última década sostienen que los ciudadanos argentinos se informan sobre política principalmente a través de los medios de comunicación tradicionales.

Tabla 1 - ¿Cómo se informa sobre política?

\begin{tabular}{|lllllll|}
\hline & 1996 & 2000 & 2002 & 2008 & 2009 & 2010 \\
Con la familia & $29 \%$ & $30 \%$ & $43 \%$ & $46 \%$ & $44 \%$ & $53 \%$ \\
Los amigos & $18 \%$ & $20 \%$ & $28 \%$ & $32 \%$ & $35 \%$ & $42 \%$ \\
Mis compañeros de trabajo & $10 \%$ & $9 \%$ & $12 \%$ & $18 \%$ & $18 \%$ & $19 \%$ \\
Por la radio & $3 \%$ & $5 \%$ & $6 \%$ & $8 \%$ & $8 \%$ & $7 \%$ \\
Por los diarios & $56 \%$ & $51 \%$ & $59 \%$ & $60 \%$ & $60 \%$ & $66 \%$ \\
Por la televisión & $53 \%$ & $47 \%$ & $46 \%$ & $47 \%$ & $51 \%$ & $56 \%$ \\
Por Internet & $77 \%$ & $76 \%$ & $85 \%$ & $85 \%$ & $91 \%$ & $86 \%$ \\
Otros & - & - & - & $19 \%$ & $20 \%$ & $29 \%$ \\
Ninguno & $2 \%$ & $1 \%$ & $1 \%$ & $1 \%$ & $1 \%$ & $1 \%$ \\
No sabe/No responde & $3 \%$ & $7 \%$ & $1 \%$ & $2 \%$ & $4 \%$ & $2 \%$ \\
(N) & $1 \%$ & - & - & - & - & - \\
\hline
\end{tabular}

Nota: Elaborado en base a la última serie disponible de LATINOBARÓMETRO, para Argentina en la pregunta ¿cómo se informa sobre política? 
Lo dicho hasta el momento nos conduce a explorar, en primer lugar, las características que asumen las relaciones entre la comunicación gubernamental y el soporte de la comunicación digital: Internet. Para lo cual se abren distintos caminos posibles en lo que a calidad se refiere, nosotros en este trabajo nos remitiremos a los atributos del diseño y contenidos de las interfaces, considerando que son estas las que modelan la interacción y condicionan las posibilidades del ciudadano de acceso a la información y, consecuentemente, de participar de manera efectiva en la definición de los fines de la intervención estatal y su monitoreo.

\section{INTERNET, COMUNICACIÓN Y GOBIERNO}

El gobierno ha usado la tecnología de la computación desde que existe; sin embargo, con el boom que produjo internet a finales de los ' 90 se abrieron otras posibilidades de uso, en especial todo lo que concierne a la posibilidad de ofrecer servicios a los ciudadanos, apoyados en su carácter multimedia (incluye texto, imagen, audio y material audiovisual). Si se compara su evolución respecto a la de los medios tradicionales, la diferencia es abismal: para llegar a los 50 millones de usuarios, el teléfono tardó 74 años, la radio 38, las computadoras 16, la televisión 13 y el acceso a internet tan solo 4 años. (VEGA, 2009 Esto también lo podemos ver en la evolución que ha tenido Internet como fuente de información sobre política en los últimos años. (Cf. LATINOBARÓMETRO)

Es en este contexto, que la literatura destaca la importancia de las páginas web dedicadas a los espacios de participación, en la medida en que “[...] permita[n] (de forma sencilla, dinámica y atractiva) explicar el funcionamiento [...] a toda la población, informar de la Convocatoria a las Asambleas, realizar propuestas online, y permitir el seguimiento en la ejecución de las propuestas finalmente priorizadas." (FRANCÉS GARCÍA; CARRILLO CANO, 2008, p. 73) Esto es, informar sobre las características del espacio participativo, mantener actualizada la agenda de su funcionamiento, habilitar el uso de la voz en los procesos decisorios y facilitar el monitoreo ciudadano del proceso y de la ejecución de las decisiones allí tomadas. 
La publicidad y la comunicación gubernamental son tensionadas, entonces, en términos de 'accesibilidad', considerando que "when websites, web technologies, or web tools are badly designed, they can create barriers that exclude people from using the Web"4 $\mathrm{y}$, consecuentemente, de la información necesaria para la toma de decisiones. Esto es, mientras más y mejor información tenga una persona sobre un hecho o asunto (acceso a la información no se refiere solamente a "cantidad" sino - y sustancialmente - a "calidad": veraz, certera, actualizada y pertinente), son mayores sus posibilidades de actuar para conseguir los resultados que desea obtener, en nuestro caso, para participar.

\section{REPENSANDO LA ACCESIBILIDAD}

La accesibilidad es definida como "[...] la posibilidad de que un sitio o servicio web pueda ser visitado y utilizado de manera satisfactoria por el mayor número posible de personas, independientemente de las limitaciones personales que tengan o aquellas limitaciones que sean derivadas de su entorno". (INTECO, 2008, p. 5) En tal sentido, la discusión sobre accesibilidad en el contexto de los espacios destinados a la participación ciudadana busca poner el acento en la factibilidad del acceso universal que supone la web, esto es, relevar las condiciones contingentes en las que dicho principio se desarrolla. Tales como que el público al que se dirige la información referida a espacios participativos es heterogéneo, se compone de ciudadanos y ciudadanas cuyas competencias comunicativas y de manejo del medio para interactuar con diseños complejos varían considerablemente. Otra diferencia radica en que, a pesar de la proliferación tecnológica, no todos los sectores sociales cuentan con acceso a internet, por lo que muchas personas acceden desde lugares públicos tales como los denominados cyber. Además de reconocer que para el 'usuario' web, que posee las competencias y capacidades necesarias, resulta más agradable y hasta un incentivo navegar por un sitio en el que no tiene que 'investigar' dónde

4 Como afirma el World Wide Web Consortium, una organización internacional que desarrolla estándares abiertos para la programación web, procurando asegurar el crecimiento de la web. Ver: World Wide Web Consortium. 
se encuentra la información, sino que puede acceder a ella de manera rápida y efectiva, disminuyendo los costos de la participación al menos en términos de tiempo.

En términos generales los principios del diseño accesible refieren a: la igualdad de uso, la flexibilidad respecto de las preferencias y habilidades individuales respecto de mecanismos y ritmos de interacción, el carácter simple e intuitivo, la facilidad tanto para el aprendizaje en el uso de la interfaz como para la percepción de la información a través de la misma (comprensible), la tolerancia a los errores de los usuarios, el escaso esfuerzo físico requerido para el uso y las dimensiones apropiadas en tamaños y espacios. ${ }^{5}$ En función del presente trabajo, nos enfocamos en cuatro de estos principios que consideramos son de utilidad al momento de realizar el análisis de páginas web destinadas a procesos participativos:

- El carácter simple e intuitivo del diseño (amigable): este debe ser fácil de entender independientemente de la experiencia, los conocimientos, las habilidades o el nivel de concentración del usuario.

- La facilidad para la percepción de la información (comprensible): el diseño debe ser capaz de intercambiar información con el usuario, independientemente de sus condiciones ambientales/ contextuales o sus capacidades sensoriales.

- Escaso esfuerzo físico: el diseño debe poder ser usado eficazmente y con el mínimo esfuerzo posible (por ejemplo, evitando las acciones repetitivas).

- Dimensiones apropiadas: los tamaños y espacios deben ser apropiados para su manipulación y uso por parte del usuario, independientemente de su tamaño, posición, y movilidad.

Con base en estas pautas, hemos construido tres dimensiones de análisis, a saber: identificación, usabilidad y contenido.

5 El Instituto Nacional de Tecnologías de la Comunicación (Inteco) de España, ha trabajado -desde su centro de referencia en accesibilidad y estándares web- en la elaboración de guías prácticas de comprobación de accesibilidad”, los parámetros utilizados en este trabajo parten de los propuestos en la guía denominada "Introducción a la accesibilidad web”. (INTECO, 2008) 
La identificación hace referencia a la posibilidad de reconocimiento del sitio web y de los servicios que ofrece por parte del usuario. Sus indicadores son:

- características de la dirección del sitio web (URL) y de sus páginas internas;

- la existencia de logotipos y eslogans;

- la presencia de datos de contacto e información acerca de la repartición a cargo del la implementación del proceso;

- la explicitación de objetivos de la página interna y su correlación con los servicios que ofrece;

- fuentes y fechas de los contenidos.

Cabe estacar que los expertos en User Experience (UX) diferencian entre el diseño 'accesible' y 'usable'. Mientras las accesibilidad, para estos especialistas, refiere a la posibilidad de que la información pueda ser visualizada desde cualquier dispositivo (o en una gran mayoría de ellos), la usabilidad refiere a la simplicidad, rapidez y posibilidad de acceder a la información, sin obstáculos ni ayuda de terceros, incluso en situaciones de alguna imposibilidad física por parte del usuario, aproximándose a las discusiones sobre accesibilidad tal y como las hemos presentado más arriba. ${ }^{6}$ Siempre considerando que un diseño no es usable en sí mismo en función de sus usuarios potenciales y contextos especiales de uso (en nuestro caso: vecinos de la ciudad que participan, pero también aquellos que no participan, de los espacios existentes para la toma colectiva de decisiones). En este sentido, entonces, observamos las páginas web municipales distinguiendo la navegabilidad y el diseño.

6 Cabe destacar que la Convención de los Derechos Humanos para personas con discapacidades (realizada en diciembre 2006) establece el acceso a la información como un Derecho Humano Básico, igualado a otros como vivienda, educación, salud. Entonces, en la literatura, cuando se habla de accesibilidad web se habla de diseños que permitan la navegación para todo tipo de usuarios, incluyendo a aquellos que no tienen discapacidades pero presentan otro tipo de dificultades como la edad, escasos recursos tecnológicos, ambientes poco propicios y poco conocimiento sobre el uso de tecnologías. (Cf. W3 $\mathrm{C}, 2015$ ) 
La navegabilidad nos refiere a todos los aspectos que ayudan al usuario a navegar por el sitio, es decir, a la estructura de navegación. Los indicadores que hemos tomado para esto son:

- formas de acceder a la información;

- longitud de la página;

- características y estado de los enlaces;

- elementos que orientan al usuario (breadcrums, enlaces para regresar);

- compatibilidad del sitio con diferentes navegadores;

- software necesario para visualizar correctamente la información;

- posibilidad de imprimir;

- recursos de búsqueda;

- secciones de ayuda.

- Mientras que el ‘diseño’ nos remite a las cuestiones estéticas de la interfaz, donde adquieren relevancia:

- uso de colores;

- espacios (separación en párrafos y/o unidades de sentido);

- tipografías;

- 'limpieza'.

Finalmente, el contenido, nos pone en contacto con la información propiamente dicha publicada en los sitios web. En tal sentido, los indicadores que construimos derivan de las características usualmente asociadas a la información pública, tales como veracidad, oportunidad, inteligibilidad y/o sencillez.7 Así como también específicamente para los casos considerados:

- disponibilidad de información básica sobre el proceso participativo (qué es, cómo funciona, quiénes pueden participar, cuáles son los objetivos);

- publicación de sus cronogramas;

7 Cf. BUFFA; ECHAVARRÍA, 2011 
- existencia de espacios de intercambio de opiniones entre el Estado y los ciudadanos (foros y correo electrónico);

- instrumentos de transparencia (proyectos votados; cantidad de asistentes; avances de ejecución de proyectos que permitan el monitoreo ciudadano);

- lenguaje y redacción (amigable, cercano, formas de nombrar a los actores involucrados).

\section{LOS CASOS CONSIDERADOS}

Desde el retorno a la democracia en 1983, el principio representativo que sustenta nuestra democracia ha sido constantemente tensionado. En especial luego de la crisis de 2001 que obligó a repensar las formas de ejercicio del poder que se manejaban hasta entonces, los gobiernos locales necesitaron desarrollar acciones en orden a dar respuesta urgente en sus contextos particulares a las desigualdades económico-sociales que enfrentaba el país, pero también para recuperar legitimidad social de las formas de acción privilegiadas.

Se puso en agenda, entonces, la revisión de los fundamentos de legitimidad que sustentan la intervención del Estado en sus distintos niveles, para que el sistema político administrativo pudiera acceder a la habilitación de las voces con poder para incidir en la formulación de políticas. (Cf. ECHAVARRÍA, 2011a) En este contexto y a simple vista, las ciudades argentinas parecían atravesar un proceso de profundización de la democracia y de promoción de la ciudadanía activa. Discursos y tecnologías, desarrollos institucionales promovidos en los niveles nacional y trasnacional, confluyeron estratégicamente en el espacio local, donde fueron adoptados y después socializados en comprensiones domésticas. Particularmente en lo que respecta al conjunto de lineamientos que orientan la discusión y definición del Presupuesto Participativo, como institución para la gestión participativa de los recursos públicos, cuya implementación se multiplica en este nuevo siglo a lo largo del país. Los diversos análisis atribuyen su difusión a la necesidad de legitimación referida, apelando al potencial de la proximidad y de redistribución del "dispositivo" de gestión. 
El caso del PP de Porto Alegre sirvió como referencia para su implementación en distintas ciudades argentinas en lo que, parafraseando a Dagnino, podríamos denominar una "confluencia perversa" 8 con las experiencias de microplanificación estratégica características de la década de los '90. De hecho, son estas microplanificaciones las que se reconocen en las distintas ciudades como antecedentes del PP en términos de prácticas de gestión participativa.

Los casos de Presupuesto Participativo que, desde entonces, más difusión han obtenido en Argentina son los implementados en las ciudades de Morón, Rosario y Córdoba. El Municipio de Morón está ubicado en el centro del Área Metropolitana de la provincia de Buenos Aires, al oeste de la Ciudad Autónoma de Buenos Aires, tiene una población de 321.109 habitantes (Censo Nacional 2010) y es gobernado una fuerza política de centro izquierda de origen vecinalista Nuevo Morón (Nuevo Encuentro a nivel nacional) que accede a fines de la década del noventa a través del triunfo de la Alianza. La ciudad de Rosario está ubicada en la zona sur de la provincia de Santa Fé, tiene una población de 1.193.605 habitantes (Censo Nacional 2010) y se encuentra gobernada por Frente Progresista Cívico y Social (liderado por el Partido Socialista) desde la década de noventa. La ciudad de Córdoba es la ciudad capital de la provincia de Córdoba, en el centro geográfico de la Argentina y en términos poblacionales es el segundo centro urbano del país (1.330.023 habitantes, según el Censo Nacional 2010); desde finales de la década de noventa ha sido gobernada alternativamente por diversas fuerzas políticas (Unión por Córdoba, Frente Cívico y Social y Unión Cívica Radical). En tal sentido, estos casos dan cuenta de lo que afirmáramos en otros trabajos, la implementación de PP en Argentina no ha estado asociada a una fuerza política en particular.

\footnotetext{
8 Dagnino (2006) utiliza este término para referirse a la confluencia entre el proyecto neo-liberal y su correspondiente configuración del Estado y los proyectos participativos de la profundización de la democracia que se difunden en Latinoamérica. Dicha confluencia sería perversa ya que los sentidos de la participación ciudadana y del proyecto neo-liberal son diferentes y hasta opuestos.
} 
Cuadro 1 - Ciudades, partidos y "pasadores"

\begin{tabular}{|l|l|l|l|l|}
\hline CIUDAD & INSTITUCIÓN & AÑO & $\begin{array}{l}\text { ACTORES } \\
\text { VINCULADOS A LA } \\
\text { IMPLEMENTACIÓN }\end{array}$ & $\begin{array}{l}\text { PARTIDO EN } \\
\text { EL GOBIERNO }\end{array}$ \\
\hline $\begin{array}{l}\text { Rosario } \\
\text { (pcia de Sta. Fe) }\end{array}$ & $\begin{array}{l}\text { Presupuesto } \\
\text { Participativo }\end{array}$ & 2002 & $\begin{array}{l}\text { Universidad } \\
\text { Nacional de Rosario }\end{array}$ & $\begin{array}{l}\text { Frente } \\
\text { Progresista } \\
\text { Cívico y Social } \\
\text { (socialismo) }\end{array}$ \\
\hline $\begin{array}{l}\text { Morón } \\
\text { (pcia de Bs. Aires) }\end{array}$ & $\begin{array}{l}\text { Presupuesto } \\
\text { Participativo }\end{array}$ & 2006 & $\begin{array}{l}\text { NUEVO } \\
\text { ENCUENTRO } \\
\text { (d. 1999 Martín } \\
\text { Sabatella) }\end{array}$ \\
\hline $\begin{array}{l}\text { Córdoba } \\
\text { (pcia de Córdoba) }\end{array}$ & $\begin{array}{l}\text { Presupuesto } \\
\text { Participativo }\end{array}$ & $\begin{array}{l}2008 \\
2005\end{array}$ & $\begin{array}{l}\text { Área Prácticas } \\
\text { Participativas de } \\
\text { Gestión Asociada / } \\
\text { FLACSO }\end{array}$ & $\begin{array}{l}\text { Frente Cívico y } \\
\text { Social }\end{array}$ \\
\hline
\end{tabular}

Fuente: adaptado de ECHAVARRÍA, 2011b.

Tabla 2 - Presupuestos Municipales

\begin{tabular}{l|l|l|l}
\hline CIUDAD & $\begin{array}{l}\text { PRESUPUESTO } \\
\text { TOTAL (2012) }\end{array}$ & PP & \% PP/Pres T \\
\hline Morón & 617.490 .000 & $3.615 .264 *$ & 0,59 \\
\hline Rosario & 2.900 .371 .301 & $42.000 .000 * * *$ & 1,45 \\
\hline Córdoba & 3.215 .018 .809 & $40.154 .079 * * *$ & 1,24 \\
\hline
\end{tabular}

Fuente: adaptado de Buffa-Echavarría, 2012. *monto variable decidido por el Poder Ejecutivo. $* *$ montos derivados de porcentuales definidos por ordenanza municipal.

En el caso de los dos primeros, tenidos como exitosos, su suceso se asocia sobre todo en los flujos crecientes de participación que experimentaron en los primeros años de implementación, a diferencia de la ciudad de Córdoba (Córdoba) que no ha tenido la misma penetración en la sociedad a pesar o quizás por las diversas tentativas de implementación que se sucedieron desde 2001. (Cf. ECHAVARRÍA; ROMANUTTI, 2014)

Rosario fue la primera ciudad en implementar PP (2002), 9 en un contexto en el que se habían ensayado otras alternativas posibles de ca-

9 En el Concejo Deliberante de la ciudad de Rosario se registran diversos proyectos de PP anteriores a su implementación definitiva: 2000 del bloque Unidad de la Izquierda y la Resistencia 
rácter gerencial, donde la participación se concretaba esporádicamente y a través de distintos niveles de reconocimiento y de decisión: actores "relevantes" en la construcción de la ciudad (planificación estratégica de ciudad en los años 1996 y 2002); los vecinos para integrar diagnósticos en los barrios y Distritos (micro-planificación participativa a escala barrial y jornadas participativas de Distrito, de carácter consultivo en 1989 y 2001). Si bien no es posible identificar una única razón que explique la decisión gobierno de optar por el PP, Ford (2007) advierte que su puesta en marcha se dio en el marco de una concepción gradualista y consultiva propia del denominado "modelo catalán" ${ }^{\circ \circ}$ de la participación: “[...] siempre se habló del ciudadano al estilo del que hablan los documentos técnicos de la descentralización en la línea de los catalanes [en los que] la participación se ve como el sucedáneo legitimado frente a la pura eficiencia técnica". (FORD, 2007, p. 55)

En Córdoba, el antecedente inmediato del PP es también la micro-planificación estratégica, que se implementó durante de la década de '9o en algunos barrios de la ciudad, al mismo tiempo que la ciudad era pensada para el mediano y largo plazo en lo que se conoció como Plan Estratégico para la Ciudad de Córdoba (PEC). A pesar de diversos intentos de implementación que se registran pos crisis del 2001, será recién en 2004, cuando una experiencia participativa en el gobierno municipal reciba el nombre de PP, para ser reconocido normativamente en 2008 en estrecho vínculo con otra institución incorporada a la estructura municipal: las juntas de participación vecinal.

En el caso de Morón, la implementación del PP tiene lugar a partir de 2006 , con un diseño apoyado en el de Rosario. En un municipio que era considerado como "la capital de la corrupción", la institución se presenta como respuesta a las demandas por de transparencia.

(UNIR) y vuelto a presentar por el PPS (Partido del Progreso Social) en el mismo año; 2001, el Frente Grande, convocó a una Audiencia Pública no vinculante para discutir el presupuesto municipal 2001, en la que el PP se menciona de manera reiterada. (Cf. FORD, 2007)

10 Tanto la experiencia de Rosario como la de Córdoba reconocen claramente la impronta del modelo de planificación que se desarrolló en Barcelona en ocasión de los preparativos de la ciudad para sediar los juegos olímpicos a inicios de la década del noventa, que incluida la identificación/diferenciación de diferentes niveles de planificación - micro, meso y macro. 
En el siguiente cuadro identificamos los momentos de la participación que describe el proceso del PP en los tres casos considerados en este trabajo.

\author{
Cuadro 2 - El proceso participativo en las experiencias argentinas de \\ Presupuesto Participativo
}

\begin{tabular}{|c|c|c|}
\hline ROSARIO (2002) & CÓRDOBA (2004) & MORÓN (2006) \\
\hline Asambleas Barriales & $\begin{array}{l}\text { Cabildos/Asambleas a } \\
\text { escala barrial o zonal }\end{array}$ & $\begin{array}{l}\text { Reuniones barriales o } \\
\text { Asambleas por zonas }\end{array}$ \\
\hline \multicolumn{3}{|c|}{$\begin{array}{l}\text { Asamblea en la que con la participación de los vecinos de la zona de referencia se } \\
\text { identifican ideas, propuestas y/o problemas (diagnóstico de la situación barrial, en el caso } \\
\text { de Córdoba en el período } 2004-2011 \text { esto también incluía una "priorización de problemas") } \\
\text { y se eligen representantes vecinales para participar de la elaboración de proyectos referidos } \\
\text { a los resultados de la misma. }\end{array}$} \\
\hline $\begin{array}{l}\text { Consejos Participativos } \\
\text { de Distrito, redactan los } \\
\text { proyectos y envío a las } \\
\text { distintas secretarias para su } \\
\text { evaluación }\end{array}$ & $\begin{array}{l}\text { Talleres de presupuesto } \\
\text { participativo (x zona } \\
\text { barrial se redactan los } \\
\text { proyectos asociados a los } \\
\text { problemas identificados) }\end{array}$ & $\begin{array}{l}\text { Consejos Vecinales: elabora } \\
\text { un informe territorial, } \\
\text { que luego será analizado } \\
\text { por las distintas áreas del } \\
\text { gobierno }\end{array}$ \\
\hline \multicolumn{3}{|c|}{$\begin{array}{l}\text { En los tres casos los técnicos municipales participan de las reuniones junto a los vecinos, } \\
\text { se prevé alguna forma de información y/o capacitación para los representantes vecinales }\end{array}$} \\
\hline Estudios de factibilidad & & $\begin{array}{l}\text { Las áreas temáticas } \\
\text { del gobierno, que han } \\
\text { recibido los informes de } \\
\text { cada territorio, elaboran } \\
\text { proyectos }\end{array}$ \\
\hline $\begin{array}{l}\text { Reuniones de las áreas de } \\
\text { gobierno con los CPD para } \\
\text { informar estas evaluaciones, } \\
\text { como así también buscar } \\
\text { alternativas a los que tienen } \\
\text { factibilidad negativa }\end{array}$ & & $\begin{array}{l}\text { Ronda de consultas: los } \\
\text { funcionarios presentan los } \\
\text { pre-proyectos a los vecinos } \\
\text { para discutir alternativas a } \\
\text { lo planificado }\end{array}$ \\
\hline $\begin{array}{l}\text { Confección de lista de } \\
\text { proyectos a votar en la } \\
\text { Segunda Ronda y difusión }\end{array}$ & & $\begin{array}{l}\text { Las áreas del gobierno } \\
\text { finalizan la elaboración de } \\
\text { proyectos }\end{array}$ \\
\hline $\begin{array}{l}2^{\circ} \text { Ronda de Elección de } \\
\text { Proyectos }\end{array}$ & $\begin{array}{l}\text { Votación de proyectos } \\
\text { (desde 2013) }\end{array}$ & Ferias de Proyectos \\
\hline $\begin{array}{l}\text { Jornada de cierre - } \\
\text { Evaluación del Proceso } \\
\text { de PP del año en curso / } \\
\text { Encuentros Interdistritales }\end{array}$ & & $\begin{array}{l}\text { Comisión de Seguimiento } \\
\text { (personas designadas por } \\
\text { cada Consejo Vecinal) }\end{array}$ \\
\hline
\end{tabular}

Fonte: Adaptado de Echavarría (2013). 
A continuación presentamos el análisis de los sitios web de los tres municipios considerados, teniendo en cuenta dos unidades de observación: el home o página de inicio de cada uno de los gobiernos municipales, y las respectivas páginas internas referidas al PP. Para este trabajo se realizó un seguimiento a intervalos regulares durante el período 2012-2013.

\section{Identificación}

Las URL de las 3 páginas web de los municipios son sencillas y fáciles de recordar. Se construyen con el nombre del mismo (Rosario, Moron y Córdoba) y la extensión .gov o .gob. Mientras que en lo que respecta a las páginas internas destinadas a los espacios de participación, solamente en el caso de Morón la URL comparte esas características, dado que suma a la dirección principal las palabras "presupuesto participativo" (indicando la separación de los términos por la barra oblicua que se utiliza para construir URLS). Mientras que en el caso de Rosario ya presenta cierto grado de dificultad al incorporar dos tramos intermedios (sitio, información-municipal) antes de 'pp' y la página interna de Córdoba resulta inaccesible para recordar de memoria, ya que demanda reproducir la secuencia del organigrama municipal hasta llegar a la dependencia responsable del proceso participativo:

- http://www.moron.gov.ar/presupuestoparticipativo

- http://www.rosario.gov.ar/sitio/informacion_municipal/pp.jsp

- http://www2.cordoba.gov.ar/portal/index.php/secretaria-degobierno/subsec-de-participacion-ciudadana/direccion-de-presupuesto-participativo/

En lo que se respecta a los objetivos del sitio, Rosario los presenta en la sección "Bienvenida”, mientras que las páginas de Córdoba y de Morón no presentaban objetivos generales del sitio y en sus páginas internas tampoco presentan objetivos de las mismas, lo cual presupone un usuario conocedor de los contenidos que allí se ponen a disposición y de su importancia y pertinencia para el proceso participativo. 
A su vez, Rosario es el único municipio que cuenta con un logotipo (inclusive traducido a la lengua Quom) que permite identificar clara y rápidamente, más allá de los colores, el sitio gubernamental y, particularmente, la información referida al PP. Finalmente, ninguna de las tres ciudades posee un eslogan, que en la página interna refuerce los ejes que orientan la implementación del espacio participativo en el contexto de la gestión o coyunturalmente en el año de intervención.

Con respecto a los datos de contacto, todos los sitios ponen a disposición del ciudadano usuario de la web algún tipo de contacto, desde las más tradicionales, como el número de teléfono de la repartición responsable y la dirección física de la misma (Córdoba), pasando por el correo electrónico que permita un intercambio en el mismo soporte en que el vecino se aproxima o busca información (Morón y Rosario), hasta la previsión de una línea telefónica gratuita (Rosario), que busca eliminar las diferencias de recursos existentes entre los ciudadanos para la participación.

Cuadro 3 - Identificación

\begin{tabular}{|l|c|c|c|}
\hline CIUDAD & \multirow{2}{*}{ CÓRDOBA } & ROSARIO & MORÓN \\
\cline { 1 - 3 } INDICADORES & $x$ & $x$ & $x$ \\
URL HOME clara y fácil de recordar & & $x$ & $x$ \\
URL de página interna, clara y fácil de recordar & & $x$ & \\
Existencia de objetivos del sitio & & $x$ & $x$ \\
Existencia de logotipo & & $x$ & $x$ \\
Existencia de slogan & $x$ & $x$ & $x$ \\
Datos de contacto con la institución & $x$ & $x$ & \\
-Teléfono & & $x$ \\
-Dirección Postal & & $x$ \\
-Correo Electrónico & & $x$ \\
-Otros & & $x$ & \\
\hline
\end{tabular}

Fonte: Elaboración propia.

Por último, respecto a fuentes y fechas de publicación, que permiten al ciudadano usuario valorar la actualidad, pertinencia y relevancia de la información que accede en el sitio, son datos que están presentes 
en los casos de Rosario y Morón, inclusive en este último el usuario web puede ver la cantidad de veces que cada materia ha sido visitada. Mientras que en el caso del sitio cordobés solamente en algunos casos aparecen las fechas de actualización y no se citan las fuentes de las noticias incorporadas.

\section{Usabilidad}

\section{Navegabilidad}

En estrecho vínculo con la identificación de la información que el ciudadano está buscando, cuando comenzamos a analizar la navegabilidad, el denominado "posicionamiento" de los elementos es clave, ya que el recorrido que hace el usuario con la vista describe un recorrido típico: izquierda-derecha-abajo. Por ese motivo, los expertos en usabilidad recomiendan ubicar el logo (identificación) a la izquierda y arriba, para que el usuario sepa dónde está. Después del logo, la estructura de navegación, para que sepa rápidamente a dónde ir, y a continuación el contenido destacado y normal.

En el caso de Rosario, la página de inicio posee un menú vertical ubicado a la izquierda, con diferentes vínculos. Al PP se puede acceder desde "Gestión", desde "Administración Financiera" (que se encuentra dentro de "Información Municipal”), y desde un menú desplegable ubicado arriba a la derecha (que se corresponde a la opción de "navegación" descrita más arriba), donde el PP se encuentra en zer lugar entre 48 disponibles. De esta manera la información sobre el espacio de participación tiene un total de 3 accesos posibles. Si bien, en los dos primeros, se asume que el usuario sabe que el PP se relaciona a las actividades de la Gestión o a la Administración Financiera, estos “nombres" podrían asumirse como fácilmente relacionables con el PP. No obstante lo cual, sería recomendable avanzar en un estudio de percepción del usuario al respecto.

Al igual que en la anterior, en la página de Inicio de la web de Morón hay un menú vertical ubicado a la izquierda con diferentes vínculos. Al PP, en este caso, se puede acceder desde los enlaces: "Organizaciones comunitarias” y “Desarrollo Estratégico”. Además, ofrece un 
vínculo propio, destacado con una imagen gráfica en un menú vertical ubicado a la derecha. De esta manera, la página principal tiene un total de 3 accesos, además de la opción "mapa del sitio" (si bien este enlace no estaba funcionando correctamente durante el período relevado).

Finalmente, la mayor complejidad en términos de posicionamiento lo encontramos en la página de inicio del municipio de Córdoba. Como en las anteriores, en el inicio hay un menú vertical ubicado a la izquierda, que contiene diferentes links que responden a la organización funcional del municipio. De esta manera, a la información sobre PP se puede acceder desde "Secretaría de Gobierno", a través de "Subsecretaría de Participación Ciudadana y Desarrollo Social”. Este recorrido es la única posibilidad de acceso. Decimos que es la más compleja o 'difícil' para el usuario, en principio, porque asume que el usuario sabe que el PP se encuentra dentro de la Secretaría de Gobierno, instancia de la que depende la "Subsecretaría de Participación Ciudadana y Desarrollo Social” encargada de la implementación del proceso participativo. Pero además, porque en este menú, finalmente no se despliega la opción de vínculo a la información buscada, sino que procede a desplegar otro menú vertical a la derecha en cuyo interior se encuentra la opción “Dirección de Presupuesto Participativo". Es decir, que el usuario debe advertir que el camino que venía realizando cambió sin previo aviso y sin especificar hacia dónde. Además, en ese nuevo menú los nombres de los vínculos aparecen cortados, por lo tanto, es necesario posicionar el mouse sobre cada uno de los links para saber cuál es el del PP.

En las discusiones sobre navegabilidad entre los diseñadores y programadores web, el "mito de los 3 clicks" ha sido muy difundido, asumiendo que si el usuario se ve obligado a hacer más de 3 clicks para llegar a aquello que busca, termina saliendo de la página. Sin embargo, distintos estudios ${ }^{\text {II }}$ demuestran que esto no es así, ya que al usuario no le molestaría la cantidad de clicks mientras pueda llegar a eso que busca sin problemas. Como afirma el experto en UX/UI Carlos Bruscoli,

11 Ver User Interface Engineering, 1997-2015. 
Lo más importante en la web/formato digital, es que el contenido llegue correctamente a los usuarios [...]. Una práctica importante es identificar cuáles son los contenidos principales para poder darles un lugar de fácil y rápido acceso, evitando así que el usuario tenga que hacer +2 clicks para llegar al punto más importante de la aplicación/website. (C. BRUSCOLI, entrevista, 26 de marzo de 2014)

Así de acuerdo a lo expuesto anteriormente, en la página de Córdoba, para acceder al PP hay que hacer 4 clicks, y para llegar hasta la ordenanza que contiene la información básica, 6. Mientras que en la página de Rosario, con dos clicks es suficiente para acceder a la información sobre el PP y en la de Morón, por su parte, con un click es suficiente para acceder a la información sobre el PP.

La página interna del PP de Córdoba se encuentra condensada en una sola página, por lo tanto obliga a scrollear (desplazar línea a línea) para acceder a los contenidos que ella se publican. Además, dicha la página posee un header o encabezado fijo para todas las páginas internas del sitio, con las novedades de la acción de gobierno (noticias), que ocupa casi la mitad superior de la pantalla; por lo que siempre es necesario scrollear para visualizar la información a la que se intenta acceder. Con respecto al scrolling, Loranger (2014) afirma que puede ser un reemplazo elegante para la paginación, pero que “[...] it’s not the answer for most websites. Infinite scrolling is probably not for you if site visitors want to achieve goal-oriented activities, such as when they need to backtrack or find specific information quickly." Además, la autora explica que el scrolling "paraliza" al usuario ya que no tiene necesidad de hacer click para acceder a más información. También es un tipo de diseño que genera ansiedad, como un "abismo de información”, solamente jerarquizada según la última actualización.

Mientras que Rosario y Morón, por su parte, tienen la información distribuida por paginación, por lo tanto para acceder a la información hay que hacer click en los enlaces que indican las distintas secciones. De esta manera es la estructura de la navegación la que da cuenta de las jerarquías en los contenidos en la página. 
Los enlaces también son importantes en cuanto a la navegabilidad, ya que son los que nos permiten ir desde un punto de la página hacia otro, es decir, de una información hacia otra. Por lo tanto, es importante poder reconocerlos fácilmente, y además estos deben funcionar. En la página de Córdoba, algunos enlaces son difíciles de reconocer, dado que como afirmáramos anteriormente los nombres aparecen incompletos (enlaces que ocupan más de una línea) y se hace necesario posicionar el mouse sobre dichos enlaces para poder leerlos completos, también hay enlaces que no llevan a ningún sitio y otros que llevan al diseño anterior de la página, como el de Presupuesto, donde aparece el mensaje "presione el siguiente link y será re-direccionado al nuevo portal de la Municipalidad de Córdoba”. En los casos de Rosario y Morón los contenidos asociados al municipio y al PP son fácilmente reconocibles ya que el texto es de otro color. No existen enlaces "rotos", todos funcionan y es posible acceder a la información desde el año 2003, cuando se implementó por primera vez el PP en el municipio de Rosario, y desde el año 2006, cuando se implementó por primera vez el PP en el municipio de Morón (si bien este dato podría ser atribuible a otras razones que exceden al diseño como la continuidad de la fuerza política en el gobierno de la ciudad).

Los enlaces también aparecen en forma de elementos que orientan al usuario, por ejemplo aquellos que permiten volver a la página anterior. Estos son muy útiles ya que ofrecen una experiencia de uso más agradable al permitir que el usuario evite subir y bajar por toda la página o volver a hacer click en las secciones a las que quiere acceder. En este sentido, se destaca el sitio rosarino que ofrece, cuando se revisa o accede a cualquier información, en la parte superior de la página un enlace para volver al principio o atrás. Los sitios de Córdoba y de Morón no tienen estos elementos de navegación que orienten al usuario, pero todos los links de acceso permanecen fijos a la derecha, dejando visible la estructura de la misma.

En un nivel más técnico, la compatibilidad del sitio con diferentes navegadores y el software necesario para visualizar correctamente la información son aspectos fundamentales si queremos hablar de acce- 
sibilidad. Por eso, durante los diversos accesos hemos probado acceder a los sitios desde los navegadores Google Chrome, Safari, Mozilla Firefox e Internet Explorer, y en todos ellos las páginas funcionan correctamente, por lo tanto son compatibles. No obstante lo cual, independientemente del navegador, todas las páginas requieren de software adicional para visualizar correctamente la información, tales como software que permite ver imágenes en movimiento. Es en la página de Rosario, al pie, que se advierte en algunas secciones la necesidad del uso de Flash (para visualizar imágenes en movimiento) y de Adobe Reader (para leer archivos de extensión .pdf); así como también que el mismo sitio facilita su descarga en el caso de que sea necesario.

Otra recomendación al momento de realizar una página web es hacerla pensando en que pueda ser impresa, ya que hay muchos usuarios que - por distintos motivos - prefieren o necesitan imprimirla. En este caso, solamente la página de Córdoba no se puede imprimir sin problemas. En primer lugar, no hay opciones de impresión en la propia página, y cuando se marca esa opción desde el navegador que se está usando el formato de la página se "desarma" y la información no queda organizada para imprimirla correctamente. En los casos de Rosario y Morón, si bien tampoco presentan la opción de imprimir en la misma página, desde el navegador se accede y la vista previa la información aparece organizada exactamente igual que en la página web, es decir que el diseño está pensado para que sea imprimible.

Los recursos de búsqueda también son necesarios y útiles para encontrar más rápido y en forma más sencilla la información que buscamos. Las páginas de Córdoba y Rosario ofrecen navegadores en sus páginas de inicio, no así Morón. En el caso de Córdoba, no permite una búsqueda avanzada: el buscador solamente permite ingresar palabras clave, con una caja de texto es infinita. El navegador de Rosario permite la búsqueda por palabras y números de más de 3 caracteres y también permite realizar búsquedas específicas, mediante un formulario de búsqueda avanzado. En este caso, la caja de texto posee un límite de 40 caracteres. En la página de Morón, como se dijo, no hay opción de bús- 
queda excepto en algunas secciones (que no están relacionadas al PP). En dichos casos, la búsqueda es avanzada y la caja de texto es infinita.

Los resultados de las búsquedas se muestran de manera clara en todos los casos, pero solamente Rosario asiste al usuario en el caso de que la búsqueda sea infructuosa. La mencionada página arroja un enlace para realizar una "Nueva búsqueda" sin tener que volver al buscador y además ofrece ayuda sobre cómo buscar.

Por último, las secciones de "Ayuda" ofrecen al usuario respuestas a las posibles preguntas que le pueden surgir durante la navegación, como por ejemplo dónde encontrar alguna información o cómo realizar alguna acción. Ninguna de las páginas posee una sección de ayuda, excepto la de Rosario que presenta un enlace de ayuda dentro del buscador, que como decíamos explica cómo realizar una búsqueda exitosa.

Cuadro 4 - Usabilidad de sitios web municipales

\begin{tabular}{|c|c|c|c|}
\hline & CÓRDOBA & ROSARIO & MORÓN \\
\hline Cantidad de accesos a página interna & 1 & 3 & 3 \\
\hline Cantidad de clicks para acceder & 4 & 2 & 1 \\
\hline Enlaces fácilmente reconocibles & & $x$ & $x$ \\
\hline Existencia de enlaces rotos & $x$ & & \\
\hline Elementos de orientación & & $x$ & \\
\hline Control de longitud de página & & $x$ & \\
\hline $\begin{array}{l}\text { Compatibilidad del sitio con distintos } \\
\text { navegadores }\end{array}$ & $x$ & $x$ & $x$ \\
\hline $\begin{array}{l}\text { Necesidad de software adicional para la } \\
\text { correcta visualización }\end{array}$ & $x$ & $x$ & $x$ \\
\hline Posibilidad de imprimir correctamente & & $x$ & $x$ \\
\hline ¿Permite la búsqueda avanzada? & & $x$ & \\
\hline Los resultados son comprensibles & $x$ & $x$ & $x$ \\
\hline Caja de texto suficientemente ancha & $x$ & $x$ & $\mathrm{x}$ \\
\hline Asistencia al usuario & & $x$ & \\
\hline Existencia de Ayuda & & $x$ & \\
\hline
\end{tabular}

Fonte: Elaboración propia 


\section{Diseño}

Una de las características más generales en el diseño es la "limpieza" de la interfaz, es decir, la minimización de ruido visual. Revisando esta característica encontramos que, en principio, la jerarquía visual ${ }^{12}$ está bien expresada dentro de las tres páginas, las que como analizamos anteriormente utilizan menús desplegables y, en los textos, diferencian claramente los títulos de los contenidos.

El sitio de Rosario presenta una interfaz limpia. La mayor parte de la página es de color blanco, lo que permite un mayor contraste con el texto y las imágenes además de permitir descansar la vista. La de Morón, por su parte, es una interfaz que presenta algunos elementos que contribuyen al ruido visual, asociados al color rojo usado de manera dominante y a las imágenes en movimiento de la botononera del menú situado a la derecha de la página, si bien posee zonas en blanco que permiten descansar la vista. En el caso de la página web de Córdoba, al acceder a la misma en primera instancia visualizamos una ventana emergente (pop-up) que va cambiando su contenido según la agenda del gobierno. La portada, como dijimos anteriormente, se mantiene fija obligando al usuario a scrollear para acceder a la información. Con predominio del color verde, se registran zonas en blanco pero son mínimas, por lo que la vista no descansa mucho. En síntesis, las páginas de Rosario y Morón usan el color negro para el texto, el cual contrasta con sus respectivos fondos (blanco en el caso de Rosario, gris en el caso de Morón), mientras la página de Córdoba usa el color gris para el texto, el cual disminuye el contraste con el color de fondo (blanco).

Es interesante mencionar que un buen diseño debería tener en cuenta que existen personas que sufren de daltonismo o que son ciegas a percibir algunos colores, por lo tanto se recomienda usar colores como azul, blanco, negro, gris. En este sentido, el verde no es un color recomendable ya que es uno de los colores que las personas con estas dificultades visuales suelen confundir.

\footnotetext{
12 Entendiendo a "jerarquía visual" como una forma de diagramación de texto donde se entiende que cierta información está contenida dentro de otra, es decir que pertenece a una parte mayor.
} 
Finalmente, cabe destacar en este punto que, para conseguir una mejor experiencia de lectura, en especial cuando se trata de artículos largos, las recomendaciones que dan los diseñadores no se remiten solamente al color, sino que tienen que ver con el uso de tipografías con caracteres separados, que los párrafos y las líneas estén lo suficientemente separados, que los títulos y los links estén diferenciados. Además se recomienda utilizar grillas de texto con un ancho de hasta 70 caracteres por línea.

Los títulos de los textos aparecen bien diferenciados en las tres páginas, no así los enlaces (ver análisis sobre navegabilidad). Respecto a los caracteres por línea, reforzando lo anterior, el sitio de Córdoba tiene un promedio de 80; el de Morón de 63 y el de Rosario de 50. Las páginas de Rosario y Morón respetan la separación entre párrafos y términos en todos sus textos; sin embargo, en la página de Córdoba hay textos que no presentan la debida separación, como por ejemplo en la publicación de los proyectos y obras para el PP 2013: todo el contenido aparece condensado y sin espacios en blanco, por lo tanto para distinguir los bloques de información hay que observar atentamente. Así, para no confundir los datos es necesario que el ciudadano realice un esfuerzo de lectura, además, demandar la utilización otros comandos para aumentar su tamaño (zoom de pantalla), lo cual se puede hacer si el usuario cuenta con los conocimientos necesarios para llevar a cabo dicha acción.

Cuadro 5 - Diseño de los sitios web municipales

\begin{tabular}{|l|c|c|c|}
\hline & CÓRDOBA & ROSARIO & MORÓN \\
\hline Interfaz limpia & & $\mathrm{x}$ & $\mathrm{x}$ \\
Jerarquía visual bien usada & $\mathrm{x}$ & $\mathrm{x}$ & $\mathrm{x}$ \\
Uso de colores & & $\mathrm{x}$ & $\mathrm{x}$ \\
Existencia de "zonas en blanco" & $\mathrm{x}$ & $\mathrm{x}$ & $\mathrm{x}$ \\
Contraste entre texto y fondo & & $\mathrm{x}$ & $\mathrm{x}$ \\
Tamaño de texto legible & & $\mathrm{x}$ & $\mathrm{x}$ \\
Separación entre párrafos/términos & & $\mathrm{x}$ & $\mathrm{x}$ \\
Ancho de texto hasta 70 caracteres & & $\mathrm{x}$ & $\mathrm{x}$ \\
\hline
\end{tabular}

Fonte: Elaboración propia. 


\section{Contenido}

Retomando la idea central del trabajo, que afirma que la información es condición de posibilidad para la participación ciudadana, la dimensión de análisis referida al contenido es en este caso en la que podremos ver la pertinencia y adecuación de la información más allá de los diseños y los obstáculos para encontrarla. Por que como afirmábamos anteriormente, si la información está completa y bien elaborada de manera que resulte significativa para el ciudadano y responda a las búsquedas del usuario, los problemas de usabilidad pasan a un segundo plano. Es decir, de nada serviría una página que cumpla con todos los estándares web y no provea de la información necesaria.

En este sentido, al comparar las páginas web de los 3 municipios encontramos que las páginas de Rosario y Morón tienen enlaces específicos dentro del PP donde explican qué es, cómo funciona, cuáles son sus objetivos, quiénes pueden participar y cuándo. La Municipalidad de Rosario, inclusive, incluye un manual donde se explica cómo hacer un Presupuesto Participativo. Mientras que en el caso de Córdoba, esa información se encuentra contenida solamente en la ordenanza que regula el proceso participativo, escrita en lenguaje jurídico. En lo que respecta a los objetivos del PP, Morón y Rosario los explicitan de manera clara y ordenada, con enlaces propios los llamados "Objetivos", en el caso de Morón, y los “Fundamentos”, en el caso de Rosario. En la página de Córdoba no se encuentran consignados los objetivos.

En cuanto al lenguaje que se utiliza para producir la información, es recomendable que sea cercano y amigable para el usuario, redactado de forma clara y sencilla para agilizar la lectura. En el caso de Córdoba, el lenguaje es neutro y la redacción sencilla, pero la ordenanza donde el ciudadano debe remitirse para obtener detalles del proceso participativo, esto es, donde se encuentra la explicación de qué es y cómo funciona el PP está escrita en lenguaje jurídico (es una ordenanza), por lo que demanda contar con cierto vocabulario técnico para comprenderla en su totalidad. En los casos de Rosario y Morón, el lenguaje y la redacción son sencillos y claros, además Rosario posee toda la información traducida a la lengua Quom. 
Otro dato que es interesante de conocer es quiénes son los actores que participan, para el usuario web que busca información sobre quién puede participar y quienes participan o han participado en su región o barrio, ya que ese registro puede generar datos de contacto para promover otras instancias de participación y articulación. Además, esto daría cuenta también de la cantidad de asistentes y permitiría llevar un control sobre el proceso en general y su evaluación en términos de aumento -o no- de la participación. Las páginas de Rosario y Morón, publican la cantidad de asambleas realizadas y a la cantidad de participantes. En Rosario está disponible la cantidad de votos que recibió cada proyecto y un detalle de la cantidad de asistentes en versión .pdf para descargar desde la biblioteca. El municipio de Morón también lleva el registro de participantes por año, expresado en números enteros y expresados en términos porcentuales mostrando aumento o merma respecto a los años anteriores. En ningún caso se pone a disposición de los 'vecinos' el listado de los delegados resultantes en las diferentes instancias, mucho menos alguna forma de contacto posible con los mismos.

En lo que respecta a la forma de nombrar a los actores involucrados, en todas las publicaciones de las páginas se usa la palabra "vecino" como sinónimo de "ciudadano", lo cual demandaría avanzar, en futuros análisis, sobre los sentidos atribuidos a la noción de vecino en cada uno de los casos y sus implicancias para los procesos democráticos implementados.

Otro tipo de contenido que es importante que aparezca es la información sobre el estado de las obras votadas, lo que permite el monitoreo ciudadano no solo de los que continúan participando de manera directa a lo largo del proceso, sino también de los ciudadanos en general. En Rosario, en la sección "Biblioteca”, están todos los archivos que contienen las ejecuciones de obras (según criterios de la ejecución presupuestaria) y los proyectos votados disponibles para descargar en .pdf, además de informar sobre los proyectos votados y obras concretadas en la sección noticias. En la página moronense la información sobre las obras pautadas, ejecutadas y a ejecutar debe buscarse en la sección noticias. El avance y ejecución en la página de la municipalidad 
de Córdoba es confuso, debido a la coexistencia de dos diseños (el de la gestión actual y el de la anterior) y la falta de fechas en las publicaciones. También es posible conocer la concreción de algunas obras, por las publicaciones realizadas en la sección noticias del home, en las que generalmente se informa las actividades desarrolladas por el intendente.

En este sentido, es importante señalar que una de las características que define a internet como medio de comunicación es su capacidad de actualización. Bajo esta premisa e incorporando el concepto de inmediatez, han surgido herramientas como Twitter, aplicaciones de búsqueda como google instant search, ${ }^{13}$ software de transmisión o streaming, ${ }^{, 4} \mathrm{O}$ aplicaciones para teléfonos móviles como whatsapp, ${ }^{15}$ para mencionar algunas. La actualización y la inmediatez son -además de características propias de internet- las ventajas distintivas del medio. En los casos que estamos analizando, entonces, es esperable que la información esté actualizada para que cumpla con el requisito de oportunidad, de manera de extender el proceso participativo de la priorización de las obras al monitoreo continuo de su ejecución. En ese sentido, se observan distintos ritmos de actualización entre las páginas, tal vez asociados a los propios ritmos que asume la implementación del proceso participativo.

Más específicamente, relacionado con lo último que afirmamos, observamos la publicación de cronogramas de asambleas, dato que consideramos necesario para ampliar la convocatoria (más allá de las formas de comunicación directa, propia de estos espacios) y hacer efectiva la participación. Tanto las páginas de Morón como la de Rosario, anuncian la inminencia del comienzo del proceso, así como las fechas, horarios y direcciones de las distintas reuniones que tendrán lugar a lo

\footnotetext{
13 Consiste en la búsqueda sugerida que efectúa el buscador: al tipear las primeras letras de una palabra, se despliega un menú que contiene sugerencias de búsqueda que coinciden con esas letras. De esta manera la búsqueda se agiliza y se hace más fácil.

14 El streaming permite ver transmisiones radiales y televisivas en vivo y en directo por internet.

15 Es un sistema de mensajería gratuito que se utiliza con los teléfonos celulares. Actualmente pertenece a Facebook, que lo ha incorporado a su red.
} 
largo de la ciudad. En el caso de Córdoba, durante el período observado, fue publicado un cronograma que no contiene ninguna especificación sobre la naturaleza de la reunión a la que hace referencia.

En todos los casos, las oportunidades para el 'dialogo' se restringen a formas individuales definidas por las formas de ofrecidas (teléfono, correo electrónico). Ninguno de los casos avanzó, durante el período considerado, en la creación de foros o salas de chat que habiliten la interacción dialógica no solo ciudadano-funcionario, sino también ciudadano-ciudadano y/o ciudadano-funcionario-ciudadano. Lo que permitiría tanto el intercambio de información y saberes, como la integración y/u organización de aquellos ciudadanos que por primera vez se aproximan a la experiencia.

\section{Cuadro 6 - Contenidos}

\begin{tabular}{|c|c|c|c|}
\hline & CÓRDOBA & ROSARIO & MORÓN \\
\hline $\begin{array}{l}\text { Información básica sobre el } \\
\text { proceso }\end{array}$ & & $\mathrm{x}$ & $x$ \\
\hline El sitio está actualizado & & $x$ & $x$ \\
\hline Lenguaje adecuado & & $x$ & $x$ \\
\hline $\begin{array}{l}\text { Existencia de instancia de } \\
\text { diálogo }\end{array}$ & & & \\
\hline $\begin{array}{l}\text { Publicación de cronogramas } \\
\text { de asambleas }\end{array}$ & & $x$ & $x$ \\
\hline $\begin{array}{l}\text { Registro de la cantidad de } \\
\text { participantes }\end{array}$ & & $x$ & $x$ \\
\hline $\begin{array}{l}\text { Publicación de actas de } \\
\text { reunión }\end{array}$ & & & \\
\hline $\begin{array}{l}\text { Existe información sobre } \\
\text { proyectos }\end{array}$ & $x$ & $x$ & $x$ \\
\hline $\begin{array}{l}\text { Información sobre estado } \\
\text { de obras }\end{array}$ & $x$ & $x$ & $x$ \\
\hline $\begin{array}{l}\text { ¿De qué manera se refieren } \\
\text { a los ciudadanos? }\end{array}$ & $\begin{array}{l}\text { Usa "vecino" } \\
\text { como sinónimo } \\
\text { de "ciudadano". }\end{array}$ & $\begin{array}{l}\text { Usa "vecino" } \\
\text { como sinónimo } \\
\text { de "ciudadano". }\end{array}$ & $\begin{array}{l}\text { Usa "vecino" } \\
\text { como sinónimo } \\
\text { de "ciudadano". }\end{array}$ \\
\hline
\end{tabular}

Nota: Elaboración propia. 


\section{CONSIDERACIONES GENERALES}

La revolución tecnológica se expande aceleradamente y modifica la vida en la ciudad. Las TIC juegan un papel importante en esos cambios, ya que pasan a ser un factor esencial para que las personas se inserten plenamente en las sociedades. Por lo tanto, estas transformaciones trazan nuevas responsabilidades al poder público, que se ve obligado a concebir y realizar acciones que ayuden a los ciudadanos a acceder a la información, proveyendo de infraestructura y de servicios de información y comunicación de calidad. (RIBEIRO, et al, 2007)

En lo que respecta a los procesos de democratización de las decisiones colectivamente vinculantes, la incorporación de las TICs suma nuevas tensiones y complejidades que demandan ser tenidas en cuenta porque, como afirman Ribeiro e otros (2007, p. 52), "Esses recursos tecnológicos podem também provocar o aumento de desigualdades já existentes, sobretudo nos planos sócio econômico, educacional e cultural." En tal sentido sostienen: "O ideal é que seu uso se faça sob inflluência de conceitos que garantem os direitos humanos, como democracia, cidadania e identidade cultural, e que sejam usadas para promover a inclusao social, isto é, a plena participação dos indivíduos nas sociedades em que vivem".

En este trabajo exploramos las formas que asume la comunicación gubernamental en internet, particularmente, observando los sitios web de los municipios. Donde la proximidad física pareciera haber relevado, en la literatura y en la práctica, cualquier esfuerzo en las iniciativas gubernamentales por poner sobre relieve los elementos necesarios para consideración efectiva de todas las posiciones y la participación informada de todos los actores.

Es por eso que, apelando a la visibilidad, cognosibilidad y accesibilidad de las acciones gubernamentales y a la necesidad de su sometimiento al debate público, esto es, a la problematización ciudadana como ideal normativo, buscamos analizar las condiciones de factibilidad del acceso a la información pública, o más ampliamente, del derecho a la información en el ámbito público. Para lo cual pusimos énfasis en la identificación de indicadores vinculados a los atributos de 
los diseños y contenidos de las interfases generadas por los gobiernos locales.

Así, retomando discusiones anteriores, realizadas sobre acceso a la información y transparencia, resignificamos en este trabajo la noción de accesibilidad, de uso corriente en el campo de la discusión tecnológica. Para esto intentamos salir del análisis de las barreras derivadas centralmente de las condiciones físicas del sujeto usuario de la tecnología, para poner sobre relieve los limites contextuales que afectan la capacidad comunicativa de los sujetos en ese campo y, en tal sentido, demandar en la utilización del medio por parte de los gobiernos la generación de entornos amigables, comprensibles, eficaces y apropiados para los procesos participativos.

Con base en estas premisas observamos tres grandes dimensiones en las páginas web municipales: la identificación, la usabilidad y el contenido.

Así, de acuerdo a lo observado en cada caso, el trabajo comparativo sobre los tres sitios web de los municipios considerados -Córdoba, Rosario y Morón- evidencia diferentes niveles de desarrollo del medio, en relación al intercambio comunicativo iniciado por el gobierno para difundir y sostener los espacios participativos. En términos generales, podríamos establecer un arco entre las experiencias, que ofrece cierta complejidad en el caso de Rosario y grandes limitaciones en el caso de Córdoba. Aunque en todas puede afirmarse que el 'contexto' de implementación de las políticas tiñe la finalidad de la comunicación: la transparencia de resultados más que la información de procesos decisorios participativos. Privilegiando, entonces, el acceso a datos presupuestarios en el contenido, lo decidido, antes que a elementos que informen el proceso de toma de decisiones o que faciliten la integración/ articulación entre los ciudadanos en el propio proceso, para decidir lo que se va a hacer.

A partir de los atributos del diseño también creemos que es posible en este punto generar algunas hipótesis sobre el mensaje gubernamental que nos permitan continuar a futuro los análisis, considerando los 'vínculos' a los que se asocia el proceso participativo. Esto es, en 
principio, no se trataría de pensar solamente de los recorridos (cantidad de clicks) que demanda al ciudadano usuario de los sitios web llegar a la información sobre los espacios participativos y sus decisiones, sino también al 'posicionamiento' de la misma en relación a su propia relevancia, en cuanto generadora de voluntad colectiva directamente vinculante para la administración, o supeditada a las formas de la burocracia local. Todo lo cual nos permitiría hablar, en un segundo momento, de la pretensión democrática de la comunicación de los gobiernos que adoptaron iniciativas de apertura democrática de las decisiones, más allá de las características particulares que asumen la 'identificación', la 'navegabilidad' y el 'diseño' en cada uno de los casos. Y en tal sentido, todavía demandar, además de la publicidad de lo hecho, la divulgación de los datos relevantes (tales como vínculos a diagnósticos actualizados sobre las áreas de intervención estatal sometidas a debate) y el establecimiento de las condiciones necesarias, en el entorno de las TICs, para discutir sobre lo que se está haciendo y se va a hacer (información sobre participantes, habilitación de foros, divulgación de las actas de los espacios participativos, entre otros).

\section{REFERENCIA}

ANNUNZIATA, R. "Proximidad”, representación y participación:

El Presupuesto Participativo en Argentina Revista de Ciencias Sociales ICONOS, Quito/Ecuador, n. 40, Mayo, 2011.

ARANCIBIA, C. "Prefacio al concepto de comunicación política: una discusión bibliográfica”. Revista Investigación $\gamma$ Crítica, FLACSO, n. 4 , 2000 .

BUFFA, A.; ECHAVARRÍA, C. "La "transparencia" presupuestaria a partir de la experiencia de los municipios de la provincia de Córdoba”. Revista Studia Politicae, Córdoba, n. 22, dic./mar., 2010-2011.

BUFFA, A.; ECHAVARRÍA, C. Presupuesto Participativo, el debate en el marco institucional argentino. JORNADAS INTERNACIONALES DE FINANZAS PÚBLICAS. Córdoba, 2012. Actas... Universidad Nacional de Córdoba, Córdoba, 2012. 
CANEL, M. J.; SANDERS, K. Para estudiar la comunicación de los gobiernos: un análisis del estado de la cuestión. Rev Comunicación $Y$ Sociedad, v. 23, n. 1. p. 7-48, 2010.

CARVALHEIRO, J. R. "O triângulo bloqueado: media, política e cidadãos na democracia local”. En: CORREIA, J. C. (Org.). Comunicaçao e Política: estudos em comunicaçao. Covilhã: Ed. de la Universidade da Beira Interior, 2005.

DAGNINO, E. Concepciones de la ciudadanía en Brasil: proyectos políticos en disputa. En: CHERESKY, I. (Comp.). Ciudadanía, sociedad civil y participación política. Buenos Aires: Miño y Dávila, 2006. p. 387-410.

DAHLGREN, P. "Theory, Boundaries and Political Communication: The Uses of Disparity". European Journal of Communication, v. 19, n. 1, p. 7-18, 2004 .

DEMERS, F.; LAVIGNE, A. "La comunicación pública: una prioridad contemporánea de investigación”. Rev. Nueva Época, n. 7, ene./jun., p. $65-87,2007$.

ECHAVARRÍA, C. Presupuesto Participativo en Argentina: límites y potencialidades del relato cívico. In: CONGRESO ARGENTINO DE ADMINISTRACIÓN PÚBLICA, 6., Resistência/Argentina, 2011. Actas... Resistência, 2011a.

ECHAVARRÍA, C. De la eficiencia a la legitimidad: Contextos y actores de la participación en Argentina. Jalapa, México: Red de Análisis de Prácticas Participativas, 2011 b.

ECHAVARRÍA, C. ¿Aprendizajes democráticos y ciudadanos? Límites de las experiencias de implementación del Presupuesto Participativo en Argentina. In: ENCONTRO INTERNACIONAL PARTICIPAÇÃO, DEMOCRACIA E POLÍTICAS PÚBLICAS: APROXIMANDO AGENDAS E AGENTES. Araraquara, 2013. Actas... Araraquara, 2013.

ECHAVARRÍA, C.; MAURIZI, V. “La comunicación gubernamental: ¿herramienta para la legitimación de políticas o condición de posibilidad de la participación ciudadana?”. En: VALDÉS; MORALES (Comp.). Industrias culturales, medios y públicos: de la recepción a la apropiación. Córdoba: Universidad Nacional de Córdoba, 2013. COMPANAM. Escuela de Ciencias de la Información, UNC. Disponible en: <http://www.eci.unc.edu.ar/archivos/companam/ponencias/ 
Comunicaci\%C3\%B3n,\%2oPol\%C3\%ADtica\%2oy\%2oDerechos\%2o Humanos/ComunicacionyPolitica_echevarria.pdf>.

ECHAVARRÍA, C.; ROMANNUTTI, V. La factibilidad de la deliberación sobre los recursos públicos: diseños institucionales y prácticas de la ciudadanía en la ciudad de Córdoba. Revista Mas poder local, n. 20, jul. 2014 .

ELIZALDE, L.; FERNANDEZ PEDEMONTE, D.; RIORDA, M. La construcción del consenso. Buenos Aires: Ed. La Crujía, 2006.

FORD, A. Experimentos democráticos: asambleas barriales y presupusto participativo en Rosario, 2002/2005. Tesis doctoral. Programa de Doctorado en ciencias Sociales. FLACSO. Argentina, 2007.

FRANCÉS GARCÍA, F.; CARRILLO CANO, A. Guía metodológica propia de los Presupuestos Participativos. Alicante: Colectivo Preparacción, 2008.

GARNETT, J. “Comunicándose con la ciudadanía” En: IZURIETA, R. et al. Estrategias de comunicación para gobiernos. Buenos Aires: Crujia, 2003.

GASTIL, J. Political communication and deliberation. Estados Unidos: SAGE, 2008.

GERSTLÉ, J. La comunicación política. Santiago de Chile: Lom, 2005.

GRÖNLUND, A.; HORAN, T. A. "Introducing e-gov: History, definitions, and issues”, Communications of the Association for Information Systems,

v. 15, p. 713-729, 2004.

HABERMAS, J. Facticidad y Validez: una conversación sobre cuestiones de teoría política. En: HABERMAS, J. Más allá del Estado Nacional. Madrid: Trotta, 1997. p. 144-166.

INSTITUTO NACIONAL DE TECNOLOGÍAS DE LA COMUNICACIÓN. Guías prácticas de comprobación de accesibilidad: introducción a la accesibilidad web. España: INTECO, 2008. Disponible en: <https://www.incibe.es/file/bpoTrınHdohApbHgFsyFSw>. Acceso en: 25 marzo 2014 .

IZURIETA, R. "La comunicación política en la era del entretenimiento. Un estudio de la comunicación y las relaciones públicas para 
gobiernos". En: IZURIETA, R. et al. Estrategias de Comunicación para Gobiernos. Buenos Aires: Ed. La Crujía, 2002.

LAVIGNE, A. La politización de la información del sector público: propuesta de análisis. En: GAUTHIER, GROSSELIN Y MOUCHON (Comps.). Comunicación y política. Barcelona: Gedisa, 1998. P. 257-275.

SOBREIRA, R.; BORGES, J.; JAMBEIRO, O. "Políticas e gestão da informação pública: caso da Prefeitura de Salvador”. En: JAMBEIRO, O.; SILVA, H. P. da; BORGES, J. Cidades contemporâneas e políticas de informação e comunicações. Salvador: Edufba, 2007.

LANDER, E. Límites actuales del potencial democratizador de la esfera pública no-estatal. 2003. Disponible en: <http://unpanı.un.org/intradoc/ groups/public/documents/CLAD/UNPANooo177.pdf>. Acceso en: 17 marzo 2003 .

LATINOBARÓMETRO. Series de tiempo, ¿Cómo se informa de política? Disponible en: <http://www.latinobarometro.org/latOnline.jsp\#G2>. Acceso en: 17 marzo 2003.

LORANGER H. Infinite Scrolling is Not for Every Website. 2014. Disponible en: <http://www.nngroup.com/articles/infinite-scrolling/>. Acceso en: 17 jul. 2003.

NOBRE, G. Fráguas. "Capital social, comunicação pública e deliberação: a gestão do capital comunicacional público”. In: MAQUES, A.; MATOS, H. Comunicação e política. Capital social, reconhecimento e deliberação pública. Sao Paulo: Ed. Summus, 2011. p. 255-272.

PORTER, J. User Interface Engineering. 2013. Disponible en: <http:// www.uie.com/articles/three_click_rule/>. Acceso en: 17 jul. 2003.

RIBEIRO, A. P. et al. "Dilemas urbanos: municipalidades e políticas de informçao e comunicaçoes". In: JAMBEIRO, O.; SILVA, H. P. da; BORGES, J. Cidades contemporaneas e políticas de informação e comunicações. Salvador: Edufba, 2007.

RIORDA, M. Hacia un modelo de comunicación gubernamental para el consenso. En: ELIZALDE, L., FERNÁNDEZ PEDEMONTE, D.; RIORDA, M. (Ed.). La construcción del consenso. Gestión de la comunicación gubernamental. Buenos Aires: La Crujía, 2006. 
RIORDA, M. "Gobierno bien pero comunico mal: análisis de las Rutinas de la Comunicación Gubernamental”. Revista del CLAD Reforma Y Democracia, Caracas, v. 40, 2008.

USER INTERFACE ENGINEERING. 1997-2015. Disponible en: <http://www.uie.com>. Acceso en: 02 abr. 2014.

VEGA, H. La comunicación de gobierno e internet. En: IZURIETA, R; PERIA, R.; ARTERTON, C. (Comps). Estrategias de comunicación para gobiernos. Buenos Aires: Ediciones La Crujía, 2009.

WOLTON, D. La comunicación política: construcción de un modelo. En: FERRY, J.-M.; OLTON, D. et al. El nuevo espacio público. Barcelona: Gedisa, 1995 .

WORLD WIDE WEB CONSORTIUM. Disponible en: <http://www. w3.org/standards/webdesign/accessibility>. Acceso en: 02 abr. 2014. $\mathrm{W}_{3}$ C. Accessibility. 2015. Disponible en: <http://www.w3.org/standards/ webdesign/accessibility>. Acceso en: 02 abr. 2014. 


\section{EVOLUÇÃO DO USO DA INTERNET NA PARTICIPAÇÃO POLÍTICA DE ORGANIZAÇÕES DA SOCIEDADE CIVIL'}

JUSSARA BORGES, OTHON JAMBEIRO

INTRODUÇÃO

Muitos estudos têm se voltado para as possibilidades de uso político da internet. Alguns pesquisadores acreditam inclusive que essa nova tecnologia poderia reviver o sentido político da democracia direta, tornando-se uma ágora digital. Este trabalho, entretanto, segue uma linha de raciocínio diferente: considera os caminhos que a participação política tem trilhado na democracia, levantando as possibilidades que a internet apresenta para a extensão da participação em democracias representativas, mais que sua substituição pelo modelo direto.

Para a observação empírica do uso da internet para ações políticas, foram selecionadas Organizações da Sociedade Civil (OSC). Essas organizações despontaram como atores sociais relevantes para se observar a participação política, porque tanto a evolução democrática no contexto nacional quanto a evolução de suas práticas têm convergido para impul-

I Esta pesquisa recebe apoio financeiro do Conselho Nacional de Pesquisa (CNPq); e é desenvolvida no âmbito do Grupo de Estudos de Políticas de Informação, Comunicações e conhecimento (Gepicc). 
sioná-las a atuar fortemente neste campo. Elas têm se estabelecido socialmente como agentes capazes de revigorar o poder de comunidades, formar cidadãos, fomentar valores de respeito e colaboração, representar interesses de grupos excluídos etc. (MAIA, 2011)

A apropriação da internet por OSC em Salvador vem sendo estudada pelo Gepicc ${ }^{2}$ desde 2010.3 A partir de 2012, novos dados empíricos coletados permitiram traçar a evolução das aplicações dadas às ferramentas digitais para atuação política dessas organizações, ${ }^{4}$ tornando possível um aprofundamento na compreensão do papel que a internet assumiu nas estratégias e nas ações dessas organizações. Este texto dedica-se exatamente a isso.

Organizado em quatro partes principais, o trabalho se exprime teoricamente por meio de uma discussão sobre a relação entre participação política e internet. Este referencial dá embasamento à análise e interpretação dos resultados encontrados em campo. Além dessas duas partes, há uma terceira, onde são explicados os procedimentos metodológicos empregados, e uma quarta e última, conclusiva, na qual as três outras servem de base para a compreensão de como as Tecnologias de Informação e Comunicação (TIC) inserem-se no contexto da atuação política de organizações da sociedade civil no Brasil.

\section{PARTICIPAÇÃO POLÍTICA E INTERNET: ASPECTOS CONCEITUAIS}

A condição básica para a participação cívica e política dos cidadãos é a percepção da existência de problemas e a consciência de que tais problemas podem ser resolvidos mediante determinados tipos de ação. A comunicação, em todas as suas formas - e agora particularmente com a tecnologia da internet - contribui decisivamente nisso com o fornecimento de informações, opiniões e propostas, a respeito dos pro-

2 Grupo de Estudos de Políticas de Informação, Comunicações e Conhecimento, vinculado ao Instituto de Ciência da Informação/UFBA. Ver Gepicc, 2013.

3 Ver, entre outros: Borges $(2011,2012)$, Borges e Jambeiro (2012b) e Jambeiro e Borges (2010).

4 Ver: Borges, Brandão e Martins (2013), Borges, Lessa e Brandão (2013) e Borges; e colaboradores (2013). 
blemas e de suas soluções. Ela permite, pois, o conhecimento do problema e das variadas formas de solucioná-lo, e notadamente contribui para a formação da vontade de mudar.

Assim compreendido, o processo parece ser de natureza individual. Mas, na verdade, tudo isso ocorre mediado por grupos de referência constituídos na sociedade. Estes grupos assumem diversas formas, entre as quais as chamadas Organizações da Sociedade Civil (OSC). São estas que além de servirem de filtro na percepção dos problemas, se constituem também como instrumentos de adoção das soluções e de negociadores destas com outras organizações e, particularmente com o poder político. Elas são um dos caminhos de que o cidadão dispõe para a participação política, sobretudo no que se refere aos benefícios ou malefícios à sua vida cotidiana.

Reunindo pessoas com interesses mais ou menos convergentes, a OSC se constitui em ente jurídico uno, e age como tal. Isto é, agregando variados indivíduos, articula seus interesses e se apresenta à sociedade e ao mundo político como uma unidade. Este trabalho trata destas entidades, que se constituem de indivíduos, assumem posições, perseguem objetivos e desenvolvem estratégias de ação como uma unidade social e política.

Já a associação da Internet como um instrumento de democratização vem da sua capacidade de potencializar o acesso à informação e à comunicação multidirecional, “[...] porque se a informação somente flui em um só sentido, estamos criando e reproduzindo cidadãos passivos que só se contentam em estar informados e não em participar ativamente dos assuntos públicos." (NUNES, 2007, p. 4)

Dahlberg (2001) observou que a emergência da Internet levou três dos principais modelos de democracia a se voltarem para suas potencialidades. O modelo liberal vê a Rede como um meio poderoso para o cidadão ter acesso à informação atualizada e fazer suas escolhas, qualificando assim a competição de interesses. O modelo comunitarista5 assume a Internet como um meio ideal para o diálogo, através do qual se

5 O "modelo comunitarista" de Dahlberg assemelha-se ao "modelo participacionista". 
descobre identidades e propósitos compartilhados, ou seja, o diálogo é desejável para descobrir o bem comum já existente. Em contraste, o modelo deliberativo define o diálogo como um meio através do qual os participantes podem discutir e entender as diferenças, e decidir racionalmente, sendo a internet um precioso instrumento para a realização deste sonho. Gomes (2005a, p. 218), por exemplo, diz que a introdução dessa nova plataforma tecnológica:

[...] faz ressurgir fortemente as esperanças de modelos alternativos de democracia, que implementam uma terceira via entre a democracia representativa, que retira do povo a decisão política, e a democracia direta, que a quer inteiramente consignada ao cidadão. Estes modelos giram ao redor da idéia de democracia participativa e, nos últimos dez anos, na forma da democracia deliberativa, para a qual a Internet é decididamente uma inspiração.

Outros autores apontam caminhos paralelos que a internet pode construir para a consecução desses modelos de democracia. Johnston (2009) aposta na transparência dos processos políticos já existentes como a base para o aumento da participação do cidadão. Chrissafis e Rohen (2009, p. 91, tradução nossa) acreditam que as tecnologias digitais podem simplificar os processos de tomada de decisão e contribuir para tornar mais claros os textos legislativos: "Estas tecnologias podem ajudar a visualizar os argumentos e os impactos das decisões propostas, monitorar os processos de decisão e permitir aos cidadãos descobrir quais decisões estão sendo tomadas e quando é apropriado agir." ${ }^{6}$ Ronca e Costa (2002) afirmam que a Internet - que representa a principal convergência das tecnologias de informação e comunicação (TIC) e organiza-se em formato de rede - se constituirá no próprio espaço comum do conhecimento, onde a construção de saberes é coletiva, a partir de redes de compartilhamento que se organizam em sistemas circulares ou horizontais de transmissão de informações.

\footnotetext{
6 "These technologies can help visualize arguments and impacts of proposed decisions, monitor decision-making processes and enable citizens to find out what decisions are being taken and when it is appropriate to act."
} 
Isso permitiria que a produção de conhecimento e a difusão de informações fossem cada vez mais distribuídas entre os inúmeros agentes através da web, com um potencial de interação inédito se comparado aos meios de comunicação tradicionais. Nessa linha, Santos (2002) diz que grupos excluídos têm se apropriado das tecnologias para estabelecer laços e se fortalecer: "[...] a intensificação exponencial das relações transfronteiriças e as novas tecnologias de informação e comunicação produziram alterações profundas nas escalas espaciais e temporais da ação social."

Ainda no âmbito das relações entre os indivíduos, Bucy e Gregson (2001, p. 365, tradução nossa) apostam na intensificação da comunicação entre cidadãos e políticos:

Ao invés de ser imposto um papel passivo no processo político, o eleitorado é simbólica ou materialmente empoderado através da arquitetura de comunicação em duas vias para interagir diretamente com os candidatos.?

Mas há também os autores que procuram mostrar que estes caminhos abertos pela internet não estão isolados, nem têm autonomia nem potencial para impor-se e moldar esses novos modelos de gestão democrática. Eles chamam a atenção para, por exemplo, a crescente concentração de propriedade dos grandes meios de comunicação comerciais entre conglomerados que dominam não só a mídia tradicional mas também a própria infraestrutura da internet:

A mídia contemporânea está sendo moldada por várias tendências conflitantes e contraditórias: ao mesmo tempo que o ciberespaço substitui algumas informações tradicionais e gatekeepers culturais, há também uma concentração de poder inédita dos velhos meios de comunicação. A ampliação de um ambiente discursivo coexiste com o estreitamento da variedade nas informações transmitidas pelos canais mais disponíveis. (JENKINS, 2008, p. 276)

7 "Rather than being proscribed a passive role in the political process, the electorate is symbolically or materially empowered through the two-way communication architecture to interact directly with candidates." 
Isso se reflete em todas as áreas da sociedade, inclusive nas campanhas eleitorais. Os candidatos têm usado a Internet e podem mesmo tomá-la como base para suas campanhas, mas sabem que precisam da televisão para ganhar as eleições. Enquanto na "mídia empurrada", as mensagens vão ao público sem que necessariamente este as procure, na "mídia puxada" as informações são buscadas pelo interesse do usuário. (JENKINS, 2008)

Wolton (2006) chama a atenção de que há uma contradição entre um gigante da informação e um anão da ação política, ou seja, a crescente disponibilização de informação, embora condição indispensável para o desenvolvimento democrático, não significa melhor comunicação, nem maior participação política. A comunicação exige, além de um emissor, um meio e uma mensagem, um receptor disposto e apto para ouvir, compreender e interagir. A Internet deu voz a muitos indivíduos e grupos antes "mudos socialmente", mas não pode garantir que de fato sejam ouvidos:

Hoje, saturado por todas as informações que recebe sem poder agir, o cidadão não se pode tornar um 'Apolo da informação'[...] Existe portanto uma disfunção no que respeita ao esquema da sociedade da informação. A informação não só já não cria diretamente comunicação, como também já não cria diretamente capacidade de ação. (WOLTON, 2006, p. 69)

Também numa perspectiva crítica, Kumar (2006, p. 71) avalia que a despeito da potencialidade das TIC para produzir mudanças radicais nos costumes sociais, a nova tecnologia "está sendo aplicada em uma estrutura política e econômica que confirma e reforça padrões existentes, ao invés de gerar outros." Para o autor, aqueles grupos historicamente marginalizados do acesso aos bens e serviços, excluídos da participação política e social e, portanto, alijados de sua cidadania, permanecem clientes passivos, compradores e consumidores.

Os dados empíricos da pesquisa de Gennaro e Dutton (2006), realizada com cidadãos britânicos, corroboram esse ponto de vista: as desigualdades da participação política off-line tendem a ser reproduzidas e aumentadas na participação on-line. Se na participação off-line, os 
indivíduos de grupos socioeconômicos mais baixos apresentam pouco engajamento cívico, menos da metade desses tinham engajamento em participação on-line.

A mesma pesquisa apontou que apenas um quinto dos britânicos usou a Internet para buscar informação política e, embora 92\% deles a usem como canal de comunicação, o contato com os políticos foi o menos frequente entre os usos da Internet. Os autores concluem que o potencial da internet para aumentar o engajamento político online, devido à facilidade de acesso à informação e aumento das oportunidades de comunicação, é subutilizado.

No que tange à comunicação, no entanto, deve-se relativizar a conclusão de Gennaro e Dutton (2006) porque a forma de participação política considerada - contato com políticos - limitou-se à comunicação com um ator social, quando a comunicação política pode ocorrer com outros cidadãos, organizações sociais, instituições públicas, entre outros.

Em parte concordando com Gennaro e Dutton, DiMaggio e outros (2001), baseados em pesquisas anteriores e observando o quesito informação política da perspectiva do acesso, sugerem que a Internet atua mais como um complemento para aqueles que já usavam outras fontes para manterem-se informados do que fomenta esse acesso.

Segue-se que: por um lado, a democracia encontra terreno profícuo para ser fortalecida, “[...] pelo fato de a informação ser amplamente distribuída e os fluxos de informação não poderem mais ser controlados a partir do centro", como atestam Akutso e Pinho (2002, p. 3); e por outro há outros condicionantes, como aponta Maia (2008, p. 285): “Há pouca evidência de que o acesso mais amplo às tecnologias irá, por si e sem mais, expandir o interesse pelas questões políticas simplesmente porque uma parcela maior do público tem chances de participar."

Um exemplo do referido condicionamento é o da elaboração participativa do orçamento de Belo Horizonte feita por via digital. Entre 2006 e 2008, houve um decréscimo do número de participantes de 503 mil para 113 mil. Observa-se que, no período, a Prefeitura disponibilizou canais digitais de votação para a população, com 270 pontos de votação públicos e gratuitos, e monitores treinados para auxiliar 
os cidadãos, além de um número telefônico com ligação gratuita. Isso mostra que há outros condicionantes para a participação política, como, por exemplo, motivação para engajar-se. No caso de Belo Horizonte, a queda da participação se deu na medida que, ao invés de uma dinâmica deliberativa sobre que obras realizar, o orçamento participativo era, na verdade, um plebiscito sobre obras já previamente escolhidas pela Prefeitura.

Assim como os modelos de democracia variam enormemente entre os países e regiões - abrangendo sistemas eleitorais majoritários ou proporcionais, nível de competitividade entre partidos, sistema executivo parlamentar ou presidencial etc. - mais ainda se diferem as formas de participação, a cultura política e, consequentemente, a aplicabilidade da internet para a participação social em cada uma dessas sociedades. Por exemplo, se nos Estados Unidos a Internet foi rapidamente adotada como ferramenta de lobbying e levantamento de fundos para campanhas eleitorais, esse talvez não seja o principal uso que se faz dela em campanhas nas democracias europeias ou latino-americanas.

Sampaio (2010, p. 47), que realizou uma revisão de literatura quanto à relação entre participação política e Internet, acabou por concluir que os seus usos abrem tantas possibilidades que é fácil assumir um discurso triunfalista ou apocalíptico e encontrar evidências empíricas para embasar um e outro discurso. Mas reconhece que "[...] há diversos casos que apontam incremento de valores democráticos, que só foram permitidos pelo uso da Internet." Para Ziba (2007), essa contradição acontece porque a literatura tende a focar o uso da tecnologia em si, negligenciando outros parâmetros. Para ele, a promoção da participação e inclusão através das tecnologias tem de ser um caso de ação sociotécnica, em que as influências sociais e técnicas são igualmente consideradas para promover a participação dos cidadãos. Ele verificou isso ao estudar o caso de Malawi, no qual as experiências mais bem sucedidas foram aquelas em que os atores locais tiveram autonomia para participar das escolhas tecnológicas e escolher como se daria a participação.

Inegavelmente, a Internet facilita práticas de accountability, mobilização de grupos e deliberação pública, o que incide no desenvolvimen- 
to de valores democráticos. Entretanto, a motivação para a participação política está relacionada a outros condicionantes, como a geração de efeitos reais no sistema político - o que implica em vontade política dos representantes -, confiança dos cidadãos na efetividade de sua participação e uma política que mantenha canais e oportunidades de participação abertos e contínuos.

Macintosh e Whyte (2006), a partir da avaliação de programas locais de participação política no Reino Unido, concluíram que a motivação para participar era mais importante que as ferramentas. Por outro lado, "[...] classificar a Internet como neutra é ignorar os avanços democráticos que podem ser conquistados por determinadas utilizações de diferentes ferramentas digitais, usos que não seriam possíveis sem sua presença." (SAMPAIO, 2010, p. 43) Para Gomes (2011), se genericamente tomados, os usuários da Internet não estão grandemente interessados em política, mas podem participar de modo relevante em circunstâncias específicas:

Isso me leva à ideia de que a participação online passa por questões relacionadas ao desejo tanto quanto por questões relacionadas a meios, motivos e oportunidades de participação. Se, quando assim deseja, o cidadão puder encontrar ou criar canais adequados de participação, estará, então, assegurado o princípio segundo o qual numa sociedade democrática saudável, todo concernido deve poder participar, embora nem todos concernidos sejam sempre e efetivamente participantes. O cidadão que usa intensamente tecnologias de conexão digital pode estar em estado de latência no que tange à participação e ao engajamento. (GOMES, 2011, p. 39-40, grifos do autor)

Está claro, portanto, que a literatura é farta na discussão das potencialidades e barreiras da Internet para a participação política. Como um ambiente de comunicação, é natural que ela seja também ocupada pela política como um complemento, mais uma ambientação de temas políticos. (ALMEIDA, 2010) Os estudos teóricos e empíricos consultados para a realização deste trabalho resultaram na constituição de um 
conjunto articulado de potencialidades e limitações da internet, que se mostrou altamente pertinente. Nele, o diferencial é que as unidades pesquisadas não são indivíduos, mas sim organizações que, constituídas para equacionar e resolver problemas sociais em âmbitos específicos, são levadas a desempenhar papéis de natureza política e a utilizar a internet para tal fim.

O conjunto foi organizado articulando as potencialidades e as limitações da nternet nas ações de comunicação, de informação e de procedimentos. (BORGES; JAMBEIRO, 2012) Ali se revela, entre outros aspectos: 1) que apesar de a nternet facilitar o contato e a pressão sobre os representantes eleitos, o sistema político continua fechado; 2) que embora a nternet facilite a produção e circulação de informações sem controle ou filtros do Estado, as OSC não têm produzido e feito circular muita informação de natureza política; 3) e conquanto comodidade, conforto e custo reduzido sejam tidos como incentivadores de participação, não se encontram evidências de que tenha havido incremento de participação política, em função desses fatores.

O conjunto de potencialidades e limitações da internet, que se construiu para a investigação da participação política, foi fundamental para que se pudesse fazer o estudo empírico que é apresentado a seguir. Ele não é, contudo, essencial para que se compreenda os objetivos, a metodologia e os resultados alcançados.

\section{PROCEDIMENTOS METODOLÓGICOS}

A pesquisa foi delineada para verificar as aplicações dadas às ferramentas digitais na atuação política de OSC. A amostra foi composta por organizações sediadas em Salvador, capital do Estado da Bahia, que concentra OSC atuando em frentes múltiplas de defesa de direitos civis e mediações políticas. Dada a quantidade e diversidade dessas organizações, fez-se uma seleção a partir do banco de dados do Cadastro Nacional de Entidades (CNE), do Ministério da Justiça do Brasil. A partir do Relatório Eletrônico de Prestação de Contas que cada organização disponibiliza no CNE, foram utilizados os seguintes critérios de seleção: 
I. organizações que responderam afirmativamente quanto à sua contribuição para ampliação da democracia e fortalecimento da cidadania no Questionário para Avaliação da Inserção Social;

2. organizações que tenham assento como titulares em conselhos de políticas públicas. Com a aplicação desses dois primeiros critérios, buscou-se selecionar aquelas organizações que se dispõem a ter atuação política;

3. organizações que já atuavam em 1995, ano da entrada da internet comercial no Brasil. Com esse requisito procurou-se ter acesso a informações sobre as mudanças demandadas pela inserção das TICs.

Os mesmos critérios foram aplicados na seleção do grupo em 2010 e em 2013. Com a aplicação desses critérios, chegou-se a 44 OSC em 2010 e a 32 OSC em 2013. Neste trabalho, o foco de análise são os dados mais recentes. Contudo, quando pertinente para compreender a evolução do uso da internet, os dados de 2010 são resgatados.

O instrumento de coleta de dados foi um roteiro de entrevista semiestruturada, realizada individualmente com os gestores de cada organização. A análise dos dados foi primariamente qualitativa, tendose adotado para tanto a técnica de análise de conteúdo, por meio da abordagem descritiva, correlacional e interpretativa. Contudo, análises quantitativas foram adotadas, como complementares, visando à representação dos dados por meio de gráficos, quadros e tabelas.

$\mathrm{Na}$ discussão dos resultados, a seguir, algumas falas dos entrevistados são apresentadas, a título ilustrativo dos dados obtidos. Para destacá-las, usou-se o itálico em sua apresentação.

\section{PARTICIPAÇÃO POLÍTICA E INTERNET: ANÁLISE DAS INFORMAÇÕES} EMPÍRICAS

Nesta parte do trabalho, serão apresentados os resultados que constituem sua contribuição original e que são fruto da interpretação dos dados obtidos na pesquisa de campo, levando em conta o referencial teórico construído previamente. 


\section{Caracterização das organizações}

Antes de se tratar da atuação política das organizações, é preciso registrar que nenhuma foi criada com fins políticos. Todas surgem com objetivos específicos de natureza social, que se mantêm ao longo do tempo. Para evidenciar isso, buscou-se uma generalização - embora todas as organizações atuem em mais de uma causa - na qual foram classificadas de acordo com seus objetivos iniciais (Quadro 1).

Quadro 1 - Classificação por área de atuação inicial das organizações

\begin{tabular}{|c|c|c|}
\hline QUANT. & CATEGORIAS & NOME DA ORGANIZAÇÃO \\
\hline 8 & $\begin{array}{l}\text { DEF } \\
\text { Organizações que } \\
\text { direcionam esforços para } \\
\text { defesa de direitos e inclusão } \\
\text { social de pessoas portadoras } \\
\text { de algum tipo de deficiência } \\
\text { física ou mental }\end{array}$ & $\begin{array}{l}\text { Associação de Pais e Amigos Excepcionais } \\
\text { de Salvador (Apae) } \\
\text { Associação Bahiana de Recuperação do } \\
\text { Excepcional (Abre) } \\
\text { Associação Baiana de Deficientes Físicos } \\
\text { (Abadef) } \\
\text { Associação de Pais e Amigos de Crianças } \\
\text { e Adolescentes com Distúrbios de } \\
\text { Comportamento } \\
\text { Associação de Pais e Amigos de Deficientes } \\
\text { Auditivos do Estado da Bahia (Apada) } \\
\text { Instituto de Organização Neurológica da } \\
\text { Bahia (lonba) } \\
\text { Instituto Guanabara } \\
\text { Instituto de Cegos da Bahia }\end{array}$ \\
\hline 8 & $\begin{array}{l}\text { COM } \\
\text { Instituições que atuam } \\
\text { em causas relacionadas à } \\
\text { organização e fortalecimento } \\
\text { de comunidades }\end{array}$ & $\begin{array}{l}\text { Associação Beneficente e Recreativa } 28 \text { de } \\
\text { setembro } \\
\text { Associação das Comunidades Paroquiais de } \\
\text { Mata Escura e Calabetão (Acopamec) } \\
\text { Clube de Mães do Bairro de Pernambués } \\
\text { Coordenadoria Ecumênica de Serviço (Cese) } \\
\text { Fundação Odebrecht } \\
\text { Associação de Moradores do Conjunto } \\
\text { Santa Luzia } \\
\text { Voluntárias Sociais da Bahia } \\
\text { Associação Centro Social Fraternidade } \\
\text { Bahiana }\end{array}$ \\
\hline
\end{tabular}




\begin{tabular}{|c|c|c|}
\hline 6 & $\begin{array}{l}\text { REL } \\
\text { Organizações ligadas a } \\
\text { ordens católicas ou centros } \\
\text { espíritas }\end{array}$ & $\begin{array}{l}\text { Centro Espírita Celeiro de Paz } \\
\text { Centro Espírita Deus, Luz e Verdade } \\
\text { Federação Espírita do Estado da Bahia } \\
\text { (Feeb) } \\
\text { Fundação Lar Harmonia } \\
\text { Instituto Social das Medianeiras da Paz } \\
\text { Fundação Instituto São Geraldo }\end{array}$ \\
\hline 5 & $\begin{array}{l}\text { EDU } \\
\text { Organizações que } \\
\text { começaram suas atividades } \\
\text { voltadas para a educação }\end{array}$ & $\begin{array}{l}\text { Associação e Centro de Educação Maria } \\
\text { Dolores } \\
\text { Instituto Nossa Senhora da Salette } \\
\text { Associação Universitária e Cultural da Bahia } \\
\text { Casa Pia Colégio dos Órfãos de São Joaquim } \\
\text { Colégio do Sagrado Coração de Jesus }\end{array}$ \\
\hline 2 & $\begin{array}{l}\text { ABR } \\
\text { Organizações que têm como } \\
\text { ação prioritária o abrigo de } \\
\text { menores ou idosos }\end{array}$ & $\begin{array}{l}\text { Fraternidade Nossa Senhora da Piedade } \\
\text { (Abrigo Mariana Magalhães) } \\
\text { Casa de Santa Maria }\end{array}$ \\
\hline 2 & $\begin{array}{l}\text { SAU } \\
\text { Organizações que podem ser } \\
\text { enquadradas entre aquelas } \\
\text { que prestam prioritariamente } \\
\text { serviço de promoção e } \\
\text { proteção da saúde }\end{array}$ & $\begin{array}{l}\text { Grupo de Apoio à Criança com Câncer de } \\
\text { Salvador (Gacc) } \\
\text { Núcleo de Apoio ao Combate do Câncer } \\
\text { Infantil (Nacci ) }\end{array}$ \\
\hline 1 & $\begin{array}{l}\text { AMB } \\
\text { Organizações que têm como } \\
\text { foco questões relacionadas } \\
\text { ao meio ambiente }\end{array}$ & Instituto de Permacultura da Bahia \\
\hline
\end{tabular}

Fonte: Pesquisa dos autores, 2013.

Como se pode verificar, elas são bastante heterogêneas, o que as leva a ter metas diversas, a partir de motivações diferentes, escolherem linhas de ação específicas, nem sempre compartilhando os mesmos valores, além de terem visões por vezes conflituosas dos demais atores sociais - principalmente do poder público - e do seu próprio papel político.

Essa classificação generalista estabelece sete grandes categorias de áreas de atuação, entre as quais a participação política não aparece. No entanto, a despeito de manterem seus objetivos fundacionais, essa 
participação posteriormente se impõe como uma atividade essencial para atingir os objetivos "não políticos", conforme transparece na fala:

A gente vai [aos conselhos de políticas públicas] para representar a população. Trazemos as informações desses espaços para a comunidade e levamos os problemas da comunidade para lá também. Assim, esses fóruns contribuem de forma substancial para o desenvolvimento de nossas atividades (REL)

Vale ressaltar, no entanto que, embora em menor número, há organizações que reconhecem que a política está na raiz de sua atuação:

A todo instante fazemos política. Não existem ações nesse nivel que não tenham o cunho político. A política é inerente a essas ações. Se a gente interage com a sociedade, interage com o poder público, interage com os associados, a gente está fazendo política a todo instante. (DEF)

\section{A aplicação da internet na atuação política}

A partir de levantamento realizado por pesquisa anterior (BORGES, 2013), foram propostas 21 formas de participação política às organizações. Todas as formas são praticadas por, pelo menos, uma das organizações, embora filiação e promoção de partido político tenham sido assinaladas por apenas uma. Por isso, essas formas de participação foram excluídas desta parte do estudo, em função de sua baixa relevância frente às demais.

Duas organizações disseram não utilizar a internet em nenhuma das formas de participação política. Com isso, a pesquisa nesta etapa apresenta dados de 30 organizações que, em graus e formas diferentes, relacionaram a internet como ferramenta para levar a cabo a atuação política a que se propõem. O Gráfico 1 ilustra o peso relativo da internet para cada uma das formas de participação. 
Gráfico 1 - O peso da internet na participação política em 2013

- OSC que atuam na forma de participação

- OSC que usam a internet na forma de participaçăo

- Percentual da correlaçăo entre a atuaçăo política e o uso da internet

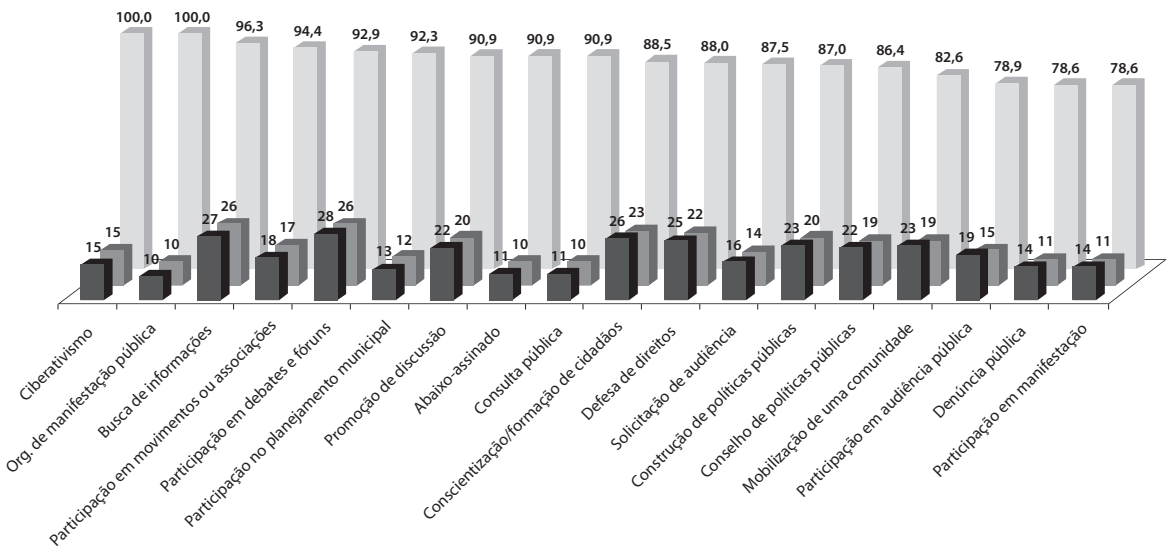

Fonte: Pesquisa dos autores, 2013.

O resultado mais relevante é a constatação do expressivo uso da internet em todas as formas de participação política. Essa é uma informação que difere fortemente da realidade levantada em 2010 (Gráfico 2).

No levantamento realizado em 2010, a internet apresentava-se mais presente no ciberativismo, assim como na busca por informações e na comunicação engendrada para a construção de políticas públicas. Nas demais formas de atuação política, a correlação caía para menos de $60 \%$. Atualmente, além dos recursos digitais serem utilizados em todas as ações, a menor correlação é de 78,6\%, o que demonstra a imprescindibilidade e crescente convergência entre os recursos digitais de informação e comunicação e a participação política praticada pelas organizações. 
Gráfico 2 - O peso da internet na participação política em 2010

- OSC que atuam na forma de participaçăo

-1. OSC que usam a internet na forma de participaçăo

Percentual da correlaçăo entre a atuação política e o uso da internet

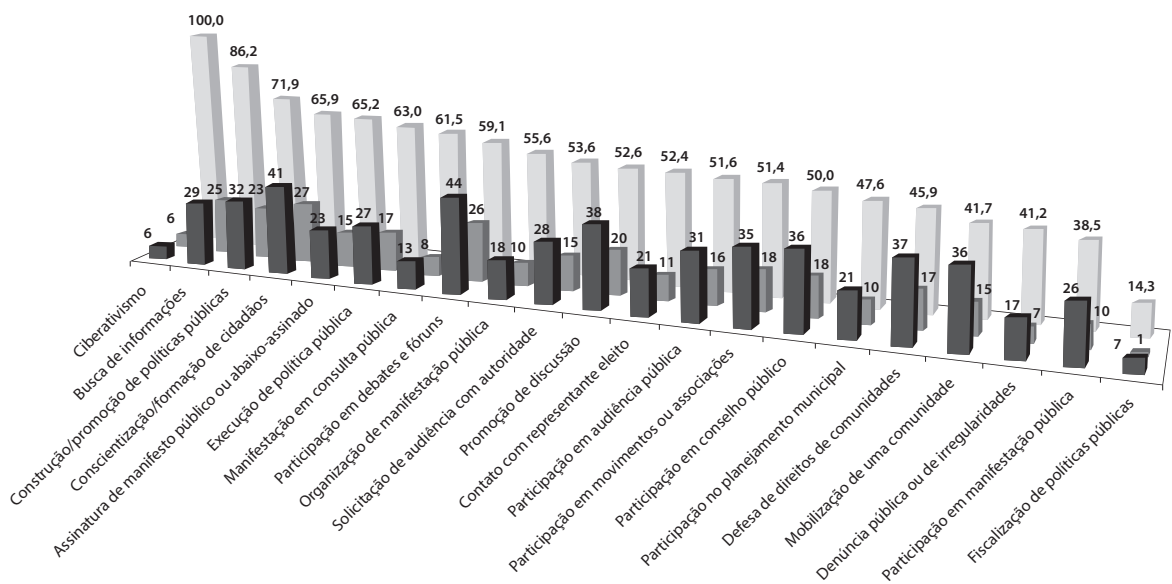

Fonte: Pesquisa dos autores, 2010

Quinze organizações disseram praticar ciberativismo, que é uma atividade relacionada ao uso de meios eletrônicos para organizar e mobilizar as pessoas em torno de uma causa. Ainda que seja discutível se de fato metade das organizações se valha dos recursos tenológicos com esse fim, já que muitas têm sítios eletrônicos com aspecto meramente informativo de suas ações, deve-se considerar o fato de que muitas delas estão diversificando as ferramentas que mobilizam para esse fim: das 30, nove mantêm blogs e 15 estão em redes sociais online. Também aparecem, porém com menos intensidade, mecanismos como chats, teleconferências e aplicativos como o Skype. A pesquisa de Pereira (2011, p. 14) encontrou indicadores semelhantes:

A Internet pode colaborar com o processo de mobilização através de boletins, e-mails, listas de discussão, blogs, twitters e sites. As redes telemáticas se baseiam principalmente em práticas descentralizadas entre as entidades, suas bases e os militantes internautas ocasionais, através da construção de um espaço cooperativo que oferece informações vindas das mais variadas fontes e que pode vir a enriquecer as práticas coletivas. 
No levantamento realizado em 2010, apenas 55,6\% das OSC que organizavam manifestações, utilizavam a internet de alguma forma. Atualmente, observa-se que todas se valem da plataforma como meio para mobilizar grupos em torno das manifestações. Na cauda de organizações ao redor do mundo que vêm empregando a internet - e, em especial, as redes digitais - para mobilizar para manifestações, todas as 10 organizações que atuam nessa forma de participação política, utilizam os recursos digitais para tal fim. No momento do levantamento de dados para este trabalho (junho de 2013), aconteciam manifestações em todo o Brasil que reuniam, em um único dia, somando-se os participantes de todas elas, mais de um milhão de pessoas. Essa grandiosidade e capilaridade das ações só foi possível pela apropriação das redes sociais online: não há um centro organizador das ações, há sim uma diversidade de movimentos sociais, grupos e também cidadãos não ligados a eles que tomam conhecimento da situação, divulgam informações e se mobilizam espontaneamente a partir das redes. Características da internet como baixo custo, rápida disseminação da informação e amplo alcance a tornaram uma ferramenta poderosa para mobilizar, organizar e maximizar a atuação dessas organizações:

[...] o poder integrador das páginas web e do universo que formavam trouxe para a comunicação distribuída a reunião dos diferentes movimentos em ações coletivas, seja para empreender uma luta comum, seja para construir uma atividade comum. [...] Nasce a guerra em rede (netwar), que permite aos movimentos sociais lutarem vantajosamente contra Estados e corporações. O movimento zapatista, nascido em 1994, será o principal exemplo desse poder e a principal escola de aprendizado para ONG e movimentos sociais. (ANTOUN, 2008, p. 16)

Como fontes de informação, os canais disponibilizados na internet tornaram-se os preferidos por quase todas as organizações. A proximidade entre informação e participação política fica evidenciada ao se constatar que 26 das 27 organizações que reconhecem essa relação, valem-se da internet como plataforma de acesso. Para além do acesso, no 
entanto, vale destacar outro uso da Internet pelas OSC que é a contribuição que têm dado na gestão e disseminação de informação política para públicos com determinado recorte de interesse. Como alguns autores (BOBBIO, 1997; MAIA, 2008) vêm reportando, é improvável que todos os cidadãos tenham um interesse ativo em participar de todos os assuntos públicos, então pode ser de grande valia encontrar esses assuntos minimamente organizados e com linhas de ação projetadas quando e para os que se interessam.

Os movimentos sociais têm como importante diretiva de ação a reapropriação dos códigos para remeter à realidade. Para isso, recorrem à produção e publicização de informação e/ou contra-informação, de modo a potencializar sua ação política, fato que pode ser notado na presença de inúmeros websites dedicados a campanhas globais de caráter ambientalista, humanista, pacifista ou econômico. (REIS, MARTINS, 2009)

Por outro lado, a internet possibilita uma individualização das informações acessadas, à medida que as pessoas podem selecionar somente os pontos de vista convergentes com os seus, o que enfraquece os ideais republicanos de exposição do cidadão a múltiplas facetas e motivações. (EISENBERG, 2003) Além disso, com a profusão do uso de redes sociais online, as informações passam a circular restritamente, fora dos padrões abertos que deram origem à web. Ou seja, o acesso à informação nessas redes sociais depende de login e "aceite" do outro, levando ao cerceamento do compartilhamento de conteúdo, o que vai contra o próprio princípio da internet de livre circulação:

A se continuar a existência de uma passividade acrítica na Web, criadores/usuários poderão ficar cada vez mais dependentes de plataformas e recursos dispostos em 'ilhas', sem a mesma ubiquidade promovida nos primórdios da internet e da Web. (VILARIM, 2013)

Embora a participação em movimentos ou associações não esteja entre as principais formas de participação política assim consideradas pelas organizações (18 delas), é visível seu interesse (17) em manter articulações, seja com outras congêneres, seja com aquelas do seu en- 
torno, via recursos digitais. As principais justificativas para o emprego da tecnologia estão na facilidade e economia para encontrar e manter a comunicação com pares, utilizando ferramentas e aplicativos como chats, WhatsApp e correio eletrônico, este, ainda, o mais utilizado. O depoimento é ilustrativo das afirmações:

A [organização] tem um papel de intermediar temas polêmicos como o movimento gay, o movimento negro[...] a igreja não apoia o aborto, o movimento feminista apoia, às vezes recebemos críticas pesadas, mas mentemos a nossa posição de intermediar e promover o diálogo entre as diferenças. [...] A internet viabilizou uma maior atuação no panorama nacional e internacional, podemos publicar mais para fora, por exemplo no caso dos quilomboas tivemos resposta de outros países. (COM)

Há também um aspecto relacionado a uma conjuntura local: com o Brasil ocupando a terceira posição entre os países em usuários do Facebook e a necessidade premente das OSC de estreitar laços com parceiros, colaboradores e sociedade civil para manterem-se competitivas, apresenta-se uma convergência entre um contexto cultural que valoriza a participação em redes sociais on-line - o que impulsiona as organizações para esse ambiente que, por sua vez, facilita enormemente a divulgação de ações e o compartilhamento de experiências e vivências - e os objetivos institucionais que reclamam visibilidade e aceitação social.

Com relação aos demais usos políticos, as organizações vão experimentando os recursos tecnológicos como aliados para divulgar e buscar apoio para suas causas, para abrir espaços de discussão e também na tentativa de mobilizar as pessoas para participar de ações, tanto no mundo virtual como no real. Portanto, tendem a usar ações híbridas - ações on-line e off-line - para aumentar o alcance de suas propostas:

A [organização] sempre foi avançada no uso da tecnologia. Estamos muito on-line, melhorando a nossa linguagem para atingir o público de uma forma geral, principalmente por causa da captação de recursos, inclusive com as redes sociais, com estratégias de mobilização que nós usamos para advogar os direitos das organizações que a gente apoia. (COM) 
Em suma, o emprego da internet no contexto da atuação política de organizações da sociedade civil, está intimamente relacionado à comunicação, obtenção e/ou busca de informação e visibilidade dos serviços e ações políticas desenvolvidas. Nesta pesquisa, contudo, foram observados empregos mais específicos, explicitados na emergência do uso de redes sociais eletrônicas, na prestação de contas nos websites e na utilização da internet para a captação de recursos.

Junto ao desenvolvimento das tecnologias e recursos informacionais e comunicacionais está a tendente migração das atividades humanas para os espaços digitais que compõem o ciberespaço. As organizações da sociedade civil parecem ter visto nesta tendência uma oportunidade de potencializar sua atuação política e social perante esta sociedade mais conectada à internet.

\section{CONCLUSÃO}

Os resultados permitem concluir que a internet por si só não impulsiona a participação política, visto que atua de forma complementar, mas potencializa a atuação já efetivada pelas OSC. Isto se coaduna com as conclusões de Norris (2001) em suas pesquisas com amostras de grupos sociais nos Estados Unidos e na Europa, nas quais observou que a internet não mobilizava grupos inativos, mas reforçava as tendências pré-existentes em participação política.

Em qualquer caso, a apropriação da internet pelas organizações de sociedade civil pode ser entendida como a incorporação de uma nova plataforma tecnológica que vai além de uma mera ferramenta: a internet tem representado um ambiente de informação diversificada e comunicação distribuída, uma alternativa relevante à informação massificada e à comunicação unilateral. Ela estabelece para as OSC um locus adequado ao fortalecimento da participação política.

Merece destaque a ênfase que as ferramentas digitais ganharam na atuação das organizações quando se comparam os dados levantados em 2010 e em 2013. Em três anos, essas ferramentas saíram da posição de "opção" para se tornarem uma necessidade quando se fala em acesso à informação e comunicação para as OSC. Vinte e sete de- 
las $(84,4 \%)$ indicaram a busca de informação entre as atividades que empreendem a fim de participarem dos processos sociais. Trata-se de uma vinculação presente nos modelos teóricos da democracia, e que nesta pesquisa encontrou reflexo nos dados empíricos, ou seja, está muito presente no discurso das OSC o entendimento de que precisam estar bem informadas para compreender a sociedade e buscar soluções para seus problemas. Da mesma forma, há a compreensão de que nos espaços públicos de que participam, precisam fazer intervenções com base na leitura do cenário e, portanto, mais uma vez, munidas de informações seguras, abrangentes e relevantes.

Percebe-se que a participação política torna-se cada vez mais híbrida, uma vez que utilizando os espaços on-line e off-line, as OSC integram várias mídias para interagir com a sociedade. A capacidade de mobilizar os recursos da internet para estabelecer e manter comunicação, conseguir cooperação e organizar manifestações é, portanto, um diferencial na atuação política recente das OSC. Contudo, não há indícios de que a internet por si só impulsionou a participação política: está mais do que claro que ela atua de forma a complementar a motivação política já existente na organização, isto é, ela é uma ferramenta que potencializa as ações desenvolvidas pelas organizações da sociedade civil.

\section{REFERÊNCIAS}

AKUTSU, L.; PINHO, J. A. G. Sociedade da informação, accountability e democracia delegativa: investigação em portais de governo no Brasil. RAP, v. 36, n. 5, set./out. 2002.

ALMEIDA, G. W. D. Participação política e democracia no Brasil. In: CONGRESSO BRASILEIRO DE CIÊNCIAS DA COMUNICAÇÃO, 33., 2010, Caxias do Sul. Anais... São Paulo: Sociedade Brasileira de Estudos Interdisciplinares da Comunicação, 2010. Disponível em:<http://www. intercom.org.br/papers/nacionais/2010/resumos/R5-1192-1.pdf>. Acesso em: 2 out. 2011.

ANTOUN, H. De uma teia à outra: a explosão do comum e o surgimento da vigilância participativa. In: ANTOUN, H. (Org.). Web 2.o: participação 
e vigilância na era da comunicação distribuída. Rio de Janeiro: Mauad X, 2008. p. 11-28.

BOBBIO, N. O futuro da democracia: uma defesa das regras do jogo. 6. ed. Rio de Janeiro: Paz e Terra, 1997.

BORGES, J. O uso da internet por organizações da sociedade civil enquanto atores cívicos. Revista Fronteiras, São Leopoldo, v. 14, n. 2 , p. 121-132, maio/ago. 2012. Disponível em: < http://revistas.unisinos.br/ index.php/fronteiras/article/view/fem.2012.142.06/997>

BORGES, J. Participação política, internet e competências infocomunicacionais: evidências a partir de organizações da sociedade civil de Salvador. Salvador: Edufba, 2013.

BORGES, J. et al. Competências infocomunicacionais: um conceito em desenvolvimento. Tendências da Pesquisa Brasileira em Ciência da Informação, v. 5, p. 10, 2013.

BORGES, J.; BRANDÃO, G.; MARTINS, G. Competências em comunicação: observação em organizações da sociedade ciivil de Salvador. Revista Comunicando, v. 2, p. 320-333, 2013.

BORGES, J.; JAMBEIRO, O. A internet na participação política de organizações da sociedade civil. In: PINHO, J. A. G. (Org.). Estado, sociedade e interações digitais: expectativas democráticas. Salvador: Edufba, 2012a. p. 41-62.

BORGES, J.; JAMBEIRO, O. Participação política de organizações da sociedade civil de Salvador. Verso e Reverso, v. 26, n. 61, p. 2-14, jan./ abr. 2012b. Disponível em: <http://revistas.unisinos.br/index.php/ versoereverso/article/viewFile/ver.2012.26.61.01/732>.

BORGES, J.; LESSA, B. ; BRANDÃO, G. Apropriação da internet na atuação política de organizações da sociedade civil de Salvador. Redes. com - Revista de Estudios para el Desarrollo Social de la Comunicación, v. 8, p. 107-129, 2013.

BUCY, E.; GREGSON, K. Media participation: a legitimizing mechanism of mass democracy. New Media at Society, v. 3, n. 3, p. 357-380, 2001.

CHRISSAFIS, T.; ROHEN, M. European eParticipation developments. JeDEM, v. 2, n. 2, p. 89-98, 2009 . 
DIMAGGIO, P. et al. Social implications of the Internet. Annual Review of Sociology, v. 27, p. 307-336, 2001.

EISENBERG, J. Internet, Democracia e República. Revista de Ciências Sociais, Rio de Janeiro, v. 46, n. 3, p. 491-511, 2003.

GENNARO, C. D.; DUTTON, W. The Internet and the public: online and offline political participation in the United Kingdom. Parliamentary Affairs, v. 59, n. 2, p. 299-313, 2006.

GEPICC. Grupo de Estudos de Políticas de Informação, Comunicações e Conhecimento. Salvador: UFBA, 2013. Disponível em: <http://www. gepicc.ufba.br/>.

GOMES, W. A democracia digital e o problema da participação civil na decisão política. Revista Fronteiras, São Leopoldo, v. 7, n. 3, p. 214-222, set./dez. 2005 a.

GOMES, W. Participação política online: questões e hipóteses de trabalho. In: MAIA, R. C. M. et al. (Org.). Internet e participação política no Brasil. Porto Alegre: Sulina, 2011. Cap.1. p. 19-45. (Cibercultura).

JAMBEIRO, O.; BORGES, J. Internet, participação política e organizações da sociedade civil. Revista Eco-Pós, Rio de Janeiro, v. 13, p. 124-145, 2010. Disponível em: < https://revistas.ufrj.br/index.php/ eco_pos/article/view/889>.

JENKINS, H. Cultura da convergência. São Paulo: Aleph, 2008.

JOHNSTON, P. Transforming government's policy-making processes. JeDEM, v. 2, n. 2, p. 162-169, 2009.

KUMAR, K. A Sociedade de Informação. In: KUMAR, K. (Org.). Da sociedade pós-Industrial à pós-moderna: novas teorias sobre o mundo contemporãneo. Rio de Janeiro: Jorge Zahar, 2006. p. 45-74.

MACINTOSH, A.; WHYTE, A. Evaluating how eparticipation changes local democracy. In: EGOBERNMENT WORKSHOP'o6 (EGOVo6), 6., 2006 , West London. Anais... London: Brunel University, 2006. Disponível em:<http://www.iseing.org/egov/eGOVo6/Accepted\%20 Papers/624/CRC/Evaluation\%2oof\%2oeParticipationv-v2-submitted. pdf>. Acesso em: 2 out. 2011. 
MAIA, R. Redes cívicas e internet: efeitos democráticos do associativismo. In: GOMES, W; MAIA, R. C. M. (Org.). Comunicação e democracia: problemas \& perspectivas. São Paulo: Paulus, 2008. p. 327-348.

MAIA, R. Internet e esfera civil: limites e alcances da participação política. In: MAIA, R. C. M. et al. (Org.). Internet e participação política no Brasil. Porto Alegre: Sulina, 2011. Cap.2. p. 47-91.

NUNES, M. V. Novas tecnologias e cidadania: a internet como fator de politização ou de adequação das comunidades excluídas ao sistema produtivo? In: CONGRESSO BRASILEIRO DE CIÊNCIAS DA COMUNICAÇÃO, 30., 2007, Santos. Anais... São Paulo: Sociedade Brasileira de Estudos Interdisciplinares da Comunicação, 2007. Disponível em:<http://www.intercom.org.br/papers/nacionais/2007/ resumos/Ro113-1.pdf>. Acesso em: 2 out. 2011.

PEREIRA, M. A. Internet e mobilização política: os movimentos sociais na era digital. In: ENCONTRO DA COMPOLÍTICA, 4, 2011, Rio de Janeiro. Anais... Rio de Janeiro: Associação Brasileira de Pesquisadores em Comunicação e Política, 2011. Disponível em:<http://www. compolitica.org/home/wp-content/uploads/2011/03/Marcus-Abilio. pdf>. Acesso em: 2 out. 2011.

REIS, A. S.; MARTINS, A. A. L. Movimentos sociais, informação e mediação: uma visão dialética das negociações de sentido e poder. DataGramaZero - Revista de Ciência da Informação, Rio de Janeiro, v. 10, n. 5, out. 2009. Disponível em:<http://www.dgz.org.br/outo9/Art_04. htm>. Acesso em: 27 set. 2011.

RONCA, A. C. C.; COSTA, R. A construção de uma democracia cognitiva. São Paulo em Perspectiva, v. 16, n. 4, p. 24-29, 2002.

SAMPAIO, R. Participação política e os potenciais democráticos da internet. Revista Debates, v. 4, n. 1, p. 29-53, jan./jun. 2010.

SANTOS, B. Democratizar a democracia: os caminhos da democracia participativa. Rio de Janeiro: Civilização Brasileira, 2002.

VILARIM, G. de O. Produção de conhecimento na web e passividade acrítica nas novas plataformas de software. In: ENCONTRO NACIONAL DE PESQIOSA E, CIÊNCIA DA INFORMAÇÃO, 13., Florianópolis. Anais... Florianópolis: Ancib, 2013. 
WOLTON, D. É preciso salvar a comunicação. Casal de Cambra: Caleidoscópio, 2006.

ZIBA, A. Technology choices and 'literacies' for eParticipation in Malawi. In: AVDIC, A. et al. (Org.). Understanding e Participation:

Contemporary PhD eParticipation Research in Europe. Örebro: Örebro University Library, 2007. p. 167-182. 


\section{ESTUDO DAS MUDANÇAS NOS PROCESSOS DE GESTÃO DE SISTEMAS DE INFORMAÇÃO PELA INCORPORAÇÃO DE ARTEFATOS DIGITAIS INTERATIVOS}

LEILA LAGE HUMES, NICOLAU REINHARD

INTRODUÇÃO

As organizações dependem, cada vez mais, das Tecnologias de Informação e Comunicação (TICs) para suporte a suas atividades. O avanço da tecnologia deu novo alento ao trabalho colaborativo, uma vez que, por meio do uso das TICs, tornou-se possível flexibilizar processos organizacionais e desenvolver projetos compartilhados com equipes alocadas em várias partes do mundo. Além disso, facilitou a troca de expertise entre times, uma vez que um especialista pode participar de várias equipes simultaneamente, podendo, portanto, participar de projetos distintos, desenvolvidos em várias partes do mundo.

Os diversos grupos de trabalho de uma organização, por sua vez, costumam adotar ferramentas distintas como meio de colaboração e comunicação entre seus membros (WATSON-MANHEIM; BELANGER, 2007), tornando mais complexa a solução de TI que permita a 
integração e o compartilhamento de informações entre equipes com atuação global.

Deve-se ressaltar também que a rápida disseminação de tecnologias digitais nas últimas décadas do século XX, deu origem a uma nova geração - os nativos digitais - termo cunhado por Prensky (2001) para designar uma geração que cresceu em um mundo cercado por tecnologias informativas, tendo fácil acesso a computadores conectados à Internet, videogames, telefones celulares e outras tecnologias de informação e comunicação disponíveis atualmente.

Segundo Prensky (2001), o ambiente no qual essa geração vive e a interação constante com esse ambiente provocaram mudanças na forma de pensar e processar informações. Essa nova geração tem o hábito de adquirir conhecimento, colaborando e interagindo, bem como a tendência de produzir informação e não apenas recebê-la, de encontrar a informação que lhe interessa e disponibilizá-la em rede. Entretanto, a maioria dos sistemas corporativos continua a ser projetada de forma tradicional, sem ferramentas que permitam fácil interação e colaboração entre equipes de trabalho dispersas geograficamente e sem a flexibilidade e facilidade de comunicação proporcionadas por artefatos digitais presentes em redes sociais.

Os sistemas de informação que permitem a construção colaborativa de conhecimento e a possibilidade de compartilhamento de informações, além da possibilidade de acesso de qualquer lugar, são casos de sistemas ubíquos. Esses sistemas, portanto, precisam ser projetados de forma diversa dos sistemas desenvolvidos no passado.

Quanto a pesquisas referentes a mudanças no projeto de desenvolvimento de sistemas de informação, destacam-se os estudos de Hanseth e colaboradores (1998) afirmando que as soluções de TI a serem desenvolvidas não podem ser projetadas de forma isolada e autônoma, como no passado, ou visando a atender a determinados públicos específicos e bem conhecidos. As novas soluções devem ser compatíveis com requisitos como a facilidade de integração e expansão de sistemas entre fronteiras organizacionais e geográficas e devem ser resultantes da integração de aplicações e artefatos técnicos, projetistas, organiza- 
ções e pessoas. Como consequência, esses sistemas estão sujeitos a influências culturais, sociais e, muitas vezes, a limitações impostas por tecnologia e ambientes diversos daqueles para os quais foram inicialmente projetados.

Tendo em vista a necessidade de integração entre sistemas, a mudança na forma de trabalho entre equipes e empresas, e visando incorporar novas facilidades de comunicação e interação demandadas por novas gerações que passaram a integrar a força de trabalho das empresas, justifica-se estudar como incorporar artefatos digitais a sistemas de informação e comunicação dedicados ao ensino e pesquisa, a empresas, ou mesmo à difusão de conhecimentos na sociedade. Essa incorporação traria como vantagens a sistematização dos processos de tomada de decisões, maior integração entre membros de equipes geograficamente dispersas e mais flexibilidade no compartilhamento de conhecimentos entre equipes.

\section{REVISÃO DE LITERATURA}

Artefatos digitais são intencionalmente incompletos e estão em constante mudança. (GARUD et al., 2008) De acordo com Kallinikos e colaboradores (2013), o fato de serem incompletos representa tanto uma oportunidade quanto um problema. Pode-se considerar uma oportunidade por não se limitar o conjunto de tarefas e links operacionais que um artefato pode acomodar, mas é um problema se for considerar a redução de controle sobre o artefato e o seu uso. Ainda segundo Kallinikos e colaboradores (2013), artefatos digitais têm uma ontologia ambivalente. Eles são objetos, embora falte a eles a amplitude e a estabilidade exibidas por itens tradicionais e dispositivos.

Ekbia (2009) preconiza que artefatos digitais (como blogs, wikis e perfis pessoais em redes sociais) carecem de uma identidade definida, uma condição decorrente da contínua mudança pela qual passam. O autor também os descreve como capazes de fomentar relacionamentos sociais, ao invés de se constituírem apenas em representação de algo fixo e imutável. Artefatos digitais como arquivos, imagens, filmes e vídeos são considerados por Kallinikos e Mariategui (2011) 
como fluidos e editáveis, frequentemente imersos em ambientes complexos, distribuídos e em constante mudança.

Outros autores como Yoo e Gothenburg (2010) e Yoo, Henfridsson e Lyytinen (2010) descrevem artefatos digitais como reprogramáveis e entidades autorreferenciáveis, cuja constituição permite a decomposição, a adaptação, a rastreabilidade e outras propriedades que facilitam a interoperabilidade. À medida que esses artefatos se difundem, essas propriedades permitem que eles sejam incorporados a infraestruturas digitais e se tornem independentes de serviços ou dispositivos instalados.

As principais dimensões apontadas por Kallinikos e colaboradores (2010) para artefatos digitais são:

- editabilidade - podem ser modificados ou atualizados continuamente e sistematicamente, seja pelo rearranjo de elementos, excluindo ou adicionando elementos ou mesmo modificando algumas das funções de elementos individuais.

- abertos e reprogramáveis - são acessíveis e modificáveis por um programa, impingindo versatilidade ao seu uso, uma vez que não estão sujeitos a um comportamento pré-determinado. (KALLINIKOS; MARIATEGUI, 2011)

- interatividade - oferecem alternativas de escolha quanto à ativação de funções ou exploração de itens de informação inclusos nos artefatos.

- acessibilidade - podem ser acessados, modificados ou recombinados por meio de outros objetos digitais (exemplos: softwares de edição de imagens), podendo ser considerados, em princípio, abertos e reprogramáveis.

- disseminação - não são limitados por fronteiras físicas ou propriedades que limitem o reuso ou a recombinação, podendo ser modificados ou recombinados facilmente por meio de programas computacionais que tornam os objetos digitais fluidos e transformáveis.

Segundo Kallinikos e colaboradores (2010), as implicações técnicas, comportamentais e organizacionais decorrentes das propriedades 
dos artefatos digitais, a natureza fluida do conteúdo digital e a arquitetura de relações presentes na criação desses elementos demandam uma mudança na agenda de pesquisa de sistemas de informação. Ainda segundo os mesmos autores, artefatos digitais devem ser estudados quanto a requisitos técnicos e organizacionais, de forma que se possa garantir a interoperabilidade e o crescimento desses elementos, pois a sua utilização implica na possibilidade de aliar tecnologia a práticas sociais, podendo-se citar como exemplos dessa comunhão o uso do Youtube, Wikipedia e Facebook incorporados em sistemas organizacionais.

Artefatos digitais tornam-se meios importantes de comunicação e expressão para a nova geração, os nativos digitais. Na verdade, tratase de uma geração que não faz uso de tecnologia de forma passiva, e sim como um participante ativo, criando conteúdo e páginas pessoais, usando blogs, wikis, mensagens de texto e postando vídeos, enfim, usando a tecnologia tanto em sua vida pessoal quanto para o desempenho de suas tarefas num contexto organizacional. (VODANOVICH; SUNDARAM; MYERS, 2010) Ou seja, o nativo digital não é apenas um observador, mas espera ter chance de interagir dentro de uma rede, de expor suas dúvidas e compartilhar seus conhecimentos com a comunidade, enfim, poder trabalhar de uma forma colaborativa com seus pares.

Pelo exposto acima, é possível depreender que existem novas demandas da sociedade relativas ao acesso ao conhecimento. Entretanto, essas novas demandas só podem ser atendidas em sistemas que estejam preparados para incorporar artefatos digitais interativos, para os quais não exista previsão de incorporação nos sistemas de informação projetados de forma tradicional.

De acordo com Vodanovich, Sundaram e Myers (2010), sistemas de informação tradicionais contribuem para melhorar a eficiência e a efetividade das organizações. Esses sistemas foram projetados para atender aos imigrantes digitais para os quais a funcionalidade era de suma importância. Para os nativos digitais, entretanto, interatividade, usabilidade, flexibilidade e conectividade são tão importantes quanto funcionalidade. 
Autores como Yoo e Gothenburg (2010) propõem um framework que inclui artefatos, atores, espaço e tempo. Os elementos espaço e tempo definem "onde" e "quando" (o contexto) os atores interagem com os artefatos. A partir dessas definições, Vodanovich, Sundaram e Myers (2010) propuseram quatro dimensões, consideradas pelos autores como relevantes para se enquadrar os nativos digitais em relação aos sistemas ubíquos (imigrantes digitais versus nativos digitais), sistemas (sistemas de informação tradicionais versus sistemas de informação ubíquos), atividades (profissionais versus pessoais) e contexto (trabalho versus vida social). Esquematicamente, essas dimensões podem ser representadas pelo diagrama a seguir:

Quadro 1 - Dimensões representando nativos digitais e o contexto de Sistemas de Informação Ubíquos

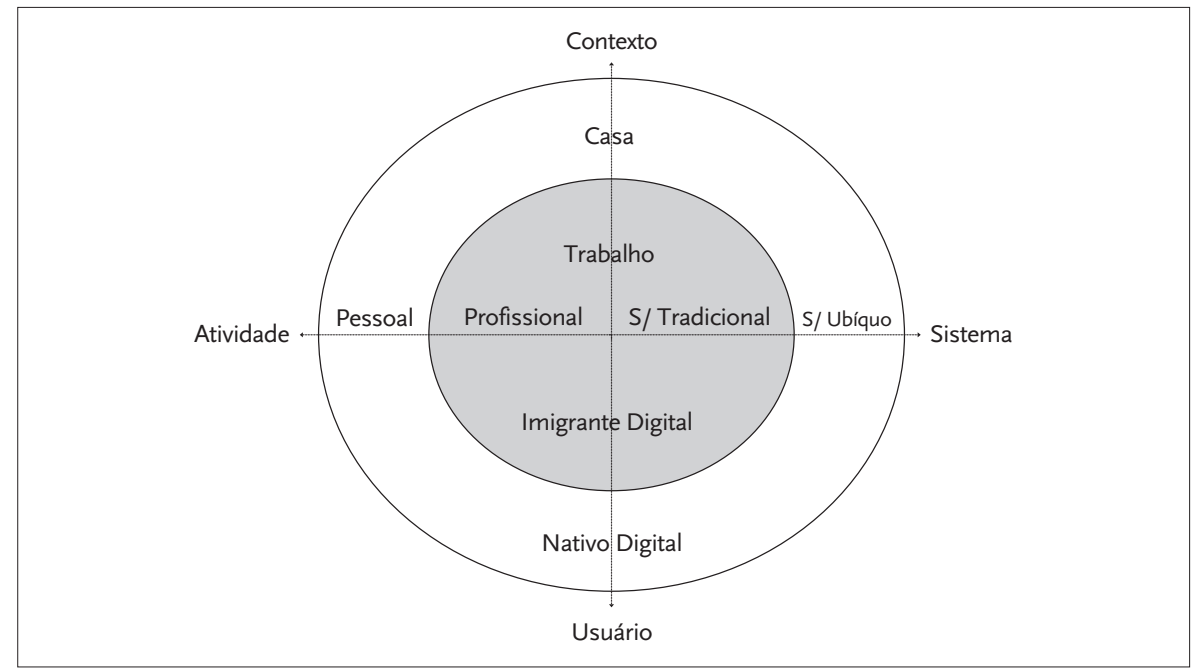

Fonte: Vodanovich, Sundaram e Myers (2010).

Como exposto anteriormente, as novas soluções devem ser resultantes da integração de aplicações e artefatos técnicos, projetistas, organizações e pessoas. Devido a esses condicionantes, estão sujeitas a influências culturais, políticas e sociais. Portanto, para o projeto de sistemas ubíquos, é preciso lançar mão de referencial teórico desenvolvido também por pesquisadores dedicados ao estudo de redes digitais e 
suas implicações no contexto cultural e social. Passamos, em seguida, a apresentar o referencial teórico desenvolvido por pesquisadores que se dedicam ao estudo dessas redes digitais e às mudanças provocadas na sociedade pela propagação das redes.

Di Felice (2012) afirma que as redes digitais representaram uma inovação no mundo das comunicações e uma verdadeira revolução na sociedade, com mudanças profundas na forma de trabalho e modo de vida das pessoas. O autor diz que o caráter extraurbano da inovação é uma constante na tradição do Ocidente. Segundo o autor, as redes digitais se desenvolvem por meio da experimentação e em um ambiente de colaboração e compartilhamento entre grupos. Nos parágrafos seguintes, tecem-se algumas considerações desse mesmo autor sobre a forma de como a inovação se propagou ao longo do tempo, lançando uma visão mais ampla sobre o movimento de propagação das redes digitais e a sua importância para a sociedade.

$\mathrm{Na}$ antiga Grécia, os pensadores que começavam a desenvolver um pensamento racional, diferente das explicações provenientes dos mitos, saíam de suas cidades para empreender uma vida "apólita" (nômade), em constante peregrinação, vendendo seus conhecimentos para sobreviver.

Da mesma forma, lembra o autor, na Europa tardo-medieval, os muros das cidades marcavam o limite entre a ordem e a desordem, os territórios extraurbanos eram considerados lugares perigosos, onde se multiplicavam os acontecimentos ilegais e macabros. Entretanto, era justamente no espaço extrapolis que se originavam os movimentos da transformação e a inovação. Fora da cidade, estavam os cemitérios em torno dos quais circulavam os "outsiders" expulsos da cidade e todos os indesejáveis - os mortos-vivos, as bruxas, os pestilentos e os bandos de criminosos. A ausência de higiene, as doenças e a proximidade dos cemitérios constituíam o contexto de um mundo obscuro e contaminado, perigoso, uma terra de ninguém, espaço de atuação dos imorais e dos ladrões, sendo que no interior dos muros da cidade reinavam a ordem e a lei. 
Fora da cidade, a ausência de uma separação espacial, de ordem, de uma hierarquia social clara, incrementava a velocidade de contaminação, espalhando doenças e comportamentos imorais. No entanto, era justamente nestes lugares insalubres, nos burgos insalubres, que residiam os excluídos, os “outsiders" que não eram nem camponeses, nem proprietários de terras, nem militares, nem religiosos e nos quais esses excluídos começam a construir seu próprio futuro a partir de trocas de mercadorias, substituindo a ordem social, que era baseada na ordem dogmática e religiosa, pelo princípio da racionalidade econômica e contratual. Longe dos muros aconchegantes da cidade é que ocorriam o processo de transformação e o advento do novo, produzido pelos "outsiders" burgueses, portadores de novos valores, e de um novo tipo de subjetividade. Por meio da troca de mercadorias e com a mediação de moedas consideradas marginais pela sociedade feudal é que surgiu uma nova economia e uma nova sociedade.

O autor estabelece um paralelo com uma época mais recente, citando acontecimentos que causaram uma ruptura em tradições e costumes da sociedade. O primeiro deles foi o advento da eletricidade que, por si só, foi capaz de causar enormes mudanças na economia mundial pelo leque de oportunidades que surgiu na área de produção, de consumo, de mudança de hábitos e na sociedade em geral. Outro veículo de transformação na sociedade foi a invenção das mídias de massa, como o cinema, a TV e o rádio que permitiram a divulgação de novos costumes, da moda e das músicas. Com isso, os novos estilos de vida, as novas formas de participação de massa, os conflitos sociais e a vontade de mudanças encontraram nas mídias sociais não somente veículos de sua própria difusão, mas espaços experimentais de elaboração de novas estéticas e tendências.

A transgressão, a luta contra a discriminação social, a luta pela emancipação feminina e a crítica ao autoritarismo encontravam nas imagens do cinema e na música uma forma de expressão da transgressão.

A mídia de massa foi o espaço impuro de reprodução de todos os estilos alternativos e dos conflitos entre o existente e o alternativo proposto, 
ou seja, expressou uma crítica à sociedade industrial e à cultura autoritária e se constituiu em novos espaços de incubação e de reprodução, espalhando os efeitos de uma revolução cultural que se alastrou pelas sociedades ocidentais.

Por fim, Di Felice (2012) destaca que na atualidade, o espaço impuro é a Internet. As redes criaram uma nova forma de difusão de ideias dos "outsiders", geralmente, os adolescentes e jovens cientistas. A interação entre as novas gerações que elegeram a rede como meio de expressão vem transformando o mundo, provocando mais uma vez, a desaprovação e a crítica dos intelectuais, dos pedagogos e dos pretensos defensores do bem comum. Os games, os sites e as redes sociais tornaram-se os novos burgos, os novos lugares insalubres, os novos cemitérios, em torno dos quais se espalham os vírus e as bactérias que ameaçam as cidades e suas instituições.

Nas redes, consideradas territórios informativos abertos, foi possível recortar espaços de criação e de expressão. Os jovens e, aos poucos, uma geração inteira começaram a desenvolver suas atividades sociais e suas funções por meio da interação, elegendo a rede como o espaço de expressão e de inovação.

A sinergia entre a Internet e as novas gerações tem provocado transformações culturais qualitativas, que exprimem uma nova cultura de participação social global, difundindo práticas de interação colaborativas, de transparência, além da exigência de participação ativa, que supera os limites da esfera opinativa e da participação eleitoral.

Simultaneamente, o autor destaca que houve uma transformação no modo de produção e distribuição de informações, pois se considerava que a propagação ocorria de uma forma linear e unidirecional, na qual se admitia apenas a transmissão de um emissor (A) para um ou mais receptores (B). Nessa passagem, não se considerava a existência de dissonância entre emissor e receptor, ou seja, supunha-se que todo conteúdo transmitido era integralmente recebido e entendido pelo receptor. O modelo anterior da transmissão de informações entre Emissor e Receptor pode ser sumarizado pelo Quadro 2, a seguir: 
Quadro 2 - Modelo anterior de Transmissão de Informações

Transmissão de Informações

Modelo anterior

Emissor $\rightarrow$ Receptor

Esse modelo pressupunha:

- Assimilação integral da mensagem transmitida, independentemente do público ao qual ela se destinava. Estabelecia-se uma relação direta entre a mensagem enviada e o comportamento que ela desejava provocar, sem levar em conta as diferenças comunicativas existentes entre os diversos meios ou a diversidade sociocultural da audiência.

- Controle da produção e transmissão nas mãos do emissor, desconsiderando qualquer possibilidade de resposta por parte dos destinatários; uma massa passiva e anônima, incapaz de responder individualmente e isoladamente às manipulações e persuasões advindas da mensagem enviada.

- As mensagens eram transmitidas como se não houvesse deformação ou interferência de tipo contextual ou interpretativo, no seu percurso, do emissor ao destinatário.

- Inexistência de assimetria entre emissor e receptor

Posteriormente, admitiu-se que a transmissão de informações ocorre de uma forma reticular e dialógica, podendo ser propagada e modificada ao ser difundida pelas redes, ou seja, essa forma de propagação significou o advento de uma nova forma de complexidade. Da mesma forma, deu origem à necessidade de se pensar, de forma complexa e não linear, a necessidade de se procurar descrições mais articuladas dos fenômenos e da realidade em geral dentro das próprias ciências, após um conjunto de descobertas na matemática, na geometria e na física, no início do século XX.

Atualmente, a ação comunicativa assume uma nova dimensão, pois houve um incremento da complexidade interativa entre os emissores 
da mensagem e os destinatários pretendidos. Há um deslocamento da produção exclusiva do conteúdo comunicado, do emissor em relação ao espaço interindividual até a indistinção entre esses papéis comunicativos, pois com o advento da Web 2.0, a mensagem assumiu novas formas: o conhecimento passou a ser construído colaborativamente entre pares, perdendo parte de seu caráter apenas disseminativo e assumindo o caráter de construção colaborativa do conhecimento.

Com a alternância de papéis entre emissor e receptor, há uma mudança na construção do conteúdo: o emissor, que anteriormente se baseava nas suas próprias percepções sobre o destinatário para determinar o conteúdo da mensagem a ser transmitida, passou a assumir uma nova atitude frente ao conteúdo a ser transmitido, uma vez que emissor e destinatário se tornam interdependentes na construção colaborativa de conhecimento. Nesse cenário, a web 2.0 (possível graças à conexão de alta velocidade que permitiu a veiculação via web de informações em todos os formatos - áudio, vídeo, imagens, etc) para a construção de conteúdos em plataformas colaborativas passou a representar uma alternativa ao modelo emissor-receptor.

As considerações acima permitem estabelecer uma comparação entre sistemas de informação projetados de forma tradicional e a comunicação unidirecional emissor-receptor, pois esses sistemas partem dos mesmos pressupostos do assumido nas comunicações, ou seja, pressupõe-se que o projetista de sistemas tenha perfeito conhecimento sobre as demandas do destinatário e o sistema será plenamente compreendido e utilizado conforme projetado, incorporando todas as funcionalidades previstas, não se prevendo nenhum tipo de dissonância entre o desenvolvedor do sistema e o público ao qual ele se destina. No projeto convencional de sistemas, não se leva em conta o perfil da nova geração que prefere trabalhar com sistemas ubíquos similares aos que costumam utilizar em sua vida pessoal. Da mesma forma, não se pressupõe a possibilidade de incorporação de artefatos digitais como vídeos, wikis e blogs em sua arquitetura, embora tais artefatos sejam essenciais para a flexibilização da transmissão de conteúdo e para o compartilhamento e construção colaborativa de conhecimentos entre pares. 
Levando-se em conta o apontado na comparação acima, pode-se estudar a incorporação de artefatos digitais em sistemas de informação, uma vez que aplicações em várias áreas do conhecimento demandam a flexibilização no projeto de sistemas de informação, seja para uso em redes interativas digitais, seja criando novas formas e canais de comunicação e divulgação de conhecimentos.

\section{TEMAS PROPOSTOS PARA PESQUISA}

Novas tecnologias digitais ubíquas provocaram mudanças nos produtos e serviços oferecidos pelas empresas à sociedade. Por sua vez, uma nova cultura tecnológica e de comunicação prevalece no cotidiano das novas gerações que vivem em contextos sociais e midiáticos digitais, demandando mudanças no modelo de comunicação e gestão das organizações. Nesse cenário, a incorporação de artefatos digitais interativos a sistemas de informação passou a ser uma demanda tanto da sociedade quanto dos novos integrantes das organizações, os nativos digitais. Essa constatação remete à questão que deve nortear o desenvolvimento de sistemas que incorporem artefatos digitais interativos, ou seja: Quais são as diretrizes a serem estabelecidas para o projeto de sistemas de informação de forma a permitir a integração de artefatos digitais interativos à sua estrutura?

MODELO DE PESQUISA PARA O DESENVOLVIMENTO DE SISTEMAS DE INFORMAÇÃO UBÍQUOS

A ampla adoção e uso de tecnologia da informação por empresas tornaram o relacionamento entre os sistemas de informação e a organização cada mais complexo. (ZAMMUTO et al., 2007) À medida que os sistemas de informação de uma empresa se tornam interconectados a maior parte das organizações enfrenta grandes desafios ao tentar controlar um conjunto de sistemas e tecnologias introduzidas ao longo dos anos para atender a diferentes propósitos. (CIBORRA; BRAA; CORDELLA, 2000) Como resultado, a efetividade de um sistema é condicionada pela base instalada e por arranjos sociotécnicos. (HENFRIDSSON; BYGSTAD, 2013) A base conceitual a ser utilizada 
para análise desses sistemas não pode ser a de um sistema único, pois as fronteiras entre sistemas intra e interorganizacionais tornam-se difusas. Além disso, sistemas de informação podem mudar ao longo do tempo, à medida que novos artefatos digitais são incorporados a esses sistemas, transformando-os, muitas vezes, em infraestruturas digitais. Portanto, não podemos estabelecer uma classificação rígida para sistemas de informação que incorporam artefatos digitais, uma vez que temos um continuum entre sistemas de informação e infraestruturas digitais, conforme ilustrado no Quadro 3.

$\mathrm{Na}$ literatura, o termo infraestrutura foi adotado como uma forma de englobar sistemas interconectados. Segundo Braa e colaboradores (2007), uma infraestrutura digital é uma coleção de componentes humanos e tecnológicos, redes, sistemas e processos que contribuem para o funcionamento de um sistema de informação, cuja evolução envolve elementos técnicos e sociais. Por sua vez, Lanzara (2009) adota o termo assemblages para definir infraestruturas de informação digitais, agregando a elas as regras, as práticas e os valores institucionais e organizacionais.

Quadro 3 - Classificação de arquiteturas de informação

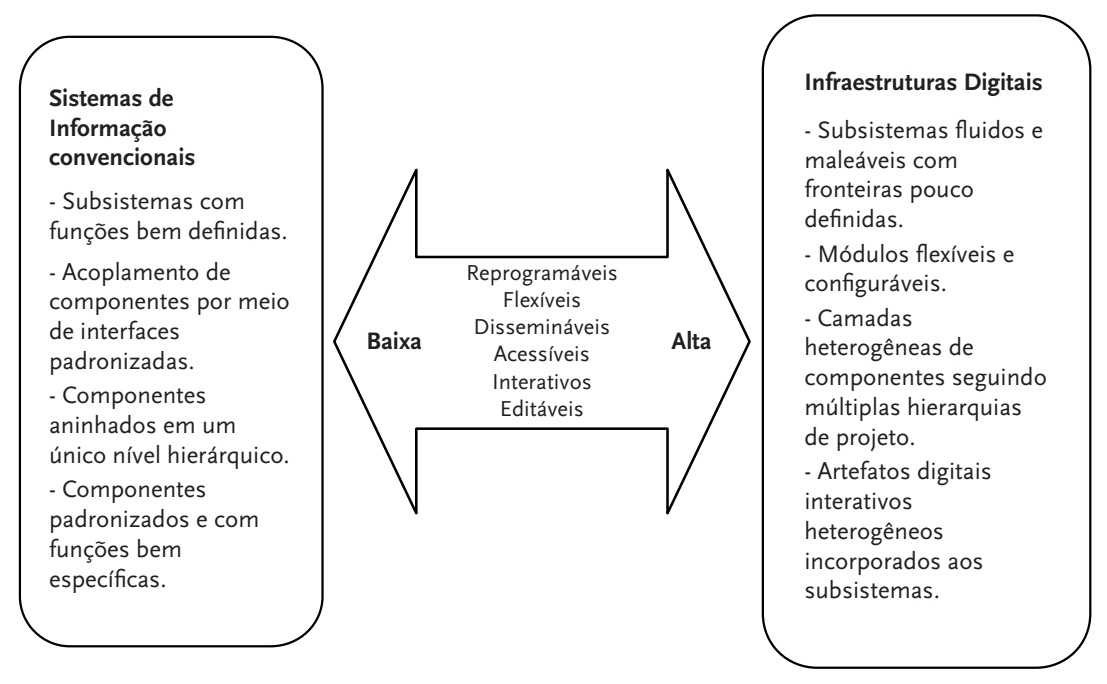

Fonte: adaptado de Yoo, Henfridsson e Lyytinen (2010). 
Com o intuito de pesquisar quais são os desafios a serem enfrentados no desenvolvimento de um sistema de informação devido à incorporação de artefatos digitais à sua estrutura, abordar-se-á um estudo de caso na área da Saúde. Esses sistemas são, muitas vezes, desenvolvidos pelo estabelecimento de parcerias entre universidades e órgãos do governo e são destinados a prover assistência e capacitação a profissionais de saúde que trabalham em lugares remotos.

Uma metodologia adequada para a análise do estudo de caso selecionado na área de Saúde é o "Design Science Research", utilizado em pesquisas na área de TI, em problemas que são considerados incompletos, contraditórios e com requisitos mutáveis (BROOKS JR, 1987, 1996; RITTEL; WEBER, 1984), ou seja, problemas caracterizados por:

- Requisitos instáveis e limitações baseadas em contextos ambientais pobremente definidos.

- Interações complexas entre subcomponentes do problema e a solução adotada.

- Inerente flexibilidade para mudar os processos do projeto e o projeto dos artefatos.

- Uma dependência crítica de habilidades cognitivas, por exemplo, criatividade, para produzir soluções efetivas.

- Uma dependência crítica de habilidade sociais, por exemplo, trabalho em grupo para produzir soluções efetivas.

\section{ESTUDO DE CASO}

O uso de recursos de tecnologia da informação e comunicação é muito relevante para a área da saúde, pois, por meio da utilização desses recursos, é possível prover atendimento e atenção médica a pessoas que vivem em áreas remotas, promover a troca de informações com agentes comunitários de saúde e cursos de capacitação a distância, bem como prover informações voltadas a públicos específicos, como crianças, adolescentes, comunidades indígenas, etc.

A possibilidade do uso de recursos de tecnologia da informação e comunicação na área da saúde deu origem a uma nova área do conhe- 
cimento, a e-Saúde (e-Health), definida pela Organização Mundial da Saúde (OMS) como o uso de TICs na área da saúde para o tratamento de pacientes, desenvolvimento de pesquisas, divulgação de conhecimentos, educação da força de trabalho e monitoramento de doenças e da saúde pública. Entretanto, sistemas para a área de e-Saúde são projetados prevendo o uso de artefatos digitais interativos como arquivos, imagens, filmes e vídeos, considerados por Kallinikos e Mariategui (2011) como fluidos e editáveis sujeitos, portanto, a constantes mudanças. Conforme ressaltado pelos autores, a flexibilidade apresentada por esses artefatos se contrapõe à instabilidade gerada pela sua incorporação a sistemas de informação, lançando novos desafios a serem enfrentados no desenvolvimento e na gestão desses sistemas.

O estudo de caso permite analisar as peculiaridades de sistemas de informação ubíquos desenvolvidos para a área da saúde e utilizados tanto por nativos digitais como por imigrantes digitais. $\mathrm{O}$ universo dessa pesquisa pode ser sumarizado pelo Quadro 4, a seguir.

Quadro 4 - Universo de pesquisa

\begin{tabular}{|l|c|c|}
\hline & SISTEMA TRADICIONAL & SISTEMA UBÍQUO \\
\hline Imigrante Digital & & $\mathrm{X}$ \\
\hline Nativo Digital & & $\mathrm{x}$ \\
\hline
\end{tabular}

Um caso de particular interesse é a área de Teleodontologia, em que podem ser estudadas as iniciativas do Núcleo de Teleodontologia da Faculdade de Odontologia da USP (NTO-FOUSP). Esse núcleo foi criado em 2007, marcando o início da participação da odontologia no Programa Telessaúde Brasil Redes, coordenado pela Secretaria de Gestão do Trabalho e da Educação na Saúde do Ministério da Saúde. O programa nacional busca integrar ensino e serviço, utilizando como ferramenta Novas Tecnologias de Informação e Comunicação (NTICs) para promover a Teleassistência e a Teleducação. Tais tecnologias podem apoiar ações educacionais e de assistência à saúde e, também, permitem a realização de teleconsultorias que consistem na troca de informações em saúde entre profissionais, a distância. 
A partir do ano 2000, dentistas passaram a integrar as Equipes de Saúde da Família articuladas pelo SUS. Segundo Haddad e colaboradores (2013), a inclusão da Odontologia no SUS introduziu uma nova demanda aos cursos de graduação, à medida que passou a exigir que os estudantes fossem preparados para enfrentar o desafio de trabalhar com equipes multiprofissionais e com serviços públicos e não apenas em consultórios particulares. Para melhor integrar a Odontologia, foi criada, em 2011, a Rede Nacional de Teleodontologia (RNTO), cujo objetivo é compartilhar experiências bem-sucedidas de Telessaúde aplicadas à Teleodontologia, em nível nacional e no exterior. A RNTO é conduzida pela Associação Brasileira de Ensino Odontológico $(A B E N O)^{\perp}$ e pelo Núcleo de Teleodontologia da Faculdade de Odontologia da USP, ${ }^{2}$ em parceria com os núcleos de Telessaúde da Universidade do Estado do Rio de Janeiro, ${ }^{3}$ da Universidade Federal do Rio Grande do $\mathrm{Sul}^{4}$ e com a Secretaria da Saúde de Mato Grosso do Sul. ${ }^{5}$ O projeto é patrocinado pelo Ministério da Saúde ${ }^{6}$ com a colaboração da Organização Pan-Americana de Saúde (OPAS).

Por meio do Núcleo de Teleodontologia, é possível prover teleassistência aos profissionais de odontologia que integram o Programa de Saúde da Família do SUS. Este projeto é uma articulação do Telessaúde Brasil e é parte integrante da política nacional de Educação na Saúde, do Ministério da Saúde, na sua vertente de fortalecimento da Atenção Básica por meio da capacitação e apoio às Equipes de Saúde da Família.

O Núcleo também disponibiliza material didático-clínico para consultas, teleconferências com a discussão de casos clínicos apresentados e cursos de atualização. Está em implantação o sistema de Segunda Opinião em Odontologia que implica em assessoria para resolução de casos mais complexos. Na pesquisa, procura-se adequar os recursos de

\footnotetext{
1 http://www.abeno.org.br

www.teleodonto.fo.usp.br

http://www.telessaude.uerj.br

http://www.ufrgs.br/telessauders

http://telessaude.saude.ms.gov.br

http://www.saude.gov.br
} 
informática e de comunicação para as peculiaridades da Odontologia quer na Teleducação quer na Teleassistência.

O ensino a distância aplicado à saúde (e-Health) e à educação integra os esforços do Ministério da Saúde para desenvolvimento dos recursos da saúde humana. Conforme destacado por Haddad e colaboradores (2013), as múltiplas estratégias para o e-Health incluem principalmente o Programa Telessaúde Brasil Redes, ${ }^{7}$ a Universidade Aberta do Sistema Único de Saúde (UNA-SUS) ${ }^{8}$ e a Rede Universitária de Telemedicina (RUTE). ${ }^{9}$ Essas iniciativas são possíveis, graças à utilização de recursos de TICs para a interligação de universidades, hospitais universitários e institutos de pesquisa. A Rede Nacional de Pesquisa (RNP) por meio da RUTE (que é um programa da RNP) é responsável por prover os recursos para essa interligação. ${ }^{\circ}$

Por meio da RUTE, a RNP conseguiu interligar 150 hospitais universitários e de ensino e 100 unidades de telemedicina e telessaúde localizadas em todos os 27 estados do Brasil. Destaca-se que a Telessaúde é mais abrangente que a Telemedicina, pois inclui também vigilância, acesso à literatura e ao conhecimento médico.

A área da saúde tem desenvolvido formas de atendimento às necessidades profissionais e da sociedade geral por aplicações inovadoras das TIC. Dentre estas, destacam-se a emissão de segundas opiniões

7 www.telessaudebrasil.org.br

8 http://www.unasus.gov.br

9 http://www.rute.rnp.br

10 A RNP foi criada em setembro de 1989 pelo então Ministério da Ciência e Tecnologia (MCT), visando o estabelecimento de uma infraestrutura nacional de rede Internet de âmbito acadêmico. Em paralelo à implantação de sua primeira rede, a RNP dedicou-se a tarefas diversas, tais como divulgar os serviços Internet à comunidade acadêmica por meio de seminários, montagem de repositórios temáticos e programas de capacitação, além de programas específicos como o programa RUTE.

Em 2005, a tecnologia do backbone da RNP, que passou a se chamar rede Ipê, foi atualizada com enlaces ópticos (comprimentos de onda) operando a múltiplos gigabits por segundo. Foi chamada de Nova RNP a iniciativa de melhorar a infraestrutura de redes em níveis nacional, metropolitano e local (redes de campus); atender, com aplicações e serviços inovadores, as demandas de comunidades específicas (telemedicina, biodiversidade, astronomia etc.); e promover a capacitação de recursos humanos em tecnologias da informação e comunicação. 
formativas, a construção de bibliotecas em acesso aberto e discussão de processo de trabalho entre outros.

Os trabalhadores das Redes de Atenção à Saúde do Sistema Único de Saúde (SUS) podem, por exemplo, esclarecer dúvidas sobre procedimentos clínicos e ações de saúde em tempo real, via chat ou videoconferências. Os principais objetivos são melhorar a qualidade e agilidade do atendimento na Atenção Básica SUS, promover educação permanente dos profissionais de saúde e reduzir custos e tempo de deslocamento.

Uma das metas do NTO-FOUSP é o apoio ao trabalho em equipe multiprofissional de saúde, através da capacitação de profissionais para a teleconsultoria e da elaboração e catalogação das segundas opiniões formativas. Estas são uma derivação das teleconsultorias. "Entre muitas perguntas feitas pelos profissionais por meio das teleconsultorias, algumas são selecionadas pela sua relevância e pertinência. São questões que podem ser respondidas de forma genérica para atender a dúvidas de muitos profissionais. Elas são respondidas de forma sistematizada e padronizada”, explicam os professores. Entre os vários projetos desenvolvidos pelo núcleo, seus coordenadores destacam o da ABENO, que conta com o apoio do Ministério da Saúde e da OPAS e cujo objetivo é fomentar a criação de Núcleos de Teleodontologia vinculados a faculdades de odontologia em todo o país. A intenção é ampliar e fortalecer a Rede Nacional de Teleodontologia.

Essa pesquisa poderá integrar um estudo mais amplo, multidisciplinar e interinstitucional, cujo objetivo é investigar o significado da digitalização dos projetos de extensão da USP a partir da análise das transformações nas suas relações com a sociedade proporcionadas pelas arquiteturas informativas digitais e pelas suas possibilidades de disseminação, diálogo e colaboração em rede.

O desenvolvimento de pesquisas prevendo a incorporação de artefatos digitais interativos a Sistemas de Informação permitirá o estabelecimento de novas diretrizes para a construção de sistemas ubíquos, ou seja, sistemas que possam integrar artefatos digitais interativos à sua estrutura. 


\section{REFERÊNCIA}

BRAA, J.; HANSETH,O.; HEYWOOD, A.; MOHAMMED, W; SHAW, V. Developing Health Information Systems in Developing Countries: The Flexible Standards Strategy, MIS Quarterly, v. 31, n. 2, p. 381-402, 2007.

BROOKS JR, F. P. No Silver Bullet: Essence and Accidents of Software Engineering, IEEE Computer, v. 20, n. 4, p. 10-19, Apr. 1987.

CIBORRA, C,; BRAA, K.; CORDELLA, A. From control to drift: the dynamics of global information infrastructures. Oxford: Oxford University Press, 2000.

DI FELICE, M. Redes Sociais Digitais, Epistemologicas Reticulares e a Crise do Antropomorfismo social, Revista USP, São Paulo, n. 92, p. 6-19, dez./fev. 2011-2012.

EKBIA, H. R. Digital Artifacts as Quasi-Objects: Qualification, Mediation, and Materiality, Journal of the American Society for Information Science and Technology, v. 60, n. 12, p. 2554-2566, 2009.

GARUD, R.; JAIN, S.; TUERTSCHER, P. Incomplete by Design and Designing for Incompleteness, Organization Studies, v. 29, n. 3, p. 351-371, 2008.

HADDAD, A. et al. Experiência da Rede Brasileira de Teleodontologia, Jornal Brasileiro de Telessaúde, v. 2, n. 2, p. 81-83, 2013.

HANSETH, O. Understanding information infrastructure. Manuscript. 1998. Disponível em: <http://www.ifi.uio.no/ oleha/Publications/bok. html>. Acesso em: 03 nov. 2013.

HENFRIDSSON, O.; BYGSTAD, B. The Generative Mechanisms of Digital Infrastructure Evolution, MIS Quarterly, v. 37, n. 3, p. 907-931. Sept. 2013 .

HEVNER, A. R., S. T. et al. Design Science in Information Systems Research, MIS Quarterly, v. 28, n. 1, p. 75-105. 2004.

KALLINIKOS, J.; AALTONEN, A.; MARTON, A. The Ambivalent Ontology of Digital Artifacts, MIS Quarterly, v. 37, n. 2, p. 357-370. June 2013 .

KALLINIKOS, J.; AALTONEN, A.; MARTON, A. A Theory of Digital Objects, First Monday, v. 15, n. 6, 2010. Disponível em: <http:// 
firstmonday.org/ojs/index.php/fm/article/view/3033/2564>. Acesso em: 25 nov. 2013.

KALLINIKOS, J.; MARIATEGUI, J.-C. Video as Digital Object:

Production and Distribution of Video Content in the Intenet Media Ecosystem, The Information Society, v. 27, n. 5, p. 281-294, 2011.

LANZARA, G. F. Building digital institutions: ICT and the rise of assemblages in government. In: CONTINI, F.; LANZARA, G. F. ICT and innovation in the public sector: european studies in the making of e-government. London: Macmillan, 2009.

PRENSKY, M. Digital Natives, Digital Immigrants. 2001. Disponível em: <http://www.marcprensky.com/writing/Prensky\%2o-\%2oDigital\%2o Natives,\%20Digital\%20Immigrants\%20-\%20Part1.pdf>. Acesso em: | 21 nov. 2013.

RITTEL, H. J; WEBER, M., M. Planning Problems Are Wicked Problems. In: CROSS, N. (Ed.). Developments in Design Methodology. New York: John Wiley \& Sons, 1984.

VODANOVICH, S.; SUNDARAM, D.; MYERS, M. Digital Natives and Ubiquitous Information Systems - Research Comentar, Information Systems Research, v. 21, n. 4, p. 711-723, Dec. 2010.

YOO,Y; GOTHENBURG, S. Computing in everyday life: A call for research on experiential computing, MIS Quarterly, v. 34, n. 2, p. 213231, 2010.

YOO, Y.; HENFRIDSSON, O.; LYYTINEN, K. Research Commentary - The New Organizing Logic of Digital Innovation: An Agenda for Information Systems Research, Information Systems Research, v. 21, n. 4, p. 724-735, dec. 2010.

WATSON-MANHEIM, M.B.; BÉLANGER, F. Communication Media Repertoire: Dealing with the Multiplicity of Media Choice. MIS Quarterly, v. 31, n. 2, p. 267-293, 2007.

WEBER, R. Ontological Foundations of Information Systems. Brisbane, Australia: Coopers \& Lybrand, 1997.

ZAMMUTO, R. F. et al. Information Technology and the Changing Fabric of Organization, Organization Science, v. 18, n. 5, p. 749-762, 2007. 


\section{TRANSPARÊNCIA GOVERNAMENTAL ELETRÔNICA PARA ACCOUNTABILITY}

MARIA ALEXANDRA CUNHA, MARCO ANTÔNIO CARVALHO TEIXEIRA, TAIANE RITTA COELHO, MARIA CAMILA FLORÊNCIO DA SILVA, STEFANIA LAPOLLA CANTONI

INTRODUÇÃO

A Tecnologia da Informação e Comunicação (TIC) tem sido apontada como potencializadora da transparência e accountabilty tanto pela literatura internacional como pela produção nacional. Neste texto, utilizamos a literatura e casos práticos para argumentar que o uso das TIC para transparência faz sentido quando leva à melhoria da accountability. Para construir a nossa argumentação, partimos da definição de "transparência" e "accountability" e investigamos como, nos textos de transparência, a accountability é referenciada e vice-versa, como aqueles que escrevem sobre accountability fazem uso do termo "transparência”. É certo que há um razoável entendimento de que os processos de transparência governamental podem ser melhorados com a utilização da TIC, mas não há consenso sobre isso. Na segunda parte do capítulo, as visões otimista e pessimista sobre a transparência refletem-se também no uso de tecnologia. Descrevemos as diferentes dimensões utilizadas para avaliar transparência em sites governamentais. Finalmente, a partir de casos práticos, problematizamos transparência e accountability e sugerimos 
que o uso das TIC para a transparência é importante quando conduz a melhoria dos mecanismos de accountability.

\section{TRANSPARÊNCIA E ACCOUNTABILITY}

A transparência e o direito de acesso à informação governamental são internacionalmente considerados como essenciais para várias funções da democracia, como participação e accountability. (BERTOT; JAEGER; GRIMES, 2012) De acordo com as Nações Unidas, os conceitos de integridade, transparência e accountability são reconhecidos pela maioria dos países membros como fundamentos essenciais no setor público. (ARMSTRONG, E., 2005)

Vários acadêmicos examinaram maneiras de como a internet mudou a comunicação entre governos e seus constituintes locais. (ARMSTRONG, C., 2011; BERTOT; JAEGER; GRIMES, 2012; GRIMMELIKHUIJSEN, 2009) Estes autores têm sugerido que quanto mais informações os governos disponibilizam, a confiança e a eficiência do governo tendem a ser mais positivas. A transparência governamental é importante (ARMSTRONG, C., 2011; BERTOT; JAEGER; GRIMES, 2012; MEIJER, 2003), mas não é de fácil abordagem, devido ao "nevoeiro" que envolve o conceito. Para Liem (2007), existe uma falta de definição do termo transparência, de um conceito comum, o que leva por vezes a análises realizadas em um nível bastante abstrato. A transparência é vista por vários autores como conceito amplo e de difícil descrição. (GRIMMELIKHUIJSEN, 2009; LOURENÇO et al., 2013; MICHENER; BERSCH, 2013; RELLY; SABHARWAL, 2009)

O Quadro 1 resume diversos conceitos de transparência encontrados na literatura. Pode-se tratar transparência como uma relação horizontal entre o governo e o cidadão, permitindo o que é melhor para todos. (GRIMMELIKHUIJSEN, 2009) Alguns autores associam transparência ao acesso ou à disponibilidade de informação. (ARMSTRONG, C., 2011; CERRILLO-I-MARTÍNEZ, 2011; CRUZ; ÁLVARO, 2012; DEL SOL, 
2013; GRIMMELIKHUIJSEN, 2012; GRIMMELIKHUIJSEN et al., 2013; HALACHMI; GREILING, 2013; MEIJER; BANNISTER; GRIMMELIKHUIJSEN, 2011; PARAJULI, 2007; RIBEIRO; MATHEUS; VAZ, 2011; WELCH, 2012) Associam-na também à abertura das informações governamentais ao público externo ou à disponibilidade gratuita da informação.

Há outros autores que percebem transparência quando ocorre a possibilidade de controle ou monitoramento das ações públicas por parte dos cidadãos. (DAWES, 2010; GRIMMELIKHUIJSEN et al., 2013; GRIMMELIKHUIJSEN; WELCH, 2012; HALACHMI; GREILING, 2013; JACQUES; QUINTANA; MACAGNAN, 2013; MEIJER; BANNISTER; GRIMMELIKHUIJSEN, 2011) Assim, a transparência acontece à medida em que uma entidade revela informações relevantes sobre o seu próprio processo decisório, procedimentos, funcionamento e desempenho, capazes de subsidiar o processo decisório do cidadão. (GRIMMELIKHUIJSEN et al., 2013; JACQUES; QUINTANA; MACAGNAN, 2013)

Quadro 1 - Conceitos encontrados na literatura - Transparência

\begin{tabular}{|c|c|c|}
\hline ATRIBUTO & CONCEITO & REFERÊNCIAS \\
\hline \multirow{4}{*}{$\begin{array}{l}\text { Como um } \\
\text { conceito Amplo }\end{array}$} & $\begin{array}{l}\text { "transparência" oferece um conceito } \\
\text { de "bem ambivalente", com uma } \\
\text { carga normativa positiva. }\end{array}$ & $\begin{array}{l}\text { Michener e Bersch } \\
(2013)\end{array}$ \\
\hline & $\begin{array}{l}\text { Transparência é visto por políticos } \\
\text { e alguns estudiosos como uma } \\
\text { panaceia para permitir "boa } \\
\text { governação". }\end{array}$ & $\begin{array}{l}\text { Grimmelikhuijsen } \\
\text { (2009) }\end{array}$ \\
\hline & $\begin{array}{l}\text { A transparência é um conceito amplo } \\
{[\ldots . .] \text { "A transparência é a condução dos }} \\
\text { assuntos públicos ao ar livre ou está } \\
\text { sujeito a escrutínio público.". }\end{array}$ & $\begin{array}{l}\text { Relly e Sabharwal } \\
(2009)\end{array}$ \\
\hline & $\begin{array}{l}\text { Transparência é um termo complexo, } \\
\text { que pode ser analisado por meio de } \\
\text { um conjunto de dicotomias, sendo } \\
\text { principal aquela que ocorre entre o } \\
\text { evento e o processo de transparência. }\end{array}$ & Lourenço et al. (2013) \\
\hline
\end{tabular}




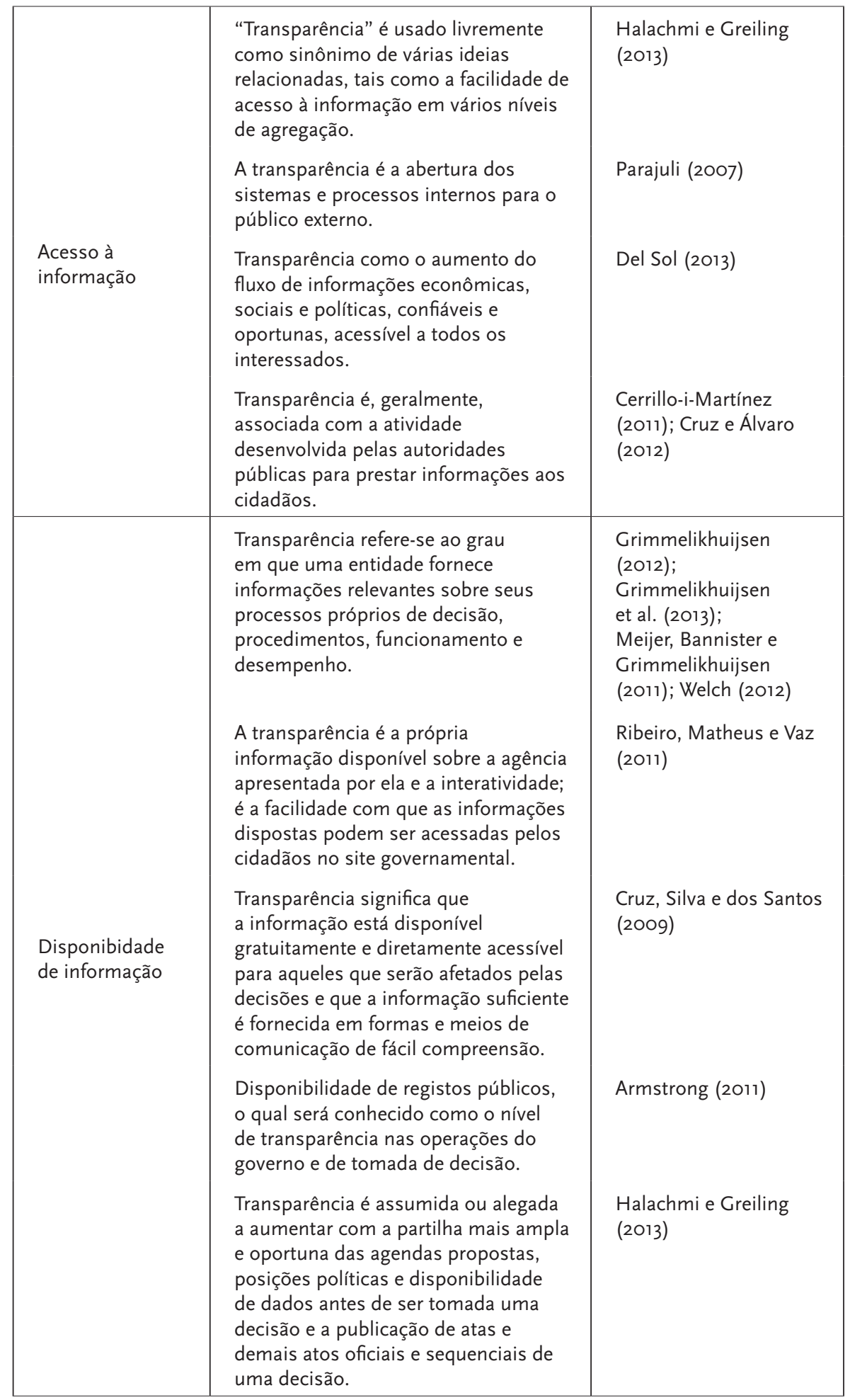




\begin{tabular}{|c|c|c|}
\hline & $\begin{array}{l}\text { Transparência pode ser direcionada } \\
\text { para fora (governo observando } \\
\text { cidadãos), para dentro (cidadãos } \\
\text { observando governo), para cima } \\
\text { (subordinados observando } \\
\text { seus supervisores) e para baixo } \\
\text { (supervisores observando } \\
\text { subordinados), ou qualquer } \\
\text { combinação desses. }\end{array}$ & $\begin{array}{l}\text { Meijer, Bannister e } \\
\text { Grimmelikhuijsen } \\
(2011)\end{array}$ \\
\hline & $\begin{array}{l}\text { Existe transparência quando os } \\
\text { cidadãos têm mais controle e formas } \\
\text { alternativas de acesso aos dados } \\
\text { brutos e influenciam o seu nível de } \\
\text { agregação. }\end{array}$ & $\begin{array}{l}\text { Halachmi e Greiling } \\
(2013)\end{array}$ \\
\hline & $\begin{array}{l}\text { Transparência à luz das tendências } \\
\text { sociais mais amplas sobre a } \\
\text { legitimidade, confiança e abertura. } \\
\text { A transparência definida como a falta } \\
\text { de sigilo e uma abertura ao escrutínio } \\
\text { público - é tradicionalmente } \\
\text { considerada como um meio para } \\
\text { reduzir a incerteza e aumentar a } \\
\text { confiança do público. }\end{array}$ & Dawes (2010) \\
\hline \multirow[t]{3}{*}{$\begin{array}{l}\text { Disponibilidade } \\
\text { e controle pelo } \\
\text { cidadão }\end{array}$} & $\begin{array}{l}\text { Transparência é vista como um } \\
\text { instrumento de política de governo: } \\
\text { pelo fornecimento de informações, o } \\
\text { governo facilita a tomada de decisão } \\
\text { dos cidadãos. Em segundo lugar, } \\
\text { o termo transparência é dito como } \\
\text { sendo um valor democrático. }\end{array}$ & $\begin{array}{l}\text { Grimmelikhuijsen e } \\
\text { Welch (2012) }\end{array}$ \\
\hline & $\begin{array}{l}\text { A transparência, mesmo derivando } \\
\text { diretamente do princípio } \\
\text { constitucional da publicidade, num } \\
\text { conceito mais amplo, abrange } \\
\text { a evidenciação de informações } \\
\text { confiáveis, relevantes, oportunas e } \\
\text { compreensíveis, capazes de subsidiar } \\
\text { o processo de controle social pela } \\
\text { sociedade. Transparência requer mais } \\
\text { do que se apresentar publicamente } \\
\text { ou ser visto por um número cada vez } \\
\text { maior de pessoas. }\end{array}$ & $\begin{array}{l}\text { Jacques, Quintana e } \\
\text { Macagnan (2013) }\end{array}$ \\
\hline & $\begin{array}{l}\text { O processo de transparência ocorre } \\
\text { "quando as organizações promovem } \\
\text { a tomada de decisão visível, éaberto } \\
\text { para a sugestão do público, permite } \\
\text { que o público escolha o máximo de } \\
\text { serviços e trabalha em cooperação } \\
\text { com outras organizações para fins } \\
\text { públicos comuns. }\end{array}$ & Armstrong (2011) \\
\hline
\end{tabular}




\begin{tabular}{|c|c|c|}
\hline $\begin{array}{l}\text { Disponibilidade } \\
\text { e monitoramento }\end{array}$ & $\begin{array}{l}\text { Transparência é a disponibilidade de } \\
\text { informações sobre uma organização } \\
\text { ou ator que permite que agentes } \\
\text { externos monitorem o funcionamento } \\
\text { interno, a realização dessa } \\
\text { organização ou ator. }\end{array}$ & $\begin{array}{l}\text { Grimmelikhuijsen } \\
\text { (2012); } \\
\text { Grimmelikhuijsen } \\
\text { e Welch (2012); } \\
\text { Grimmelikhuijsen } \\
\text { et al. (2013); } \\
\text { Meijer, Bannister e } \\
\text { Grimmelikhuijsen } \\
\text { (2011); Welch (2012), } \\
\text { p18, p22 } \\
\text { Grimmelikhuijsen et } \\
\text { al. (2013); Bannister } \\
\text { e Grimmelikhuijsen } \\
\text { (2011) }\end{array}$ \\
\hline $\begin{array}{l}\text { Quanto à } \\
\text { indisponibilidade } \\
\text { de transparência }\end{array}$ & $\begin{array}{l}\text { Ocorre em casos excepcionais em que } \\
\text { se justifica por segredo de Estado ou } \\
\text { por segurança da própria sociedade. } \\
\text { Todavia, deve ser em caráter de } \\
\text { exceção e não como regra. Passado } \\
\text { o perigo, a sociedade deve tomar } \\
\text { conhecimento do que ocorreu. }\end{array}$ & Bobbio (2000) \\
\hline Accountability & $\begin{array}{l}\text { Os termos accountability e } \\
\text { transparência estão estreitamente } \\
\text { relacionados. A diminuição da } \\
\text { opacidade administrativa propicia } \\
\text { maior possibilidade de conhecimento } \\
\text { do cidadão sobre a res publica. } \\
\text { Transparência concentra-se em } \\
\text { accountability. Seja qual for o caso, a } \\
\text { transparência é sempre uma condição } \\
\text { necessária como o primeiro passo no } \\
\text { processo de prestação de contas. }\end{array}$ & $\begin{array}{l}\text { Del Sol (2013); } \\
\text { Grimmelikhuijsen } \\
\text { (2009); Halachmi } \\
\text { e Greiling (2013); } \\
\text { Meijer, Bannister e } \\
\text { Grimmelikhuijsen } \\
\text { (2011) }\end{array}$ \\
\hline
\end{tabular}

Também foram encontrados autores (por exemplo, ALVES; SOUZA, 2011; CRUZ; ÁLVARO, 2012; CRUZ; SILVA; SANTOS, 2009; FRANCO et al., 2014) que abordam em seus textos a transparência fiscal, ou seja, a "possibilidade do acompanhamento claro, transparente, da execução orçamentária e das finanças públicas” (CRUZ; ÁLVARO, 2012), muitas vezes se reportando à Lei de Responsabilidade Fiscal.

A partir do conjunto dos autores citados, delimita-se o conceito. Assim, neste capítulo, transparência refere-se ao grau de disponibilidade de informação sobre uma agência, que pode ser acessada por 
todos os cidadãos e que permita que estes possam controlar e monitorar o funcionamento desta agência.

Alguns autores associam transparência à accountability (por exemplo, BAIRRAL; SILVA, 2013; CHEN, 2012; DEL SOL, 2013; GRIMMELIKHUIJSEN, 2012; LOUREIRO; TEIXEIRA; PRADO, 2008; LOURENÇO et al., 2013; MARENGO; DIEHL, 2011; MEIJER, 2003; RAUPP; PINHO, 2011; RIBEIRO; MATHEUS; VAZ, 2011), sendo então accountability definida como a obrigação de os funcionários públicos informarem sobre o uso dos recursos públicos e responsabilização do governo ao público para atender aos objetivos de desempenho declarados. (ARMSTRONG, E., 2005; BEHN, 2001; BOVENS, 2007; WONG; WELCH, 2004 apud LOURENÇO et al., 2013) A “[...] responsabilidade democrática exige que os governos aumentem a transparência, divulgando mais informações para os cidadãos, promovendo o controle das despesas públicas e prevenção da corrupção e desperdício de recursos públicos". (PINHO, 2008, p. 478) No entanto, “[...] a transparência é uma condição necessária, mas não suficiente, para assegurar uma maior accountability". (DEL SOL, 2013; HALACHMI; GREILING, 2013)

Em 1990, Campos com o seu emblemático texto "Accountability: quando poderemos traduzi-la para o português?”, concluiu que a inexistência de palavra que traduza seu significado no dicionário português se dá pelo aspecto cultural da Administração Pública não ser accountable. Quase 20 anos depois, Pinho e Sacramento (2009) escrevem o texto "Accountability: já podemos traduzi-la para o português?" onde concluem que apesar dos avanços, ainda estamos muito longe de construir uma verdadeira cultura de accountability. De acordo com Medeiros, Crantschaninov e Silva (2013, p. 1344), o termo que ganhou força após a queda do regime militar “[...] circunda a literatura em companhia de expressões como controle social, participação e a própria democratização do Estado" e se mistura com conceitos e abordagens relacionadas a perspectivas e visões, nem sempre de uma forma correta. (ROCHA, 2011) Nem sempre, aliás, tais conceitos e abordagens ficam evidentes. 
Com o fim de investigar a relação entre transparência e accountability, mais especificamente se transparência é elemento fundante deste, foi realizado um levantamento e análise da literatura nacional sobre accountability nos periódicos brasileiros classificados pela Comissão de Aperfeiçoamento de Pessoal do Nível Superior (Capes) como A2, B1 e B2 em Administração. O que o levantamento evidenciou foi que dos 38 (trinta e oito artigos), 11 (onze) não conceituavam accountability. Dentre os demais 27 (vinte e sete), 13 (treze) pressupunham transparência como sendo parte de accountability, e os outros 14 (quatorze) se dividiam entre 9 (nove) que não pressupunham e 5 (cinco) em que não foi possível ter certeza justamente por utilizar expressões como “acesso à informação", sem se referir ao termo. Disso se extrai que apenas $1 / 3$ dos trabalhos pressupõem que transparência é um elemento de accountability. Nestes, "[...] a transparência trata da visibilidade dos atos praticados no setor público e evidencia o acesso às informações e sua compreensão". (FONTES FILHO, NAVES, 2014, p. 9) Neste sentido, poderia ser considerada como "[...] a mais importante categoria da accountability como instrumento para avaliar o desempenho organizacional. Um requisito-chave para todas as outras. A transparência visa a mostrar a atuação das organizações e dos agentes públicos" (ROCHA, 2013, p. 72), "[...] uma condição sine qua non para o funcionamento dos mecanismos de responsabilização, já que, de fato, esses mecanismos de controle e fiscalização são fortemente condicionados pela transparência e pela visibilidade das ações do poder público". (CENEVIVA, FARAH, 2012, p. 1000) Nos outros 2/3 dos trabalhos, a definição aparece vinculada à responsabilização ou prestação de contas e apenas 10 (dez) dos 38 (trinta e oito) definem o que é transparência. Isso não quer dizer, contudo, que o termo não se fizesse presente, pois, na maior parte deles, "transparência" é empregada como uma qualidade da administração ou sinônimo de acesso à informação.

Também investigou-se como accountability aparece nos textos de transparência. Como observado por Grimmelikhuijsen (2012), a transparência, que visa melhorar a accountability permite que terceiros acessem e controlem as ações do governo. A informação disponível, 
por sua vez, capacita os cidadãos e, portanto, torna o governo mais democrático e mais confiável. (GRIMMELIKHUIJSEN, 2012; MEIJER, 2009; PINHO; SACRAMENTO, 2004; RIBEIRO; MATHEUS; VAZ, 2011) De acordo com Raupp e Pinho (2011),

[...] a transparência governamental é uma condição sine qua non para o funcionamento dos mecanismos de responsabilização, já que, de fato, esses mecanismos de controle e fiscalização são extremamente condicionados pela transparência e pela visibilidade das ações do poder público.

Neste sentido, a responsabilidade democrática exige que os governos aumentem a transparência, divulgando mais informações para os cidadãos, para que eles possam controlar as ações dos agentes públicos. (LOURENÇO et al., 2013)

Apesar da relação entre os conceitos, transparência e accountability não são sinônimos. (RIBEIRO; MATHEUS; VAZ, 2011) Deve notar-se que a transparência é uma condição necessária, mas não suficiente, para assegurar uma maior responsabilização pública (HALACHMI; GREILING, 2013), sendo o primeiro passo no processo de accountability. (MEIJER, 2003)

\section{O PAPEL DA TECNOLOGIA PARA A TRANSPARÊNCIA}

As Tecnologias de Informação e Comunicação (TIC) oferecem novas maneiras de aumentar a transparência no governo. (HALACHMI; GREILING, 2013) As TIC permitem que governos armazenem e divulguem grandes quantidades de dados a um custo baixo (MEIJER, 2007, 2009), dando possibilidades aos cidadãos de inspecionar o que as agências estão fazendo quase em tempo real. Os websites são uma ferramenta importante para a transparência, permitindo que as organizações governamentais forneçam as informações pró-ativamente. (MEIJER, 2011) E as mídias sociais têm tido um efeito transformador sobre as maneiras pelas quais as pessoas interagem umas com as outras e com os governos, bem como nas maneiras pelas quais os governos podem promover a transparência. (BERTOT; JAEGER; GRIMES, 2012) 
A transparência mediada pelas TIC visa melhorar a prestação de contas públicas, permite que terceiros acessem e fiscalizem as ações do governo. A melhor informação, por sua vez, capacita os cidadãos e, portanto, leva a governos mais democráticos e mais confiáveis. (GRIMMELIKHUIJSEN, 2012; MEIJER, 2009) Desta forma, o acesso à informação pode diminuir a assimetria entre a sociedade e o governo. (ANGÉLICO; ANTONIO, TEIXEIRA, 2012)

Quanto aos efeitos que a transparência pode trazer para a administração pública, pode-se dizer que há, em maior número, uma visão otimista, mas há registros de uma outra, pessimista. Embora a maioria dos autores reconheça que há muitos efeitos positivos de transparência, alguns outros chamam a atenção para alguns aspectos negativos.

Os "otimistas" abordam que uma maior transparência, que resulta de uma melhor utilização das TIC pode aumentar a confiança dos cidadãos, pode servir para limitar ou prevenir muitas oportunidades de comportamento corrupto (BERTOT; JAEGER; GRIMES, 2012), é um componente importante para a boa governança e pode aumentar a eficiência dos recursos, é essencial para a participação democrática, para precisão das informações do governo, e o fornecimento de informações para os públicos, empresas e jornalistas, entre outras funções essenciais na sociedade. (CULLIER; PIOTROWSKI, 2009; HOLMSTRÖM, 1979; MULGAN, 2007; QUINN, 2003; REYLEA, 2009; SHULER; JAEGER; BERTOT, 2010) Niklas Luhmann (2000) já declarou que a transparência é um primeiro passo necessário para restaurar a confiança dos cidadãos no governo. Ela cria uma cultura de abertura e isso proporciona efeitos positivos de confiança. (MEIJER; BANNISTER; GRIMMELIKHUIJSEN, 2011) A transparência aumenta a exposição das operações do governo ao escrutínio dos vários componentes do sistema político (MOON, 2002; TOLBERT; MOSSBERGER, 2006), aumentando o risco de ser pego. (DEL SOL, 2013) Os decisores políticos e estudiosos veem a transparência como um facilitador da boa governança (HOOD, 2006) porque ela estimula um melhor desempenho e aumenta a eficiência na alocação dos recursos. (DEL SOL, 2013; MEIJER, 2009) A transparência tornase uma ferramenta necessária para monitorar e avaliar o desempenho 
dos representantes e servidores públicos. Além disso, é um componente importante da boa governação e da qualidade institucional. (ACEMOGLU; JOHNSON; ROBINSON, 2002; KAUFMAN; KRAAY, 2002; WILLIAMSON, 2000) A transparência e o direito de acesso à informação do governo são considerados essenciais para a participação democrática. (BERTOT; JAEGER; GRIMES, 2010) Isto significa que, por meio do melhor entendimento das operações do governo que vem de uma maior transparência, os cidadãos poderão ter poderes para ter uma maior capacidade de influenciar as prioridades e procedimentos operacionais do governo. (HALACHMI; GREILING, 2013)

Por outro lado, os "pessimistas" assumem uma postura mais crítica e dizem que a transparência pode ocasionar a redução na eficiência administrativa e retardar as operações do governo devido à reduzida capacidade operacional que resulta do consumo de recursos escassos, aumentando os custos. (AIKINS; KRANE, 2012; HALACHMI; GREILING, 2013; LIEM, 2007) Ela pode ainda, comprometer "prestação de contas", facilitando o jogo político e pode reduzir a legitimidade de um determinado governo. (BOVENS, 2007; HALACHMI; GREILING, 2013) Liem (2007) observa que "a maior objeção contra a transparência é que ela pode ocasionar a redução na eficiência administrativa." Por exemplo, a transparência pode fazer tornar algumas ações administrativas mais eficazes, porém os mesmos esforços podem aumentar o custo marginal das operações do governo, principalmente quando há implicações nos recursos que são consumidos para alcançar a transparência. (HALACHMI; GREILING, 2013) Desta forma, a disponibilidade de informações poderiam tornar os procedimentos mais burocráticos em vez de aproximá-los dos cidadãos. (LIEM, 2007) Para Bovens (2005, p. 195), “[...] não há uma relação absoluta proporcional entre transparência e legitimidade”. Ainda segundo o autor, o aumento da transparência pode comprometer a accountability. O excesso de informação ou de muitos detalhes pode ser usado deliberadamente para intimidar e cercear o escrutínio público e a revelação de escândalos ou de algo que pode sugerir sua possível existência, pode ter o objetivo de reduzir a legitimidade de um determinado governo ou um arranjo 
de governança. (HALACHMI; GREILING, 2013) A transparência pode levar à desmistificação do governo, convidando a desafios desnecessários e reduzindo as ações do governo. (GRIMMELIKHUIJSEN, 2012) Para Dror (1999), a transparência é semelhante ao que os gregos chamavam de um fármaco, um material que cura apenas se tomado na dose certa.

Quando o foco é a investigação do uso de tecnologia da informação, à transparência geralmente está associada a dimensão de acessibilidade. Assim, são avaliadas questões tais como a receptividade do site à participação dos usuários, com materiais de treinamento (THORNTON; THORNTON, 2013) e ferramentas de suporte (i.e., mapa do site, ferramenta interna de busca), a capacidade de oferecer ajuda para facilitar o acesso às informações, as características que permitem ao usuário confiar no serviço prestado e facilitam o acesso a portadores de necessidades especiais e a funcionalidade estética e praticidade da distribuição das informações. (ALVES; SOUSA, 2011; MARENGO; DIEHL, 2011) Lourenço e colaboradores (2013) também incluem a visibilidade (como cada item torna-se visível no site) e o formato (ou apresentação) da informação. No que diz respeito aos "conteúdos" a serem tornados transparentes, na literatura nacional, a prestação de contas se materializa na divulgação da execução orçamentária, da gestão dos ativos e das dívidas do ente federativo de que se trate (CRUZ; ÁLVARO, 2012), nas publicações relacionadas a licitações e contratos (JACQUES; QUINTANA; MACAGNAN, 2013), assim como na divulgação do plano plurianual, da lei de diretrizes orçamentária e a lei orçamentária anual. (JACQUES; QUINTANA; MACAGNAN, 2013; MARENGO; DIEHL, 2011) Não só a publicação é suficiente, pois as atualizações, assim como os intervalos temporais da informação, também contam. Nesse sentido, Thornton e Thornton (2013) olha para o total de anos de dados históricos disponíveis, e Raupp e Pinho (2011) utilizam indicadores sobre a divulgação no prazo, parcial ou fora do prazo do conjunto de relatórios legais, assim como das suas versões simplificadas. A Associação Contas Abertas também avalia o quesito "Série Histórica e Frequência de Atualização" ao realizarem o índice 
de transparência dos estados e capitais brasileiras. Contudo, a transparência emerge como mais do que a questão contábil e financeira, pois órgãos transparentes também deveriam divulgar informações institucionais e outras mais gerais, entre elas: legislação (RAUPP; PINHO, 2011), informação sobre os representantes (CRUZ; ÁLVARO, 2012; JACQUES; QUINTANA; MACAGNAN, 2013), sobre os órgãos - estrutura, composição, funcionamento -, assim como da remuneração dos servidores e representantes. (JACQUES; QUINTANA; MACAGNAN, 2013) Finalmente, há autores que inserem o elemento interativo - ou até participativo - ao avaliarem a transparência. Raupp e Pinho (2011) e Jacques, Quintana e Macagnan (2013) olham para a existência de canais de contato (desde os mais básicos, como telefone, até os mais formais, como ouvidoria, passando por alguns mais interativos, como chats) assim como do monitoramento das ações dos usuários. Também, a possibilidade de oferecimento à população de instrumentos de participação no orçamento e em outros planos municipais.

Em síntese, a natureza ampla do conceito de transparência é bem elucidada em trechos de Jacques, Quintana e Macagnan (2013) e Cruz e Álvaro (2012), ao afirmarem que se procura prover o cidadão de informações claras e objetivas em áreas consideradas de maior interesse e cujas condições têm impacto direto na vida dos cidadãos: política tributária, administração, licitações e compras, segurança pública, educação, cultura, esporte e lazer, habitação e urbanismo, saúde, saneamento básico, gestão ambiental, atividades econômicas (indústria, comércio, serviços e agricultura), trabalho e transportes. Finalmente, a transparência também parece estar ligada aos dados abertos, pois as informações disponíveis, isto é, documentos, textos e relatórios, deveriam ser passíveis de download (RAUPP; PINHO, 2011), embora os dados abertos exijam outras características para serem considerados "abertos".

A literatura internacional vai em igual direção à nacional no que diz respeito à caracterização e à avaliação da transparência. Há transparência da atividade governamental na publicação de agendas e atas de reuniões, assim como na publicação de informação financeiras, sobre funcionários, e sobre a comunidade. (ARMSTRONG, C., 2011) 
Ao abordar as dimensões e indicadores da transparência on-line, Frick (2008) contempla a natureza ampla do conceito ao propor cinco dimensões. "Informação" referir-se-ia ao fornecimento de informações detalhadas sobre as funções do governo e dos funcionários. "Participação" constituiria a segunda dimensão, sobre a interação com os cidadãos através de ferramentas on-line para consulta e participação. "Relatório", diz respeito ao fornecimento de detalhes sobre decisões e ações de organizações do setor público, ou seja, da própria atividade pública pelos indicadores de desempenho. “Openness”, procuraria permitir que os usuários comparassem o desempenho do servidor público contra parâmetros pré-estabelecidos (arquivos dos discursos presidenciais, indicadores comparativos, indicadores sobre o plano do governo e seus objetivos específicos ao longo do tempo) e a última, "Accountability", visa permitir que os usuários adotem algum mecanismo de controle de recompensa ou punição - sobre os servidores públicos, através de mecanismos publicados para entrar em contato com os responsáveis de sites, da possibilidade de reclamar ou comentar sobre o desempenho dos empregados do governo e a presença de links de contato ou informações com o Provedor de Justiça.

Por fim, faz-se necessário estabelecer o processo que ligar Transparência à Accountability. Se considerarmos a existência de informações de fácil acesso e compreensão por parte dos cidadãos, e que estes, de posse delas, podem avaliar determinada situação ou processo decisório. Presume-se, também, que depois de ter analisado tais informações, esses cidadãos possam cobrar justificativas para os atos das autoridades públicas (responsabilidade) e, caso não se satisfaçam, prestarem queixa às instituições formais de controle em relação a algo que tenham identificado como desvio do padrão de comportamento esperado por parte do agente público.

Desse modo, tão importante quanto tornar disponível a informação de fácil compreensão para os cidadãos (dar transparência) é disponibilizar para a sociedade acesso às instituições de controle (accountability) para que o ciclo entre ambos se complete e, de fato, promova avanços substantivos da democracia ao possibilitar aos governados cobrar responsabilidade de seus governantes. 


\section{REFERÊNCIAS}

ACEMOGLU, D.; JOHNSON, S.; ROBINSON, J. A. Reversal of fortune: geography and institutions in the making of the modern world income distribution. Quarterly journal of Economics, v. 118, n. 4, p. 1231-1294, Nov. 2002.

AIKINS, S. K.; KRANE, D. Are public officials obstacles to citizencentered e- government? An examination of municipal administrators' motivations and actions. State and Local Government Review, v. 42, n. 2, p. 87-103, Aug. 2012.

AKUTSU, L.; PINHO, J. A. G. de. Sociedade da informação, accountability e democracia delegativa: investigação em portais de governo no Brasil. Revista de Administração Pública, Rio de Janeiro, ano 36, n. 5, p. 723-745, set./out. 2000.

ALVES, T. R.; SOUZA, C. A. Compras eletrônicas governamentais: uma avaliação dos sites de e-procurement dos governos estaduais brasileiros. Revista Eletrônica de Sistemas de Informação, Curitiba, v. 10, n. 1, jan./ jun. 2011.

ANGÉLICO, F.; ANTONIO, M.; TEIXEIRA, C. Acesso à informação e ação comunicativa: novo trunfo para a gestão social. Desenvolvimento em Questão, Ijuí, v. 10, n. 21, p. 7-27, 2012.

ARMSTRONG, C. L. Providing a clearer view: An examination of transparency on local government websites. Government Information Quarterly, v. 28, n. 1, p. 11-16, Jan. 2011.

ARMSTRONG, E. Integrity, transparency and accountability in public administration: recent trends, regional and international developments and emerging issues. New York: United Nations, 2005.

BAIRRAL, M. A. da C.; SILVA, A. Transparência no setor público: uma análise do nível de transparência dos relatórios de gestão dos entes públicos federais no exercício de 2010. In: ENCONTRO DA ASSOCIAÇÃO NACIONAL DE PÓS-GRADUAÇÃO E PESQUISA EM ADMINISTRAÇÃO, Rio de Janeiro, 2013. Anais... Rio de Janeiro, 2013. p. 1-16.

BEHN, R. D. Rethinking democratic accountability. Washington, DC: Brookings Institution Press, 2001. 
BERTOT, J. C.; JAEGER, P. T.; GRIMES, J. M. Promoting transparency and accountability through ICTs, social media, and collaborative e-government. Transforming Government: People, Process and Policy, v. 6, n. 1, p. 78-91, 2012.

BERTOT, J. C.; JAEGER, P. T.; GRIMES, J. M. Using ICTs to create a culture of transparency: E-government and social media as openness and anti-corruption tools for societies. Government Information Quarterly, v. 27, n. 3, p. 264-271, July, 2010.

BOBBIO, N. O futuro da democracia. Rio de Janeiro: Paz e Terra, 2000.

BOVENS, M. A. P. Analysing and Assessing Accountability: A Conceptual Framework. European Law Journal, v. 13, n. 4, p. 447-468, July, 2007.

CAMPOS, A. M. Accountability: quando poderemos traduzi-la para o português? Revista de Administração Pública, Rio de Janeiro, v. 24, n. 2, p. 30-50, fev./abr. 1990.

CENEVIVA, R.; FARAH, M. R. S. Avaliação, informação e responsabilização no setor público. Revista de Administração Pública, Rio de Janeiro, v. 46, n. 4, p. 993-1016, jul./ago. 2012.

CERRILLO-I-MARTÍNEZ, A. The regulation of diffusion of public sector information via electronic means: Lessons from the Spanish regulation. Government Information Quarterly, v. 28, n. 2, p. 188-199, Apr. 2011.

CHEN, Y.-C. A comparative study of e-government XBRL implementations: The potential of improving information transparency and efficiency. Government Information Quarterly, v. 29, n. 4, p. 553-563, Oct. 2012.

CRUZ, C. F. et al. Transparência da gestão pública municipal: um estudo a partir dos portais eletrônicos dos maiores municípios brasileiros. Revista de Administração Pública, Rio de Janeiro, v. 46, n. 1, p. 153-176, jan./fev. 2012.

CRUZ, C. F.; SILVA, L. M.; SANTOS, R. Transparência da gestão fiscal: um estudo a partir dos portais eletrônicos dos maiores municípios do Estado do Rio de Janeiro. Contabilidade, Gestão e Governança, Rio de Janeiro, v. 12, n. 3, p. 102-115, 2009. 
CULLIER, D.; PIOTROWSKI, S. J. Internet information-seeking and its relation to support for access to government records. Government Information Quarterly, v. 26, n. 3, p. 441-449, July, 2009.

DAWES, S. S. Stewardship and usefulness: Policy principles for information-based transparency. Government Information Quarterly, v. 27, n. 4 , p. 377-383, Oct. 2010.

DEL SOL, D. A. The institutional, economic and social determinants of local government transparency. Journal of Economic Policy Reform, v. 16, n. 1, p. 90-107, Jan. 2013.

DROR, Y. Transparency and openness of quality democracy. In: NISPACEE CIVIL SERVICE FORUM, 2., 1999. Maastricht, Netherlands.

Proceedings... Maastricht, Netherlands: EIPA, 1999. Disponível em: <http://www.nispa.org/files/publications/ebooks/nispaceeopennes2000.pdf\#page $=64>$. Acesso em: 10 nov. 2014 .

FLICK, M. Political mediation of e-Transparency. International journal of Electronic Government Research, v. 4, n. 3, p. 81-102, 2008.

FONTES FILHO, J. R.; NAVES, G. G. A contribuição do Sistema Integrado de Administração Financeira do Governo Federal (SIAFI) para a promoção da accountability horizontal: a percepção dos usuários. Brazilian Business Review, v. 11, n. 3, p. 1-28, maio/jun. 2014.

FRANCO, L. M. G et al. Nível de divulgação eletrônica da contabilidade pública dos municípios do Paraná no ambiente da internet. Revista de Ciências da Administração, v. 16, n. 38, p. 140-153, abr. 2014.

GRIMMELIKHUIJSEN, S. G. A good man but a bad wizard. About the limits and future of transparency of democratic governments. Information Polity, v. 17, p. 293-302, July, 2012.

GRIMMELIKHUIJSEN, S. G. Do transparent government agencies strengthen trust? Information Polity, v. 14, n. 3, p. 173-186, Aug. 2009.

GRIMMELIKHUIJSEN, S. G.; WELCH, E. W. Developing and Testing a Th eoretical Framework for Computer-Mediated Transparency of Local Governments. Public Administration Review, v. 72, n. 4, p. 562-571, Jul./ Aug. 2012. 
GRIMMELIKHUIJSEN, S. et al. The Effect of Transparency on Trust in Government: A Cross-National Comparative Experiment. Public Administration Review, v. 73, n. 4, p. 575-586, Jul./Aug. 2013.

HALACHMI, A.; GREILING, D. Transparency, E-Government, and Accountability. Public Performance \& Management Review, v. 36, n. 4, p. 572-584, Dec. 2013.

HOLMSTRÖM, B. Moral hazard and observability. The Bell Journal of Economics, v. 10, n. 1, p. 74-91, Spring, 1979.

HOOD, C. Transparency in a historical perspective. In: C. HOOD; D. HEALD (Ed.). Transparency: The key to better governance. Oxford: Oxford University Press, 2006. p. 3-23.

JACQUES, F. V. S; QUINTANA, A. C.; MACAGNAN, C. B.

Transparência em municípios da Região Sul do Brasil. In: ENCONTRO DA ASSOCIAÇÃO NACIONAL DE PÓS-GRADUAÇÃO E PESQUISA EM ADMINISTRAÇÃO, Rio de Janeiro, 2013. Anais... Rio de Janeiro, 2013. p. 1-13.

KAUFMANN, D.; KRAAY, A. Growth without governance. 2002. (World Bank Policy Research Working, 2928)

LIEM, S. I. Constituents of transparency in public administration with reference to empirical findings from Estonia. $320 \mathrm{f} .2007$. Dissertation (Doctor of Economics) - University of St. Gallen, St. Gallen, 2007. Disponível em: <http://verdi.unisg.ch/www/edis.nsf/ wwwDisplayIdentifier/3350/\$FILE/dis3350.pdf>. Acesso em: 10 nov. 2014 .

LOUREIRO, M. R.; TEIXEIRA, M. A. C; PRADO. Construção de instituições democráticas no Brasil contemporâneo: transparência das contas públicas. Organização Q Sociedade, Salvador, v. 15, n. 47, p. 107119, out./dez. 2008.

LOURENÇO, R. P. et al. Online Transparency for Accountability: One Assessing Model and two Applications. The Electronic Journal of e-Government, v. 11, n. 2, p. 280-292, 2013.

LUHMANN, N. Familiarity, Confidence, Trust: Problems and Alternatives, In: GAMBETTA, D. (Ed.). Trust: Making and Breaking 
Cooperative Relations. Oxford: Department of Sociology, University of Oxford, 2000. Cap. 6, p. 94-107.

MARENGO, S. T.; DIEHL, C. A. A possibilidade do controle social mediante o acesso a informações em sites dos municípios gaúchos. Contabilidade, Gestão e Governança, Brasília, v. 14, n. 3, p. 120-133, set./ dez. 2011.

MEDEIROS, A. K.; CRANTSCHANINOV, T. I.; SILVA, F. C. Estudos sobre accountability no Brasil: meta-análise de periódicos brasileiros das áreas de administração , administração pública, ciência política e ciências sociais. Revista de Administração Pública, Rio de Janeiro, v. 47, n. 3, p. 745-775, maio/jun. 2013.

MEIJER, A. J. Understanding Computer-Mediated Transparency. International Review of Administrative Sciences, v. 75, n. 2, p. 255-269, 2009.

MEIJER, A. J. Publishing performance results on the Internet: Do stakeholders use the Internet to hold Dutch public service organizations to account? Government Information Quarterly, v. 24, n.1, p. 165-185, Jan. 2007.

MEIJER, A. J. Transparent government: parliamentary and legal accountability in an information age. Information Polity, v. 8, n. 1-2, p. $67-78,2003$.

MEIJER, A. J. Being transparent or spinning the message? An experiment into the effects of varying message content on trust in government. Information Polity, v. 16, p. 35-50, 2011.

MEIJER, A. J., BANNISTER, F., GRIMMELIKHUIJSEN, S. Being transparent or spinning the message? An experiment into the effects of varying message content on trust in government. Information Polity, v. 16, n. 1, p. 35-50, Jan. 2011.

MICHENER, G.; BERSCH, K. Identifying transparency. Information Polity, v. 18, p. 233-242, 2013.

MOON, M. J. The evolution of e-Government among municipalities: Rhetoric or reality. Public Administration Review, v. 62, n. 4, p. 424-433, July/Aug. 2002.

MULGAN, R. Truth in government and the politicization of public service advice. Public Administration, v. 85, n. 3, p. 569-586, Sept. 2007. 
PARAJULI, J. A Content Analysis of Selected Government Web Sites: a Case Study of Nepal. The Electronic Journal of e-Government, v. 5, n. 1, p. 87-94, 2007.

PINHO, J. A. G. Investigando portais de governo eletrônico de estados no Brasil: muita tecnologia, pouca democracia. Revista de Administração Pública, Rio de Janeiro, v. 42, n. 3, p. 471-493, maio/jun., 2008.

PINHO, J. A. G.; SACRAMENTO, A. R. S. Accountability: já podemos traduzi-la para o português? Revista de Administração Pública, Rio de Janeiro, v. 43, n. 6, p. 1343-1368, nov./dez., 2009.

QUINN, A. C. Keeping the citizenry informed: Early congressional printing and 21 st century information policy. Government Information Quarterly, v. 20, n. 3, p. 281-293, July, 2003.

RAUPP, F. M.; PINHO, J. A. G. de. Construindo a accountability em portais eletrônicos de câmaras municipais: um estudo de caso em Santa Catarina. Cadernos EBAPE, Rio de Janeiro, v. 9, n. 1, p. 117-139, mar. 2011.

RELLY, J. E.; SABHARWAL, M. Perceptions of transparency of government policymaking: A cross-national study. Government Information Quarterly, v. 26, n. 1, p. 148-157, Jan. 2009.

REYLEA, H. C. Federal freedom of information policy: Highlights of recent developments. Government Information Quarterly, v. 26, n. 2, p. 314-320, Apr. 2009.

RIBEIRO, M. M; MATHEUS, R; VAZ, J. C. New perspectives for electronic government: the adoption of open government data in brazil. In: INTERNATIONAL CONFERENCE ON INFORMATION SYSTEMS AND TECHNOLOGY MANAGEMENT, São Paulo, 2011. Anais... São Paulo, 2011.

ROCHA, A. C. A realização da accountability em pareceres prévios do Tribunal de Contas de Santa Catarina. Revista de Administração Pública, Rio de Janeiro, v. 47, n. 4, p. 901-926, jul./ago. 2013.

ROCHA, A. C. accountability na administração pública: modelos teóricos e abordagens. Contabilidade, Gestão e Governança, Brasília, v. 14 , n. 2, p. $82-97$, set. 2011.

SHULER, J. A.; JAEGER, P. T.; BERTOT, J. C. Implications of harmonizing e- government principles and the Federal Depository 
Library Program (FDLP). Government Information Quarterly, v. 27, n. 1, p. 9-16, Jan. 2010.

THORNTON, J. B.; THORNTON, E. Assessing state government financial transparency websites. Reference Services Review, v. 41, n. 2 , p. 366-387, 2013.

TOLBERT, C. J.; MOSSBERGER, K. The effects of e-government on trust and and confidence in government. Public Administration Review, v. 66, n. 3, p. 354-369, May/June, 2006.

WELCH, E. W. The relationship between transparent and participative government: A study of local governments in the United States. International Review of Administrative Sciences, v. 78, n. 1, p. 93-115, Mar. 2012.

WILLIAMSON, O. E. The new institutional economics: taking stock; looking ahead. Journal of Economic Literature, v. 38, p. 595-613, Sept. 2000. 


\section{MOVIMENTO PASSE LIVRE E AS MANIFESTAÇÕES DE 2013 a internet nas Jornadas de Junho}

MAÍRA OURÍVEIS DO ESPÍRITO SANTO, EDUARDO HENRIQUE DINIZ, MANUELLA MAIA RIBEIRO

\section{INTRODUÇÃO}

Em junho de 2013, as ruas da cidade de São Paulo foram tomadas por milhares de pessoas como há muito não se via no país. Essas pessoas foram chamadas pelos atos do Movimento Passe Livre (MPL), que tem como uma das suas causas a adoção da tarifa zero no transporte público do país. Os atos tinham como objetivo protestar contra o aumento das tarifas no transporte público no município de São Paulo, que iam passar de três reais para três reais e vinte centavos.

No contexto dessas manifestações, que ficaram conhecidas como Jornadas de Junho, o uso da internet foi marcante. O MPL construiu um ciberespaço de discussão, de informação, de contrainformação e de divulgação de materiais que mostravam outras versões dos fatos, muitas vezes divergentes daqueles veiculados na grande mídia. A postura do MPL, favorável às novas mídias para construção de sua luta, é comprovada pela sua própria carta de princípios. Nela afirma que o movimento "deve utilizar mídias alternativas para a divulgação de ações e fomentar a criação e expansão destes meios. Já o contato com a mídia corporativa deve ser cauteloso, entendendo que estes meios 
estão diretamente atrelados às oligarquias do transporte e do Poder Público." (MOVIMENTO PASSE LIVRE, 2013a)

Frente às diversas possibilidades que a internet proporciona, a rede se constitui como um espaço de articulação de grupos, organizações e instituições. Os movimentos sociais incorporaram a internet para divulgar suas causas, lutas e estabelecer um diálogo direto com a sociedade sem depender dos grandes veículos de comunicação. A desconfiança em relação à mídia tradicional é reforçada por Caldas (2011), que aponta um novo tipo de coronelismo através do controle da mídia - elemento essencial na manutenção do poder das elites. Ainda mais porque, no Brasil, as emissoras de rádio e TV são concessões do governo e tendem a favorecer empresários e políticos que caminham lado a lado com o governo.

Os primeiros movimentos sociais que se apropriaram, de forma bem-sucedida, do ciberespaço utilizaram apenas lista de e-mails para apoiar suas atividades políticas. Em 1989, estudantes chineses ocuparam a Praça Tiananmen em protesto contra o regime e conseguiram, em grande medida, difundir o que se passava no país para a imprensa de todo o mundo, de forma totalmente independente da imprensa oficial. (CONKLIN, 2003) Em meados da década de 1990, foi o Exército Zapatista de Liberação Nacional (EZLN), do México (HILSENBECK FILHO, 2004; MORAES, 2000) que conseguiu compartilhar, de forma rápida, informações com muitos interlocutores acerca de como se encontrava a situação no país, quais eram seus propósitos e como fariam para alcançar seus objetivos.

Já nos anos 2000, alguns movimentos ganharam projeção internacional por terem conseguido mobilizar um grande número de pessoas, todos com um ponto em comum: a utilização das mídias eletrônicas descentralizadas como instrumento para articulação e divulgação de informações e materiais, como fotos, vídeos e textos. Castells e colaboradores (2005) relatam como o uso dos telefones celulares teve importante papel na organização de movimentos sociais nas Filipinas em 2001, na Coreia do Sul em 2002 e na Espanha em 2004. Mais recentemente, a série de manifestações conhecidas como Primavera 
Árabe, o movimento Occupy Wall Street e movimento dos Indignados, na Espanha, são os exemplos mais emblemáticos que acabaram por influenciar diversos movimentos de contestação em vários países.

No cenário brasileiro, o Movimento dos Trabalhadores Sem Terra (MST) faz uso do ciberativismo para se articular em rede, permitindo que seus militantes interajam com indivíduos dos mais diversos lugares do mundo, o que, consequentemente, propaga suas ideias de forma rápida e abrangente. (MILHOMENS, 2009) Entretanto, a maior expressão já vista no país do uso de mídias digitais na organização de ativismo social foram as Jornadas de Junho em 2013.

Assim, o objetivo deste artigo é identificar o papel da internet e da construção e compartilhamento de informações nas Jornadas de Junho, focando nas ações do MPL para convocar e divulgar as manifestações contra o aumento da tarifa do transporte público no primeiro semestre de 2013. Para compreendermos esse cenário e o lugar que a internet teve nesse processo, foram utilizadas referências bibliográficas relacionadas ao tema e também foi realizada entrevista com um dos integrantes da Comissão de Comunicação do MPL.

\section{O MOVIMENTO PASSE LIVRE}

Para compreendermos as Jornadas de Junho é necessário contextualizar o MPL, detalhando como o movimento foi fundado, quais as suas bandeiras e como está organizado. A exploração da história do MPL é relevante para a compreensão das Jornadas e permite enxergar como as mobilizações foram sendo gradativamente construídas. Parte-se da premissa de que as manifestações de Junho em São Paulo no ano de 2013 não foram um fenômeno isolado e descontextualizado.

Discussões sobre a gratuidade no transporte público ${ }^{\mathrm{I}}$ foram impulsionadas por alguns eventos que conseguiram avanços neste sentido.

I A proposta geral do movimento é que o serviço público de transporte seja pago por impostos progressivos para que assim seja abolida a tarifa. O movimento também propõe que a tarifa zero seja operacionalizada pela criação de um Fundo Municipal de Transporte Coletivo, gerido com a participação popular e mantido por arrecadação de multas de trânsito, estacionamento Zona Azul, parte do Imposto sobre a Propriedade de Veículos Automotivos 
Dignos de menção foram a Revolta do Buzu, ocorrida em 2003 em Salvador e a Revolta da Catraca, em Florianópolis no ano de 2004. (MANOLO, 2009) Durante o V Fórum Social Mundial, organizado por movimentos sociais de muitos países em Janeiro de 2005 em Porto Alegre, foi escrita e aprovada a Carta de Princípios que deu origem ao MPL. Se inicialmente limitava-se a defender o passe livre estudantil, o movimento ampliou a sua bandeira para defender o passe livre irrestrito, propondo a gratuidade do transporte público para todos os seus usuários. Em sua Carta, o MPL se propunha autônomo, horizontal, apartidário e independente. E desde o início, também adotou as mídias alternativas como instrumento de articulação e luta política.

Figura 1 - Logotipo do MPL

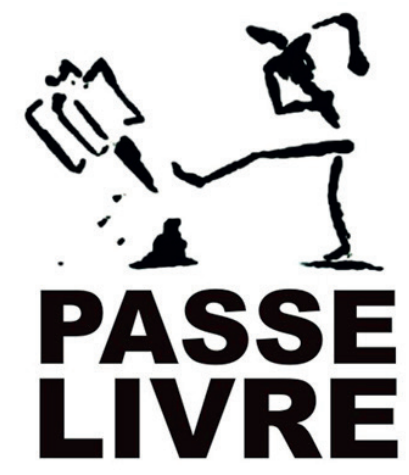

Com o lema "Por uma vida sem catracas", o MPL ressalta a catraca como um símbolo não apenas do transporte coletivo, mas também das desigualdades entre ricos e pobres, brancos e negros e homens e mulheres. O Movimento se compromete assim com o combate a "todas as catracas" que impeçam o acesso a espaços e serviços públicos.

(IPVA) e publicidade nos ônibus e terminais, nos metrôs e estações. (MOVIMENTO PASSE LIVRE, 2013b) O MPL também pretende estudar formas de tornar a participação popular efetiva, usando como modelo de sucesso os conselhos regionais de saúde existentes na cidade de São Paulo, formados por representantes da sociedade civil. 
Para o MPL, a gratuidade no transporte público é tratada como direito de todos já que

[...] $35 \%$ da população que vive nas cidades grandes não tem dinheiro para pagar ônibus regularmente. Inclusive, muitas pessoas estão excluídas de acesso a outros direitos e serviços públicos, como os relacionados à educação, porque não podem pagar o ônibus até a escola. (MOVIMENTO PASSE LIVRE, 2013b)

Para atingir seus objetivos, o MPL faz uso de diversas táticas, como ocupação de terminais de ônibus, fechamento de vias de circulação de automóveis, entrar pela porta traseira do ônibus ou descer pela da frente, passar por baixo da catraca do ônibus ou pular as catracas dos terminais ou estações (conhecido também como "catracaço"). (MOVIMENTO PASSE LIVRE, 2013c) No município de São Paulo, o Movimento contesta o sistema de transporte municipal desde 2006. Contudo, foi em 2013 que as manifestações encabeçadas pelo MPL contra o aumento da tarifa do transporte público em São Paulo tomaram grandes proporções e ganharam força para influenciar outros protestos pelo país inteiro.

\section{AS JORNADAS DE JUNHO}

As manifestações na capital paulista conhecidas como Jornadas de Junho foram desencadeadas pelo reajuste da tarifa do transporte público de três reais para três reais e vinte centavos no final de maio. Sete atos contra o aumento foram convocados pelo MPL na cidade de São Paulo, porém estima-se que 1,5 milhão de pessoas em mais de 120 cidades no Brasil saíram às ruas como resultado destas manifestações. (FERNANDES; ROSENO, 2013) Tal fervor das ruas não se verificava há pelo menos duas décadas: as últimas grandes manifestações no país haviam sido as do Fora Collor, em 1992, e antes disso as Diretas Já, entre 1983 e 1984. (SIMEONI, 2013)

Os protestos chamados pelo MPL naquele ano partiram inicialmente da organização de estudantes secundaristas, como os da Escola 
Estadual Ermano Marchetti, em Pirituba, bairro do noroeste da capital. Neste primeiro ato, aproximadamente 200 estudantes ocuparam o terminal de ônibus e a estação de trens da Companhia Paulista de Trens Metropolitanos (CPTM) de Pirituba, queimaram uma catraca e bloquearam ruas e avenidas de grande circulação da região. (MOVIMENTO PASSE LIVRE, 2013a) Outros atos regionais em outras escolas se seguiram e precederam os enormes protestos que levariam uma quantidade enorme de pessoas às ruas em torno de outras bandeiras que foram levantadas no decorrer das manifestações. Cabe destacar que o momento em que os grandes atos aconteceram em São Paulo e, posteriormente, no país todo, era um momento especial para o Brasil: em diversas cidades brasileiras, aconteceu, de 15 a 30 de junho, a Copa das Confederações FIFA 2013, com os olhos da mídia internacional voltados para o país.

O assim chamado " $1{ }^{\circ}$ Grande Ato" foi marcado para o dia 6 de junho e contou com a participação de cerca de 2 mil pessoas. Os manifestantes fecharam as Avenidas 9 de Julho, 23 de Maio e também a Avenida Paulista. A Polícia Militar, para dispersar os manifestantes, fez uso de bombas de gás lacrimogêneo e de efeito moral (FERNANDES; ROSENO, 2013), os manifestantes, por sua vez, tentaram dificultar a aproximação da polícia fazendo barricadas com cones, sacos de lixo e fogo. Também ônibus e prédios foram pichados. Ao final, 50 pessoas ficaram feridas e 15 foram presas. (PIRES, 2013) Tanto o governador do Estado, Geraldo Alckmin, quanto o prefeito Fernando Haddad alegavam, a esta altura, ser impossível atender à pauta do MPL. (FERNANDES; ROSENO, 2013)

Paralelamente, entretanto, o tema começa a ser divulgado também em sites ligados à questão da mobilidade urbana. Contrariando as declarações oficiais do poder público que dizia que o reajuste das passagens seguia abaixo do valor da inflação, foi divulgado que, pelo cálculo do IPCA² (IBGE) a tarifa do ônibus que era de R\$o,50 em 1994 deveria

2 De acordo com o Portal Brasil, a sigla IPCA significa Índice Nacional de Preços ao Consumidor Amplo e é o índice oficial do governo federal para metas inflacionárias, calculado pelo Instituto Brasileiro de Geografia e Estatística (IBGE). 
ser de R\$ 2,16 em 2013, e o metrô R\$ 2,59, considerando o índice de inflação de 332,22\% nesses 19 anos. Ou seja, o valor deveria, sim, estar abaixo dos R\$3,20. (EVOLUÇÃO..., 2013) A viabilidade da pauta do MPL também se mostrava realista pelo fato de já ter sido discutido na cidade o Projeto Tarifa Zero, de Lúcio Gregori, na época em que era secretário municipal de transportes da gestão da prefeita Luiza Erundina (1989-1992). (ALLEGRINI, 2013) Mesmo tendo sido arquivado, o projeto era um antecedente importante na cidade, dentro da própria Câmara de Vereadores, e mais pessoas deixavam de ver a pauta como utópica.

$\mathrm{O} 2^{\circ}$ Grande Ato contra o aumento das passagens de ônibus, metrô e trem foi então marcado para o dia seguinte, 7 de junho de 2013 . Dessa vez, cinco mil manifestantes aderiram ao evento e bloquearam a Marginal Pinheiros no sentido Castelo Branco, no horário de 19 h15 as 19h45. (PIRES, 2013) Para desmobilizar os participantes do protesto e fazer com que o trânsito fosse rapidamente liberado, a PM fez uso das bombas de gás lacrimogêneo, de efeito moral bem como spray de pimenta e balas de borracha. (FERNANDES; ROSENO, 2013)

Nesse momento, surgem os militantes Black Bloc que respondem à ação da polícia. De acordo com Judensnaider (2013), a origem dos Black Blocs remete ao movimento autonomista da Alemanha nos anos 1980, com manifestantes mascarados e vestidos de negro (der schwarze Block ou "o bloco negro") para dificultar a identificação da polícia. O "bloco negro" no seu modelo alemão se propunha a oferecer proteção às passeatas, limitando a infiltração de agentes provocadores e defendendo os manifestantes dos ataques da polícia.

Os Black Blocs reaparecem nos Estados Unidos, uma década mais tarde, nos protestos contra a Organização Mundial do Comércio (OMC) em Seattle, dessa vez orientados à destruição de propriedade privada como forma de protesto. Essa nova postura do grupo gera muita controvérsia entre os ativistas alinhados com a estratégia de não violência.

Embora a imagem do Black Bloc americano prevaleça no imaginário brasileiro (a começar pelo nome em inglês), na manifestação do dia 7, os Black Blocs assumem uma postura "clássica", articulando 
suas ações com a estratégia geral do MPL e se esforçando para proteger os manifestantes, ao invés de expô-los a mais violência.

Outro grupo, o Anonymous, também entra em cena ao invadir o site da Secretaria Municipal de Educação de São Paulo, deixando um chamado para o próximo ato. (JUDENSNAIDER, 2013) O Anonymous ficou internacionalmente conhecido em 2008 quando declarou guerra contra a cientologia. A partir de 2011 o grupo ganhou um caráter politizado, tendo tido forte participação no movimento Occupy, na Primavera Árabe e na luta pela liberdade na internet. Atuam hackeando sistemas de um alvo definido, em geral sites de bancos, governos, órgãos internacionais e de agências de controle de cartões de crédito. Além disso, hackeam bases de dados e disponibilizam para o público vídeos e dados pessoais de políticos. (GOHN, 2013) Por serem parte de um grupo internacional, assim como os Black Blocs, o Anonymous ajudou a mostrar as manifestações de Junho para o mundo.

Em 11 de junho, 12 mil pessoas aderiram ao $3^{\circ}$ ato, que teve início na Avenida Paulista, passou pelo centro e voltou para a mesma avenida, contabilizando, assim, seis horas de caminhada dos manifestantes. Na região da Praça da Sé, foram feitas pichações em prédios, e alguns chegaram a ser depredados, ônibus foram atacados na região do Parque D. Pedro II. (PIRES, 2013) A Polícia Militar, com a ordem de não permitir a entrada dos manifestantes no Parque, fez uso dos mesmos recursos usados nas manifestações anteriores. (FERNANDES; ROSENO, 2013)

Com um novo ato convocado para o final do dia 13 de junho, o jornal Folha de São Paulo publica um editorial com o título "Retomar a Paulista” em que classificava o MPL como um grupelho de bandeira irrealista. Neste editorial, propõe que "É hora de pôr um ponto final nisso. Prefeitura e Polícia Militar precisam fazer valer as restrições já existentes para protestos na Avenida Paulista, em cujas imediações estão sete grandes hospitais." (RETOMAR..., 2013, p. A2) O jornal O Estado de São Paulo também publica, na sessão Opinião, um artigo com o título "Hora do basta", condenando as manifestações. Tais posturas, aparentemente, "deram o sinal verde" para o aumento da intensidade da repressão policial que se seguiu naquela noite e que pode ser con- 
siderado divisor de água das Jornadas. $\mathrm{O} 4^{\circ}$ ato, de 13 de junho, com aproximadamente 10 mil pessoas na rua (COLETIVO DE REGISTRO DA LUTA CONTRA O AUMENTO, 2013) ganhou relevância dentro dessa série de manifestações pela intensidade da repressão policial. Antes mesmo de o protesto ter início, cerca de 40 pessoas foram presas na concentração. Conforme a manifestação foi recebendo mais participantes durante seu desenrolar e se encaminhando para parar o tráfego na Avenida Paulista, a Polícia Militar obtinha ordens de não permitir que os manifestantes chegassem ao seu destino. Sendo assim, 400 homens da polícia deram início à repressão de maneira indiscriminada, com o uso de gás lacrimogêneo, spray de pimenta e balas de borracha. A Tropa de Choque da Polícia Militar atirava mesmo sob gritos de não violência. "Pessoas que sequer participavam do protesto, mas estavam nos arredores, em lojas e bares, também sofriam agressões por parte dos policiais". (FERNANDES; ROSENO, 2013, p. 19) cento e trinta pessoas foram detidas, e cento e cinco ficaram feridas.

Um aspecto em especial da atuação da polícia fez com que a repressão fosse tão repudiada: muitos repórteres da grande mídia, mesmo que identificados com crachás, foram agredidos. O repórter Piero Locatelli, da revista Carta Capital, foi detido violentamente por "porte de vinagre", 3 pois esta substância é utilizada pelos manifestantes para amenizar os efeitos do gás lacrimogêneo. O fotógrafo do Portal Terra, Fernando Borges, também foi detido e ficou 40 minutos de frente para a parede, junto com outros manifestantes (MAGALHÃES; NOVAES, 2013) e a repórter Giuliana Vallone, da Folha de São Paulo, foi atingida por uma bala de borracha no olho. (PIRES, 2013)

A revolta em relação à atuação policial aumentou conforme fotos, relatos e vídeos postados nas redes sociais por pessoas que saíam do cenário de guerra em que se tornou a região da Rua da Consolação. A grande mídia, que no dia anterior deslegitimara os atos apontando os manifestantes como baderneiros e rebeldes sem causa, revisou suas impressões iniciais sobre os protestos e participantes. Não havia como

3 As manifestações ganharam o apelido de Revolta do Vinagre devido às diversas detenções de pessoas por porte de vinagre. 
questionar vídeos com policiais destruindo uma viatura da corporação para culpar manifestante, ou atirando com balas de borracha dentro de apartamentos de pessoas com câmeras, ou ainda utilizando fardas sem os nomes na lapela. As hashtags ${ }^{4}$ \#vemprarua e \#OGiganteAcordou começaram a se tornar cada dia mais comuns nas redes sociais, com o intuito de chamar mais pessoas a participarem das manifestações e saberem a realidade das ruas.

O volume de materiais compartilhados na internet fazia com que os usuários das redes sociais percebessem “[...] que estavam com dois enormes poderes nas mãos: produzir e distribuir informações”. (FERNANDES; ROSENO, 2013, p. 53) Isso lhes dava a consciência de que podiam fazer uso das redes sociais para informar o público em geral, de forma mais ampla e isenta, do que a mídia tradicional vinha até então fazendo.

É quando o grupo Mídia Ninja, ligado ao coletivo da área cultural Fora do Eixo, ganha destaque nas Jornadas de Junho. O grupo - Ninja significa Narrativas Independentes, Jornalismo e Ação - transmitia as manifestações pelo país em tempo real, com câmeras de celulares ligados ao site Pós-TV, recheando as imagens com debates e discussões. A proposta era apresentar uma forma diferente de televisão, permitindo a interação dos espectadores com os produtores do programa, principalmente via comentários no próprio site durante o acontecimento.

O Mídia Ninja, com uma narrativa alternativa àquela da mídia tradicional, mostrava que havia outro lado da história, buscando desconstruir o discurso de que a polícia somente havia tomado atitudes extremas por que havia sido atacada primeiro. Com isso, desmascarava a grande mídia que havia tentado desmobilizar os manifestantes e deslegitimar a causa. A rejeição às grandes redes de televisão se tornou tão evidente que os repórteres passaram a ter que retirar o logo da emisso-

4 Hashtags são as palavras precedidas pelo sinal \# que viram hiperlinks nas redes sociais, para apontar os assuntos dos quais se está falando. Ao adicionar o \# a alguma palavra e publicá-la, o usuário permite que quem esteja lendo e clicar nela veja todas as outras pessoas que também publicaram tal palavra desta mesma maneira. Este recurso, permite contabilizar a quantidade de menções feitas a determinado assunto, e assim avaliar a relevância de determinada discussão nas redes sociais. 
ra de seus microfones quando iriam fazer transmissões em meio aos manifestantes.

Os próprios meios de comunicação em massa começam então a mudar sua abordagem dos atos e passam a revelar a repressão policial. A Polícia Militar paulistana é rotineiramente truculenta e excessiva para os movimentos sociais na periferia, contudo esses abusos não causavam tanta comoção. Os alvos, desta vez, eram brancos de classe média e os repórteres e fotógrafos das grandes agências. (ALLEGRINI, 2013; SECCO, 2013)

No dia seguinte, as ações policiais foram duramente criticadas pela população, pelo governo e pela imprensa nacional e internacional. Os registros das agressões estampavam as capas de revistas e jornais mais importantes do Brasil e do mundo. [...] A posição dos veículos de comunicação mais conservadores se alterou, e duras críticas foram feitas às ações violentas e ao despreparo da polícia que reagiu contra os manifestantes. (FERNANDES; ROSENO, 2013, p. 19)

A partir daí, os atos ganhariam outra forma e outro sentido, já que as manifestações se disseminaram por todo o país Brasil. Com o aumento da lista de cidades organizando protestos, aumentava também a diversidade das reivindicações. (JUDENSNAIDER, 2013) A mídia que antes mencionava os atos apenas durante os noticiários de sua grade de programação, passou a cobri-los em tempo real, com repórteres ao vivo, direto dos locais das manifestações. A mobilização começa a ser relatada pela sua abrangência nacional, e não apenas como protestos isolados. Contudo, os meios de comunicação retratavam o movimento como composto por dois grupos: um com pessoas bem-intencionadas e outro com vândalos responsáveis pela degradação e má fama dos atos.

Ao longo do final de semana, entre o ato do dia 13 e o seguinte, marcado para o dia 17 , as postagens nas redes sociais ganharam uma nova característica interessante. Tanto em perfis de pessoas quanto de coletivos e organizações, apareciam orientações sobre como agir durante a manifestação, indicando, por exemplo, o uso de vinagre para 
aliviar os efeitos das bombas de gás lacrimogênio lançadas pela polícia e as saídas para evitar a revista da Polícia Militar em busca de vinagre.

Após o ato do dia 13, passaram a ser comuns postagens sobre como ajudar o movimento sem necessariamente ir às ruas, pois o medo havia tomado conta de muitos depois das violentas imagens da manifestação anterior. Algumas sugeriam desde abrir as redes wifi para facilitar a troca de informações ou colocar lençóis brancos nas janelas em apoio aos manifestantes, até lugares em que haveria postos de atendimento médico. (JUDENSNAIDER, 2013, p. 136) Uma rede de apoio foi sendo construída ainda que não necessariamente em torno da pauta dos $\mathrm{R} \$ 0,20$.

Numa clara indicação da mudança da orientação editorial, no dia 15 de junho o jornal $O$ Estado de São Paulo publica um artigo na seção Opinião intitulado "Entender as manifestações", com uma postura muito mais branda do que aquela do dia 13. A Folha de São Paulo reconhecia a violência da Polícia Militar no editorial publicado com o título "Agentes do caos":

A Polícia Militar do Estado de São Paulo protagonizou, na noite de anteontem, um espetáculo de despreparo, truculência e falta de controle ainda mais grave que o vandalismo e a violência dos manifestantes, que tinha por missão coibir. Cabe à PM impor a ordem, e não contribuir para a desordem. (ENTENDER..., 2013, p. A2)

Em 17 de junho, 65 mil pessoas (ATO..., 2013), participaram do $5^{\circ}$ Ato chamado pelo MPL. A concentração se deu no Largo da Batata e se dividiu em três frentes. Uma cruzou os Jardins até a Avenida Paulista. Outra passou pela Ponte Eusébio Matoso e pela Marginal Pinheiros, seguindo até a Ponte Octavio Frias de Oliveira (Ponte Estaiada), sobre o Rio Pinheiros. E a última passou pela Avenida Brigadeiro Faria Lima, pelo Itaim-Bibi e também se dirigiu à Ponte Estaiada. De lá se juntaram ao grupo que havia se dirigido à Av. Paulista, e uma parte se desviou para a Avenida 23 de maio. (PIRES, 2013) Ao passar pelas principais vias de fluxo de automóveis da capital paulista, a manifestação obteve demonstrações claras de apoio da população, com pessoas jogando pa- 
pel picado ou estendendo panos brancos nas janelas. Em contraste com a manifestação anterior, neste dia não houve repressão.

Na Avenida Faria Lima, apenas seis policiais acompanhavam o protesto. (BRITO; BREDA, 2013) Bombas de gás e balas de borracha não foram usadas. Durante a caminhada, gritos de "que coincidência, não tem polícia, não tem violência”, deixavam clara a percepção de que os confrontos tinham origem no uso abusivo da força policial.

Em contradição com as declarações dadas ainda durante as primeiras manifestações, em 19 de junho, o governador Alckmin e o prefeito Haddad anunciam a revogação do reajuste da passagem do transporte público em São Paulo, que voltou a custar R \$3,00. (JUDENSNAIDER, 2013) Indubitavelmente, uma vitória, e que precisava ser comemorada nas ruas.

Novo ato chamado pelo MPL para 20 de junho contou com cerca de 110 mil participantes. (EM DIA..., 2013) O MPL reconhecia que, apesar de ter alcançado o que era objetivo do momento, precisava continuar fiel a sua pauta de tarifa zero. A manifestação comemorativa indicaria, portanto, apenas que parte de um longo caminho havia sido trilhado para que essa luta fosse de fato vencida.

Em todo o país, mais de cem cidades conseguiram a revogação do aumento da tarifa de transporte público. O povo continuou e continua nas ruas por diversas outras pautas. Por outro lado, a descrição das manifestações ocorridas em junho de 2013 na cidade de São Paulo chamam a atenção para a necessidade de aprofundamento do olhar sobre o assunto. Até o momento, tem-se a narrativa dos acontecimentos, mas não exatamente a compreensão completa do cenário que propiciou o advento das Jornadas de Junho.

\section{AS JORNADAS DE JUNHO E A INTERNET}

A internet, como mencionado em trechos da descrição aqui feita, foi importante para fazer circular informação, construir versões alternativas dos fatos àquelas propostas pela mídia em geral. Por mais que muito se discuta sobre o papel da rede para os movimentos sociais, os fatos recentes no Brasil e no cenário mundial mostram que existe uma 
contribuição importante da internet para a comunicação alternativa e a articulação desses movimentos. A contraposição entre mídia tradicional e mídia alternativa ressalta essa oportunidade criada pela rede.

Mesmo para aqueles de menor poder econômico, a internet aparece como um meio alternativo de comunicação, pois hoje nas favelas brasileiras 50\% dos domicílios já possui acesso à rede. (PAPP, 2013) Apesar da televisão e o rádio constarem ainda como os principais meios de comunicação, a internet apresenta um grande potencial a ser explorado.

Acontecimentos recentes relatados neste capítulo evidenciam como a internet se constituiu num meio para divulgação de versões diferentes àquelas transmitidas pela grande mídia, tornando possível o acesso às informações que não estavam pautadas pela TV, rádio e jornais e revistas tradicionais. A divulgação de vídeos, áudios e imagens também permitiram a comprovação da veracidade das versões alternativas:

Curiosamente, foram as redes sociais que permitiram isso. Vejam o que aconteceu na Tunísia ou no Egito, onde ditaduras muito antigas, de mais de cinquenta anos, acreditavam que já dominavam a sociedade porque controlavam o rádio, a televisão e a imprensa escrita. Mas, de repente, as novas gerações começaram a conhecer o conteúdo do WikiLeaks, repassando a informação pelo Facebook, Twitter ou e-mail. Elas se autoinformaram, protestaram, criaram uma contraopinião pública, e as ditaduras não puderam resistir. Atualmente, os jovens do mundo - na Espanha, nos Estados Unidos, na Grécia, na Inglaterra, em Israel, no Chile - estão se autoinformando e protestando contra uma espécie de aliança entre os poderes tradicionais e o poder midiático. (RAMONET, 2013, p. 99)

Os movimentos sociais recebem, em geral, cobertura parcial e desfavorável da mídia. Neste aspecto, são oprimidos não apenas em suas manifestações de rua, mas também ao serem retratados de forma negativa pelos principais agentes de formação da opinião pública:

[...] os grupos dominantes, associados com militares e policiais, continuam a criminalizar amplos setores da sociedade civil, principalmente as manifestações mais firmes de traba- 
lhadores da cidade e do campo. Auxiliados por uma parte dos meios de comunicação de massa e da indústria cultural, insistem em desqualificar e reprimir as reivindicações populares. Classificam as mais óbvias manifestações da questão social como problemas de 'violência' urbana e rural. Afirmam cotidianamente que a violência é a do outro. (IANNI, 1989 apud CALDAS, 2011, p. 34)

O comportamento da mídia tradicional durante as Jornadas de Junho é revelador. Enquanto os jornais de grande circulação chamavam os manifestantes de vândalos, na internet circulavam vídeos de policiais depredando os próprios carros e atirando dentro de residências. Ao adotar uma via alternativa de comunicação com a sociedade, os movimentos sociais conseguem mostrar a sua versão dos fatos, independente do filtro da mídia, influenciando diretamente a opinião pública e, em alguns casos, como foi visto aqui, a própria mídia tradicional. Nesse contexto:

A utilização da Internet, de redes eletrônicas de comunicação e o volume de informações produzidas e transmitidas, são também responsáveis pelo escape à tradicional (e muitas vezes velada) censura dos meios de comunicação, favorecendo o elemento surpresa e a escolha do momento para sua ação política, como a data definida para o início do conflito, que conseguiu a atenção da mídia, repercussão e reconhecimento da guerrilha como ator político que não poderia mais tão facilmente ser silenciado pelo governo e os meios de comunicação oficiais. (HILSENBECK FILHO, 2004, p. 2)

Entretanto, se a tecnologia pode ser mais um instrumento na articulação das lutas sociais, ela não deveria ser encarada como o elemento principal que dá vida aos movimentos que levam as bandeiras dessas lutas. É preciso encontrar um meio termo entre a aversão à tecnologia e o seu endeusamento.

De qualquer forma, as novas tecnologias da internet precisam ser incorporadas pelos movimentos sociais. Como citado no início deste capítulo, elas ajudam a ampliar a capacidade desses movimentos, per- 
mitindo a troca de informação de forma descentralizada, o que faz com que qualquer pessoa possa ser um agente de divulgação, em oposição à estrutura rígida de veiculação de informações da mídia tradicional.

Os blogs possibilitaram que alguém com pouco conhecimento sobre os sistemas jornalísticos publicasse seus textos e imagens para qualquer pessoa que quisesse acessá-lo. Indo além, as redes sociais facilitaram a propagação de informações em tempo real, acelerando a circulação de conhecimento sobre algum fato ou fenômeno que, em geral, não atrairia um jornal estabelecido e nem teria tempo para ser encaminhado através de uma redação tradicional. A portabilidade dos dispositivos celulares potencializou ainda mais essa troca de informações, permitindo com que as pessoas divulguem o que desejam, em tempo real, do local do acontecimento.

\section{A INTERNET E O MOVIMENTO PASSE LIVRE}

Dados do Comitê Gestor da Internet no Brasil (2014) mostram que $85 \%$ da população brasileira usou o telefone celular nos últimos três meses. Destes, 31\% usou a internet no celular. Entre os que utilizaram internet no celular, $73 \%$ o fizeram diariamente, $20 \%$ uma vez por semana, $5 \%$ uma vez por mês e $2 \%$ menos de uma vez por mês. Esses fatores levam à vivência de uma nova experiência de tempo e espaço. (HARVEY, 2006) Todas essas tecnologias, em especial as redes sociais, fizeram com que as Jornadas ganhassem tamanha dimensão. Ao dar voz ao próprio MPL, é possível colher as impressões desta organização sobre o papel da internet no processo de construção e articulação das lutas sociais. Como relatou em entrevista ${ }^{5}$ um dos responsáveis pela comunicação do MPL:

[...] os próprios manifestantes noticiando, no Facebook, tirando foto, colocando vídeo no Youtube, noticiando pras pessoas, falando 'tirei a foto aqui, olha a bala de borracha que eu tomei', 'olha esse cara, como é que ele tá', 'tô aqui na delegacia há 'x' horas'

5 Entrevista realizada como parte da pesquisa empírica da dissertação de Espírito Santo (20I4), Lutas sociais e ciberespaço: o uso da internet pelo Movimento Passe Livre nas manifestações de junho de 2013 em São Paulo. 
Eles têm um papel muito importante na informação, quanto mais gente falando... A gente acha que grande parte do tamanho que toma é porque a maioria das pessoas se apropriaram disso e elas se tornam sujeitos também da luta, quanto mais gente lutando melhor. O MPL não é a única organização que tá nessa luta e nem quer ser. Gente que tá lutando pelo transporte e não tá no MPL, maravilha. Gente que tá na manifestação e tá fazendo a notícia, não precisa ser uma página oficial do Facebook, do MPL, do Passe Livre São Paulo pra ter uma relevância na importância da luta, é isso. Teve uma importância muito grande em desmistificar e deslegitimar uma versão que estava sendo mantida pela mídia [...]. (MILITANTE MPL, 2013)

Da maneira geral, o MPL tem claro que precisa se organizar para trabalhar a sua comunicação, elemento bastante relevante da própria ação que cabe aos movimentos sociais. A existência de uma Comissão de Comunicação estruturada dentro do movimento mostra a importância desse aspecto para o MPL:

A gente busca ser dono da própria luta, a nossa comunicação é feita por nós mesmos, a gente não vai esperar que a Globo faça a cobertura do nosso ato, isso nacionalmente, e a gente não vai esperar que a divulgação do nosso ato saia na Folha de São Paulo, então como que a gente faz, das mais diversas maneiras, das mais diversas táticas, a gente faz essa divulgação, e ai vale o quê? Vale internet? Vale. Vale evento no Facebook? Vale, mas a gente existia antes do Facebook existir. Vale comunidade no Orkut? Vale, mas tudo isso ai vem antes das coisas tomarem uma proporção muito grande no Brasil, então isso vem de antes, vai do boca-a-boca, de eventos, de discussões, de debates, vai de panfletagens, de colagem de lambes, de cartazes, tem as mais diversas maneiras para que a gente consiga, que a gente possa, porque a gente tem a questão financeira. O financeiro é muito forte, boa parte da nossa estética ela é em preto e branco hoje em dia porque a gente não tem dinheiro pra rodar panfleto colorido, a gente não tem tempo pra fazer mil atos, então a gente faz isso porque é o que dá. A gente busca ser dono da própria comunicação, a gente tem a nossa página nos meios, a gente tem o nosso site, é lá que a gente informa 
a nossa versão, porque não é confiável, a gente entende que tem uma disputa política e nessa disputa política tem gente que se utiliza dos mais diversos meios pra fortalecer seu lado, então é isso, a manifestação é sobre transporte, boa parte das pessoas que estão lá sabe que é pro transporte, tá lá pelo transporte, mas mesmo assim vai sair outra coisa no jornal. Mesmo assim vai sair outra versão. (MILITANTE MPL, 2013)

Dentro do universo de possibilidades da internet, o MPL enxerga a grande relevância da comunicação, mas é interessante perceber que também enxerga as limitações da rede na construção de suas lutas e reconhece as incontáveis potencialidades de ação da internet, mas não crê que ela venha a resolver todos os problemas:

O Facebook ele tem uma força muito grande em alguns aspectos, em outros aspectos o Youtube tem uma função muito importante pra sinalizar as agressões policiais. O CMI [Centro de Mídia Independente] tem essa função histórica de servir como agregador dessas mídias, dos blogs e tudo mais. Tumblr agora teve para mostrar as fotos. Eles têm essa importância sim, das pessoas mostrarem, terem acesso a essa possibilidade, mas assim duvido que... Se não tivesse Internet ainda ia ter Junho, se não tivesse o evento no Facebook para convidar os amigos, iriam mandar mensagens de celular pra eles, ou ia chegar no trabalho e falar pra eles, se não tivesse Tumblr pra mostrar as fotinhos, você ia chegar lá, arregaçar a calça da perna e mostrar a porra da bala de borracha, ou você ia chegar no trabalho e o cara ia ver sua cara, o jeito que ela tava. É isso, tem sua importância, mas tem seus limites e contextualizar isso, abre um caminho pra uma coisa muito complicada, como se não fosse uma questão das pessoas lutando, como se as mídias fossem os instrumentos mobilizatórios, não é isso, tá longe disso. (MILITANTE MPL, 2013)

Na fala do militante do MPL, aparecem várias redes e mostra que o MPL tem consciência da possibilidade de ação e divulgação de informações em diversas frentes e em diferentes formatos. Ao discorrer sobre outras formas de uso do ambiente virtual, o representante do MPL também demonstrou a existência de articulação com outros gru- 
pos que também buscam mudanças. Ratifica que vida real e virtual não somente se complementam, mas se sobrepõem e as lutas devem se dar em ambos os ambientes.

A gente tem tentado usar agora mais livestreaming com ajuda de outros coletivos de mídia alternativa, de mídia independente que tem esse debate já feito. CMI, Passa-Palavra, Ação Direta de Vídeo Popular, Mídia Negra são muitos coletivos que apoiam a gente nisso. (MILITANTE MPL, 2013)

Tal articulação fortifica a luta dos movimentos sociais e amplia suas discussões. Contudo, apenas a publicação na rede não pode limitar a ação nem de indivíduos nem dos movimentos. Se há possibilidade de responder às publicações feitas nos perfis do MPL nas redes sociais permite criar interação com outros indivíduos interessados na mesma luta, Luca alega que a atual composição do MPL não favorece a manutenção desta dinâmica.

Isso não significa que o MPL apenas faz divulgação na rede e não acompanha o que acontece depois. Luca explica que, embora o monitoramento da página do MPL no Facebook, por exemplo, seja superficial, se há muitos compartilhamentos, pode-se entender que as pessoas compreenderam o que fui publicado. Partindo da interpretação da resposta das pessoas, o MPL busca elementos para planejar como continuar construindo sua comunicação direta.

Essa preocupação do MPL em se fazer entender e em estabelecer um diálogo demonstra uma consciência de seu poder de conscientização, informação e até de educação. Ao demonstrar disposição em se fazer entender e não estar fechado em si mesmo, o MPL se considera de fato comprometido em levar sua luta a outros patamares de discussão e atuação. Talvez este tenha sido um dos fatores que ajudou na popularização do MPL na rede. Luca diz que, antes das Jornadas de Junho a página Passe Livre São Paulo no Facebook tinha 10 mil curtidas. Este número saltou para 295 mil durante as Jornadas. Contudo:

[...] no pico da luta contra o aumento, no final dela, dia 19, a gente tinha, aproximadamente, 8 a 10 milhões, teve um crescimento 
muito grande. [...] É um negócio que atinge uma proporção meio irreal também, não são 295 mil pessoas que são do Passe Livre, nem que adoram o Passe Livre, nem nada, são 295 mil pessoas que curtem a página, é isso. É tudo isso que significa. E isso aí tem todas as problemáticas, não são essas pessoas que acham importante fazer a discussão dos transportes, são pessoas que curtem a página, a gente tem noção disso, é muito importante ter essa noção. (MILITANTE MPL, 2013)

Novamente está presente a ponderação entre possibilidades e limites do uso da rede. Isto é de extrema relevância para não alardear o entusiasmo com a tecnologia sem refletir sobre seus limites e oportunidades para os movimentos sociais. Ao mesmo tempo, não se deve diminuir a importância que a internet pode vir a ter para os movimentos sociais. Fazer ouvir/ler as ruas na rede é uma luta política paralela contra a mídia tradicional. E uma luta com obstáculos muito maiores se for levado em conta o cenário de um país com a extensão e as características socioeconômicas como o Brasil. Há uma grande diversidade de mundos dentro do próprio território nacional. "Dialetos" regionais, parcas condições de infraestrutura, realidades muito opostas dentro de um mesmo ambiente. Quanto ao uso da internet nessa realidade, o MPL considera que:

[...] Você atinge só uma parte da população, talvez seja importante pra essa parte da população, seja uma boa estratégia para atingir essa parte da população. Porque agora tem um pouco mais de crescimento econômico de umas certas camadas, da popularização de acesso à Internet, então você diminui assim, mas é aquela velha história, aquele velho mito... um dia fizeram uma pesquisa de apoio eleitoral nos Estados Unidos entre 2 presidentes, só que fizeram-na pelo telefone só que só tinha acesso ao telefone quem era rico, então o resultado foi o outro, o resultado da eleição no mundo real foi completamente distinto. Então a gente tem essa noção, a gente pode ter 20 milhões de curtidas, mas no fundo o que importa mesmo não é Internet. A Internet faz parte da vida, mas o que importa é o mundo concreto, o que importa é a gente fazer atividade no terminal. Onde estão as pessoas que usam ônibus: 
mais na Internet ou mais no terminal de ônibus? A gente sempre tem que pensar pra atingir. Será que é mais proveitoso a gente fazer na Internet ou a gente fazer uma panfletagem? A gente, muitas vezes, acha mais vantajoso fazer a panfletagem. Internet é muito esse domínio do espetáculo, de um mundo muito irreal, muito inatingível, muito limitado, considerando as dimensões do país, de São Paulo e o contexto socioeconômico será que vale a pena se pautar pela internet? Será que vale a pena se pautar pelo espetáculo? A gente acha que não. Acha que vale mais a pena se pautar pelo mundo concreto, pelo mundo que não tá aparecendo nas notificações do dia a dia, pelo mundo que não vai ser compartilhado 20 milhões de vezes no Facebook, e sim pelo mundo que as pessoas enfrentam todo dia, pelo passinho pra trás que as pessoas tem que dar, todo dia, pra caber nos ônibus, pelo sufoco, pelas cotoveladas, pelos apertos que elas tem que dar no trem pra entrar nele. A gente prefere se pautar por isso do que por questões tão espetaculares. [...]. (MILITANTE MPL, 2013)

Para o MPL, dentro das próprias Jornadas pode ser vista uma diferença entre as características do seu período inicial e de seu fim:

Acho que tem dois momentos. Aliás, acho que tem vários momentos na luta contra o aumento de 2013, momentos particulares. Tem uma posição da mídia, muito clara, até o dia 13, incluindo o dia 13, incluindo a edição da manhã do dia 13, então você tem esse primeiro momento. Nesse primeiro momento você tem o Primeiro Ato, que era muito grande, do tamanho de um dos maiores atos desde 2011 que foi a última luta contra o aumento, então você já tem uma maior informação, já tem uma maior legitimidade de lutar, de desnaturalizar o aumento da passagem e de desnaturalizar o transporte como mercadoria, você tem essa luta como legítima, o pessoal tá falando assim: 'O transporte tem que ser direito, é minha cidade, é meu transporte, eu deveria poder usar do jeito que eu bem entender e decidir sobre ele', então, você tem, cada vez mais, as pessoas tendo essa posição, acho que isso é um processo histórico e talvez o MPL tenha alguma parte nisso, eu acho que tem, algo em torno dele e aí você chega nos cinco mil, mais ou menos, o que tinha no primeiro ato. E ai vai aumentando, por quê? Porque as 
pessoas têm essa apropriação cada vez mais, tem essa legitimidade do transporte ser um direito, e por mais que isso é uma construção da mídia: de ser uma coisa ilegítima, cada vez mais as pessoas vão se apoderando e vão refletindo, elas próprias sendo cada vez mais os sujeitos dessa luta. E vai aumentando, não sei talvez em grande parte por causa da repressão que dá uma questão midiática, a radicalidade dá uma questão midiática, não sei, acho que as pessoas se apropriaram da luta e isso faz com que elas se interessem mais em lutar. (MILITANTE MPL, 2013)

\section{CONSIDERAÇÕES FINAIS}

Sem ter a pretensão de esgotar o tema, este capítulo busca trazer novos elementos para enriquecer o debate sobre as Jornadas de Junho, que incendiaram no Brasil as discussões sobre o uso da internet nas mobilizações sociais.

Durante as Jornadas, a internet foi utilizada como forma de divulgação de informação e contrainformação, entendida neste capítulo como o uso das tecnologias para contrapor as notícias e dados divulgados sobre os atos pela mídia tradicional. Além disso, muitas vezes a internet, especialmente nas redes sociais, foi utilizada como forma de desmentir a versão oficial divulgada pela mídia tradicional. Assim, é importante pontuar que a internet teve um papel importante nas Jornadas apesar dos próprios representantes do MPL entenderem que esse uso é complementar na atuação do movimento.

Esta linha entre utilizar o mundo virtual para complementar o real e utilizar apenas a internet para mudar o mundo real é tênue. Caso os movimentos sociais não entenderem a internet como um dos instrumentos de luta e não necessariamente como "o" instrumento de luta, consequentemente, terão que reconhecer que sua luta dificilmente obterá ganhos reais:

O problema é quando a fascinação pela Internet e pelas novas tecnologias nos faz esquecer de que o mundo virtual não é o mundo real. As leis, as guerras, a fome, a pobreza, a riqueza, tudo isso se encontra fora dos computadores. Os movimentos 
sociais já existiam antes da Internet, e os meios alternativos, rádios e televisões comunitárias também. As novas tecnologias permitem o acesso à informação por vias mais democráticas e participativas do que as tradicionais. O erro seria que isso produzisse uma fascinação tecnológica que equiparasse os atos de se informar e informar com os de se mobilizar e participar. (SERRANO, 2013, p. 174)

Complementando este raciocínio, já foi dito acerca do uso das redes sociais como elemento acionador dos movimentos que irromperam na Primavera Árabe que:

A mídia nas mãos dos cidadãos pode sacudir regimes. Isso torna muito mais difícil para os governantes manter a legitimidade, controlando a esfera pública. Mas os ativistas, que fizeram tal uso eficaz da tecnologia para reunir adeptos, ainda precisam descobrir como converter essa energia em maior impacto. A questão não é apenas desafiar o poder, é mudá-lo. (TUFEKCI, 2014)

Para o MPL, o aumento do número de pessoas nas ruas foi devido à identificação com a causa do Passe Livre e a compreensão de sua relevância. A questão da repressão ocorrida no ato do dia 13 de junho é lembrada, chega a ser apontada como uma possível colaboradora deste aumento dos participantes nas manifestações. Entretanto, para o MPL, todos aqueles que foram às ruas no ato seguinte à repressão mais brutal, construíram a ocasião para que a mídia alterasse seu posicionamento sobre as manifestações, como elas deveriam ser tratadas pelo governo e pela força policial, e concretamente, conquistaram a redução tarifária do transporte público em São Paulo.

\section{REFERÊNCIAS}

ALLEGRINI, G. O gatilho da revolta: repressão policial, velha conhecida das periferias, surpreende ao atingir classe média. Caros Amigos, São Paulo, n. 196, p. 28-29, jun. 2013.

ATO com 65 mil participantes fecha marginal Pinheiros, em SP, e chega ao Palácio dos Bandeirante. 2013a. Disponível em: <http://noticias. 
uol.com.br/cotidiano/ultimas-noticias/2013/06/17/ao-menos-500omanifestantes-fecham-a-avenida-faria-lima-protesto-segue-em-direcao-apaulista.htm>. Acesso em: 05 set. 2013.

BREDA, T.; BRITO, G. Sem PM, multidões protestam pacificamente e ganham ruas de São Paulo. Rede Brasil Atual, São Paulo, 16 jun. 2013. Disponível em: <http://www.redebrasilatual.com.br/cidadania/2013/06/ sem-pm-multidoes-protestam-pacificamente-por-sao-paulo-6863.html>.

CALDAS, G. O latifúndio do ar: mídia e poder na Nova República (19851989). 2011. Disponível em: <http://issuu.com/encipecom2/docs/ latifundiodoar>. Acesso em: 05 jan. 2012.

CASTELLS, M. et al. Electronic communication and sociopolitical mobilization: A new form of civil society. In: ANHEIER, H. K.; KALDOR, M.; GLASIUS, M. Global Civil Society, v. 6, London: SAGE, 2005/6. Chapter 8. p. 266-285. At: http://www. gcsknowledgebase.org/wp-content/uploads/20056-10-ch8-red.pdf.

COLETIVO DE REGISTRO DA LUTA CONTRA O AUMENTO. $3^{\circ}$ grande ato contra o aumento das passagens em São Paulo. 2013. Disponível em: $<$ http://passapalavra.info/2013/06/78994>. Acesso em: o6 set. 2013. COMITÊ GESTOR DA INTERNET NO BRASIL. Pesquisa sobre o uso das tecnologias da informação e comunicação no Brasil: TIC domicílios e empresas 2013. Coordenação executiva e editorial, Alexandre F. Barbosa. São Paulo: CGI,br, 2014.

CONKLIN, D. B. The Internet, Email, and Political Activism: The Case of Tiananmen Square. The European Consortium for Political Research. In: EUROPEAN CONSORTIUM FOR POLITICAL RESEARCH, 20., 2003. Edinburgh. [Paper] Edinburgh, Scotland, UK, 2003.

EM DIA de maior mobilização, protestos levam mais de 1 milhão de pessoas ÀS ruas no Brasil. 2013b. Disponível em: <http://noticias.uol. com.br/cotidiano/ultimas-105 noticias/2013/06/20/em-dia-de-maiormobilizacao-protestos-levam-centenas-de-milhares-as-ruas-no-brasil. htm>. Acesso em: 19 set. 2013.

ENTENDER as manifestações. Estadão, São Paulo, 15 jun. 2013. Opinião, p. A2. Disponível em: <http://opiniao.estadao.com.br/noticias/ geral,entender-as-manifestacoes-imp-,1042701>. Acesso em: 03 mar. 2016. 
ESPÍRITO SANTO, M. O. Lutas sociais e ciberespaço: o uso da internet pelo Movimento Passe Livre nas manifestações de junho de $2013 \mathrm{em}$ São Paulo. 123 f. 2014. Dissertação (Mestrado em Ciência Sociais) Universidade Estadual Paulista, Marília, 2014.

EVOLUÇÃO da tarifa de transporte em São Paulo. 2013. Disponível em: $<$ http://www.terra.com.br/noticias/infograficos/tarifas-metro-onibussp/>. Acesso em: 06 set. 2013.

FERNANDES, E.; ROSENO, R. de F. Protesta Brasil: das redes sociais às manifestações de rua. São Paulo: Prata Editora, 2013.

GOHN, M. da G. Sociologia dos movimentos sociais. São Paulo: Cortez Editora, 2013.

HARVEY, D. Condição pós-moderna: uma pesquisa sobre as origens da mudança cultural. 15. ed. São Paulo: Edições Loyola, 2006.

HILSENBECK FILHO, A. M. O EZLN e a guerrilha informacional: a política no mundo encantado da mídia e da comunicação. 2004. Disponível em: <http://br.monografias.com/trabalhos914/ezlnguerrilha-informacional/ezln-guerrilha-informacional2.shtml>. Acesso em: 02 jan. 2012.

JUDENSNAIDER, E. et al. Vinte centavos: a luta contra o aumento. São Paulo: Editora Veneta, 2013.

MAGALHÃES, V.; NOVAES, M. SP: fotógrafo do Terra é preso durante cobertura de protesto. São Paulo, 2013. Disponível em: $<$ http://noticias. terra.com.br/brasil/cidades/sp-fotografo-do-terra-e-preso-durantecobertura-de-protesto, 245a815136f $3 \mathrm{f}_{3} 10$ VgnVCM4000009bcceboaRC RD.html>. Acesso em: 19 set. 2013.

MANOLO. Teses sobre a Revolta do Buzu. [2009]. Disponível em: <http:// tarifazero.org/wp-content/uploads/2009/07/por_QS3_RevoltaBuzu. pdf>. Acesso em: 15 set. 2013 .

MILHOMENS, L. MST, esfera pública e ciberativismo: um novo espaço para o debate. Conexões Midiáticas, n. 1, p. 1-11, mar./ ago. 2009. Disponível em: < http://www.insite.pro.br/P\%C3\%Aıginas\%2onovas/ mst_ciberativismo_milhomens.pdf>. Acesso em: 20 dez. 2011.

MORAES, D. de. Comunicação virtual e cidadania: movimentos sociais e políticos na internet. 2000. Disponível em: <http://www.egov.ufsc.br/ 
portal/sites/default/files/anexos/16072-16073-1-PB.pdf>. Acesso em: 28 jan. 2012.

MOVIMENTO PASSE LIVRE. Carta de princípios. 2013a. Disponível em: $<$ http://saopaulo.mpl.org.br/apresentacao/carta-de-principios/>. Acesso em 28 de julho de 2013 .

MOVIMENTO PASSE LIVRE. Apresentação. 2013b. Disponível em: $<$ http://saopaulo.mpl.org.br/apresentacao/>. Acesso em: 28 jul. 2013.

MOVIMENTO PASSE LIVRE. Não começou em Salvador, não vai terminar em São Paulo. In: MARICATO, E. et al. Cidades rebeldes: Passe Livre e as manifestações que tomaram as ruas do Brasil. São Paulo: Boitempo, Carta Maior, 2013c. Cap. 1, p. 13-18.

OLIVEIRA, E. et al. Erica de Oliveira, Gabriel Simeoni, Maurício Carvalho e Arielli Moreira: a tarefa é fortalecer as lutas sociais: jovens que organizaram os atos pelo passe livre falam sobre as maiores manifestações vistas no País. Caros Amigos, São Paulo, n. 196, 16 jul. 2013.

PAPP, A. C. Nas favelas, mais de $50 \%$ de internautas. O Estado de S. Paulo, São Paulo, 30 out. 2013. Disponível em: <http://www. estadao.com.br/noticias/impresso,nas-favelas-mais--de-50-deinternautas-,1091256,o.htm>. Acesso em: 02 nov. 2013, às 18:30.

PIRES, B. Em uma semana, quatro protestos contra o aumento da tarifa em São Paulo. Estadão, São Paulo, 13 jun. 2013. Disponível em: <http:// www.estadao.com.br/especiais/em-uma-semana-quatro-protestoscontra-aumento-da-tarifa-em-sao-paulo,203763.htm>. Acesso em 10 de setembro de 2013 .

RAMONET, I. A explosão do jornalismo na era digital. In: MORAES, D.; RAMONET, I.; SERRANO, P. Mídia, poder e contrapoder: da concentração monopólica à democratização da informação. São Paulo: Boitempo; Rio de Janeiro: FAPERJ. 2013a, Cap. 4, p. 85-102.

RETOMAR a Paulista. Folha de São Paulo, São Paulo, 13 jun. 2013. Editorial. Primeiro Caderno. p. A2.

SECCO, L. As Jornadas de Junho. In: MARICATO, E. et al. Cidades rebeldes: Passe Livre e as manifestações que tomaram as ruas do Brasil. São Paulo: Boitempo, Carta Maior, 2013. Cap. 10, p. 71-78. 
SERRANO, P. Outro jornalismo possível na internet. In: MORAES, D.; RAMONET, I.; SERRANO, P. Mídia, poder e contrapoder: da concentração monopólica à democratização da informação. São Paulo: Boitempo; Rio de Janeiro: FAPERJ, 2013. Cap. 6, p. 145-182.

TUFEKCI, Z. After the protests. The New York Times. The Opinion Pages. March, 19 2014. Disponível em: <http://www.nytimes. $\mathrm{com} / 2014 / 03 / 20 /$ opinion/after-the-protests.html?rref=collection\%2Fcol umn\%2Fzeynep-tufekci\&_r=0>. Acesso em: 14 maio 2015 . 


\title{
DOS VINTE RÉIS AOS VINTE CENTAVOS
}

\author{
o papel das redes sociais e movimentos \\ coletivos no Brasil
}

JOSÉ ANTONIO GOMES DE PINHO, INGRID WINKLER, JÚLIO CÉSAR ANDRADE DE ABREU, FABIANO MAURY RAUPP

\section{INTRODUÇÃO}

Este artigo versa sobre as manifestações de protesto ocorridas no Brasil a partir de junho de 2013 (daqui para frente, chamadas de junho/13) e a dois outros momentos onde ocorreram manifestações populares: o movimento Fora Sarney (FS), na versão transcorrida em Salvador em 2009 e a longínqua Revolta do Vintém (RV), que explodiu no final de 1879 e começo de 1880, última década do Império. Nos dois primeiros casos, o artigo bosqueja o papel das tecnologias digitais com ênfase nas redes sociais. O objetivo do artigo é entender não só como estas ocorreram, mas também o seu, digamos, "making of", como os participantes foram mobilizados em tempos de prevalência de recursos digitais, a saber, as chamadas redes sociais, no caso em que se aplicam. De imediato faz-se necessário perguntar o que teriam em comum esses movimentos, ainda mais quanto a esta última, levando em conta que já se passou bem mais do que um século entre a Revolta do Vintém e os outros dois acontecimentos aqui contemplados. 
Podemos assim notar diferentes correlações entre estes três eventos, que indicamos na Figura 1. O que tem de comum entre a RV e as manifestações de junho/13 (área 3 na Figura 1) é a luta contra o aumento das passagens do transporte público, esse é o liame entre a RV e o Junho/13. A título de curiosidade, o número " 20 " também esteve presente em ambas as manifestações. Enquanto os " 20 centavos" foi o estopim das manifestações de Junho/13, os "vinte réis", ou seja, um vintém, motivaram a RV. Por sua vez, o que existe de comum entre o FS e o junho/13 (área 2, na Figura 1) é o uso intensivo de recursos digitais, não constando na agenda a contestação do aumento das passagens de transporte público. Uma outra diferença ainda tem que ser apontada entre esses dois momentos. O FS primava pelo combate à corrupção entronizada na figura do Senador José Sarney e uma tentativa de cassação de seu mandato em curso naquela época no Congresso, enquanto as manifestações mais recentes partiram da questão da tarifa do transporte, mas logo desembocaram em um grande continente de demandas diversificadas, emergindo, com primazia, a luta contra a corrupção e insatisfação com as prioridades governamentais (sobretudo, as obras da Copa do Mundo de futebol no Brasil) e o próprio desempenho governamental. Poder-se-ia afirmar que o FS era mais focado no combate à corrupção e a uma das figuras emblemáticas do fenômeno, o senador Sarney, enquanto a pauta de junho/13 era mais dispersa e difusa, mas também passando a conter o combate à corrupção. Já a RV e o FS (área 1, na figura) não guardam semelhanças, além de serem manifestações populares contra desmandos governamentais que prejudicaram diretamente a população (aumento de tributos e corrupção). Seus contextos, motivações e características são bem distintos, mas, ainda assim, nos dão uma interessante dimensão para análise e contraste neste trabalho.

Se não existem grandes diferenças de contexto entre o FS de 2009 e as manifestações de junho/13, as diferenças entre o contexto da RV e as mais recentes (2009 e 2013) são, obviamente, imensas. O que se pode perceber é que existem aproximações e distanciamentos entre os três movimentos, sem embargo do tempo transcorrido entre o mo- 
vimento do final do Império e os mais recentes. Em outras palavras, mesmo passados mais de 130 anos da RV ainda é possível aprender com aquele fenômeno para entender os dias de hoje e até mesmo o futuro próximo.

Figura 1 - Correlações entre os eventos RV, FS e junho/13

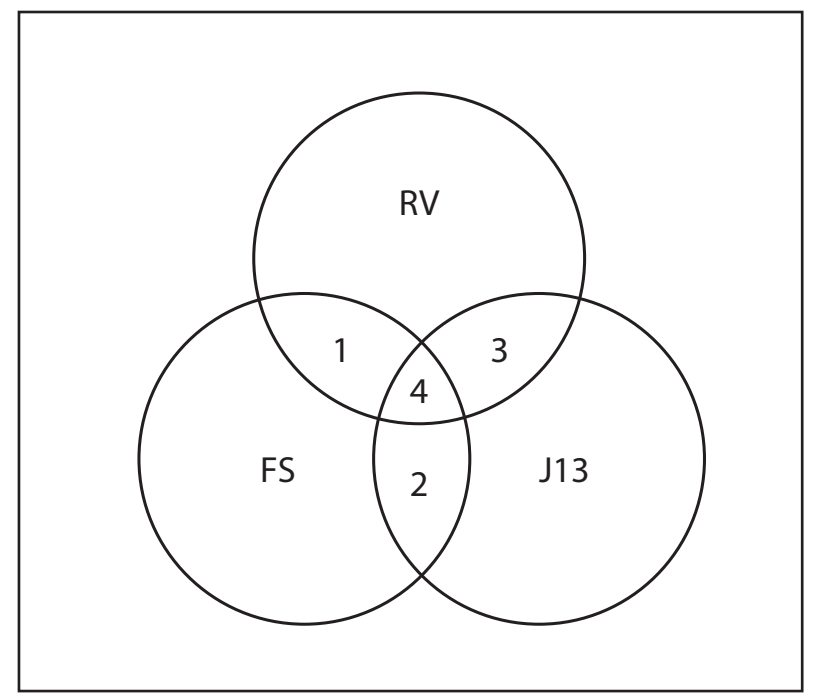

Fonte: elaborado pelos próprios autores.

Metodologicamente, iremos começar pelos movimentos mais recentes, pois são os que mobilizam mais e que estão no foco dos pesquisadores e observadores da cena política nacional. Os dois outros movimentos considerados serão contraponto ao que ocorre contemporaneamente.

Antes de iniciarmos a apresentação e reflexão dos acontecimentos iniciados em junho de 2013, é de bom alvitre fazer algumas considerações que nos levam a relativizar a importância e magnitude dos mesmos, ainda que não passe pela cabeça de ninguém negar a importância e impacto dessas ocorrências (que evidentemente ainda não podem ser sentidos em toda sua extensão, ainda que tenham reverberado ao longo de 2014). Assim, uma primeira consideração ou alerta a ser feito se refere ao fato de certa interpretação de ineditismo desses 
movimentos recentes. Este alerta tem dois braços. O primeiro aponta que esses movimentos recentes são precedidos de outros tais, como o próprio FS e outros de maior porte e impacto, como o dos Caras Pintadas (1992), e o maior de todos ocorrido no Brasil, o movimento das Diretas-Já (1984). Dessa juntada podemos extrair que o Brasil se move de forma espasmódica em relação a movimentos sociais de grande porte e consequências. Se o Diretas-Já foi derrotado, o Caras Pintadas contribuiu decisivamente para o impeachment do presidente Collor, objetivo do movimento. O segundo braço repousa na constatação de um sem número de movimentos, rebeliões, revoltas e protestos que ocorrem molecularmente no país, tanto no meio urbano como no meio rural, e que, em geral, não conseguem chegar ao proscênio porque se localizam na periferia das cidades de um modo geral. As motivações dessas manifestações são as mais diversas: revolta por morte de algum morador em comunidades por atropelamento, no qual a demanda normalmente reivindicada é a construção de passarelas sobre as estradas, revolta por ação da polícia matando algum/a morador/a da comunidade, revolta por falta de segurança pública, de educação, saúde etc. Ainda revolta por desocupação de conjuntos habitacionais ou reintegração de posse de alguma área ocupada, invadida. Muitas dessas manifestações contêm elementos fortes de violência, tais como fechamento de ruas, construção de barricadas com queima de pneus, árvores e lixo. Essas manifestações só não ganham maior expressão porque acontecem, em geral, na periferia, onde as carências da população saltam aos olhos e tem um caráter mais de explosão, revolta não se sustentando no tempo. O que queremos enfatizar com essa apresentação é que o povo, principalmente na periferia, tem uma posição praticamente ativa, se não durante o tempo todo, pelo menos com uma frequência que normalmente não é percebida. O que se deseja enfatizar é que não estamos exatamente frente a uma sociedade completamente passiva que não esboça nenhuma reação. A sociedade reage, sim, mas, em geral, de forma tópica, sem maior estruturação e organização e sem continuidade. 
Por outro lado, quando o movimento ocorre em uma área central e/ou nobre, passa a chamar a atenção, e mais ainda se é realizado não por periféricos, mas por pessoas mais bem situadas na escala social. No caso específico do detonador dos movimentos mais recentes, vale notar que havia toda uma pretérita construção de luta contra o aumento das passagens dos ônibus com as explosões da Revolta do Buzu em Salvador (2003) e também da Revolta das Catracas em Florianópolis (2004). Em outras palavras, o Movimento do Passe Livre (MPL) não surgiu do nada, não aconteceu de uma hora para outra, veio de uma construção histórica de luta no segmento do transporte público.

A compreensão dos movimentos de junho/13 pode ser buscada em duas fontes fundamentalmente. Uma primeira consiste nos escritos feitos no calor dos acontecimentos, normalmente respirando muito otimismo aliado a ineditismo e surpresa com os acontecimentos. Uma segunda fonte encontra-se em documentos produzidos um pouco além desses primeiros momentos quando os movimentos haviam refluído quando o distanciamento já possibilitava uma visão mais realista, menos otimista e contemplando os desdobramentos que se produziram ao longo do tempo e dentro do movimento. Neste artigo, recorreremos a essas duas fontes.

Nada melhor do que começar exatamente expondo o pensamento do MPL. No calor dos acontecimentos, o MPL produz um texto que pode ser encarado como um manifesto onde descreve, de maneira sucinta e direta, sua trajetória e teleologia, contribuição central ao entendimento de todo esse processo. O projeto do MPL (2013, p. 13-15) é ambicioso, partindo do princípio de que "[...] o transporte é ordenado de cima para baixo, segundo os imperativos da circulação do valor". $\mathrm{Na}$ luta contra a exclusão urbana é que "[...] se forjou o Movimento Passe Livre”. O documento registra o que é sobejamente conhecido: que para compreender o processo que levou às "revoltas de junho de 2013", é necessário recuar no tempo, pelo menos até a chamada "Revolta do Buzu”, ocorrida em Salvador, em 2003, como resposta ao aumento das passagens dos ônibus. As estimativas de participação indicam $40 \mathrm{mil}$ pessoas a partir de "[...] estudantes secundaristas" com um modelo 
de organização “[...] afastado dos modelos hierarquizados”. Esta experiência ganhou reconhecimento nacional estourando no ano seguinte, 2004, em Florianópolis gerando protestos que “[...] forçaram o poder público a revogar o aumento e serviram de base para a fundação do MPL no ano seguinte”. Pode-se perceber assim que quando os eventos de junho de 2013 ocorreram a partir de São Paulo, o MPL já amealhava uma experiência de oito anos.

O MPL surge como um movimento social "[...] horizontal e apartidário, cujos coletivos locais, federados, não se submetem a qualquer organização central”. As deliberações são tomadas “[...] de baixo, por todos, em espaços que não possuem dirigentes, nem respondem a qualquer instância externa superior”. Para o Movimento, “[...] a maior parte da população explorada nos ônibus” não tem dinheiro suficiente para a condução além dos deslocamentos “[...] entre a casa, na periferia, e o trabalho, no centro”. O Movimento ainda explica que a inserção dos trabalhadores na "reapropriação do espaço urbano" vem a superar “[...] a bandeira do MPL em seus primeiros anos, que era o passe livre estudantil”. Enquanto estratégia, o MPL entende que a cidade é “[...] usada como arma para sua própria retomada" ao promover o bloqueio de "um mero cruzamento" que compromete toda a circulação, devido ao fato da predominância do transporte individual nas vias. Na percepção do Movimento, foi isto que ocorreu em São Paulo em junho/13 e que levou o prefeito a revogar o aumento da passagem em vinte centavos (e o governador a não implantar o aumento no metrô e nos trens). E esta medida propagou-se “[...] em mais de cem cidades do país" quando “[...] as pessoas deslocaram momentaneamente - e com impactos duradouros - o controle político da gestão do transporte". O documento se encerra com a afirmação de que essas "[...] mobilizações sempre foram muito mais amplas que o Movimento Passe Livre - que jamais se pretendeu dono de qualquer uma delas - e eclodiram, por vezes, em cidades e regiões onde nunca houve atividade do movimento". A partir dessas mobilizações de junho/13, "[...] milhares continuam nas ruas em diversas cidades, defendendo agora a implementação da tarifa zero". (MARICATO et al., 2013, p. 16-17) 
O movimento em si pode ser visto como tendo pelo menos quatro fases: 1) as manifestações iniciais, notadamente em São Paulo, com a presença de um número relativamente pequeno de participantes; 2) a reação da polícia, marcada por extrema violência, o que resultou, talvez ao contrário do esperado, em um fortalecimento dos movimentos e seu espalhamento para outras cidades do país; 3) o recuo das autoridades, cancelando o aumento previsto do transporte público bem como o recuo da ação violenta da polícia, o que gerou mais um fortalecimento das manifestações: 4) a entrada em cena dos Black blocs o que provocou, não de imediato, mas no curto prazo, a retirada do MPL e de manifestantes, esvaziando as manifestações. A esse respeito vale a pena resgatar uma expressão lembrada por Umberto Eco ao comentar a participação da juventude na vida política, qual seja, "[...] todos nascemos incendiários e morremos bombeiros". (ECO, 2008) Incendiários e bombeiros são figuras metafóricas, mas aplicando esse pensamento aos eventos de junho/13, pode-se perceber que quando chegaram os verdadeiros incendiários nas manifestações, os Black blocs, jovens incendiários metafóricos, tentaram dissuadir este grupo do uso da violência. Assim, foram bombeiros ainda jovens, mostrando que a raiz dos protestos tinha, em geral, um caráter pacifista.

\section{REFERENCIAL TEÓRICO}

O referencial teórico deste artigo possui duas vertentes: uma que examina a questão dos movimentos em si, com ênfase nas chamadas jornadas de junho/13, e nas possibilidades de uso das redes sociais para ensejar uma nova forma de fazer política nas condições contemporâneas.

\section{Internet, as redes sociais e a Política no Brasil}

Começando por esta última, uma questão central que a Internet e, principalmente, as redes sociais têm suscitado é até que ponto todas essas ferramentas podem mudar a forma tradicional de fazer política por parte da sociedade civil, gerando um upgrade e, assim, mudando o quadro político existente? Não resta dúvida de que a Internet e as redes reúnem 
condições intrínsecas de promover uma participação maior da sociedade e por suas facilidades de contato, funcionamento permanente e on-line, mobilizar mais pessoas, trazê-las mais para perto, ainda que no mundo digital. Por outro lado, outras questões têm que ser levantadas sobre a política em si. Assim, cabe perguntar: se uma sociedade civil não se mobiliza pelos canais convencionais e tradicionais, produzindo uma participação política mais ativa, será que iria, agora, ao usar os recursos da comunicação digital, gerar uma sociedade mais ativa politicamente? (PINHO, 2011) Participar nas redes sociais é suficiente para produzir mudanças mais efetivas e concretas na esfera política? Ou seria esta fase uma primeira para gerar resultados mais efetivos?

Não há como desmerecer a utilização de recursos digitais na esfera política, tais como urna eletrônica, a possibilidade de fazer petições on-line, envio de mensagens eletrônicas para parlamentares, governantes e setores do Estado, estabelecimento de fóruns para debate de questões políticas. Todas essas, entre outras, representam ações possíveis por conta do meio digital.

Mas, nesta sociedade fundamentalmente digital, estariam esgotadas, superadas as formas mais tradicionais de fazer política? Ao que tudo indica, ainda estamos naquela situação de lusco-fusco da mudança de um padrão tecnológico para outro, mas isto não quer dizer que o antigo padrão não tenha mais espaço. Essa questão ainda comporta uma outra preocupação que conspira contra o caráter democrático das redes face ao caráter elitista, dominante das mídias tradicionais. Assim, a possibilidade dos grupos mais instruídos e com acesso mais fácil às redes monopolizarem movimentos na rede pode produzir uma participação ainda elitista. Este artigo, ao examinar três movimentos distintos, objetiva lançar luz para a busca de respostas para esses questionamentos.

Laymert Garcia dos Santos (2003) pontua que “[...] a tecnologização da sociedade é intensa” observando-se uma centralidade da tecnologia. O autor relembra Lênin que definia o comunismo como os sovietes acrescidos da eletricidade e questiona como seria com a busca do socialismo atual: "Será que podemos substituir a eletricidade pela internet, 
e os sovietes pelas comunidades de base e achar que encaminhamos a questão?" Para fundamentar não uma resposta, mas uma reflexão, vê a questão de uma forma bem complexa, pois seria “[...] ingênuo acharmos que a internet é um território livre, que vamos conseguir fazer uma revolução usando a internet”. Por outro lado, não nega “[...] o aspecto democrático de circulação da informação que existe na internet e as conexões que ela possibilita" visualizando que "[...] existem brechas dentro dos sistemas" que devem ser aproveitadas, mas devendo-se lembrar que a internet é uma tecnologia nova e que "[...] o capital está começando a colonizá-la agora”. Assim, no momento em que houver "[...] uma grande capilaridade nos países industrializados, quando a vida for impossível sem a internet, então aí é que vai começar a regulação da internet”. (SANTOS, 2003, p. 17, 74-75)

Relembra o autor que as tecnologias anteriores foram apresentadas como democráticas, como parte do mito do progresso, mas apresenta sua discordância com o fato de que as novas tecnologias sejam todas para o bem, como não acredita que “[...] os indivíduos sejam todos iguais" constatando diferenças entre um operador do Primeiro Mundo e do Brasil devido às desigualdades educacionais existentes. Como choque de realidade, expõe que "[...] o fato de existir uma rede não significa que ela é necessariamente democrática”. (SANTOS, 2003, p. 76)

Isto posto, o próprio Santos coloca-se como "[...] mais realista do que catastrofista”. Bernardo Kucinskyi, por sua vez, assume uma posição oposta ao entender a revolução da comunicação como "libertária”, exemplificando que com a possibilidade de se produzir um jornal com 3 ou 4 mil reais e assim, a pessoa "[...] libertou-se do capital". Em seu entender, a atual revolução tecnológica vai na direção oposta da revolução industrial do século XVIII que com a máquina transformou cada trabalhador dependente do dono dos bens de produção. Discorda de Santos ao entender que não existe uma propensão ao capital se apropriar de tudo, como no caso das músicas na internet com a produção caseira de CDs. Kucinski defende que as tecnologias modernas "[...] libertam as pessoas dos sistemas", gerando "a autonomia do indivíduo na comunicação”, apontando como natureza dessas 
tecnologias a "[...] interatividade e custo baixíssimo". Ressalta como importante o fato que as novas tecnologias "[...] parecem ter nascido com as novas gerações: está no sangue delas". Converge com Santos, por sua vez, ao constatar a necessidade de "[...] um novo nível de escolaridade”. As novas tecnologias potencializaram as capacidades do produtor intelectual, ressaltando os milhões de acessos diários à internet, bem como "[...] ações de protesto", que aumentam cada vez mais, não se sabendo "[...] aonde isso vai parar" e nem se tendo "[...] a dimensão exata disso". Em suma, “[...] essas tecnologias abrem uma nova possibilidade de libertação. Nós só temos que saber com usá-las". (SANTOS, 2003, p. 54-55, 70, 78, 80, 82)

Alguns comentários parecem pertinentes a partir dessas observações. Não resta dúvida de que muito do que Kucinskyi aponta é verdade, mas não se sente o peso de fazer política de uma forma diferente e efetiva em suas observações. Passados já mais de dez anos dessas reflexões ainda parece que a obra não está terminada (talvez esteja apenas começando) e não seja possível já extrair posições definitivas a respeito da mudança da forma de fazer política, apesar de toda a parafernália de artefatos tecnológicos, até porque a tecnologia muda muito rapidamente, disponibilizando mais opções aos usuários (cidadãos?), enquanto que a política se move na velocidade tradicional. (PINHO, 2008)

$\mathrm{Na}$ linha de argumento de Kucinskyi (2003) Sorj (2003, p. 49, 57), posiciona que "[...] a Internet é relacionada a uma nova forma de fazer política, dissociada ou à margem do Estado, pelo fortalecimento das redes da sociedade civil”, ponderando, no entanto, que não existam, até o momento, "[...] elementos suficientes que confirmem qualquer suposição sobre o impacto da Internet na política”, convergindo com o dito acima. Os novos recursos digitais podem promover uma transformação radical da democracia representativa em democracia plebiscitária, a partir do aumento da participação dos cidadãos nas decisões dos governos, através do voto eletrônico. Indo um pouco além, a internet permite "[...] radicalizar a democracia, criando um novo espaço público construído em torno de uma sociedade civil que se organizará à margem do Estado". Por outro lado, vendo a questão de um prisma pes- 
simista, “[...] a nova sociabilidade virtual destrói as bases da interação que permite a construção do espaço público e aumenta a capacidade de controle da população pelo Estado". Nesta corrente, “[...] a internet destrói as relações face a face, que seria a única fonte de comunicação capaz de gerar grupos sólidos e estáveis, com memória histórica (no lugar do mundo atemporal da internet), que seria a única base possível de sustentação de uma vida pública e de ação política constante”. Nesse contexto, a própria tecnologia cria condições para o controle crescente do Estado e das empresas sobre os cidadãos. Escrevendo um pouco antes, Agre (1997, p. 114) assevera que a internet “[...] oferece a esperança de uma sociedade mais democrática. Através da promoção de uma forma descentralizada de mobilização social, diz-se que a internet pode nos ajudar a renovar nossas instituições e nos libertar de nossos legados autoritários". No entanto, o próprio autor reduz esta expectativa ao ponderar que a internet “[...] detém essas possibilidades, mas elas não são absolutamente inevitáveis”. Mas que isso, pode se transformar em "instrumento de opressão" e de centralização do poder. Em outras palavras, acreditar piamente que a internet vai resolver nossos problemas de democracia é acreditar que se trata de uma luta tecnológica e não uma de luta política.

É interessante nos voltarmos para esta literatura produzida há mais de dez anos e ver quais promessas e expectativas se concretizarem. Apesar do aumento vertiginoso dos artefatos tecnológicos (ainda não havia as redes sociais digitais naquela época), e ainda sobre o aumento da participação nas redes, parece que os reflexos na política e na forma de fazer política não se alteraram substancialmente no caso do Brasil. As estruturas tradicionais e conservadoras da política no Brasil se mantêm sólidas frente aos avanços das tecnologias digitais e do uso delas. A literatura acima exposta levanta as questões referentes à participação digital versus a participação face a face. O raciocínio não é nem uma, nem outra, não é uma ou outra, mas sim uma e outra. Há o momento para a atividade digital, mas também há o momento de ir para a rua. Por mais incendiárias que sejam as mensagens, a troca de informações, é muito diferente queimar pneu na rede e queimar pneu na rua. 
Ao se constatar que as redes virtuais “[...] se multiplicaram e mudaram o funcionamento das organizações piramidais" ainda se “[...] está longe de fazê-las desaparecer", dado que "a criação das redes virtuais não elimina a materialidade do mundo [...]". Assim, ainda que “[...] a internet desterritorializa no sentido de permitir intercâmbios em escala global, os espaços territoriais continuam a ser tão importantes, ou mais do que nunca [...]". (SORJ, 2003, 55-56) Nesse contexto, as comunidades virtuais devem ser vistas como agregadas sociais que surgem no âmbito da internet quando uma quantidade suficiente de pessoas leva adiante essas discussões públicas durante um tempo suficiente, com suficientes sentimentos humanos para formar redes de relações pessoais no espaço cibernético. (RHEINGOLD, 1996) Para Castells (1999, p. 385) a comunidade virtual, é uma rede eletrônica de comunicação interativa autodefinida, organizada em torno de um interesse ou finalidade compartilhados, embora algumas vezes a própria comunicação se transforme no objetivo. Mamede-Neves e outros (2005) detectam a existência de um afogamento caótico em dados e de um fogo cruzado das imagens, cujo caos atinge a toda a sociedade, fazendo com que, muitas vezes, os adultos pensem em recuar, posição da qual a juventude, pela sua própria constituição, parece não ter medo. Todas essas reflexões nos levam a pensar que as gerações mais jovens, os nativos digitais, podem estar entendendo que tudo acontece nas redes, ou grande parte nas redes. Assim, a política também seria feita e decidida nas redes. Não é de se estranhar a predominância de muitos cartazes dizendo algo como: "[...] saímos da rede, estamos na rua”, ou mesmo convocações do tipo: "sai do sofá, vem pras ruas”.

\section{Redes Sociais, ruas e o junho/13}

Um primeiro ponto a salientar é que esses movimentos pegaram os analistas políticos de surpresa, havendo várias demonstrações da dificuldade de entender teoricamente o que estava acontecendo dado o ineditismo dos movimentos, principalmente quando teóricos tentavam exarar algum entendimento sobre os movimentos no calor dos acontecimentos. E à medida que os movimentos iam tendo seu rumo 
alterado, maiores dificuldades de compreensão teórica emergiam. Isso em grande parte se dava devido à pluralidade dos atores envolvidos e da posição absolutamente diferenciada e desconhecida dos padrões tradicionais, assumida pelo MPL. Como mencionado acima, podemos agrupar os escritos sobre os movimentos em dois grandes blocos, aqueles produzidos no calor dos acontecimentos ou pouco tempo depois e os produzidos alguns meses depois, quando o movimento já havia refluído (ou mudado de característica) e havia já algum, ainda que pequeno, distanciamento temporal.

Castells, que acompanha a realidade brasileira há algum tempo, se manifesta no mês seguinte aos acontecimentos (julho/13), quando na verdade ainda estavam em marcha, não escrevendo mais do que quatro páginas sobre os eventos em um posfácio de um livro sobre a chamada primavera árabe, os chamados indignados bem como os movimentos occupy. Castells capta alguns elementos essenciais de todo esse processo. Começa afirmando que "Aconteceu também no Brasil. Sem que ninguém esperasse". Ainda acrescenta ao seu lote de surpresas: "Sem líderes. Sem partidos nem sindicatos em sua organização. Sem apoio da mídia. Espontaneamente”. A maior parte desse diagnóstico é praticamente concordância geral, mas o "espontaneamente" não reconhece todos os esforços e tentativas feitas pelo MPL em momentos pretéritos. Ainda nota que os direitos humanos não estão sendo respeitados e isto ocorre fundamentalmente devido à uma classe política que estaria agindo basicamente na defesa de seus interesses. Generaliza dizendo que é um processo mundial, pois "[...] a democracia tem sido sequestrada por profissionais da política" que emitem a mensagem que "[...] a política é coisa dos políticos, não dos cidadãos”. (CASTELLS, 2013, p. 182)

O autor ainda associa os movimentos, como de fato ocorreu, à realização da Copa do Mundo de futebol que “[...] converteu-se num negócio mafioso de corrupção em grande escala” envolvendo setores privados e públicos, "[...] utilizando em boa medida fundos públicos sem controle de contas". O autor ainda busca a explicação para os movimentos no modelo de desenvolvimento do País, fazendo críticas à política de educação, saúde, ambiente, expressando que os movimentos se formaram 
de "forma confusa, raivosa e otimista", gerando uma "consciência de milhares de pessoas" que se conectavam tanto nas redes como nas ruas. Por outro lado, "[...] o mais significativo do movimento brasileiro até o momento tem sido a resposta das instituições políticas”, observando que "[...] a classe política em sua grande maioria rechaçou o movimento como demagógico e irresponsável”, sublinhando a violência como os governos de São Paulo, "tucano", e do DF, petista, reprimiram os movimentos. Em sua percepção, foi a primeira vez que a mais alta autoridade do país, a presidente, declarou que “[...] tinha a obrigação de escutar a voz das ruas" legitimando os movimentos e fazendo com que as autoridades locais anulassem os aumentos das tarifas de transporte. Realça também que a presidente “[...] prometeu uma série de medidas (até o momento, apenas promessas), relativas a um grande investimento público em educação, saúde e transporte". (CASTELLS, 2013, p. 183-184)

Aqui reside o problema, a dificuldade de análises feitas enquanto a História está sendo escrita, sem qualquer desfecho mais concreto passível de visualização, ainda que o autor diga que são apenas promessas. Ainda percebe o autor como "mais relevante" a reforma política que possa combater a corrupção e a criação de "[...] um sistema eleitoral mais representativo e fórmulas de participação cidadã que limitem a partidocracia”. Passado um ano e meio dos acontecimentos, pode-se constatar que a resposta veio apenas na forma da suspensão dos aumentos caindo as promessas no vazio, salvando-se apenas, e de forma muito criticada e passível de conflitos, o programa "mais médicos" na área de saúde. A visão favorável de Castells à presidente é estampada quando visualiza uma "[...] profunda inquietude da classe política ante a possibilidade de aliança entre um movimento social autônomo e uma Presidência democrática e democratizante”. Novamente, essa expectativa não se confirmou possivelmente porque as premissas para sua ocorrência sejam falsas. Mas o autor também toma suas cautelas ao entender que "[...] o movimento tampouco confia na presidenta" e assim, “[...] o resultado dessa inovadora interação entre a política nas ruas e a política nas instituições é, no momento em que escrevo este 
texto, julho de 2013, uma questão em aberto", abrindo o autor a possibilidade de que "[...] novamente se aborte a vontade de mudança das instituições políticas” (CASTELLS, 2013, p. 185), o que afinal aconteceu, mais uma vez.

O livro Cidades Rebeldes pode ser considerado um empreendimento ousado, pois lançado no mês seguinte aos eventos de junho/13! Os artigos que tratam do Brasil remetem, em geral, a um engajamento substanciado em quadros mais estruturais para entender o fenômeno, tais como o capitalismo, a acumulação, o papel das cidades, a exclusão. Para a encarregada de fazer a Apresentação do livro, as manifestações podem ser pensadas como "um terremoto" que veio a perturbar "[...] a ordem de um país que parece viver uma espécie de vertigem benfazeja de prosperidade e paz”. Esses movimentos fizeram “[...]emergir não uma, mas uma infinidade de agendas mal resolvidas, contradições e paradoxos. Mas, sobretudo - e isso é o mais importante -, fez renascer entre nós a utopia”. Ao encerrar a apresentação dos artigos, a autora assevera que “[...] a voz das ruas não é uníssona. Trata-se de um concerto dissonante, múltiplo, com elementos progressistas e de liberdade, mas também de conservadorismo e brutalidade, aliás, presente na própria sociedade brasileira”. (ROLNIK, 2013, p. 8, 12)

No mesmo livro, Maricato e colaboradores (2013, p. 19, 26), por sua vez, diz que quem acompanha a realidade das cidades brasileiras “[...] não estranhou as manifestações que impactaram o país”, pontuando, no entanto, que o fato dos manifestantes serem formados por jovens predominantemente de classe média “[...] exija uma explicação um pouco mais elaborada”, o que efetivamente não é feito. Em seu entender, "[...] é impossível dissociar as principais razões, objetivas e subjetivas desses protestos, da condição dessas cidades”. Em seguida, a autora discorre sobre as condições de exclusão das cidades e a deterioração das condições de vida, principalmente dos setores populares, encaixando essa discussão nos parâmetros da hegemonia neoliberal. Finaliza clamando pela reforma política como “[...] primeiro item necessário à política urbana”. 
No mesmo pacote, Carlos Vainer $(2013$, p. 36, 39) identifica que todos "[...] foram pegos de surpresa pelas manifestações de massa que mudaram a face e o cotidiano de nossas cidades em junho". Argumenta que os movimentos dominantes nas quase duas décadas anteriores eram movimentos sociais rurais, enquanto as lutas urbanas mostravam muita fragmentação e dispersão e que havia muita dificuldade de unificação dessas lutas. Mao dizia que uma fagulha pode incendiar uma pradaria, pois esta "[...] ]estava seca, pronta para incendiar-se" sendo, agora, a pradaria as nossas cidades. Para o autor, existe uma "conexão estreita entre os protestos em curso" e os "maciços investimentos" ligados à Copa de 2014 e aos Jogos Olímpicos de 2016. Vendo a questão de ponto de vista mais estrutural, associam-se a cidade e o planejamento no contexto da valorização do capital e da lógica neoliberal, na qual predomina o mercado, o que se expressa no fato de remoções forçadas para a periferia deixando a cidade livre para os mega eventos, "[...] periferias distantes, a duas, três ou quatro horas dos locais de trabalho, a custos monetários absurdos e condições de transporte precaríssimas", como também se verá na análise da RV. Assim, dado esse "[...] contexto, o surpreendente não é a explosão, mas que ela tenha tardado tanto".

Iasi (2013, p. 41-44) também vai assentar sua compreensão do fenômeno em fundações mais estruturais sobre a sociedade contemporânea, o capitalismo recorrendo à Freud, Sartre, Luckács e outros para fundamentar sua análise. Assim, as contradições urbanas são vividas pelas pessoas na “[...] forma de uma serialidade, isto é, presas em seus casulos individuais", não formando um grupo e sim “[...] um coletivo serial no qual prevalece a indiferença mútua”. A sociabilidade criada historicamente na sociedade burguesa se apresenta como "[...] realidade à qual temos de nos submeter, reprimindo nossos impulsos". Trazendo esse sintético, mas denso, referencial para o fenômeno em tela, ao perceber que houve aumento da passagem do ônibus, "[...] o indivíduo serializado pode reagir de duas formas: aceitar, porque “a vida é assim, fazer o quê?" ou reclamar, pois “[...] a vida não deveria ser assim - e pagar”. Em outras palavras, “[...] os indivíduos vivem a revolta ou buscam a adaptação no interior da serialidade”. O papel da ideologia, 
nesta construção é central, pois "Adaptado ou revoltado, o indivíduo serializado segue sua vida subsumido ao real. A ideologia é a forma da subjetividade que permite dar sentido a essa subordinação".

Além da ideologia, outra mediação é a luta, que é "mais complexa", se corporificando nos movimentos sociais, nos sindicatos, partidos de esquerda, havendo a sensação de que “[...] são sempre uma minoria os que lutam”. A essa altura, o autor chama a atenção para o fato de que, ao contrário do que alguns pensam, “[...] o problema não é somente uma questão de organização e comunicação", identificando a existência de um "[...] atual culto fetichizado dos meios", que explicaria a "[...] explosão de insatisfação popular ocorrida Brasil afora em junho de 2013 que teria sido determinada pelo uso de novos meios convocativos, com as redes sociais na internet”. (IASI, 2013, p. 44) Este presente artigo subscreve completamente esta visão, colocar a tecnologia em primeiro plano é colocar o carro na frente dos bois, é confundir meios com fins, conforme já apontou Pinho (2008). Iasi (2013, p. 44-46), evidentemente, não diminui a importância dos meios e das formas de comunicação, mas alerta que “[...] o problema é de outra natureza” constituindo-se "[...] um diálogo entre dois segmentos da classe trabalhadora que estão em momentos diferentes do processo de consciência”. Assim, quando os jovens do MPL “vão para as ruas" e tanto o Prefeito de São Paulo quanto o Governador de São Paulo recusam o corte do aumento das passagens e este último mobiliza as forças da Polícia, era de se esperar uma "volta à normalidade" havendo uma "[...] confiança na passividade imposta aos movimentos sociais” por parte do governo federal. Porém, “[...] a repressão aos jovens e à prepotência dos governantes funcionaram como catalisador das contradições que germinavam sob a aparência de que tudo corria bem em nosso país". Assim, "[...] o dique da ideologia não foi capaz de contê-la" [a vida que transbordava]. O autor ainda registra que os "[...] patéticos pactos propostos pela presidente Dilma” correspondiam a uma estratégia de que "tudo deve continuar como estava".

Ao examinar como é que os movimentos mudaram de escala quantitativa, Peschanski (2013, p. 59) faz uma importante diferenciação 
para entender os movimentos de junho/13, qual seja, esses protestos não começaram "[...] "contra” algo, mas como uma expressão coletiva "a favor" de algo", no caso a recusa encabeçada pelo MPL ao aumento de 20 centavos na passagem. Para Secco (2013, p. 72, 74, grifo do autor) as jornadas de junho pareciam "um enigma". Ao constatar o aumento brutal de manifestantes nas ruas, entende-se que, a princípio, havia “[...] a pauta popular, organizada de baixo pra cima" trazendo a questão da tarifa do transporte, ao que se somou, em seguida, uma "pauta de massa" vinda de cima para baixo, onde ocorre uma crítica aos políticos consubstanciada em um emaranhado de demandas. Secco também traz a questão das formas de comunicação para a compreensão dos movimentos. Afirma que, apesar de "[...] a maioria dos jovens manifestantes usar a internet para combinar os protestos, os temas continuam sendo produzidos pelos monopólios de comunicação". Assim, "A internet é também um espaço de interação entre indivíduos, mediada pelo mercado de consumo e vigiada pela 'inteligência dos governos'". [ênfase no original] Esta interdependência entre internet e imprensa (ou mídia em geral) ficará concreta ao se examinar o movimento Fora Sarney, adiante. Secco aponta ainda uma guinada no movimento quando, a partir do momento que a violência passou a fazer parte das manifestações, ocorreu uma “[...] queda abrupta do número de manifestantes", o que o leva a atribuir que o movimento que tinha no seu início um caráter "[...] apartidário se tornava, então, antipartidário".

Venício de Lima (2013, p. 90) também toca na questão do uso das redes para a mobilização. Sendo a maior parte dos participantes formada por jovens e estando "conectados" pelas redes e não estando representados e nem encontrando expressão através da "velha mídia", esses jovens "ainda dependem dela para alcançar visibilidade pública, isto é, para serem incluídos no espaço formador da opinião pública”. Isto se deve ao fato de que a mídia, principalmente a televisão, "[ainda] controla e detém o monopólio de “tornar as coisas públicas'”. Além de dar visibilidade, ela é indispensável para 'realimentar' o processo e permitir sua própria continuidade”, o que também será visualizado no FS. 
Uma tendência para a construção de um entendimento teórico se apoiou na citação dos movimentos anteriores mais significativos da sociedade brasileira, o Diretas-Já e o movimento dos "caras pintadas", mas ressalvando-se que eram momentos, situações e movimentos, muito diferentes dos protestos de 2013. Neste caso, emerge uma clareza que se estava frente a um novo animal político. De qualquer forma, é bom aprender algo mais estrutural com, pelo menos, os "caras pintadas" por ter em comum com o movimento mais recente o fato de ter tido uma predominância de juventude. Escrevendo anos antes das recentes manifestações de rua, José de Souza Martins (2011, p. 95, 96, 98) lembra que, no processo que pleiteava o impeachment de Collor, “[...] a população só tardiamente foi às ruas e, mesmo assim, quem o foi era notoriamente uma bem definida categoria de jovens estudantes, os chamados 'caras pintadas'”. O autor mostra que a tradição brasileira assenta-se no mecanismo da troca de favor. A relutância da população em ir às ruas para apoiar as investigações parlamentares contra Collor explica-se pelo fato de que a população “[...] não podia ver ilegalidade no que lhe era, aparentemente, legítimo. Legitimado, além do mais, pela tradição da política de troca de favores". Assim, o ir para a rua pode ser visto mais como exceção do que como regra na realidade brasileira. As manifestações de rua foram fundamentais para aprofundar as investigações, produzindo “[...] uma nova realidade política baseada numa espécie de dupla e contraditória legitimidade: a legitimidade do voto e a legitimidade da rua". É possível também identificar uma forte contradição pois, no caso da cidade da cidade de São Paulo, a população que foi às ruas pedir a cassação de Collor, ou a que não foi impedir a cassação do presidente, na eleição seguinte “[...] elegeu um político submetido a reiteradas acusações de corrupção”. Não há como negar essa afirmação, mas esta deve ser levada como uma figura de retórica, pois seria preciso identificar quem foi às ruas pedir a cassação do presidente e quem votou no suspeito candidato a prefeito, pois não são o mesmo grupo. Os que vão às ruas, no caso do pedido de impeachment de Collor podem ser vistos como uma "[...] espécie de multidão iluminista, que vislumbra o conflito entre a impessoalidade do poder e o uso 
pessoal do poder, condenando este último". Acreditamos que este diagnóstico, entendimento da questão, pode, em grande parte, ser aplicado às manifestações de 2013 .

Recorrendo ainda a Souza Martins (2013), passados seis meses do encerramento das manifestações, o autor faz uma pertinente diferenciação entre movimentos sociais e manifestações coletivas. Embora não os conceitue, parece possível inferir como movimentos sociais os movimentos tradicionais, enquanto que manifestações coletivas são aquelas que "[...] dão voz e visibilidade à maioria silenciosa". Complementa o autor que, no regime militar, emergiu um sujeito político com "[...] demandas tópicas que incluíam reformas sociais", enquanto que no "decênio do petismo" germina, em silêncio, um outro sujeito político, de caráter "claramente antipartidário" que reflete o "descrédito da política”. Ao identificar que sendo manifestações de classe média, a educação já não entra na pauta (ver abaixo), “[...] mas se motiva na educação para o protesto”. O autor faz uma importante diferenciação observável nos protestos, “[...] o protagonismo do manifestante contra o do militante”. É oportuno lembrar que houve uma recusa à participação de partidos com suas bandeiras, indicando não só recusa por parte dos manifestantes das estruturas partidárias como também a percepção da captura instrumental dos movimentos por parte dos partidos políticos, coisa que os manifestantes queriam evitar.

Michael Löwy (2013), que também tem sido um importante observador da cena política brasileira, em pronunciamento ao final de 2013, portanto já um tanto distante do calor dos acontecimentos, registra que, por morar em Paris, não acompanhou as “[...] jornadas de junho in loco”. Em sua primeira vinda pós-manifestações iniciais, sentiu ainda "uma agitação no ar" que eram novos capítulos "desse longo junho". Para ele, os 20 centavos foram "a faísca” e, como "a pólvora estava seca”, aconteceu que "[...] as chamas se alastraram rapidamente". Interessante notar que o autor observa que "[...] o movimento explodiu quando as pessoas deixaram de ficar só no Twitter e no Facebook, saíram do sofá e foram à rua, essa coisa antiga”. Aqui cabe um parêntesis. Como este artigo persegue também o objetivo de confrontar experiên- 
cias nas quais essas tecnologias digitais não existiam e as atuais com a disponibilidade de uso intenso dessas tecnologias, então cabe perguntar onde ficavam antes as pessoas que tinham um engajamento político já que não existiam essas tecnologias. Pode parecer uma questão prosaica, mas, na forma colocada, parece que existem dois momentos de mobilização política: no sofá, no Twitter e no "Face" e, depois, na rua. Obviamente, antes da internet, as pessoas se mobilizavam, discutiam, debatiam e iam para as ruas.

Voltando à Löwy (2013), a ida às ruas provocou um "terremoto" que não era só pelos 20 centavos, isto, apenas simbolizava "[...] um sentimento profundo de injustiça social, de insatisfação com os rumos administrativos das cidades, de indignação com a ordem das coisas no mundo". Em seu entender, a luta pelo passe livre mexe em questões estruturais que "[...] o transporte público deve ser público e gratuito, isto é, não deve ser um negócio". Assim, a luta pelo transporte gratuito carrega uma proposta de que outra realidade é possível, em seu olhar. Observa ainda o autor que "[...] à repressão brutal da polícia” em São Paulo e Rio, aos estudantes juntaram-se outros setores da sociedade que também "foram às ruas". O autor ainda registra que outras questões começaram a "pipocar", "[...] muito justas, mas diversas: o dinheiro esbanjado nos estádios da Copa, a precariedade nos campos de saúde e da educação, os políticos corruptos, e assim por diante". Sintetiza assim o autor suas observações que as jornadas produziram “[...] duas ideias emancipadoras. Primeiro, a importância do serviço público para a sociedade. Segundo, se quiser seus direitos, o povo precisa ir às ruas". Detendo-nos neste último, parece ser possível extrair que Twitter e Face não fazem a revolução, ao que tudo indica o teatro de operações ainda é a rua, o locus concreto e não virtual.

Marco Aurélio Nogueira (2013, p. 19-20) se manifesta na introdução de um livro seu sobre os movimentos em setembro de 2013, ou seja, bem pouco tempo depois dos protestos de junho e seus desdobramentos. Em seu entender, as razões da "efervescência" das massas estão inscritas "[...] na realidade do capitalismo globalizado, na história nacional e na conjuntura política”. Os protestos se voltaram 
contra "[...] as deficiências do sistema de prestação de serviços públicos”. A briga não se deu pelos vinte centavos, “[...] mas por muito mais, talvez por quase tudo". A luta foi estruturada ignorando "[...] parlamentares, sindicatos e partidos políticos" ocorrendo de "modo espontâneo e improvisado", dirigia-se com clareza "[...] contra o governo representativo tal qual estruturado no Brasil” se voltando contra "[...] todos os governos: contra o sistema político, seus atores, seus procedimentos e sua cultura”. Os protestos questionaram o sistema que se expressa “[...] na conduta dos políticos, dos partidos e dos governantes", que leva ao "[...] enriquecimento de certos atores e à disseminação de ilícitos de todo tipo".

A crise que se apresenta "[...] é mais que crise política: é crise de um sistema perverso", crise esta que "não surgiu de repente", mas foi se aprofundando tanto no plano federal como nos Estados (para não mencionar os municípios) que são marcados por “[...] falhas graves e desempenho medíocre” onde a corrupção "cresceu ininterruptamente". Esse sistema aprofundou o fosso entre "[...] a miséria de boa parte da população e os gastos desnecessários, o desperdício e o uso suntuoso de recursos públicos pela elite política e administrativa" dos três poderes. (NOGUEIRA, 2013, p. 21)

No entender de Nogueira (2013, p. 22-23), essa "perversão sistêmica” acentuou-se durante o período em que o PT assume o poder federal. Lembra o autor que este partido marcou a história política brasileira "em sentido positivo" ajudando a mudar "a face social do país", fazendo a inclusão social. Porém, enquanto "ator político" acabou se comprometendo, "sujou as mãos", acabou organizando "[...] coalizões à direita e a operar o velho jogo político que antes condenava” bem como se distanciou da sociedade civil. Ainda que tenha encertado políticas de combate à miséria, "[...] combinaram assistencialismo paternalista e direitos de cidadania”, o que veio a produzir "[...] efeitos sociais importantes, mas que não modificou a estrutura do país”. Nos passos de Gramsci, ao invés de construir um "[...] projeto de hegemonia, organizaram um projeto de poder”. Como os governos petistas reproduziram "[...] as bases do clientelismo, do patrimonialismo e da 
corrupção" este fato atuou como "combustível adicional de frustração e indignação" que acabou por aumentar com a percepção dos “[...] gastos exorbitantes e sem critérios claros, o enriquecimento dos dirigentes políticos”, entre outros aspectos.

Como os partidos políticos “[...] pesam pouco na organização de consensos sociais”, Nogueira (2013, p. 23) percebe que tem “[...] uma revolução em marcha, mas ela não é nem a dos trabalhadores e nem a das classes médias". Entende tratar-se de “[...] uma revolução sem revolução, a sociedade ultrapassando o sistema político e pondo em xeque o que está instituído". O que o autor constrói pode parecer um paradoxo, mas como vários autores pontuaram que era de difícil compreensão o que havia acontecido, parece que um paradoxo, ou um aparente paradoxo pode servir para entender os acontecimentos. É essa também a posição do autor em tela ao afirmar que tudo emergiu “[...] de uma só vez. Daí, talvez, a dificuldade para que se compreenda o que se passou. É que o país ficara diferente e não se havia dado conta disso".

Ainda outro ponto merece destaque na formulação do autor quando aponta que os eventos ocorreram com "[...] tendências 'niilistas' pré-políticas”, advertindo não fazer sentido "romantizar os protestos, vê-los como sendo o anúncio de uma democracia revitalizada e ignorar que eles foram uma 'terra de ninguém', aberta ao protagonismo genérico de muitos grupos e indivíduos". Refreia ainda os espíritos mais otimistas ao afirmar que "As ruas brasileiras têm baixo poder de agenda”, mas “[...] seu efeito positivo não pode ser desprezado. A vida política não será mais a mesma, ainda que demore para mudar”. (NOGUEIRA, 2013, p. 24) O autor põe, assim, o freio naqueles que esperavam mudanças repentinas e automáticas, falando até em revolução.

André Singer (2013, p. 23, grifo do autor), por sua vez, entende que em junho/13 houve "um tremor de terra", mas longe de "um terremoto", dado que "[...] relações de classe e propriedade não estiveram diretamente no centro das manifestações". Evidentemente, isto não fazia parte do menu, e dificilmente tem pertinência na realidade das reações da sociedade brasileira. Mesmo escrevendo alguns (poucos) 
meses depois do evento estabelece que "[...] nunca restou nítido o que estava acontecendo".

Singer (2013, p. 23-24) enfatiza que não dá para imaginar, "seriamente", estar acontecendo “[...] uma tentativa de revolução”. Parece que se valoriza muito a ideia de que qualquer movimentação da sociedade seja uma revolução. Os eventos cumpriram três fases: na primeira, uma “[...] fração pequena, embora valorosa, da classe média” realizou as mobilizações em São Paulo com objetivo da redução das passagens do transporte público. As manifestações foram engrossando o número de manifestantes até que a violência policial se manifestou. Na segunda etapa dos movimentos, houve uma incorporação de maior número de manifestantes quando "[...] outras frações da sociedade entram espontaneamente em cena", ao mesmo tempo em que ficam "vagas as suas demandas". As demandas são embasadas em críticas à falta de educação, saúde, moradia e contra os gastos com a Copa das Confederações, contra a corrupção, bem como à classe política e aos partidos, registra Singer.

Quando a Copa das Confederações começa, São Paulo “[...] perde centralidade, com o protagonismo passando as praças onde haveria jogos", sendo que no Rio, as manifestações “[...] adquirem certo sabor de sublevação popular". Na terceira etapa, que vai do dia 21 de junho até o final do mês, “[...] o movimento se fragmenta em mobilizações parciais com objetivos específicos" (SINGER, 2013, p. 24, 26) e pontuais. Refletindo sobre os acontecimentos, Singer (2013. p. 27-28) observa que o tema "[...] deverá ser alvo ainda de muita pesquisa" e assim estabelece algumas hipóteses, construídas "quase no calor da hora", detendo-se em dois aspectos: "[...] a composição social e as ideologias que se cruzaram nas ruas". Quanto ao primeiro aspecto, defende que a composição social continha tanto uma "classe média tradicional" junto ao "novo proletariado", formado por trabalhadores jovens com carteira assinada, mas em situação de "[...] baixa remuneração, alta rotatividade e más condições de trabalho”. A composição era predominantemente de jovens somados a jovens adultos e também com alta escolaridade. Os dados também mostram que se detectava nas ruas “[...] uma míni- 
ma parcela de baixa escolaridade, denotando a virtual ausência da base da pirâmide social brasileira nas manifestações".

Mais que isso, os dados revelam uma grande participação de universitários, atingindo, no caso de São Paulo, quase 80\% do contingente dos manifestantes. Quando se acrescenta os estudantes de nível médio, as manifestações teriam assumido "[...] fortes tintas de classe média tradicional”. Porém, ao se inserir os dados de renda, verificase que metade dos manifestantes estavam no grupo de baixa renda (menos que 5 salários mínimos), indicando que cerca de metade dos manifestantes pertenciam à “[...] metade de baixo da estratificação por ocupações" revelando que "[...] o novo proletariado ou precariado, conforme sugerido por alguns autores, foi para as ruas”. (SINGER, 2013, p. 29, 31)

Ao se fundamentar em todos os dados de pesquisa disponíveis, Singer sugere que "a melhor imagem" para retratar a composição social dos manifestantes, seja a de "[...] dois blocos relativamente equivalentes, formados por jovens e jovens adultos de classe média e outro por pessoas da mesma faixa etária, mas pertencentes à metade inferior da estrutura social brasileira, sendo estes com menos escolaridade média”. (SINGER, 2013, p. 31)

É oportuno notar que a palavra é usada no plural, manifestações, foram várias. E entendemos que à medida que as novas manifestações iam ocorrendo ia também atraindo outros segmentos sociais. Como as pesquisas não aconteceram nas primeiras manifestações, até porque não se sabia o vulto que iam tomar, fica-se mais com aquelas acontecidas após as primeiras rodadas. Mas, é certo, que tendo sido as manifestações convocadas pelo MPL, a composição inicial seria fundamentalmente de jovens e estudantes. Ao se engrossar a fileira dos manifestantes nas rodadas subsequentes, Singer (2013, p. 34) defende que "[...] o que havia sido um movimento da nova esquerda passou a ser um arco-íris, em que ficaram juntos desde a extrema-esquerda até a extrema-direita", predominando cartazes contra a corrupção e a cobrança de impostos e, ainda, críticas aos gastos com a Copa de 2014 e as Olimpíadas de 2016. 
Em suma, Singer (2013, p. 36) entende que, talvez, de uma maneira um tanto simplificada ou reducionista, "[...] a direita trouxe para a segunda fase das manifestações o problema da corrupção e a esquerda, o das iníquas condições da vida urbana”, mas registrando que “[...] o realmente novo foi a atuação do centro, o qual teve a vantagem de poder assumir uma e outra bandeira, bradando simultaneamente contra os gastos públicos privatizados pelo capital e contra a corrupção”.

Vale ainda trazer o registro feito por André Singer (2013, p. 33) sobre o perfil do MPL, quando de uma entrevista dada ao Programa Roda Viva da TV Cultura-SP por dois representantes do MPL apenas expressaram o “[...] que se poderia chamar de 'mandato imperativo': só disseram o que a 'assembleia' os autorizava a dizer”, recusando-se a falar de suas vidas pessoais, “[...] abstendo-se de aproveitar a oportunidade para projetar-se como liderança individual, pronta para ser absorvida e tragada pelo star system", ou seja, afastaram-se da política tradicional de exploração do papel das lideranças.

Uma das contribuições de Maria da Glória Gohn (2013) se dá cerca de um mês depois dos eventos entendidos como expressando "[...] estados de indignação face à conjuntura política nacional”. A autora formula a questão fundamental: “[...] porque uma grande massa da população aderiu aos protestos"? Em seu entender, os "prováveis motivos", indo além da questão da tarifa, estão localizados, nos “[...] gastos altíssimos com estádios da Copa, megaeventos e uso do dinheiro público em eventos promocionais, a má qualidade dos serviços públicos, especialmente transportes, educação e saúde" e, ainda, entre outros, "inflação, denúncias de corrupção" ao lado de "[...] sentimento de impunidade, sistema político arcaico, criminalização dos movimentos sociais" e ainda outros. Assim, a ideia de um “[...] Brasil tudo azul, para o senso comum de seu povo em geral, era uma construção irreal”. Observa ainda a autora que com a violência empregada pela Política, “[...] este 'povo' saiu às ruas e mais uma vez demonstrou que a cordialidade do brasileiro tem limites".

Buscando caracterizar os movimentos, os vê como "[...] uma nova forma de movimento social composta predominantemente por jovens, 
escolarizados, predominância de camadas médias, conectados por e em redes digitais, organizados horizontalmente e de forma autônoma". Essas características fazem com que se tornem "[...] críticos das formas tradicionais da política”, “[...] especialmente os partidos e os sindicatos". O movimento, convocado pelas redes sociais, "[...] acontece 'em se fazendo' e não via grandes planos de organizações com coordenações verticalizadas", tornando-se “[...] laboratórios de experimentações de novas formas de operar a política”. (GOHN, 2013)

Em termos da formação dos manifestantes, entende a autora que “[...] poucos têm trajetórias de militância e experiências associativas anteriores. Participam de coletivos, mas preservam valores individualizantes, que é diferente de individualista". Também localiza nestes “[...] uma profunda falta de confiança em toda forma de política e categoria de políticos", desejando "[...] outro país onde a ética e política andem juntas". Como não se sentem representados pelo sistema político existente, “[...] detecta-se também uma crise de representação social desses grupos e uma crise de legitimidade das instituições públicas”. (GOHN, 2013)

Do ponto de vista da ideologia que move esses manifestantes, Gohn (2013) entende que "[...] não há hegemonia de apenas uma ideologia”, sendo as fontes a esquerda, o anarquismo e o socialismo libertário, a autogestão, como também “[...] um novo humanismo na ação de alguns, expresso em visões holísticas e comunitárias, que critica a sociedade de consumo, o egoísmo, a violência cotidiana".

A autora ainda identifica que uma das questões "profundas" que está na agenda dessas manifestações se refere à "discussão da democracia”, elaborando que enquanto a “[...] democracia representativa está em crise" e a democracia direta é viável apenas em pequenos grupos, emerge a democracia deliberativa, mas que onde tem ocorrido "[...] padece de arranjos clientelísticos". Assim, em seu entender, as manifestações expressam a busca por "[...] novas formas de organização política, nos marcos da democracia”, mas que ainda não está clara. A autora ainda relembra que "[...] a luta pelos transportes públicos é histórica" (GOHN, 2013) relembrando a Revolta do Vintém em 1880 no Rio de 
Janeiro, a ser considerada na sequencia deste artigo, bem como lutas pelo transporte no final dos anos 1970 em várias cidades brasileiras.

Fazendo uma síntese apertada dessas contribuições teóricas, talvez possa se identificar dois grupos bem definidos. O primeiro situa as manifestações em críticas ao capitalismo, ao neoliberalismo, à ordem mundial hegemônica, ainda que, vez ou outra, salpicando com alguns elementos da conjuntura do País. O segundo grupo, ainda que também faça referências a um quadro mais geral, e até internacional, situa a origem e motivação das manifestações mais em problemas da estrutura do País, da trajetória histórica do Brasil, e com ênfase na conjuntura, principalmente a gerada a partir dos governos do PT no plano federal com opções de política e de políticas públicas feitas pelos ocupantes do poder federal.

\section{OS PROTESTOS DE JUNHO/13}

Muito do que foram as manifestações já foi apresentado acima, mas, acredita-se, que um passo necessário para entender estas manifestações coletivas demanda caracterizar seus participantes. Para tanto, recorremos à Pesquisa IBOPE realizada em 20 de junho de 2013 em oito capitais com 2002 entrevistados, que encontrou os seguintes resultados pesquisa realizada quando os movimentos já tinham sido encorpados, ou seja, não capta as primeiras manifestações:

- Idade: 14 a 24 anos: $43 \%$.

- Escolaridade: Superior: 43\%; até o colegial incompleto: $8 \%$

- Trabalha: sim,: 76\%; Estuda atualmente: $52 \%$.

- Renda familiar: até 2 Salários Mínimos (SM): 15\%; Mais de 5 SM: $49 \%$

Essa bateria de dados permite observar que as manifestações contaram fundamentalmente com um público jovem, com formação educacional elevada, formada em grande parte por estudantes, mas também trabalhadores. E o perfil de renda para os padrões brasileiros é relativamente alto. 
- Razões para participar: transporte público: 37,6\%; ambiente político: 29,9\%; saúde: 12,1\%; contra a PEC37: 5,5\%; educação: $5,3 \%$, Gastos com as copas: $4,5 \%$, Luta contra o capitalismo: 0,1\%; Aumento de salários: 0,2\%

Essa bateria de dados, por sua vez, mostra que a motivação básica para participar reside na questão do aumento da passagem do transporte público. Mas não é nada desprezível que a insatisfação com o ambiente político venha logo em segundo lugar. Ao se somar essas duas queixas, atinge-se um total de $67,5 \%$, o que mostra que ao lado de uma motivação bem focada alinha-se uma de caráter mais difuso com o quadro político do País. Nota-se também que a insatisfação com serviços públicos consubstanciados em Saúde e Educação, responsabilidade do Estado, atinge 17,4\%. Ainda vale mencionar a presença no pacote de insatisfações os gastos com a Copa e uma menção a PEC 37. Cabe, ainda, notar que as demais são irrelevantes do ponto de vista quantitativo, mas eram normalmente ponto de agenda obrigatório dos movimentos mais tradicionais, expresso pela luta por salários e contra o capitalismo. Tudo isso leva a confirmar que se estava frente a um novo tipo de movimento bem como de participantes, como já registrado várias vezes.

- Participações anteriores: já: 54\%; $1^{\mathrm{a}}$ vez: $46 \%$

- Como soube: face 62\%; internet $29 \%$; amigos e colegas $28 \%$; TV $14 \%$; jornais $4 \%$, rádio $4 \%$, base do movimento: $3 \%$

Essa bateria de dados mostra que uma parte significativa dos manifestantes, praticamente a metade, era neófito em termos de participação em eventos deste tipo. Por outro lado, a forma de conhecimento da realização das manifestações, predominando o Facebook e a internet, convergem com o dado da participação predominante de jovens.

- Se sente representado por algum político: Não 83\%; por algum partido: Não $89 \%$.

Esse dado mostra claramente o que já foi revelado acima sobre a crítica ao ambiente político, ao expressar que partidos e políticos elei- 
tos não representam majoritariamente os cidadãos, mostrando a falência do sistema político.

Uma conclusão possível a ser extraída é que foi um movimento de jovens, uma boa parte de estudantes, muitos já com nível superior, um movimento fundamentalmente de classe média, mas não só, e de caráter apartidário. Vale reforçar que sendo esta pesquisa realizada no dia 20 de junho, após manifestações anteriores, esta última e as seguintes já devem ter capturado um público que ia além do protesto contra o aumento das passagens.

\section{MOVIMENTO FORA SARNEY}

Nesta seção, vamos examinar o Movimento Fora Sarney (FS), levado a cabo em várias capitais no Brasil ao longo de 2009, detendo-nos no caso de Salvador, escolhido por facilidade de acesso e possibilidade de acompanhamento constante.

Antes de proceder a análise do estudo de caso, vale notar que a expressão \#forasarney foi usada pela primeira vez em 17 de junho de 2009 pelo humorista e apresentador de TV Rafinha Bastos. Sua motivação foi a série de denúncias de irregularidades no Senado brasileiro alavancada pelos atos secretos, sendo um dos maiores beneficiados por eles o presidente da Casa, José Sarney (PMDB-AP). Em 29 de junho, coordenado com um evento contra Sarney na capital de seu estado de origem (São Luís, no Maranhão), o volume de mensagens que continham a hashtag \#forasarney superou a marca de 10 mil mensagens por hora, de modo que a página chegou a ficar fora do ar pelo excesso de mensagens. Em 30 de junho e $1^{\circ}$ de julho, foram marcadas manifestações públicas em várias grandes cidades brasileiras que, apesar do apoio de celebridades e de partidos de esquerda, reuniram poucas pessoas e, em Florianópolis e Porto Alegre, nenhuma. (FORASARNEI, 2009) Os protestos realizados em 01/julho/2009 em São Paulo reuniram 70 pessoas na Avenida Paulista, em Campinas apenas 10 pessoas em frente à prefeitura, no Rio de Janeiro 30 manifestantes se reuniram frente à Câmara Municipal, no Amapá, domicilio eleitoral do senador, um ato convocado por partidos de esquerda. O que se 
pode perceber é que o forte ativismo nas redes não vazou para as ruas que teve um número pífio de participantes nas manifestações, sendo oportuno mencionar que o título da matéria do jornal era exatamente "Protestos organizados por meio do Twitter falham no mundo real", indicando um profundo gap entre a participação nas redes e aquela no mundo real, nas ruas.

Além dessa característica, o movimento não conseguiu deslanchar nas capitais brasileiras, esgotando-se assim que as denúncias contra o senador José Sarney foram arquivadas pelo Senado. Em Salvador, contemplado em profundidade neste artigo, talvez uma das capitais onde o movimento tenha tido uma duração maior, aconteceu o mesmo, ainda que o movimento tenha se mantido na rede por alguns meses mais após o encerramento das manifestações de rua. A esse respeito vale dizer que o episódio que conseguiu maior adesão, o número de participantes chegou, segundo estimativas, a 150, um número certamente baixo para conseguir resultados mais expressivos. O principal jornal da Bahia noticiava em breve nota que Salvador aderia ao "Fora Sarney" quando cerca de 90 estudantes percorreram a Av. Garibaldi em protesto pela renúncia da presidência do Senado, do senador José Sarney (A TARDE, 16/08/2009)

No contexto deste artigo, dois aspectos do movimento despertam interesse para pesquisa: 1) já fez uso de tecnologias de informação, notadamente o Orkut, que tinha uma posição hegemônica naquela época no Brasil; 2) tinha um objetivo, um foco bem claro, o combate à corrupção e um engajamento no sentido de remover o senador José Sarney da política, através da cassação de seu mandato. O FS tinha, como vemos, um objetivo bem ambicioso qual seja, de mover um político tradicional, um oligarca onipresente, com mais de cinco décadas na política brasileira sobre o qual pairavam sérias suspeitas de envolvimento em corrupção. A estruturação do movimento e da luta indicarão que o FS apresentava algumas características similares aos movimentos de 2013, mas também outros aspectos que diferenciavam os dois movimentos. 
Podemos arrolar as seguintes características do FS em sua versão soteropolitana. O FS foi criado em 04 de agosto de 2009, em Salvador, no Orkut, em uma comunidade aberta para não membros. A descrição declarava ser uma "comunidade desenvolvida para expressar a indignação dos baianos ante a situação política atual, especialmente no que tange o senador José Sarney”. (PINHO et al., 2010) Em primeiro lugar, o movimento foi basicamente constituído por jovens estudantes do segundo grau e, ao que tudo indica, de escolas particulares, pertencentes a camadas de classe média e de classe média alta. Chama atenção o fato de, praticamente, não participarem estudantes universitários, o que já incita ao seguinte questionamento. Por um lado, estariam os universitários distanciados da política? Por outro lado, esta nova "geração" de estudantes do segundo grau teria despertado para a política e para uma luta contra a corrupção, e ainda mais sendo estudantes de um extrato social mais elevado? O artigo não dará respostas a todas essas questões, diga-se de antemão, pois não foi feita nenhuma pesquisa direta. Conforme já mencionado nesta introdução, um aspecto diferenciador entre movimentos seria a sua localização geográfica, o lócus onde se deu. Este, pela característica mostrada da inserção social de seus membros, foi, evidentemente, um movimento que aconteceu na região central de Salvador, ou seja, não foi um movimento ocorrido na periferia.

A metodologia de pesquisa ficou assentada no acompanhamento da comunidade do movimento FS no Orkut, já que, conforme dito acima, o movimento usou intensivamente a comunicação digital. Assim, a partir das mensagens dos participantes sobre as estratégias de luta e os conflitos resultantes de posições diferenciadas entre os membros do movimento, Pinho e colaboradores (2010) extraíram os seguintes elementos:

Galera gostaria de saber quem está organizando o movimento? Por exemplo, depois da [Avenida] Garibaldi, existe a intenção de nos deslocarmos para algum lugar? Vamos andar no meio da rua para parar o trânsito? Abraços a todos, espero encontrar todos sábado. (14/08/2009) 
Andar no meio da rua, só funciona com auxilio da polícia ou da reguladora de trânsito. A organização do Movimento FORA Sarney Bahia, em termos de net, está nas mãos do perfil "FORA Sarney Bahia", mas nada monopolizado, pq estamos todos com o mesmo intuito. Basta mandar um e-mail para forasarneybahia@ hotmail.com, ou deixar scrap no perfil (adicionem, quanto mais gente no perfil e a comentar, melhor.) que a galera publica as ideias na comu. Obs.: A comunidade é para compartilharmos nossas ideias a respeito do MOVIMENTO, que não será somente marcado por passeatas, faremos, todos juntos, muito barulho através da net. Já se está preparando algo para logo em seguida da caminhada. Manifestem-se e sugestionem. Grande abraço. (14/08/2009)

Agora a semente foi plantada. Esse foi o começo de uma revolta que não vai mais parar! Nos indignaremos e sairemos nas ruas até que a justiça seja feita no nosso país! Até que, não só o Sarney saia, mas também toda essa bandalheira do senado... todos esses corruptos que ficam aí sugando nosso dinheiro na surdina, que nem um bando de sanguessugas! Chega de sujeira moral, chega de fisiologismo! Fora Sarney e toda a quadrinha do senado! (15/08/2009)

A análise empreendida constatou um baixo índice de debate político em comparação com as postagens que tratavam dos aspectos operacionais das manifestações e do movimento. (PINHO et al., 2010) Os organizadores do site se empenhavam em não acalentar o debate político, tentando manter a unidade do movimento em torno dos propósitos de protesto consensuados pelo grupo sentindo o risco de que se o debate fosse aberto, o movimento se esgarçaria.

Este depoimento recolhido da lista ilustra bem o que está sendo dito:

Cara, eu não quero criar conflito, mas eu não concordo com você e da forma como você coloca suas críticas, apesar de concordar com algumas de suas ideias. Mas acho que você as expõem de forma ofensiva. Eu, apesar de fazer críticas ao movimento, faço parte dele e nunca me oponho ao seu crescimento. (11/09/2009)

Outra constatação foi a elevada concentração de postagens por um pequeno número de autores, dado que apenas $5 \%$ dos participantes 
foram responsáveis por criar $76 \%$ dos tópicos. Esta situação nos leva a questionar a recorrência comum às tecnologias como tábua de salvação para a política. O fato de ter a tecnologia não quer dizer que vai se operar uma mágica em que todos ou muitos participarão, emitirão opinião só porque existe a tecnologia. (PINHO, 2008) Isto posto, percebe-se que mesmo nos casos onde são poucos os que "falam" e muitos os que ouvem, em benefício da dúvida, pode-se pensar que isto indica que muitos entram na comunidade virtual talvez apenas para olhar, “ouvir”. Assim, vale sublinhar que não existe qualquer automatismo entre estar em uma lista, uma comunidade e ter uma participação ativa, o que relativiza bem o escopo das redes digitais, ao não se constatar a disseminação de uma atividade política voraz entre todos os participantes da lista.

Ao se analisar os debates no meio digital entre os participantes do movimento, constata-se uma baixa incidência de referências a partidos e políticos, sendo as energias mais direcionadas para combinar estratégias de atuação nas manifestações de rua, havendo uma "[...] forte tendência a abrandar e evitar conflitos e discussões sobre divergências entre os membros do grupo" (PINHO et al., 2010), conforme já observado. Parece possível detectar que como os participantes eram neófitos em política e em manifestações públicas, mas, por outro lado, como havia uma ligação entre eles (o repúdio ao que o senador Sarney representava), os participantes preferiram manter a convergência em torno desse ponto do que abrir um debate que pudesse fissurar o grupo ao expor as diferenças políticas entre seus participantes.

Assim, o grupo desloca suas energias fundamentalmente para combinar as estratégias das manifestações, principalmente seus aspectos operacionais, tais como, "[...] local de concentração, percurso, adoção de palavras de ordem e cânticos, confecção de cartazes e panfletos, entre outros". (PINHO et al., 2010) Um grande número de mensagens é trocado para combinar todos esses pontos. As passeatas são tratadas como eventos e adquirem caráter de espetáculo.

As mensagens abaixo expressam essa postura. 
eu acho que se queremos visibilidade deveríamos para o trânsito. Não vai adiantar nada se andarmos no passeio e a mídia não divulgar. Acho que isso pode ser pensando na hora, a depender do número de pessoas na hora. (15/08/2009)

Foi ótimo. Atingiu uma boa parte de gente que precisava dar esse apoio que foi dado. O que eu sugiro para a próxima: Avenidas como a Tancredo Neves por ser a avenida mais movimentada em área comercial de Salvador E, claro, não podemos esquecer o Campo Grande. Esse é o início de uma era política se assim desejarmos. Quem fotografou e filmou, vamos organizar um Flick e um Youtube do movimento vendo que a mídia tratou com certo desinteresse essa manifestação popular. Abraço a todos. (15/08/2009)

Bem... Como é sempre bom ter um posicionamento sobre as coisas, aqui vai o meu: achei bem feito. Bem organizado, para nós que somos "os estudantes alienados do século XXI". Não achei que a quantidade foi pouca como o jornalistazinho de merda ficou falando. Se fossem duas pessoas, até uma pessoa só, já era digno de respeito, já seria uma manifestação por seus ideais. Muitos dizem que não vai dar em nada... Pois que não dê. O movimento em si, valeu a pena. Fizemos nossa parte. O meu objetivo era que as pessoas vissem, vissem que em Salvador também tem gente como eles, que não gosta da situação. Que cada garoto da minha idade dentro daqueles carros sentisse vontade de se juntar a nós. Não era que ninguém saísse machucado, que ninguém se ferisse ou algo do tipo, e ainda bem, não foi assim. Vamos pra frente, mostrar que chega de hipocrisia, de gentinha que veste a camisa do Brasil no carnaval e na Copa. Porque eu tenho orgulho do meu país o ano todo, e terei ainda mais se me movimentar para fazê-lo melhorar no que não concordo. Parabéns, gente. Pra todos nós e para todos que participaram do movimento de alguma forma. (15/08/2009)

Galera, gostaria de saber quem está organizando o movimento? Por exemplo, depois da [Avenida] Garibaldi, existe a intenção de nos deslocarmos para algum lugar? Vamos andar no meio da rua para parar o trânsito? Abraços a todos, espero encontrar todos no sábado. (14/08/2009) 
Andar no meio da rua, só funciona com auxilio da polícia ou da reguladora de trânsito. A organização do Movimento FORA Sarney Bahia, em termos de net, está nas mãos do perfil "FORA Sarney Bahia", mas nada monopolizado, porque estamos todos com o mesmo intuito. Basta mandar um e-mail para forasarneybahia@ hotmail.com, ou deixar scrap no perfil (adicionem, quanto mais gente no perfil e na comu, melhor.) que a galera publica as ideias na comu. Obs.: A comunidade é para compartilharmos nossas ideias a respeito do MOVIMENTO, que não será somente marcado por passeatas, faremos, todos juntos, muito barulho através da net. Já se está preparando algo para logo em seguida da caminhada. Manifestem-se e sugestionem. Grande abraço. (14/08/2009)

Agora a semente foi plantada. Esse foi o começo de uma revolta que não vai mais parar! Nos indignaremos e sairemos nas ruas até que a justiça seja feita no nosso país! Até que, não só o Sarney saia, mas também toda essa bandalheira do senado... Todos esses corruptos que ficam aí sugando nosso dinheiro na surdina, que nem um bando de sanguessugas. Chega de sujeira moral, chega de fisiologismo! Fora Sarney e toda a quadrinha do senado! (15/08/2009)

Nessas mensagens, podemos perceber a estratégia dos manifestantes buscando fazer as manifestações em áreas, avenidas movimentadas da cidade, pois o movimento só seria notado se parassem o trânsito. A esse respeito, vale observar que as manifestações ocorreram em dias de fins de semana, e que, assim, os impactos no trânsito são muito menores. Pode-se perceber o entusiasmo dos participantes com os resultados alcançados, observando-se um voluntarismo no sentido de acreditar que os objetivos serão alcançados, ou seja, a cassação de Sarney. É notória também uma crítica à mídia, que não teria dado a devida cobertura ao evento, ou minimizando a importância do mesmo em termos quantitativos de participantes. Percebe-se também que eles sentem que estão dando um exemplo de participação política e é feita certa crítica àqueles que seriam acomodados, ou seja, que só seriam patriotas na hora da Copa e do carnaval. Percebe-se também o cuidado 
em evitar a violência, fenômeno que aconteceria nos movimentos de junho/13, mas, ao que tudo indica, causados pelos Black blocs e não pelos manifestantes.

Assim que uma passeata termina, Pinho e colaboradores (2010) observam que ocorre "[...] uma intensa troca de mensagens em que se congratulam entusiasmadamente pelo sucesso da ação" e já começam os preparativos para a próxima. Os participantes também não deixam de registrar "[...] a repercussão do ato na mídia, normalmente considerada decepcionante". Isso gera uma ambiguidade em relação à mídia tradicional, pois, ao mesmo tempo que a criticam, sentem que dependem dela ao entender que se a manifestação não é noticiada pela mídia, é como se não tivesse existido.

Podemos tirar desses elementos algumas percepções. Mesmo que tenha sido há poucos anos atrás (2009), não havia ainda a intensa troca de mensagens que ocorre no presente através da internet, principalmente com as mídias sociais (Facebook, Twitter). Por outro lado, o objeto das manifestações não motivou a mídia a cobrir os eventos. Por paradoxal que seja, o movimento atraiu mais atenção do Correio da Bahia do que de outros jornais, sendo que este jornal é da família de Antônio Carlos Magalhães, que tinha uma convergência política e ideológica forte com Sarney. Assim, o jornal da família de ACM poderia não ter interesse em divulgar o evento.

Quanto ao papel da mídia, segue mais um depoimento recolhido na comunidade digital.

A TV Bahia nem falou direito da passeata. É por isso que eu a odeio. (15/08/2009)

O que transpira nos debates da comunidade nos leva a perceber que se constrói uma relação com a mídia que é “[...] ambígua, conflituosa - ao mesmo tempo que alguns membros afirmam 'odiar' a mídia, demonstram forte ressentimento diante do pouco destaque dado pelos meios de comunicação às manifestações”. Parece, assim, possível identificar que "[...] estão presos a um círculo vicioso em que o movimento depende de visibilidade na mídia para crescer, mas não consegue crescer porque não consegue visibilidade da mídia”. Assim, 
quando o movimento foi divulgado pelo Jornal da Record com direito a entrevista, o fato é saudado com a afirmação de que "fizemos a diferença”. (PINHO et al., 2010) Por outro lado, quando a mídia deixa de dar destaque, não ao movimento, mas a tudo que cerca o caso José Sarney, isso abala profundamente o movimento.

Outra característica possível de observar é que os debates na comunidade exalam uma visão profundamente negativa da política e dos políticos, em que tudo que se relaciona a isso é visto de forma "[...] extremamente pejorativa, entendidos como sinônimos de corrupção”, sendo a filiação de algum participante a um partido um acontecimento visto como "acusação, ofensa". O grupo recebe com descrédito as menções referentes à filiação partidária, entendendo que os líderes políticos são identificados com "[...] a busca individual por notoriedade, visibilidade". Ao mesmo tempo, demonstram preocupação em virarem "massa de manobra" de pessoas ligadas a partidos. Desta forma, procuram o tempo todo demonstrar e defender a posição de nenhuma identificação com nenhum partido político. Uma das manifestações na rede afirma que no movimento "[...] nãa existe partido, oposição. Há apenas dois lados: os a favor e os contra Sarney". (PINHO et al., 2010) Isto sendo assim, qualquer participante será bem vindo desde que na condição de indivíduo, não de entidades organizadas. Nota-se no debate do grupo esse caráter apartidário do movimento, buscando evitar conflitos e polêmicas. Interessante perceber que esse comportamento se acentuaria nos movimentos de junho/13, mas ao se constatar sua presença em agosto/2009, mostra que isto é uma tendência contemporânea de recusa à política partidária, indicando um desgaste profundo desta, nos moldes tradicionais praticados.

Outra manifestação defende que as divergências partidárias e ideológicas devem ser esquecidas, sendo fundamental "nos concentrar no INIMIGO, não importa se a comunidade engloba petistas, democratas, comunistas, anarquistas, neoliberais, etc. O que realmente importa é a disposição de cada um em derrubar um político desonesto, torpe, nepotista, populista de mentalidade atrasada" [...]. Não vamos gastar energia com nós 
mesmos, vamos combater a ele, pois é ele que combatemos". (PINHO et al., 2010, grifo do autor)

Mesmo quando um participante insiste na ação através da filiação a um partido, os demais participantes desencorajam o debate reconhecendo que "Há o apartidarismo, mas não há omissão política". Um debate que também ocorreu se referiu à questão do debate virtual versus debate presencial. Com constância apareciam sugestões de realização de encontros presenciais entendendo que o Orkut cumpriria um papel de "ferramenta auxiliar", mas não seria "[...] o local apropriado para discutir detalhes da manifestação". Os defensores do ambiente virtual argumentam sobre "[...] as dificuldades de se reunir tantos participantes no meio da rua", onde diferentemente do meio virtual, em que todos poderiam ter acesso ao debate, nem todos poderiam estar presentes, "[...] padecendo assim as decisões de falta de representatividade". No entanto, existem razões mais profundas contra as assembleias presenciais, pois estariam embutindo "[...] o desejo de centralização das decisões nas mãos de alguns membros, que estariam buscando burocratizar o movimento e ganhar notoriedade junto à sociedade". Percebe-se assim que “[...] as divergências políticas vêm à tona, culminando no conflito quando são forçados a 'decidir a forma de decidir'”. (PINHO et al., 2010, grifo do autor)

O acompanhamento do número de adesões no meio digital (Orkut) revela um crescente que atinge 361 (em 17/10/2009), mas entrando logo em decadência registrando 347 (em 29/10/2009), 335 (em 11/11/2009), 324 (em 23/11/2009) e 313 (em 04/12/2009), ainda devendo ser acrescentado que este total de participantes se refere ao meio digital, pois, na prática, nas ruas, a adesão sempre foi bem menor. E o movimento se esvaziou, com a consequente perda de membros, com o arquivamento dos processos contra o senador José Sarney por parte do Congresso, levando a expressões do tipo: “[...] prá que lutar por uma causa que, tecnicamente, já está perdida?”. E, com isso, o movimento se esvaiu, levando a afirmações do tipo: "[...] várias pessoas estão saindo da comunidade" e "parece que o movimento parou. Ou acabou". (PINHO et al., 2010) 
Assim que esta situação se configurou, é postada uma mensagem, certamente de algum membro ou simpatizante do PV, com o sugestivo título: "Eu avisei" (PINHO et al., 2010, grifo do autor), lembrando ter observado que "[...] essa movimentação ia acabar em nada", pois "Não adianta tirar um coronel pois vai entrar outro”. Finaliza conclamando "Entrem em um partido, mostrem suas colocações, perspectivas, ideias inovadoras em gestão pública [...] Saudações Verdes”. Não fica sem resposta esta mensagem, sendo contra argumentado o seguinte: "Amei sua ideia, só faltou escrever uma coisa: E depois vire coronel também”, mostrando de forma compatível com o espírito hegemônico do grupo que entrar na política, nos partidos, representa uma capitulação a suas estruturas viciadas e viciantes. Ao que outro manifestante observa que "Quem tem formação paltada [sic] na ética, moralidade... não entra nesse ciclo...!", defendendo que seria possível encontrar um partido ético. A resposta é uma crítica ao papel dos partidos, quando um participante posta, já nos estertores do movimento ( 28 de novembro), com ironia que "participar de um partido político e se submeter ao sistema, adianta muito. Eu vejo o quanto ações partidárias mudam o Brasil. Em verdade, muda alguma coisa sim, as contas dos cofres públicos”. Esta postagem provoca a seguinte resposta de outro participante: "então, segundo você, temos um problema sem solução. [...] Eu acredito em MUDANÇAS”. Já entrando em dezembro e nas últimas postagens, outro participante assim se manifesta: "Ô, galera. Ser político não significa, necessariamente, desonestidade. Há políticos honestos, por aí, e acho que vocês sabem disso”. (PINHO et al., 2010, grifo do autor) Um participante retorna entendendo como derrota, a "derrota que o povo brasileiro sofreu no senado" e sentindo que "nem vocês, nem os outros conhecem uma solução". Ainda acrescenta que todos ficam perdidos e que, por ficarem "apedrejando uns aos outros, mostram não ter sensibilidade e até mesmo maturidade para buscar uma resposta decente, coerente e justa". (PINHO et al., 2010, grifo do autor) Toda essa discussão reflete bem como a juventude se localiza frente ao sistema partidário do país, revelando um profundo niilismo com relação a este. 
Outra participante expressa que "as pessoas de bem não podem pensar apenas em manifestações [...] elas têm que buscar um meio de mostrar e fazer como se deve ser feito, com ética[...]". Prossegue exemplificando, com várias políticas públicas que não sofrem questionamento, concluindo em letras garrafais (como se estivesse gritando) que "A OMISSÃO PÚBLICA É UM DOS NOSSOS PROBLEMAS”. Esta manifestação não passa em branco, recebendo o comentário: "Existem politicos honestos? Deve existir... Existe partido político honesto? Não! Ha ha. Essa é a diferença, o PT/PC do B já foi tudo que o PSTU/PSOL, PV é hoje, tendência incontestável. A corja prevalece, o dinheiro manda e faz girar o mundo. Prefiro me manter apartidário". Esta postagem faz emergir um questionamento sucinto: “Alienação é a solução?” (PINHO et al., 2010, grifo do autor) obtendo uma longa resposta (em 19/12) que finaliza a comunidade na rede:

Mister [nome fictício], não é coerente desqualificar este movimento. Foi um movimento espontâneo, nada mais político! A questão não é de como iria acabar este movimento, o fato mais relevante é que ele começou, ele surgiu. A luta política nos partidos é um caminho, claro... Mas não seja legalista, a política nasceu antes e independentemente de partidos políticos. A voz do cidadão, como influente na sociedade, seja como consumidor, como crítico, como eleitor ou como político é igualmente relevante. Este movimento não quis lutar em favor de uma posição-proposta política específica. Mas isso não é motivo para que ele seja classificado como sem sentido. Ao contrário, foi um movimento, ao meu ver, em favor da política democrática ou, melhor, do espaço democrático na política e, por isso, é automaticamente contrário a ações como a do nosso querido senador. O movimento, como disse certa vez nessa comunidade, não tem o sentido de resolver os problemas da política brasileira, depondo um presidente do senado, não. Esta deposição é só uma ação direta e visivel. A bandeira do movimento é maior, ela diz respeito, como disse, à ética na política, ela diz respeito à participação dos jovens e demais cidadãos na política. E a própria existência deste movimento já foi significativa em todos esses sentidos. Antes de desqualificar, devemos fazer o possivel pra que este movimento não morra. O brasileiro precisa entender que a política o atinge e que 
ela não deve ser um mundo à parte do que ele vive e nem que seu papel de cidadão se finde com a votação tampouco com a filiação a um partido. (PINHO et al., 2010, grifo do autor)

Sintetizando, parece possível abrigar a análise feita da comunidade e do movimento em quatro grandes compartimentos: 1) visão profundamente negativa da política partidária, tentando manter a posição apartidária do movimento, levando, inclusive, ao limite de recusar a participação de filiados a partidos políticos; 2) forte tendência a abrandar e evitar conflitos e discussões sobre divergências entre os membros do movimento; 3) forte ambiguidade em relação à mídia tradicional, pois, por um lado, criticavam a posição da mídia ao não registrar ou não dar a devida cobertura às manifestações, por outro lado, sentindo a necessidade de que isso acontecesse, que o movimento só seria viável se vazasse para a mídia convencional; 4) não havia exatamente um líder, algum participante que se destacasse e chamasse para si a responsabilidade do movimento, o que, em parte, o aproxima do MPL, nesse quesito. Por não ter um interlocutor explícito, uma liderança que se sobressaísse, essa característica pode ter levado o movimento ao fracasso.

Notar que, nos protestos de 2013, o grupo que comandava o MPL já tinha uma tradição de organização e mobilização construída em manifestações anteriores. O grupo que constitui o FS se constrói para aquele momento, não tinha qualquer tradição ou experiência em realizar manifestações e se dissolve com o arquivamento da denúncia contra Sarney, ou seja, são dois movimentos e grupos com constituições radicalmente diferentes. Cabe uma última palavra mais de ordem metodológica sobre a análise dessa material. A coleta das manifestações da própria comunidade no meio digital mostra-se bastante positiva, pois são colhidas as palavras dos participantes. Na metodologia da análise do meio presencial, o que acontece nas ruas, embora possa se recolher elementos mais concretos (a violência, gestos, o vestuário, etc.), faltam palavras, ainda que estas possam estar presentes nos cartazes, embora estáticos. 


\section{A REVOLTA DO VINTÉM}

Nesta seção, será feita uma breve descrição do que foi a chamada Revolta do Vintém ocorrida no Rio de Janeiro. Para tanto, vamos recorrer, basicamente, à análise efetuada por Ronaldo Pereira de Jesus que se valeu de pesquisa detalhada em jornais da época. Ela teve origem na instituição do "imposto do vintém" ainda no Império anunciado em dezembro de 1879 , para entrar em vigor em $1^{\circ}$ de janeiro de 1880. O imposto tinha como objetivo conter o déficit do reinado, através da cobrança de um vintém (que correspondia a 20 réis, a moeda da época) sobre o valor das passagens dos bondes no Rio de Janeiro, capital do Império. A partir do anúncio do imposto, "[...] mobilizações de protesto foram encabeçadas por publicistas e políticos, especialmente os republicanos, em geral membros dos setores médios urbanos" que visavam a capitalizar "[...] o descontentamento generalizado da população mais humilde da corte, assolada pela carestia, pelo desemprego, pelas precárias condições sanitárias e pela falta de moradia”. Ainda antes da entrada em vigor do novo imposto, "[...] uma multidão se reuniu para expressar, em praça pública, seu descontentamento com a medida governamental" devido o baixo nível de vida da maioria da população da cidade. Foram contidos e dispersados pela força policial ao tentarem entregar ao imperador um manifesto de repúdio ao novo imposto. As manifestações coletivas de protesto duraram de 28 de dezembro de 1879 a 4 de janeiro de 1880 , enfeixando o que veio a ser conhecido como a Revolta do Vintém. Buscando uma explicação teórica para o evento, Ronaldo Pereira de Jesus (2006, p. 73-74) recorre à Sandra Graham, que descreve os participantes que

[...] mesmo estando em certa medida afastados das instâncias partidárias, teriam se convertido numa 'fonte de poder até então nunca utilizada', capaz de transformar a 'violência da rua' em parte da 'equação política' e, assim, 'arrastar a política das salas do parlamento para as praças da cidade'.

Olhando mais de perto a própria construção do imposto, ainda em fase de discussão, a imprensa já se mostrava contra o novo imposto, 
apresentando o argumento de que este incidiria de "[...] modo indiscriminado sobre cidadãos e súditos com rendimentos desiguais”, não fazendo distinção entre "[...] um rico comerciante que habitava uma chácara em Botafogo, ou um operário humilde residente num casebre na Cidade Nova". A isto se adicionava o argumento de que a população rica procurava os bairros mais afastados por "prazer ou luxo", enquanto que os mais pobres procuravam os "[...] bairros mais distantes, em geral mais insalubres" por conta dos preços mais baixos de aluguel. E para este grupo, o transporte por bonde era indispensável para chegar ao centro da cidade. Assim, "[...] às vésperas do Natal de 1879, o imposto do vintém era considerado por toda imprensa como uma medida extremamente impopular". Nesse clima e com uma "[...] intensa circulação de boatos a respeito de uma grande manifestação popular" marcada para a data de início da cobrança do imposto, “[...] alguns jornais começaram a pedir 'calma' e 'reflexão' para aqueles decididos em contestar as medidas do governo". (JESUS, 2006, p. 75) Se do ponto de vista da imprensa esta era sua posição, do ponto de vista governamental é editada uma nota, logo após o Natal, proibindo "reuniões públicas” bem como "manifestação da liberdade de expressão", colocando em alerta as forças policiais da corte, o que veio a gerar alertas da imprensa situacionista contra "a intransigência do poder público". Apesar de todas essas medidas, uma primeira manifestação pública contra o imposto ocorreu em 28 de dezembro, quando "[...] cerca de cinco mil pessoas se reuniram no Campo de São Cristovão para ouvir o Doutor Lopes Trovão", um médico e jornalista e ativo militante republicano e abolicionista, que falou à multidão da janela de um sobrado, defendendo levar uma petição ao imperador, solicitando a revogação do imposto. Liderada pelo orador, a multidão se deslocou em direção ao Paço da Boa Vista, onde se encontrava o imperador. No deslocamento, foi "intimado" a interromper a jornada por delegados e "[...] mais de cem agentes armados de longos e grossos cacetetes", o que levou Lopes Trovão a “[...] não ceder às intimidações, justificando se tratar de uma mobilização pacífica”. (JESUS, 2006, p. 77) O imperador, no entanto, não aceitou receber os manifestantes, se dispondo, mais tarde, a 
receber apenas uma comissão, mas esta se recusou a aceitar a decisão tardia do imperador. Registre-se que, assim, não ocorreu violência na manifestação, ainda que tenha ficado latente. O mesmo não ocorreu dias depois com a implantação do novo imposto e quando o movimento de protesto passaria "[...] a incluir outros segmentos da população carioca menos 'ordeiros' e a 'civilidade' no episódio da tentativa de entrega da petição ao imperador ficaria definitivamente para trás”. No primeiro dia do ano de 1880 , ainda que algumas empresas de bondes não estivessem cobrando do vintém e que Lopes Trovão conclamasse a população "[...] a resistir pacificamente à cobrança do imposto" em discurso no Largo do Paço, as pessoas reunidas se deslocaram pelas ruas do centro da cidade entre "[...] vaias e manifestações de descontentamento", chegando até estações de bondes, iniciando-se "[...] a depredação dos bondes e o conflito direto com as forças policiais". (JESUS, 2006, p. 78)

Havia "uma lógica quase idêntica" de protesto nas várias ruas, qual seja, “[...] os manifestantes tomavam os bondes, espancavam os condutores, esfaqueavam os animais usados como força de tração, despedaçavam os carros, retiravam os trilhos e, com eles, arrancavam as calçadas”. Com os destroços, faziam barricadas respondendo à polícia “[...] com insultos, pedradas, garrafadas e até com tiros de revólver". Ao longo desse dia, primeiro do ano, a polícia respondia aos vários focos de protesto, “[...] quase sempre atirando contra a multidão". Os conflitos só foram encerrados às 21 horas, com o resultado de três manifestantes mortos e feridos, “[...] a maior parte por arma de fogo". No dia seguinte, face ao resultado produzido, construiu-se uma tentativa de acordo com o governo, tanto por parte dos políticos mais conservadores como pelos publicistas "mais exaltados" contra o imposto. No entanto, nas ruas, o protesto tinha seguimento, "[...] já sem o apoio de seus principais idealizadores" e o governo se posicionando que estaria disposto a negociar, mas que não admitiria a quebra da ordem pública e nem a formação "grandes massas de povo" frente ao palácio imperial (JESUS, 2006, p. 79-80). No que se refere ao sepultamento das vítimas, afirmava que não fossem feitas manifestações como as feitas por 
ocasião da Revolução Francesa. Interessante notar que passado quase um século da revolução em França, esta parecia estar pairando como uma ameaça aos monarquistas.

Já no dia 2 de janeiro, novas manifestações irromperam, sendo dispersas pela Polícia e sendo várias pessoas presas. No dia seguinte, o número de escaramuças se reduziu, dia em que senadores e deputados da oposição, contando com a participação de Lopes Trovão, José do Patrocínio e outros se reuniram para redigir "[...] um manifesto contra o vintém” e conclamando o povo à paz e à ordem. No dia 4 de janeiro, com "[...] cerca de cem pessoas reunidas no Largo de São Francisco, foram abordadas pela força policial e responderam com pedradas, pauladas e garrafadas", a maioria deles caixeiros das casas comerciais do centro da cidade. Neste dia, termina a Revolta do Vintém, a partir de “[...] relações estabelecidas entre as classes populares da corte e o Estado monárquico", “[...] depois de interrompida a arrecadação pelo protesto popular". No dia seguinte, um importante jornal, Jornal do Commercio, arrolava os principais segmentos sociais presentes nas manifestações: "[...] a juventude das escolas, cheia de nobre, mas indefinido entusiasmo por tudo o que lhe agita a fibra sensível das generosas paixões", ao lado dos que se sentiam prejudicados pela política dominante, sem exatamente sem nomear quais eram. Todos estes pertenciam "[...] aos setores médios urbanos e à elite da corte”. (JESUS, 2006, p. 81-82) Ao lado destes, agregava o jornal, vinha o "segmento popular" visto pelo jornal como aquele que

[...] na sinceridade de sua crassa ignorância e sob o agulhão das privações diurnas, estão sempre prontos a condenar os governos, sejam quais forem, que não realizem o ideal impossível e sobrenatural de dirigirem a sociedade de modo que não pague impostos e que todas vivam contentes no seio de uma abundância fácil e sem trabalho. (JESUS, 2006, p. 82)

Por outro lado, "publicistas e políticos antimonarquistas atribuíam as causas da Revolta do Vintém à impopularidade do regime imperial e ao desgaste da imagem de D. Pedro II entre a maior parte da população da cidade do Rio de Janeiro". Encerrados os conflitos, isto não viria a 
provocar "grandes alterações" na Monarquia nem na figura do Imperador para a maioria da população. Encerra Pereira de Jesus, afirmando que

a Revolta do Vintém ocasionou muito mais a alteração radical e momentânea das atitudes e expectativas diante do regime político e do Imperador, do que uma mudança significativa e duradoura no imaginário popular, nas representações das pessoas comuns acerca da Monarquia. (JESUS, 2006, p. 87)

\section{ANÁLISE DOS MOVIMENTOS E CONCLUSÕES}

Feita essa exposição de elementos básicos para compreensão desta Revolta, passamos agora para uma tentativa de análise de aproximação ou diferenciação entre os movimentos acima analisados. Desnecessário enfatizar que existe um abismo de tempo e condições entre a última década do Império, e penúltima do século XIX, e os movimentos recentes de 2009 e 2013. Em que pesem essas diferenças explícitas, algumas convergências chamam a atenção. Em primeiro lugar, a questão do transporte parece mobilizar as populações. Conforme assinalado ao início deste artigo, no transporte é que a população sente, de forma direta e imediata, o "assalto" ao seu bolso. Ainda que possa encontrar uma alternativa ao pagamento com o deslocamento a pé, isso nem sempre é possível, ainda mais em uma cidade grande onde horários são impostos à classe trabalhadora bem como a estudantes. Assim, uma parcela da população se torna escrava do transporte coletivo, população esta expulsa para a periferia, quer seja no final do regime monárquico, quer seja mais de um século depois em períodos autoritários ou democráticos. Uma segunda questão também merece destaque, exatamente a participação de uma população jovem formada por estudantes, o que vem a se repetir nos dois outros movimentos focados.

Merece ainda atenção o fato de que a tão cantada passividade da população brasileira parece vir por terra quando se analisa, principalmente, essa Revolta do Vintém. Evidentemente, o ambiente é bem quente do ponto de vista político com a emergência do movimento republicano 
e também abolicionista. Assim, a luta não era pelos 20 Réis (1 vintém), mas tinha um forte conteúdo político de minar a autoridade da Monarquia e do Monarca. Mas, também, todas essas manifestações têm que ser olhadas com cautela, pois, ao mesmo tempo que a sociedade explode, parece que se recolhe a uma outra longa hibernação voltando a explodir. Ou seja, parece que a sociedade se comporta espasmodicamente, com sístoles e diástoles. Também Pereira de Jesus observa que a Revolta do Vintém também não representou o abalamento do regime monárquico, com a ordem estabelecida se recompondo. Observa, ainda, que superada a Revolta do Vintém, o Império ainda leva quase dez anos para cair, e quando isto acontece, a massa urbana assiste a tudo "bestializada", conforme registrado por José Murilo de Carvalho (1987), não tendo noção de que ali se consumia a implantação da República.

Parece que esta tem sido a tendência dominante no Brasil no largo prazo. Ao se observar os movimentos mais representativos das últimas décadas, conforme já apontado, após os movimentos das Diretas Já (1984), tivemos os Caras Pintadas (1992), e os movimentos de junho/13, isto quer dizer, uma explosão a cada década ou mais. Assim, os movimentos têm que ser saudados com importância e ânimo, mas sem grandes expectativas de que tudo vai mudar e rapidamente. No caso desses últimos movimentos, vale observar que sendo "Estopim dos protestos de junho de 2013 pelas ruas do país, a discussão sobre tarifa e qualidade do transporte coletivo nas regiões metropolitanas não atingiu em cheio a campanha presidencial" (GERARQUE; MONTEIRO, 2014), sendo que esta campanha se deu pouco mais de um ano depois dos protestos, dando a impressão de que havia saído da pauta.

Em outra esfera, vale comentar que, evidentemente, à época da Revolta do Vintém não havia os recursos digitais existentes agora, mas houve uma mobilização impressionante em uma sociedade ainda escravocrata, onde a palavra democracia não reverberava, não tinha qualquer acolhimento. O Rio de Janeiro, com uma população que pode ser estimada em cerca de 400 mil habitantes (247.972 pelo Censo de 1872, e 522651 pelo Censo de 1890, segundo o IBGE) consegue mobilizar, naquele contexto, cerca de 5 mil pessoas para manifestações que 
duram quatro dias seguidos, mostra que existem formas de mobilizar as massas que transcendem as comunicações digitais. Este artigo enfatiza este aspecto, pois existe uma tendência muito forte, atualmente, de imputar as tecnologias o fato das participações políticas. Não desprezando, evidentemente, o poder que estas têm de levar o cidadão às ruas não é só questão de comunicação, conforme já apontado no quadro teórico.

Quando se coteja o FS com o junho/13, já se nota, evidentemente, uma aproximação maior e mais facilmente identificada, principalmente no que se refere às tecnologias de comunicação, embora também neste quesito, apesar do pouco tempo decorrido entre um e outro, já exista um finado, o Orkut, superado pelas redes sociais mais potentes e interativas. Outra diferenciação também tem que ser feita. A apropriação do que foram esses movimentos foi feita de maneira diferenciada. Se no caso do FS acompanhou-se o movimento "por dentro", ainda que no ambiente digital, no caso do Junho/13, foi feita pelos registros da imprensa e por construções teóricas de analistas políticos. Ainda outra diferenciação merece ser apontada: o caso do FS tinha um foco específico, perseguia a remoção, a cassação do senador Sarney, enquanto o Junho/13, como sabemos, tinha, a princípio, um foco no questionamento do aumento de passagens, explodindo, em seguida, para uma pauta ampla e diversificada de questionamentos e demandas, todas na área política.

A capacidade de mobilização do FS, não apenas no caso acompanhado de Salvador como em outras capitais do Brasil, capacidade muito menor do que a identificada no Junho/13, pode apontar que mobilizações contra a corrupção parecem difíceis de emplacar, não motivam as populações como se estivessem a ver que estão batalhando por uma causa perdida, enquanto que no caso do Junho/13 a luta pela tarifa era mais concreta, ainda que tenha derivado para essa agenda pluri, conforme apontado.

Outra convergência pode ser apontada entre esses dois movimentos recentes, a participação intensa de jovens, mas principalmente jovens de classe média e média alta, estudantes em parte considerável do 
nível médio. Se isso pode ser saudado como positivo, também preocupa no sentido de uma inclusão não tão forte de um público universitário. Também foi observado que existe uma fuga às formas tradicionais de fazer política e filiação a partidos políticos. Se esta é uma tendência mundial, do mundo ocidental principalmente, por razões sobejamente conhecidas, isto se agrava no Brasil, com todo o desalento com a política, os políticos e os partidos políticos.

Para encerrar, a análise acima, se transpira certo pessimismo, isto deve ser relativizado. Por um lado, no sentido de evitar cair em uma euforia não consistente. A partir da máxima de que não existe "almoço grátis", pode-se contrapor que "não existe revolução grátis” ou, se não se almeja tanto, "não existem mudanças grátis". Assim, o papel de todos esses movimentos coletivos tem que ser valorizado no sentido da construção de uma sociedade mais justa e igualitária no Brasil, mas sem cair na tentação de que tudo vai ser alcançado fácil e automaticamente.

Ainda uma inquietação que esta análise gera. A política parece estar sendo permeada pelas redes. Quando os próprios manifestantes diziam em junho/13 para sair do Facebook, da internet e vir para as ruas, evidentemente se sabe que não dá para ficar nas ruas o tempo todo, mas existe um risco (risco?) de que os jovens voltem às redes até outro despertar, até por entender que esta é a maneira mais fundamental e decisiva de se fazer política. Uma última reflexão, acima já arranhada, cabe à questão: por que algumas manifestações pegam e outras não pegam? Alguns analistas têm apontado que, diferentemente do que pregavam os manifestantes, a manifestação não era pelos vinte centavos. o que se assistiu foi que, assim que a demanda da revogação do aumento das passagens foi atendida, o movimento recuou e se esvaziou. E a longa pauta que "pegou carona" no movimento da MPL, praticamente não foi atendida, ressalvada, em parte, como dito, a questão da saúde com o "Mais médicos". Como vários autores usaram a metáfora da fagulha, faísca e estopim, podemos pensar nos movimentos como uma caixa de fósforos, onde nem todos que são riscados funcionam. 


\section{REFERÊNCIAS}

AGRE, P. Criando uma cultura da internet. Revista USP. São Paulo, n. 35, set./nov. 1997. Dossiê Informática/Internet.

CARVALHO, J. M. O Rio de Janeiro e a República que não foi. Rio de Janeiro: Cia das Letras, 1987.

CASTELLS, M. A Sociedade em Rede. São Paulo: Paz e Terra, 1999.

CASTELLS, M. Internet e sociedade em rede. In: MORAES, D. (Org.). Por uma outra comunicação: mídia, mundialização cultural e poder. Rio de Janeiro: Record, 2003. Cap. 11.

CASTELLS, M. A galáxia da internet: reflexões sobre a internet, os negócios e a sociedade. Rio de Janeiro: Zahar, 2003.

CASTELLS, M. Redes de indignação e esperança: movimentos sociais na era da internet. Rio de Janeiro: Zahar, 2013.

ECO, U. Entrevista. “O Professor Aloprado”, Folha de São Paulo, São Paulo, 11 maio 2008.

GERAQUE, E.; MONTEIRO, A. Não é por R\$o,20, Folha de São Paulo, São Paulo, 23 set. 2014. Eleições 2014, p. A8.

FORASARNEY. In: WIKIPÉDIA a enciclopédia livre. Português. 2009. Disponível em: <http://pt.wikipedia.org/wiki/Forasarney>. Acesso em: 10 maio 2014 .

GOHN, M. da G. As manifestações de junho de 2013 e os movimentos sociais. Disponível em: <http://www.unipress.blog.br/as-manifestacoesde-junho-de-2013-e-os-movimentos-sociais-por-maria-da-gloria-gohn/>. Acesso em: 22 jan. 2015 .

IASI, M. L. A rebelião, a cidade e a consciência. In: MARICATO, E. et al. Cidades rebeldes: Passe Livre e as manifestações que tomaram as ruas do Brasil. São Paulo: Boitempo: Carta Maior, 2013.

IBOPE. Pesquisa IBOPE sobre as Manifestações em 8 capitais. 20 jun. 2013.

JESUS, R. P. de. A Revolta do Vintém e a Crise na Monarquia. História Social, Campinas/SP, n. 12, p. 73-89, 2006. 
KUCINSKYI, B. Informática e liberdade. In: SANTOS, L. et al. Revolução tecnológica, internet e socialismo. São Paulo: Ed. Fundação Perseu Abramo, 2003. p. 59-82. (Coleção Socialismo em Discussão).

LIMA, V. A. de. Mídia, rebeldia urbana e crise de representação. In: MARICATO, E. et al. Cidades rebeldes: Passe Livre e as manifestações que tomaram as ruas do Brasil. São Paulo: Boitempo: Carta Maior, 2013. LÖWY, M. Entrevista. Estado de São Paulo, São Paulo, 29 dez. 2013. MAMEDE-NEVES, M. A. et al. Problemas e valores apontados por jovens universitários pertencentes a sociedades emergentes: um estudo sobre a Barra da Tijuca. Revista de Comunicação, Cultura e Política, Rio de Janeiro, v. 4, n. 7, p. 164-195, jul./dez. 2003.

MARICATO, E. É a questão urbana, estúpido! In: MARICATO, E. et al. Cidades rebeldes: Passe Livre e as manifestações que tomaram as ruas do Brasil. São Paulo: Boitempo: Carta Maior, 2013.

MARTINS, J. de S. A política no Brasil: lúmpen e místico. São Paulo: Contexto, 2011.

MARTINS, J. de S. A pauta escamoteada. Estado de São Paulo, São Paulo, 29 dez. 2013, Caderno Aliás.

MOVIMENTO PASSE LIVRE. Não começou em Salvador, não vai terminar em São Paulo. In: MARICATO, E. et al. Cidades rebeldes: Passe Livre e as manifestações que tomaram as ruas do Brasil. São Paulo: Boitempo: Carta Maior, 2013.

NOGUEIRA, M. A. As ruas e a democracia: ensaios sobre o Brasil Contemporâneo. Brasília, DF: Fundação Astrojildo Pereita; Rio de Janeiro: Contraponto, 2013.

PESCHANSKI, J. A. O transporte público gratuito, uma utopia real. In: MARICATO, E. et al. Cidades rebeldes: Passe Livre e as manifestações que tomaram as ruas do Brasil. São Paulo: Boitempo: Carta Maior, 2013.

PINHO, J. A. G. de. Investigando portais de governo eletrônico de estados no Brasil: muita tecnologia, pouca democracia. RAP, Rio de Janeiro, v. 42, n. 3, 2008. 
PINHO, J. A. G. de. Sociedade da informação, capitalismo e sociedade civil: reflexões sobre política, internet e democracia na realidade brasileira. RAE, São Paulo, v. 51, n. 1, jan./fev., 2011.

PINHO, J. A. G. de et al. Internet e democracia: uma investigação preliminar do movimento Fora Sarney em Salvador no Orkut. Mimeo. 2010 .

RHEINGOLD, H. La comunidad virtual: uma sociedade sin fronteiras. Barcelona: Gedisa Editorial, 1996.

ROLNIK, R. Apresentação: as vozes das ruas: as revoltas de junho e suas interpretações. In: MARICATO, E. et al. Cidades rebeldes: Passe Livre e as manifestações que tomaram as ruas do Brasil. São Paulo: Boitempo: Carta Maior, 2013.

SANTOS, L. G. Debate com o público. In: SANTOS, L. G. et al. Revolução tecnológica, internet e socialismo. São Paulo: Ed. Fundação Perseu Abramo, 2003. p. 59-82. (Coleção Socialismo em Discussão).

SECCO, L. As Jornadas de Junho. In: MARICATO, E. et al. Cidades rebeldes: Passe Livre e as manifestações que tomaram as ruas do Brasil. São Paulo: Boitempo: Carta Maior, 2013.

SINGER, A. Brasil, junho de 2103: Classes e ideologias cruzadas. Novos Estudos. CEBRAP, São Paulo, n. 97, nov. 2103.

SORJ, B.Brasil@povo.com: a luta contra a desigualdade na sociedade de informação. São Paulo: Zahar; Brasília: Unesco, 2003.

VAINER, C. Quando a cidade vai às ruas. In: MARICATO, Ermínia et al. Cidades rebeldes: Passe Livre e as manifestações que tomaram as ruas do Brasil. São Paulo: Boitempo: Carta Maior, 2013. 


\section{SERVIÇOS DE GOVERNO ELETRÔNICO}

um panorama do uso no Brasil

ERNANI MARQUES DOS SANTOS, NICOLAU REINHARD

INTRODUÇÃO

Um dos principais objetivos da implementação do governo eletrônico é proporcionar o acesso às informações e serviços públicos demandados pela sociedade em geral, de forma a satisfazer as necessidades dos usuários e suas expectativas.

A forma de operacionalização do governo eletrônico é por meio da prestação de serviços eletrônicos - serviços que são oferecidos, fornecidos e/ou consumidos pela internet. (SWID; ELMELEGY, 2012)

No entanto, embora tenha sido cada vez mais crescente o acesso às tecnologias de informação e comunicação, notadamente em relação à internet, entre a oferta e o uso desses serviços nem sempre existe uma correlação direta. A adoção e o uso dos serviços dependem de muitos fatores, dentre eles a utilidade percebida, percepção de facilidade de uso, preocupações de risco inerente (HOFFMAN; NOVAK; PERALTA, 1999) e confiança. (LEE; KIM; AHN, 2011) Além disso, a implementação de governo eletrônico envolve muitos grupos de diferentes stakeholders, que precisam ser levados em consideração no desenvolvimento dos serviços a serem disponibilizados. (FLAK et al., 
2007; TRANMÜLLER; WIMMER, 2000) Janssen e Cresswell (2005), e Kamal, Weerakkody e Irani (2011) também enfatizam que as iniciativas de governo eletrônico envolvem iniciativas de stakeholders de dentro e de fora da organização.

A partir desse cenário, o objetivo do presente artigo é analisar o uso do governo eletrônico no Brasil, a fim de traçar um perfil da utilização desses serviços e suas motivações para o não uso. Para tanto, utiliza-se os dados coletados nas pesquisas TIC Domicílios 2009 a 2013, realizadas pelo Centro Regional de Estudos para o Desenvolvimento da Sociedade da Informação (CETIC.br), do Núcleo de informação e Coordenação do Ponto BR (NIC.br) - braço executivo do Comitê Gestor da Internet no Brasil (CGI.br). Esta pesquisa investiga a posse e o uso das Tecnologias de Informação e Comunicação (TICs) no Brasil, em várias áreas, sendo que aqui foca-se especificamente nos dados referentes a governo eletrônico. Embora seja senso comum que esses serviços podem trazer benefícios para a sociedade e também para o governo, seu uso ainda pode ser considerado pequeno frente ao potencial e importância.

\section{GOVERNO ELETRÔNICO}

Para Grande, Araujo e Serna (2002) o termo governo eletrônico não possui uma clara definição. Várias conceituações, notadamente de instituições, são encontradas: National Audit Office (2002), Organização para a Cooperação e Desenvolvimento Econômico (2001), United Nations (2001), European Public Administration Network (2004), Intosai (2003) e Okot-Uma (2001), entre outras.

Para o World Bank (2003),

governo eletrônico refere-se ao uso, por agências governamentais, de tecnologias de informação (como redes de longa distância, internet e computação móvel) capazes de transformar as relações com cidadãos, empresas e outras unidades do governo. Essas tecnologias podem servir a diferentes fins, como: melhor prestação de serviços aos cidadãos, interações mais eficazes com empresas e a indústria, empowerment do cidadão por meio do acesso a informações ou mais eficiência na administração governamental. 
Criado e Ramilo (2001) apresentam uma definição mais ampla, referindo-se à adoção de Tecnologias de Informação e Comunicação pela Administração Pública como diferentes vias através das quais organizações se conectam e interagem com outras organizações e pessoas, especialmente mediante suas páginas web, mas também através de correio eletrônico e outras ferramentas como telefone e outros dispositivos móveis, vídeo conferência, intranets privadas, extranets, TV a cabo, ondas de rádio e satélites.

Em linhas gerais, as funções características do governo eletrônico são (SANTOS; REINHARD, 2012, p. 121-122):

- prestação eletrônica de informações e serviços;

- regulamentação das redes de informação, envolvendo principalmente governança, certificação e tributação;

- prestação de contas públicas, transparência e monitoramento da execução orçamentária;

- ensino a distância, alfabetização digital e manutenção de bibliotecas virtuais;

- difusão cultural com ênfase nas identidades locais, fomento e preservação das culturas locais;

- e-procurement, isto é, aquisição de bens e serviços por meio da internet, como licitações públicas eletrônicas, pregões eletrônicos, cartões de compras governamentais, bolsas de compras públicas virtuais e outros tipos de mercados digitais para bens adquiridos pelo governo;

- estímulo aos negócios eletrônicos, através da criação de ambientes de transações seguras, especialmente para pequenas e médias empresas.

Essas funções, ao serem realizadas, envolvem basicamente quatro tipos de transações (SANTOS; REINHARD, 2012, p. 122):

$\mathrm{G}_{2} \mathrm{G}$, quando se trata de uma relação intra ou inter-governos; $\mathrm{G} 2 \mathrm{~B}$, caracterizado por transações entre governos e pessoas jurídicas em seus vários papéis desempenhados; e $\mathrm{G} 2 \mathrm{C}$, envolvendo relações entre governos e cidadãos; e G2E, relacionadas às transações entre governos e seus próprios servidores. 
A implementação de governo eletrônico é um processo que pode apresentar estágios distintos, tendo em vista os níveis de informações e serviços prestados. Várias classificações têm sido formuladas, como, por exempo, Gartner Group - Baum e Maio (2000), Deloitte e Touche (2001), Hiller (2001), Layne e Lee (2001), Moon (2002), United Nations (2001) e Siau e Long (2004).

O modelo proposto pelas Nações Unidas (2001), estabelece cinco estágios: (1) presença emergente; (2) presença aprimorada; (3) presença interativa; (4) presença transacional e; (5) presença em rede. Esse último estágio é definido como uma estrutura $\mathrm{G}_{2} \mathrm{C}$ (governo para cidadão) baseada em uma rede integrada de agências públicas para a provisão de informação, conhecimento e serviços (Quadro 1).

Quadro 1 - Estágios de governo eletrônico

\begin{tabular}{|c|c|}
\hline ESTÁGIO & CARACTERÍSTICAS \\
\hline $\begin{array}{l}\text { I - Presença } \\
\text { Emergente }\end{array}$ & $\begin{array}{l}\text { Presença na web por meio de um website oficial, um portal nacional ou } \\
\text { uma home page oficial; links para os ministérios do governo, governos } \\
\text { estaduais e locais, administração indireta; a informação é limitada, } \\
\text { básica e estática. }\end{array}$ \\
\hline $\begin{array}{l}\text { II - Presença } \\
\text { Aprimorada }\end{array}$ & $\begin{array}{l}\text { Serviços on-line são aprimorados para incluir bases de dados e fontes } \\
\text { de informações atuais e arquivadas, como políticas, leis e regulação, } \\
\text { relatórios, informativos e bases de dados para serem baixadas pela } \\
\text { internet. O usuário pode procurar por um documento e há função de } \\
\text { ajuda e um mapa do sítio é disponibilizado. }\end{array}$ \\
\hline $\begin{array}{l}\text { III - Presença } \\
\text { Interativa }\end{array}$ & $\begin{array}{l}\text { Provisão de serviços on-line do governo entra no modo interativo; } \\
\text { facilidades para download online; link seguro; facilidade de assinatura } \\
\text { eletrônica; capacidade de áudio e vídeo para informação pública } \\
\text { relevante. Os servidores públicos podem ser contactados via e-mail, } \\
\text { fax, telefone e correio. O sítio é atualizado com grande regularidade. }\end{array}$ \\
\hline $\begin{array}{l}\text { IV - Presença } \\
\text { Transacional }\end{array}$ & $\begin{array}{l}\text { Usuários têm condições de conduzir transações on-line, como pagar } \\
\text { multas por transgressões no trânsito, impostos e taxas por serviços } \\
\text { postais por meio de cartão de crédito, bancário ou de débito. Há } \\
\text { algumas facilidades para licitar on-line em contratações públicas via } \\
\text { links seguros. }\end{array}$ \\
\hline $\begin{array}{l}\text { V - Presença } \\
\text { em Rede }\end{array}$ & $\begin{array}{l}\text { Uma estrutura } \mathrm{G}_{2} \mathrm{C} \text { (governo para cidadão) baseada em uma rede } \\
\text { integrada de agências públicas para a provisão de informação, } \\
\text { conhecimento e serviços. A ênfase está no feedback para o governo. } \\
\text { Um formulário de comentário na web é disponibilizado. Um calendário } \\
\text { de eventos governamentais futuros existe com um convite do governo } \\
\text { à participação. Governo solicita feedback por meio de mecanismos } \\
\text { de pesquisa de opinião on-line; fóruns de discussão; e facilidades de } \\
\text { consulta on-line. }\end{array}$ \\
\hline
\end{tabular}

Fonte: United Nations (2001). 
O estágio de presença em rede, como mencionado acima, pressupõe integração de sistemas antigos e desenvolvimento e implementação de novos sistemas dentro dessa perspectiva. Mas segundo Avgerou e colaboradores (2005), o suporte aos serviços de governo requer a transformação de sistemas legados implantados nas administrações públicas burocráticas em sistemas de informações modernos, o que se constitui numa tarefa bastante difícil, tanto no aspecto tecnológico como organizacional. Tecnologicamente, o desafio compreende a modernização e integração de sistemas fragmentados para formar uma infraestrutura capaz de suportar melhorias na prestação de serviços, como, por exemplo, possibilitar a redução ou eliminação da necessidade de acessar múltiplos órgãos do governo a fim de obter um serviço. (CIBORRA; NAVARRA, 2003) No plano organizacional, Avgerou e colaboradores (2005) argumentam que não existe um método instantâneo para se conseguir as mudanças necessárias para criar a capacidade da administração em melhorar a disponibilização de serviços públicos a longo prazo.

Segundo Oliveira (2003), no último estágio de implantação do governo eletrônico, as aplicações tornam-se mais avançadas e, ao efetuar uma transação com o governo, o usuário não precisa saber quais são os órgãos ou departamentos, de quais níveis de governo e em que sequência são mobilizados para obtenção de determinado serviço ou informação. O processamento das transações é feito de forma total através de um ambiente, provendo ao usuário a informação ou serviço solicitado por meio de um único ponto de acesso, o que tem sido denominado como "governo de parada única" ou "de janela única" (dos termos em inglês on-stop government e single-window service, respectivamente). (BENT; KERNAGHAN; MARSON, 1999; HAGEN; KUBICEK, 2000)

Corforme Santos e Reinhard (2012), de uma forma simplificada, a implementação de governo eletrônico pode se apresentar em três formas: presença na internet através de informações básicas, capacidades de transação para indivíduos e empresas e informações e transações integradas, com a colaboração entre diversas agências (janela única / governo de parada única). Os autores frisam, no entanto, que a con- 
cretização do último estágio envolve desafios políticos, estratégicos e procedimentais, nos quais a cooperação interagências é fundamental, além dos aspectos tecnológicos.

\section{METODOLOGIA}

O presente artigo baseia-se em dados coletados pelo Centro Regional de Estudos para o Desenvolvimento da Sociedade da Informação (CETIC.br), do Núcleo de informação e Coordenação do Ponto BR (NIC. br) - braço executivo do Comitê Gestor da Internet no Brasil (CGI.br), em sua pesquisa anual TIC Domicílios, ${ }^{\mathrm{I}}$ no período 2009-2013.

Os dados foram coletados de acordo com os padrões metodológicos e indicadores estabelecidos pela International Telecommunication Union (ITU), Organização das Nações Unidas (ONU), utilizando como referência o Manual for Measuring ICT Acess and Use by Households and Individuals. (ITU, 2014) Também foram observadas as orientações da OECD e do Instituto de Estatísticas da Comissão Europeia (Eurostat). Além disso, foram levadas em conta as orientações contidas nos documentos metodológicos produzidos pelo Observatório para a Sociedade da Informação na América Latina e Caribe (OSILAC), da Comissão Econômica para a América Latina e Caribe das Nações Unidas (CEPAL). O plano amostral utilizou informações do Censo Demográfico Brasileiro 2000 e 2010 (IBGE, 2000, 2010) e da Pesquisa Nacional por Amostra de Domicilio - PNAD 2008 a 2012 (IBGE, 2008, 2009, 2010, 2011, 2012), ambas realizadas pelo Instituto Brasileiro de Geografia e Estatística (IBGE). Na pesquisa TIC Domicílios 2013, as fontes para o desenho amostral foram as seguintes (Figura 1).

A pesquisa mede a disponibilidade e o uso das TICs e da internet em diversas áreas, sendo o questionário estruturado em blocos de perguntas, cobrindo os tópicos de acesso às TICs, uso do computador, uso da internet, segurança na rede, uso do e-mail, spam, governo eletrônico, comércio eletrônico, habilidades com o computador/internet, aces-

I A pesquisa TIC Domicílios é realizada anualmente desde 2005 e publicada no mês de junho do ano seguinte; no momento da elaboração deste artigo a última pesquisa disponível era a de 2013 , publicada em junho de 2014 . 
so sem fio (uso do celular) e intenção de aquisição de equipamentos e serviços TIC, além de um bloco inicial para caracterização socioeconômica dos respondentes. Para este artigo, foram utilizados apenas os dados referentes ao uso de serviços de governo eletrônico relativos às transações entre Governo e Cidadãos $\left(\mathrm{G}_{2} \mathrm{C}\right)$, considerando-se os usuários com 16 anos de idade ou mais, além de alguns dados do perfil socioeconômico dos pesquisados.

Figura 1 - Desenho amostral da pesquisa

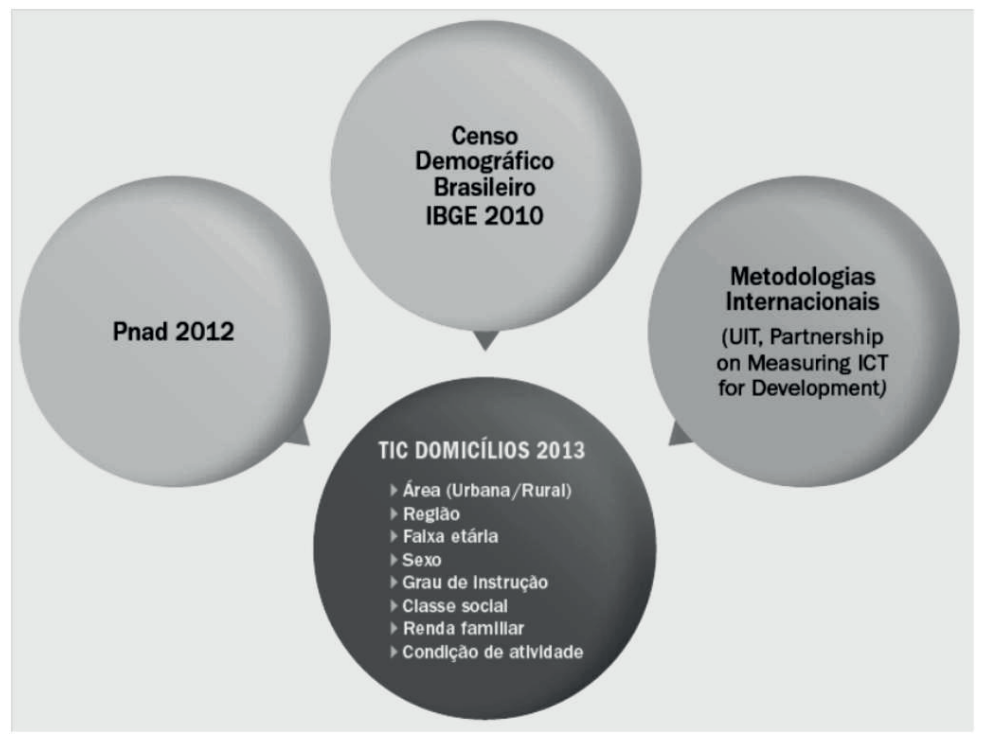

Fonte: CGI.br (2014).

\section{APRESENTAÇÃO E DISCUSSÃO DOS DADOS}

A título de caracterização dos seus respondentes, a pesquisa TIC domicílios 2013 apresentou os seguintes dados (CGi, 2014):

- distribuição geográfica: $43 \%$ pertenciam à região Sudeste; $27 \%$ à Nordeste; $15 \%$ à Sul; 8\% à Norte; e 7\% à Centro-Oeste.

- sexo: $52 \%$ eram do sexo feminino e $48 \%$ do sexo masculino. 
- grau de isntrução: $49 \%$ estavam cursando o Ensino Fundamental; 31\% o Ensino Médio; 13\% possuem o Ensino Superior; e 7\% eram analfabetos ou cursaram apenas a Educação Infantil.

- idade: $12 \%$ possuíam entre 10 e 15 anos; $17 \%$ entre 16 e 24 anos; $19 \%$ entre 25 e 34 anos; $17 \%$ entre 35 e 44 anos; $20 \%$ entre 45 e 59 anos; e $15 \% 60$ anos ou mais.

- distribuição de renda: $14 \%$ declararam possuir renda familiar de até um salário mínimo; 30\%, mais de um até dois salários mínimos; $21 \%$ declararam ter mais de dois até três salários mínimos; 13\%, mais de três a cinco salários mínimos; 7\%, mais de cinco até dez salários mínimos; e 4\%, mais de dez salários mínimos; $11 \%$ da amostra não souberam ou se recusaram a responder a renda familiar total do domicílio onde residem.

- classe econômica (segundo o Critério Brasil da Abep): 49\% da amostra pertencia à classe $\mathrm{C} ; 27 \%$ à classe $\mathrm{B} ; 22 \%$ às classes $\mathrm{D}$ e E; e apenas $2 \%$ à classe $\mathrm{A}$.

O uso de internet por parte dos pesquisados é apresentado no Gráfico 1, em relação à área de uso, região demográfica, sexo, nível de instrução, idade e classe econômica. Dois indicadores que chamam a atenção: o de instrução, com 93\% no nível superior e o de classe social, com $97 \%$ na classe A.

Segundo o CGi (2014, p. 176):

A massiva presença de computador e conexão de Internet em domicílios da classe A contribui para o amplo uso da rede entre os indivíduos dessa classe: $97 \%$ deles estavam conectados em 2013. Na classe B, a proporção de usuários também é alta, chegando a $78 \%$. Entretanto, permanece o desafio de universalização nas classes C (49\%) e, sobretudo, D e E (17\%). 
Gráfico 1 - Proporção de indivíduos que utilizaram internet - percentual sobre o total da população

\begin{tabular}{|c|c|c|}
\hline \multicolumn{2}{|l|}{ TOTAL } & 51 \\
\hline \multirow{2}{*}{ Área } & Urbana & 56 \\
\hline & Rural & 21 \\
\hline \multirow{5}{*}{ Região } & Sudeste & 56 \\
\hline & Nordeste & 42 \\
\hline & Sul & 56 \\
\hline & Norte & 39 \\
\hline & Centro-Oeste & 58 \\
\hline \multirow{2}{*}{ Sexo } & Masculino & 49 \\
\hline & Feminino & 53 \\
\hline \multirow{4}{*}{ Grau de instrução } & Analfabeto / Educação infantil & 2 \\
\hline & Fundamental & 32 \\
\hline & Médio & 74 \\
\hline & Superior & 93 \\
\hline \multirow{6}{*}{ Faixa etária } & De 10 a 15 anos & 75 \\
\hline & De 16 a 24 anos & 77 \\
\hline & De 25 a 34 anos & 66 \\
\hline & De 35 a 44 anos & 47 \\
\hline & De 45 a 59 anos & 33 \\
\hline & 60 anos ou mais & 11 \\
\hline \multirow{4}{*}{ Classe social } & $\mathrm{DE}$ & 17 \\
\hline & C & 49 \\
\hline & B & 78 \\
\hline & A & 9 \\
\hline
\end{tabular}

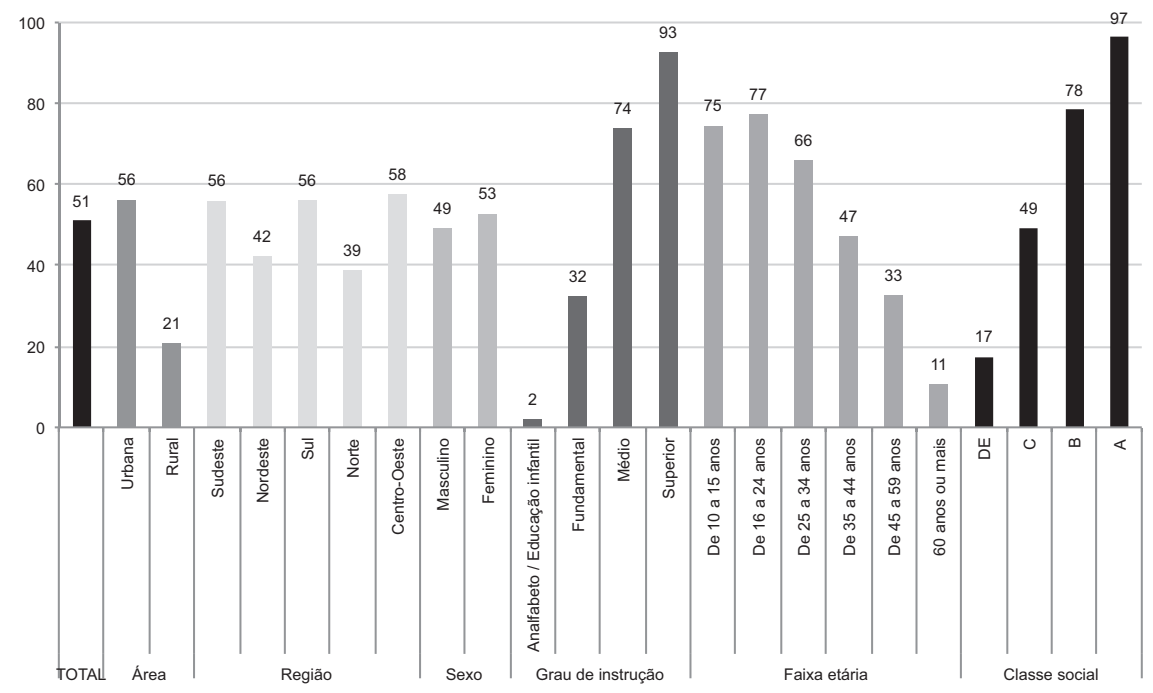

Fonte: CGI.br (2014). 
Ainda par o CGi (2014, p. 176):

Em números absolutos, o Brasil tem 69,9 milhões de pessoas a partir de 10 anos de idade que nunca usaram a Internet, sendo que a concentração maior está entre os brasileiros com mais de 45 anos - o equivalente a 42,6 milhões de pessoas. A mesma desigualdade pode ser observada por renda. Indivíduos que residem em domicílios com renda média familiar que não ultrapassa dois salários mínimos representam 43 milhões de brasileiros excluídos digitalmente. Entre os analfabetos, $97 \%$ nunca utilizaram a Internet, proporção que atinge $60 \%$ entre os que estudaram até o Ensino Fundamental.

O uso da internet pelos respondentes apresentou uma distribuição entre diversas atividades, conforme o Gráfico 2, sendo a participação em redes sociais a que mais se destacou.

Gráfico 2 - Proporção de usuários de internet por atividade realizada percentual sobre o total de usuários de internet

\begin{tabular}{|l|l|}
\hline Participar de redes sociais, como Facebook, Orkut ou Google + & 77 \\
\hline Enviar mensagens instantâneas, por exemplo, por chat do Facebook, chat do Skype & 74 \\
\hline Enviar e receber e-mail & 72 \\
\hline Procurar informações sobre produtos e serviços & 65 \\
\hline Ouvir música on-line & 63 \\
\hline Compartilhar conteúdo na Internet, como textos, imagens ou vídeos & 60 \\
\hline Assistir filmes ou vídeos (em sites como o YouTube) & 56 \\
\hline Realizar atividades ou pesquisas escolares & 55 \\
\hline Baixar ou fazer o download de músicas & 50 \\
\hline
\end{tabular}




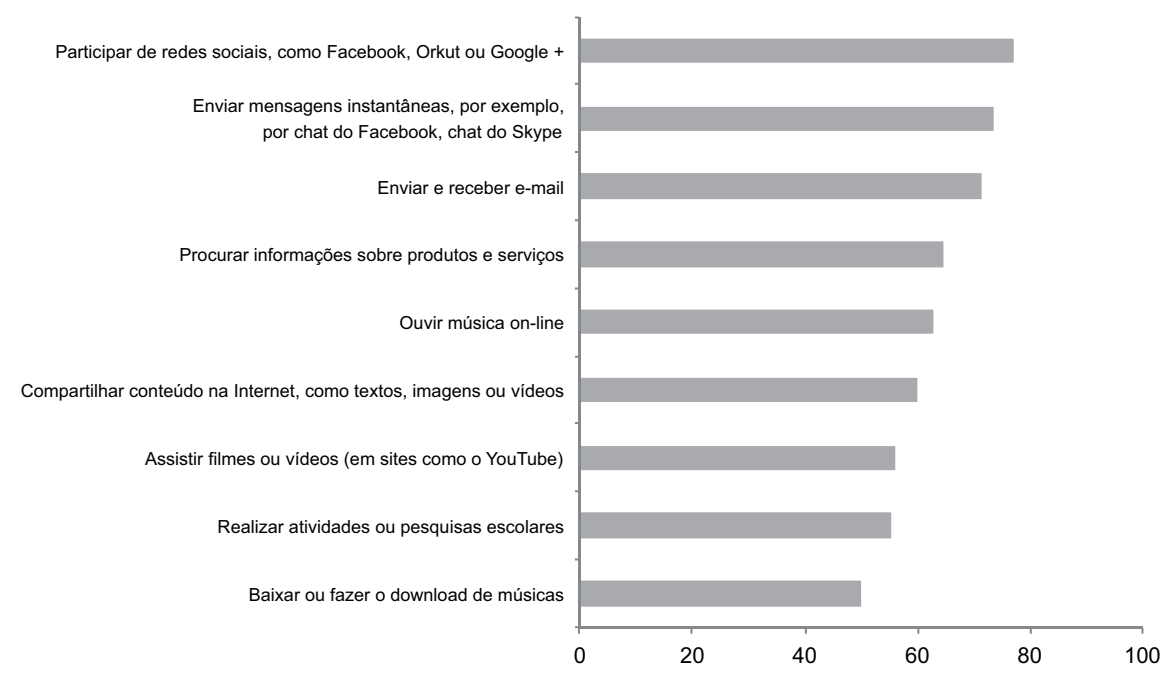

Fonte: CGI.br (2014).

Para analisar as atividades relacionadas ao governo eletrônico, a pesquisa TIC Domicílios considera os indivíduos com 16 anos de idade ou mais que utilizaram a internet nos três meses anteriores à entrevista, avaliando uma série de 22 tipos de serviços selecionados, relacionados a ações de busca de informação e transações realizadas. Os dados relativos a estes serviços estão na Tabela 1.

Em 2013, 68\% dos indivíduos declararam ter utilizado alguns dos serviços de governo eletrônico pesquisados. Segundo os dados coletados, os usuários que utilizam tais serviços com mais frequência possuem o Ensino Superior (86\%), têm idade entre 35 e 44 anos (74\%) e são pertencentes à classe A (87\%). Segundo o CGi (2014), a estivativa dos usuários de algum dos serviços de governo eletrônico pesquisados pela TIC Domicílios é de cerca de 48,4 milhões. 
Tabela 1 - Serviços de governo eletrônico utilizados

\begin{tabular}{|c|c|c|c|}
\hline \multirow{2}{*}{ SERVIÇOS UTILIZADOS } & \multicolumn{3}{|c|}{ \% POR ÁREA } \\
\hline & URBANA & RURAL & TOTAL \\
\hline \multicolumn{4}{|l|}{ 1. Obtenção de documentos } \\
\hline Consulta de CPF & 28 & 12 & 27 \\
\hline $\begin{array}{l}\text { Busca de informações sobre emissão de documentos } \\
\text { (RG, CPF, etc.) }\end{array}$ & 28 & 16 & 27 \\
\hline $\begin{array}{l}\text { Emissão de documentos (certificados, atestados, } \\
\text { comprovantes, etc.) }\end{array}$ & 18 & 14 & 18 \\
\hline $\begin{array}{l}\text { Obtenção de certidões negativas, licenças e } \\
\text { permissões }\end{array}$ & 16 & 06 & 15 \\
\hline \multicolumn{4}{|l|}{ 2. Pagamentos de taxas e impostos } \\
\hline Declaração de imposto de renda (inclusive isentos) & 20 & 12 & 20 \\
\hline Obtenção informação sobre impostos e taxas & 24 & 15 & 23 \\
\hline Pagamento de impostos, multas e taxas & 21 & 14 & 21 \\
\hline \multicolumn{4}{|l|}{ 3. Previdência e Assistência Social } \\
\hline $\begin{array}{l}\text { Busca de informações sobre Previdência Social e } \\
\text { benefícios sociais }\end{array}$ & 18 & 12 & 17 \\
\hline Solicitação de serviços junto à Previdência Social & ०9 & $\mathrm{O} 4$ & ०9 \\
\hline \multicolumn{4}{|l|}{ 4. Justiça e Segurança } \\
\hline Consulta de pontos na carteira de habilitação /multas & 17 & 13 & 17 \\
\hline Busca de informações sobre direito do consumidor & 20 & 12 & 19 \\
\hline $\begin{array}{l}\text { Consulta de andamento de atos processuais na } \\
\text { justiça }\end{array}$ & 12 & 05 & 12 \\
\hline Busca de informações sobre veículos roubados & 05 & 07 & 05 \\
\hline Boletim de ocorrência & 06 & $\mathrm{O} 2$ & o6 \\
\hline \multicolumn{4}{|l|}{ 5. Outros Serviços } \\
\hline $\begin{array}{l}\text { Busca de informações sobre serviços públicos de } \\
\text { educação }\end{array}$ & 25 & 23 & 25 \\
\hline Inscrição em concursos públicos & 24 & 14 & 23 \\
\hline Busca de informações sobre empregos & 18 & ०9 & 17 \\
\hline Busca de informações sobre direitos do trabalhador & 25 & 16 & 24 \\
\hline $\begin{array}{l}\text { Busca de informações sobre serviços públicos de } \\
\text { saúde }\end{array}$ & 21 & 14 & 21 \\
\hline
\end{tabular}




\begin{tabular}{|c|c|c|c|}
\hline Matrículas em escolas ou instituições de ensino & 10 & 08 & 10 \\
\hline Marcação e/ou agendamento de consultas médicas & 10 & 02 & 10 \\
\hline $\begin{array}{l}\text { Participação em fóruns, chats, votações etc. } \\
\text { relacionados ao governo }\end{array}$ & 08 & 05 & ०8 \\
\hline
\end{tabular}

Fonte: Elaborado pelos autores a partir de dados de CGI.br (2014).

Conforme dados constantes na Tabela 1, dos 22 serviços relacionados nenhum deles apresenta índice de utilização por pelo menos metade dos respondentes. Entre as atividades de governo eletrônico investigadas pela pesquisa TIC Domicílios 2013, em nível Brasil, considerando-se as áreas urbana e rural, a consulta ao Cadastro de Pessoa Física (CPF) foi realizada por $27 \%$ dos usuários. A busca de informações sobre emissão de documentos (RG, CPF, etc.) também obteve $27 \%$, e a busca de informações sobre serviços públicos de educação foi mencionada por $25 \%$. Já o pagamento de impostos, multas ou taxas foram feitos por $21 \%$ deles. Por outro lado, algumas atividades tiveram baixo índice de uso, tais como busca de informações sobre veículos roubados (5\%), fazer boletim de ocorrência (6\%) e participar de fóruns, chats e votações relacionados ao governo (8\%). Um ponto a se destacar é que os serviços que apresentaram maior índice de utilização são característicos ainda dos estágios 1 (presença emergente) e 2 (presença aprimorada) da classificação de níveis de maturidade proposta pelas Nações Unidas. (UNITED NATIONS, 200I) São serviços basicamente de obtenção de informações, com baixo nível de transações com interações efetivas entre usuários e Governo.

Segundo as pesquisas, o uso de serviços de governo eletrônico vem crescendo no período 2009-2013. Considerando aqueles que já utilizaram a internet pelo menos uma vez, 68\% usaram algum serviço durante 2013 , o que representa um aumento de $3 \%$ em relação a 2012 , e cerca de $152 \%$ em relação a 2009 (Tabela 2). Essa evolução, inclusive no que se refere aos dados específicos das áreas estudadas, pode ser visualizada no Gráfico 3. 
Tabela 2 - Proporção de indivíduos que usaram governo eletrônico no período 2009-2013

\begin{tabular}{|c|c|c|c|}
\hline \multicolumn{4}{|c|}{ \% EM RELAÇÃO AOS USUÁRIOS DE INTERNET } \\
\hline \multirow{2}{*}{ ANO } & \multicolumn{3}{|l|}{ ÁREA } \\
\hline & TOTAL & URBANA & RURAL \\
\hline 2009 & 27 & 30 & 10 \\
\hline 2010 & 23 & 26 & 07 \\
\hline 2011 & 31 & 34 & 10 \\
\hline 2012 & 65 & 66 & 50 \\
\hline 2013 & 68 & 69 & 52 \\
\hline
\end{tabular}

Fonte: elaborado pelos autores a partir de dados de CGI.br (2010, 2011, 2012, 2013, 2014).

Gráfico 3 - Uso de governo eletrônico no período 2009-2013 percentual em relação ao número de usuários de internet

\begin{tabular}{|l|l|l|l|}
\hline \multicolumn{4}{|l|}{ \% em relação aos usuários de internet } \\
\hline Ano & Total & Urbana & Rural \\
\hline 2009 & 27 & 30 & 10 \\
\hline 2010 & 23 & 26 & 7 \\
\hline 2011 & 31 & 34 & 10 \\
\hline 2012 & 65 & 66 & 50 \\
\hline 2013 & 68 & 69 & 52 \\
\hline
\end{tabular}

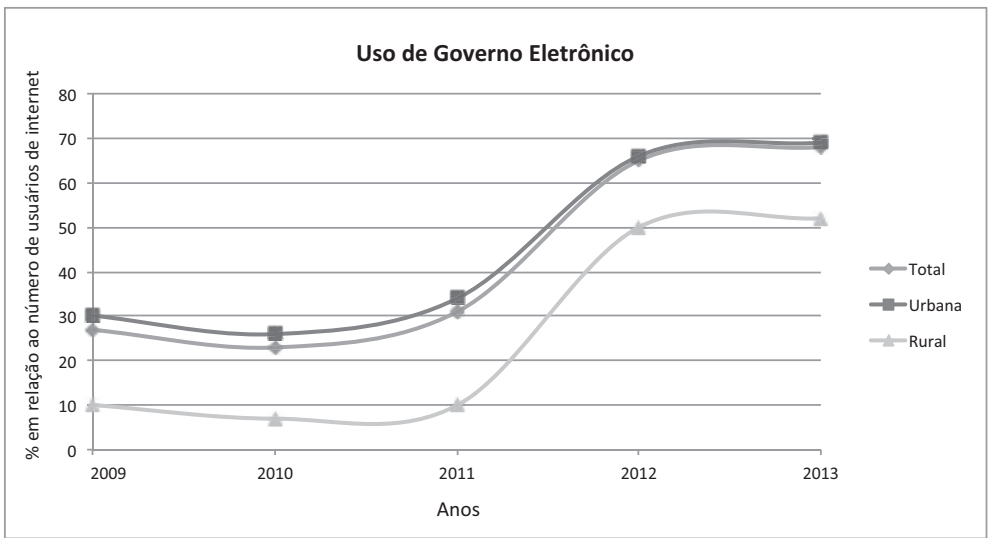

Fonte: elaborado pelos autores a partir de dados de CGI.br (2010, 2011, 2012, 2013, 2014). 
$\mathrm{Na}$ área urbana, 69\% dos indivíduos que acessam a internet em 2013 fizeram uso de serviços de governo eletrônico, enquanto que em 2009 esse percentual foi de $30 \%$, o que representa um aumento de $130 \%$. Na zona rural, houve também um aumento do uso, com uma diferença mais expressiva, passando de $10 \%$ em 2009 para $52 \%$ em 2013, atingindo um acréscimo de $420 \%$ no período. Salienta-se, no entanto, que o crescimento maior deu-se no período de 2011-2012. A Tabela 3 apresenta a evolução do uso dos serviços eletrônicos no período de 2009-2013.

Embora tenha havido um aumento na proporção de uso de governo eletrônico em geral no período 2009-2013, no que se refere aos serviços utilizados, estes apresentaram reduções de uso, algumas significativas: consulta de $\mathrm{CPF}$, de $49 \%$ para $27 \%$; declaração de imposto de renda, de $33 \%$ para $20 \%$; busca de informações sobre Previdência Social e benefícios sociais, de $22 \%$ para $17 \%$; busca de informações sobre serviços na área de educação, de $41 \%$ para $25 \%$; inscrição em concursos públicos, de 39\% para 23\%; busca de informações sobre empregos, de $33 \%$ para $17 \%$. Na direção oposta, o pagamento de impostos, multas e taxas sofreu um amuento, passando de $15 \%$ para $21 \%$.

Tabela 3 - Serviços de governo eletrônico utilizados

\begin{tabular}{lccccc}
\hline & \multicolumn{7}{l}{ \% EM RELAÇÃO AOS USUÁRIOS } \\
DE INTERNET & & & \\
& 2009 & 2010 & 2011 & 2012 & 2013 \\
\hline $\begin{array}{l}\text { 1. Obtenção de documentos } \\
\text { Consulta de CPF }\end{array}$ & 49 & 41 & 44 & 24 & 27 \\
$\begin{array}{l}\text { Busca de informações sobre emissão de } \\
\text { documentos (RG, CPF, etc.) }\end{array}$ & 29 & 29 & 34 & 21 & 27 \\
$\begin{array}{l}\text { Emissão de documentos (certificados, } \\
\text { atestados, comprovantes, etc.) }\end{array}$ & 21 & 16 & 26 & 13 & 18 \\
$\begin{array}{l}\text { Obtenção de certidões negativas, licenças e } \\
\text { permissões }\end{array}$ & 15 & 14 & 20 & 13 & 15 \\
\hline
\end{tabular}




\section{Pagamentos de taxas e impostos}

Declaração de imposto de renda (inclusive isentos)

33

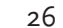

29

1920

Obtenção de informações sobre impostos

e taxas

27

22

26

16

Pagamento de impostos, multas e taxas

15

20

28

19

21

\section{Previdência e Assistência Social}

Busca de informações sobre Previdência

Social e benefícios sociais

24

19

24

15

17

Solicitação de serviços junto à Previdência Social

11

11

$14 \quad 08$

09

\section{Justiça e Segurança}

Consulta de pontos na carteira de habilitação /multas

21

19

$25 \quad 16$

Busca de informações sobre direito do consumidor

Consulta de andamento de atos processuais na justiça

$\begin{array}{lllll}13 & 12 & 18 & 11 & 12\end{array}$

Busca de informações sobre veículos roubados

$\begin{array}{lllll}09 & 05 & 07 & 05 & 05\end{array}$

Boletim de ocorrência

06

07

10

o6

06

\section{Outros Serviços}

Busca de informações sobre serviços públicos de educação

$\begin{array}{lllll}41 & 34 & 32 & 18 & 25 \\ 39 & 37 & 34 & 22 & 23 \\ 33 & 26 & 27 & 16 & 17\end{array}$

Busca de informações sobre empregos

Busca de informações sobre direitos do trabalhador

$\begin{array}{lllll}27 & 23 & 27 & 19 & 24\end{array}$

Busca de informações sobre serviços públicos de saúde

Matrículas em escolas ou instituições de ensino

$\begin{array}{lllll}14 & 12 & 14 & 08 & 10\end{array}$

Marcação e/ou agendamento de consultas médicas

Participação em fóruns, chats, votações etc. relacionados ao governo

$\begin{array}{lllll}09 & 07 & 10 & 06 & 08\end{array}$

Fonte: elaborado pelos autores a partir de dados de CGI.br (2010, 2011, 2012, 2013, 2014). 
Em relação à questão do não uso dos serviços eletrônicos, pesquisa TIC Domicílios 2013 revelou que 63\% dos não usuários de governo eletrônico apontam como motivo preferir fazer as consultas/contato pessoalmente. As características desses respondentes estão apresentadas no Gráfico 4. O não uso também está associado à dificuldade de encontrar os serviços ou até a própria complexidade inerente de alguns processos relativos aos serviços: $12 \%$ afirmam ser uma barreira a complicação para entrar em contato com a administração pública; $11 \%$ declararam que os serviços dos quais necessitavam não estavam disponíveis; e 14\% afirmam que os serviços desejados eram difíceis de serem encontrados. Um fato a destacar é que durante todo o período de 2009-2013, o item preferir fazer as consultas/contato pessoalmente mantem-se com nível alto de ocorrência (Tabela 4).

Gráfico 4 - Características dos não usuários de serviços de governo eletrônico

\begin{tabular}{|l|l|l|}
\hline \multicolumn{2}{|l|}{} & Prefiro fazer o contato pessoalmente \\
\hline \multirow{4}{*}{ TOTAL } & Sudeste & 63 \\
\hline \multirow{5}{*}{ Grau de instrução } & Nordeste & 67 \\
& Sul & 63 \\
& Norte & 59 \\
& Centro-Oeste & 49 \\
& Analfabeto / Educação infantil & 57 \\
\hline \multirow{5}{*}{ Faixa etária } & Fundamental & 71 \\
& Médio & 65 \\
& Superior & 62 \\
& De 16 a 24 anos & 60 \\
& De 25 a 34 anos & 63 \\
& De 35 a 44 anos & 67 \\
& De 45 a 59 anos & 68 \\
& 60 anos ou mais & 59 \\
\hline \multirow{5}{*}{ Classe social } & DE & 69 \\
& C & 63 \\
& B & 62 \\
& A & 56 \\
\hline \multirow{5}{*}{} &
\end{tabular}




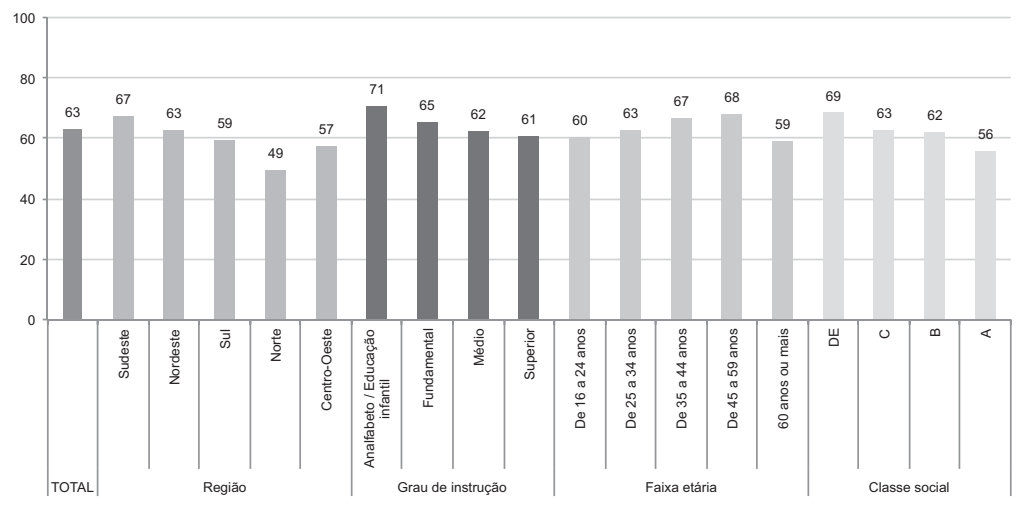

Fonte: CGI.br (2014).

Tabela 4 - Motivos para não uso de serviços de governo eletrônico

\begin{tabular}{|c|c|c|c|c|c|}
\hline \multirow{2}{*}{ MOTIVOS PARA NÃO UTILIZAÇÃO } & \multicolumn{5}{|c|}{$\begin{array}{l}\text { \% EM RELAÇÃO AOS USUÁRIOS DE } \\
\text { INTERNET }\end{array}$} \\
\hline & 2009 & 2010 & 2011 & 2012 & 2013 \\
\hline Prefere fazer o contato pessoalmente & 56 & 46 & 69 & 64 & 63 \\
\hline Serviços são difíceis de encontrar & 08 & 12 & 10 & 12 & 14 \\
\hline $\begin{array}{l}\text { Preocupação com a proteção e segurança } \\
\text { dos dados }\end{array}$ & 15 & 14 & 16 & 18 & 14 \\
\hline $\begin{array}{l}\text { Uso da internet para contato com a } \\
\text { administração pública é complicado }\end{array}$ & 12 & ०9 & 11 & 13 & 12 \\
\hline Serviços desejados não estão disponíveis & ०9 & 11 & 07 & 12 & 11 \\
\hline $\begin{array}{l}\text { Dificuldade em receber retorno às } \\
\text { solicitações }\end{array}$ & 03 & 03 & 04 & ০8 & 09 \\
\hline $\begin{array}{l}\text { Serviços estão disponíveis. mas não é } \\
\text { possível completar a transação }\end{array}$ & $\mathrm{O} 2$ & $\mathrm{O} 2$ & 05 & 05 & 04 \\
\hline Não sabe / não respondeu & ०8 & 13 & 12 & 07 & $\mathrm{O} 2$ \\
\hline Outros motivos & 13 & 19 & - & - & - \\
\hline
\end{tabular}

Fonte: elaborado pelos autores a partir de dados de CGI.br (2010, 2011, 2012, 2013, 2014). 
Embora a disponibilidade de acesso via banda larga seja restrito ou inexistente em várias regiões, o custo do acesso com qualidade e velocidade à internet tem baixado, principalmente via rede de telefonia celular, o que tem contribuído para o aumento de usuários e, consequentemente, há um grande potencial para o uso dos serviços de governo eletrônico. No entanto, as questões segurança e privacidade ainda são consideradas fatores para não usá-los.

Ainda pode-se apontar como fatores restritivos ao uso a falta de conhecimento da disponibilidade dos serviços e da habilidade do uso por parte dos usuários, aspectos relacionados em parte com o nível de escolaridade e/ou condição socioeconômica e, consequentemente, dos processos de exclusão digital. Há, também, problemas decorrentes dos níveis de maturidade dos serviços (grau de execução das transações), na sua maioria apenas informacionais, não permitindo transações completas como, por exemplo, apuração e pagamento de impostos ou taxas. Também alguns serviços não estão disponíveis ou são difíceis de serem encontrados e, em alguns casos, existe uma demora ou inexistência do atendimento às solicitações dos usuários, o que é apontado pela pesquisa como motivos para o não uso dos serviços.

Para Santos e Reinhrad (2012), um fator que torna crítica a implementação dos serviços eletrônicos no Barsil é que o sistema de divisão de poderes no país se apresenta em três níveis verticais (federal, estadual e municipal), e cada um deles com divisões funcionais (executiva, legislativa e judicial). Com isto, oferecer serviços, principalmente àqueles que necessitam da integração entre os órgãos envolvidos, torna-se um processo complexo.

\section{CONSIDERAÇÕES FINAIS}

Este estudo teve como objetivo avaliar de forma exploratória o uso e as motivações do não uso de serviços de governo eletrônico no Brasil. Os dados apresentados pela pesquisa TIC Domicílios evidenciam um crescimento do acesso e uso da internet, mas sem o correlato incremento do uso dos serviços de governo eletrônico. 
Adicionalmente, foi constatado que existem vários motivos pelos quais os serviços não são usados o que indica a necessidade do estabelecimento de ações específicas para a redução desses limitadores, tais como a baixa capilaridade da infraestrutura de comunicações fora dos grandes centros, o custo do acesso à internet de alta velocidade e, principalmente, a resistência dos usuários, que ainda preferem, em sua maioria, obter os serviços e/ou informações presencialmente.

Como sugestão de pesquisas futuras, indica-se uma análise mais aprofundada sobre a ausência de correlação entre o aumento do uso de internet e o de serviços eletrônicos, e também uma exploração sobre a influência das características socioeconômicas e demográficas no uso destes serviços.

\section{REFERÊNCIAS}

AVGEROU, C. et al. The role of information and communication technology in building trust in governance: toward effectiveness and results. Washington, D.C.: Inter-American Development Bank, 2005.

BAUM, C.; DI MAIO, A. Gartner's four phases of e-government model. Stanford: Gartner Group, 2000. (Research Note)

BENT, S.; KERNAGHAN, K.; MARSON, D. Innovations and good practices in single-window service. Ottawa: Canadian Centre for Management Development, 1999.

CIBORRA, C.; NAVARRA, D. Good governance and development aid: risks and challenges of e-government in Jordan. In: KORPELA, M.; MONTEALEGRE, R.; POULYMENAKOU, A. Organizational Information Systems in the Context of Globalization. Dordrecht: Kluwer, 2003.

CGI.br. Pesquisa sobre o uso das tecnologias da informação e da comunicação no Brasil 2009: TIC domicílios e TIC empresas. São Paulo: Comitê Gestor da Internet no Brasil, 2010.

CGI.br. Pesquisa sobre o uso das tecnologias da informação e da comunicação no Brasil 2010: TIC domicílios e TIC empresas. São Paulo: Comitê Gestor da Internet no Brasil, 2011. 
CGI.br. Pesquisa sobre o uso das tecnologias da informação e da comunicação no Brasil 2011: TIC domicílios e TIC empresas. São Paulo: Comitê Gestor da Internet no Brasil, 2012.

CGI.br. Pesquisa sobre o uso das tecnologias da informação e da comunicação no Brasil 2012: TIC domicílios e TIC empresas. São Paulo: Comitê Gestor da Internet no Brasil, 2013.

CGI.br. Pesquisa sobre o uso das tecnologias da informação e da comunicação no Brasil 2012: TIC domicílios e TIC empresas. São Paulo: Comitê Gestor da Internet no Brasil, 2014.

CRIADO, J.; RAMILO, M. e-Administración: ¿un Reto o una Nueva Moda para las Administraciones del Siglo XXI? Algunos Problemas y Perspectivas de Futuro en torno a Internet y las Tecnologías de la Información y la Comunicación en las Administraciones Públicas. Revista Vasca de Administración Pública, v. 61, n. 1, p. 11-43, 2001.

DELOITTE; TOUCHE. The citizen as customer. CMA Management, v. 74 , n. 10, p. 58, Dec./Jan., 2000/2001.

EUROPEAN PUBLIC ADMINISTRATION NETWORK. Key principles of an interoperability architecture. Ireland, 2004.

FLAK, L. S.; SEIN M. K.; SÆB $\varnothing, ~ Ø$. Towards a cumulative tradition in e-government research: Going beyond the Gs and Cs. In: WIMMER, M. A.; SCHOLL, H. J.; GRÖNLUND, Å. (Ed.). EGOV 2007, LNCS 4656. Berlin: Springer-Verlag, 2007. p. 13-22.

GRANDE, J.; ARAUJO, M.; SERNA, M. La necesidad de teoría(s) sobre gobierno electrónico: uma propuesta integradora. In: CONCURSO DE ENSAYOS Y MONOGRAFÍAS DEL CLAD SOBRE REFORMA DEL ESTADO Y MODERNIZACIÓN DE LA ADMINISTRACIÓN PÚBLICA, 16., 2002, Caracas. Anais eletrônicos... Caracas: Centro Latinoamericano de Administración para el Desarollo, 2002.

HAGEN, M; KUBICEK, H. One-stop-government in Europe: results of 11 national surveys. Bremen: University of Bremen, 2000.

HILLER, J. S.; BÉLANGER, F. Privacy strategies for electronic government. In: ABRAMSON, M. A.; MEANS, G. E. (Ed.). E-government 2001. Lanham, MD: Rowman \& Littlefield Publishers, 200I. p. I62-I98. 
HOFFMAN, D.; NOVAK, T. P.; PERALTA, M. Building Consumer Trust Online. Communications of the ACM, v. 42, n. 4, p. 80-85, 1999.

IBGE. Censo Demográfico 2000. Disponível em: <http://www.sidra.ibge. gov.br>.

IBGE. Censo Demográfico 2010. Disponível em: <http://www.sidra.ibge. gov.br/>.

IBGE. Pesquisa Nacional por Amostra de Domicílios (PNAD). Disponível em< http://www.sidra.ibge.gov.br/pnad/default.asp $\geq$.

INTERNATIONAL TELECOMMUNICATION UNION. Manual for Measuring ICT Acess and Use by Households and Individuals - 2014 edition. Disponível em: <http://www.itu.int/dms_pub/itu-d/opb/ind/D-INDITCMEAS-2014-PDF-E.pdf>. Acesso em: 20 dez 2014.

INTOSAI. Auditing E-government. Viena: Intosai, Standing Committee on IT Audit, Task Force for Auditing E-Government, 2003.

JANSSEN, M.; CRESSWELL, A. An enterprise application integration methodology for e-government. Journal of Enterprise Information Management, v. 18, n. 5, p. 537-547, 2005.

KAMAL, M.; WEERAKKODY, V.; IRANI, Z. Analyzing the role of stakeholders in the adoption of technology integration solutions in UK local government: An exploratory study. Government Information Quarterly, v. 28, n. 2, p. 200-210, 2011.

LAYNE, K.; LEE, J. Developing fully functional e-government: a four stage model. Government Information Quarterly, v. 18, n. 2, p. 12-136, 2001.

LEE, J.; KIM, H. J.; AHN, M. J. The willingness of e-Government service adoption by business users: The role of offline service quality and trust in technology. Government Information Quarterly, v. 28, n. 2, p. 222-230, Apr. 2011.

MOON, M. The evolution of e-government among municipalities: rhetoric or reality? Public Administration Review, v. 62, n. 4, p. 424-433, July/Aug. 2002.

NATIONAL AUDIT OFFICE. Better public services through e-government. Londres: The Stationery Office, 2002. 
OECD. E-government: analysis framework and methodology. Paris:

OCDE, 2001.

OKOT-UMA, R. Electronic governance: re-inventing good governance. Londres: Commonwealth Secretariat London, 2001.

OLIVEIRA, C. Governo na era da informação: o caso do portal Bahia.gov. Lauro de Freitas: UNEB, 2003.

SANTOS, E. M.; REINHARD, N. Disponibilização e uso de serviços de governo eletrônico no Brasil: a visão dos usuários. In: PINHO, J. A. G. de. (Org.). Estado, sociedade e interações digitais: expectativas democráticas. Salvador: EDUFBA, 2012. p. 119-136.

SIAU, K.; LONG, Y. Innovations through information technology. Hershey: Idea Group, 2004.

SWID, A. A.; ELMELEGY, A. R. Management of e-services adoption in the telecommunications sector in Bahrain. Journal of Global Business and Technology, v. 8, n. 2, Fall, 2012.

TRANMÜLLER, R.; WIMMER, M. Processes - collaboration - norms - knowledge: Signposts for administrative application development. In: INTERNATIONAL WORKSHOP ON DATABASE AND EXPERT SYSTEMS APPLICATIONS, 11., 2000. Greenwich, UK. Proceedings... Los Alamitos: IEEE Computer Society, 2000. p. 1141-1145.

UNITED NATIONS. Global survey of e-Government. Nova York: United Nations; Division for Public Economics and Public Administration: American Society for Public Administration, 2001.

WORLD BANK. A definition of e-Government. World Bank's E-government Website. 2003. Disponível em: <http://www1.worldbank. org/publicsector/egov/definition.htm>. Acesso em: 16 jul. 2014. 


\section{SOBRE OS AUTORES}

Ana Cláudia Farranha possui graduação em Direito pela Universidade Federal do Espírito Santo (1991), mestrado em Ciência Política pela Universidade Estadual de Campinas (1999) e doutorado em Ciências Sociais pela Universidade Estadual de Campinas (2006). É professora adjunta da Faculdade de Direito da Universidade de Brasília (UnB), desenvolvendo atividades na área de Direito e Gestão Pública. É pesquisadora do Centro Interdisciplinar de Estudos do Transporte da UnB, professora Programa de Pós-Graduação em Transporte da UnB e do Programa de Pós-Graduação em Direito da UnB. Coordena a pesquisa Administração Pública e Redes Sociais, financiada com recursos do CNPq. Tem experiência na área de Ciência Política e Direito, atuando principalmente nos seguintes temas: Estado, marco regulatório e políticas públicas; pobreza, poder político, poder e desenvolvimento local; gênero e raça e direitos humanos e temas relacionados com a promoção da equidade e avaliação de políticas públicas

Cecília Bruscoli es Técnica Superior en Comunicación Social, con orientación en Investigación y Planeamiento de la Escuela de Ciencias de la Información (Universidad Nacional de Córdoba). Desde 2013 participa en equipos de investigación acreditados y subsidiados por la Secretaria de Ciencia y Tecnica de la UNC junto a la Dra. Corina Echavarría. Trabaja en La Lumière Escuela de Cine y Fotografía y, actualmente, se desempeña en los equipos de Unicef Argentina que trabajan junto al gobierno de la provincia de Córdoba. 
Corina Echavarría es Licenciada en Ciencia Política (UCC, 1995), Magister en Administración Pública (Instituto de Investigación y Formación en Administración Pública, Universidad Nacional de Córdoba, 2000), Doctora en Administración por el Nucleo de Pósgraduacao em Administracao (Universidade Federal da Bahia, 2005). Investigadora Asistente del CONICET en el Centro de Investigaciones y Estudio sobre Cultura y Sociedad (CIECS-CONICET y UNC), Profesora Adjunta del Instituto de Investigación y Formación en Administración Pública (UNC), en el área Desarrollo Local, y Directora del Programa "Problemáticas comunicacionales barriales, organizacionales y políticas. Experiencias de lucha y resistencia a comienzos de siglo XXI en la provincia de Córdoba" (CIECS y SeCyT/UNC). Líneas de investigación actuales incluyen problemas de legitimación democrática del gobierno y la administración pública, con énfasis en la democracia deliberativa y la participación ciudadana. Profesora-adjunta de la Facultad de Ciencia Política y Relaciones Internacionales (Universidad Católica de Córdoba) y profesora-asistente da Escuela de Ciencias de la Información (UNC). Se ha desempeñado como consultora para UNIFEM en las temáticas de ciudades inclusivas y género y presupuestos sensibles al género. Desarrolla actividades de extensión y transferencia en el Grupo Temático Democracia Participativa de la Red Ciudadana Nuestra Córdoba. Cuenta con diversas publicaciones a nivel nacional e internacional e integra redes internacionales de cooperación académica que ponen de relieve la problemática de la gestión urbana democrática.

Eduardo Henrique Diniz é engenheiro eletrônico, mestre e doutor em Administração de Empresas pela Fundação Getúlio Vargas (FGV-EAESP), com ênfase em Sistemas de Informação Gerencial. Visiting Scholar na Universidade da Califórnia, Berkeley de 1996 a 1998, e da HEC Montreal em 2007. Professor da FGV-EAESP, São Paulo, desde 1999. Membro do Centro de Estudos de Inclusão Financeira e Microfinanças da FGV. Tem pesquisado em tecnologia no setor bancário e de governo desde 1991 e publicou vários artigos e livros sobre esses temas. Editor-chefe da Revista Brasileira de Administração de Empresas desde 2009 . 
Ernani Marques dos Santos é professor adjunto da Escola de Administração da Universidade Federal da Bahia (UFBA). Mestre em Administração pela UFBA e doutor em Administração pela Universidade de São Paulo (USP). Foi Visiting Researcher na London School of Economics and Political Science e realizou pesquisas de pós-doutoramento na Faculdade de Economia, Administração e Contabilidade da USP. É vice-coordenador do Núcleo de Pesquisa em Internet, Democracia, Estado e Sociedade, pertencente ao Núcleo de Pós-Graduação em Administração da Escola de Administração da UFBA. Sua principal área de interesse de pesquisa compreende a adoção de tecnologias e sistemas de informação nas dimensões individual e organizacional, com especial ênfase no setor público.

Fabiano Maury Raupp possui graduação em Ciências Contábeis (2001) e mestrado em Administração (2003), ambos pela Universidade Federal de Santa Catarina e doutorado em Administração pela Universidade Federal da Bahia (2011). Professor e pesquisador do Departamento de Administração Empresarial (DAE) e do mestrado acadêmico em Administração do Centro de Ciências da Administração e Socioeconômicas, Universidade do Estado de Santa Catarina.

Ingrid Winkler é doutora em Administração pela Universidade Federal da Bahia (UFBA), em colaboração com a Ecole des Hautes Etudes Commerciales - HEC Montreal. Atualmente é Gerente de Desenvolvimento de Software no Senai Cimatec, onde também atua como docente. Tem experiência de docência na graduação e pós-graduação da UFBA, Universidade Católica de Salvador, Universidade de Salvador e Faculdade Ruy Barbosa. Tem como interesses de pesquisa temas como Impacto Social da Tecnologia e Software para Educação e Saúde. É cofundadora e atual conselheira da organização não-governamental Instituto Fazer Acontecer, que desde 2004 promove atividades socioeducativas para adolescentes de comunidades de baixa renda de Salvador.

José Antonio Gomes de Pinho possui graduação em Engenharia pela Universidade Estadual Paulista Júlio Mesquita Filho (1973), mestrado em Planejamento Urbano e Regional pela Universidade Federal do Rio 
de Janeiro (1978) e doutorado em Regional Planning pela LSE - University of London (1986). Professor Titular da Universidade Federal da Bahia. Foi editor da revista Organizações \& Sociedade (O\&S) de 1997 a 2013. Leciona na área de Ciência Política, com ênfase em Estado e Sociedade. Tem realizado pesquisa nas áreas de governo eletrônico, democracia digital, sociedade da informação/internet, corrupção, governo local, futebol. Coordenador do NIDES: Núcleo de Internet, Democracia, Estado e Sociedade registrado no CNPq.

Júlio César Andrade de Abreu é mestre e doutor em Administração pela Escola de Administração da Universidade Federal da Bahia (UFBA). Professor adjunto da Universidade Federal Fluminense, atua no Programa de pós-graduação em Administração e no Laboratório multidisciplinar em pesquisas sobre trabalho, organizações e sociedade. É membro do NIDES: Núcleo de Internet, Democracia, Estado e Sociedade. Temas de interesse: participação digital; democracia eletrônica; orçamento participativo e tecnologias sociais.

Jussara Borges é professora adjunta do Instituto de Ciência da Informação da Universidade Federal da Bahia (UFBA). Mestre em Ciência da Informação e doutora em Comunicação e Cultura Contemporâneas pela Facom-UFBA. Tem publicado regularmente textos em revistas e livros, com ênfase em participação política, competências digitais, inclusão digital e governo eletrônico.

Leila Lage Humes é pós-doutoranda da Faculdade de Economia, Administração e Contabilidade da Universidade de São Paulo (FEA/USP), e Engenheira Civil pela Escola Politécnica da Universidade de São Paulo (POLI/USP), mestre e doutora em Administração pela FEA/USP. Atualmente é assessora da Superintendência de Tecnologia de Informação da USP e pesquisadora na área de sistemas de informação e informática pública.

Maíra Ouríveis do Espírito Santo é graduada em Relações Internacionais pela Universidade Estadual Paulista Júlio Mesquita Filho (2010) e mestre em Ciências Sociais pela mesma universidade (2014). Ana- 
lista de informações do Centro Regional de Estudos para o Desenvolvimento da Sociedade da Informação, ligado ao Núcleo de Informação e Coordenação do Ponto BR. Tem experiência nas áreas de Sociologia, Relações Internacionais e Tecnologias da Informação e Comunicação.

Manuella Maia Ribeiro é doutoranda e mestre em Administração Pública e Governo, pela Fundação Getúlio Vargas. Bacharel em Gestão de Políticas Públicas, pela Universidade de São Paulo e Direito, pela Universidade Presbiteriana Mackenzie. Analista de informações do Centro Regional de Estudos para o Desenvolvimento da Sociedade da Informação, ligado ao Núcleo de Informação e Coordenação do Ponto BR.

Marco Antônio Carvalho Teixeira é graduado em Ciências Sociais pela Pontifícia Universidade Católica de São Paulo (1996) onde também obteve os títulos de mestre (1999) e doutor (2004), também em Ciências Sociais, na área de concentração em Ciência Política. Atualmente é professor extra-carreira do Departamento de Gestão Pública (GEP) da Escola de Administração de Empresas da FGV-SP, onde leciona nos cursos de graduação em Administração de Empresas e Administração Pública, mestrado e doutorado em Administração Pública e Governo e mestrado profissional em Gestão e Políticas Públicas. Também é professor do curso de Relações Internacionais da Fundação Santo André e colaborador da ONG Oficina Municipal e da FUNDAP. Desenvolve pesquisas sobre governos locais em questões como: democracia e participação social, relações executivo e legislativo, desenvolvimento socioeconômico local, bem como qualidade de vida e políticas públicas. No momento, está envolvido em pesquisas acerca do papel de instituições como o Tribunal de Contas da União e a Controladoria Geral da União, na promoção da accountability horizontal, no âmbito das instituições de controle da administração pública brasileira. As atividades de pesquisa estão vinculadas ao Centro de Estudos em Administração Pública e Governo e ao Departamento de Gestão Pública, ambos da Fundação Getúlio Vargas.

Maria Alexandra Cunha é graduada em Administração (1987) e Informática (1982) pela Universidade Federal do Paraná, tem mes- 
trado em Administração de Empresas pela Fundação Getúlio Vargas (1994) e doutorado em Administração pela Universidade de São Paulo (2000). É professora da Escola de Administração de Empresas de São Paulo e leciona nos cursos de Administração de Empresas e Administração Pública, mestrado e doutorado em Administração de Empresas e mestrado profissional em Gestão e Políticas Públicas. Foi coordenadora da divisão ADI da Associação Nacional de Pós-Graduação e Pesquisa em Administração por 4 anos. Tem experiência na área de Administração, com ênfase em Organizações Públicas, atuando principalmente nos seguintes temas: governo eletrônico, informática pública, sociedade da informação, administração pública e gestão de tecnologia da informação.

Maria Camila Florêncio da Silva é doutoranda do Programa de Administração Pública e Governo da Escola de Administração de Empresas da Fundação Getúlio Vargas (FGV-EAESP) (início em 2014). Mestra em Direito pela Escola de Direito de São Paulo da FGV (2012-2014). Possui Bacharelado em Direito pela Universidade Católica de Pernambuco (2011). Integra o Centro de Estudos de Administração Publica e Governo da EAESP; o Núcleo de Pesquisa Democracia e Ação Coletiva do Centro Brasileiro de Análise e Planejamento e o Núcleo de Pesquisas em Gênero e Masculinidades da Pós-Graduação de Psicologia da Universidade Federal de Pernambuco.

Nicolau Reinhard é professor titular, livre docente e doutor em Administração de Empresas pela Faculdade de Economia, Administração e Contabilidade da Universidade de São Paulo (FEA/USP), e engenheiro mecânico, opção Produção pela Escola Politécnica da Universidade de São Paulo. Realizou pós-doutorado na A. P. Sloan School of Management do Massachussetts Institute of Technology. É professor de Informática e Sistemas de Informações do Departamento de Administração da FEA/USP desde 1969, pesquisador na área de sistemas de informação e informática pública e autor de vários trabalhos científicos publicados no Brasil e no exterior. 
Othon Jambeiro Graduado em Jornalismo na Universidade Federal da Bahia (UFBA), mestre em Ciências Sociais pela Universidade de São Paulo, doutor em Comunicação pela University of Westminster, com pós-doutorado em Comunicação pela Universidade de Brasília. É pesquisador 1-B do sistema CNPq, dedicando-se a investigações de políticas e economia política de informação e comunicação. Publicou cerca de 70 artigos ou capítulos de livros, alguns em revistas acadêmicas internacionais. Entre os livros que publicou e/ou organizou contam-se 12 títulos, todos resultados de trabalhos de natureza acadêmica. Coordenou dois programas internacionais de pesquisa: um, com investigadores da Universidade de Aveiro, Portugal, por quatro anos, voltado para estudos de concepção e estratégias de educação à distância; e outro, com pesquisadores da Universidade do Texas, também por quatro anos, voltado para estudos de políticas de comunicações, inclusão digital e jornalismo on-line. É professor do quadro permanente do Programa de Pós-Graduação em Comunicação e Cultura Contemporâneas, da UFBA.

Stefania Lapolla Cantoni é mestranda em Ciência Política pela Universidade de São Paulo e formada em Ciência Política pela Universidad Nacional de Entre Ríos (Argentina). Concentra seus estudos na participação política, especialmente nos seus condicionantes e motivações. Atualmente participa do Projeto de Pesquisa Democracia Digital da Fundação Getúlio Vargas.

Taiane Ritta Coelho é doutoranda e pesquisadora da Escola de Administração de Empresas de São Paulo da Fundação Getúlio Vargas (FGV-EAESP). Mestre em Administração pela Universidade Federal do Paraná (UFPR). Participa de projetos de pesquisas concentrados em Tecnologias da Informação e Comunicação (TIC), Inovação, Democracia Digital e Governo e é integrante do Centro de Estudos em Administração Pública e Governo da FGV. Seus interesses de pesquisa incluem e-government, e-participação, transparência, dados governamentais abertos e TIC para o desenvolvimento. 


\title{
COLOFÃo
}

\author{
Formato $17 \times 24 \mathrm{~cm}$ \\ Tipografia Scala/ ScalaSansPro \\ Papel Alcalino $75 \mathrm{~g} / \mathrm{m}^{2}$ (miolo) \\ Cartão Supremo $300 \mathrm{~g} / \mathrm{m}^{2}$ (capa) \\ Impressão Edufba \\ Capa e Acabamento Cian Gráfica \\ Tiragem $\quad 400$ exemplares
}

